\title{
COMMON UNITY
}

RECONNECTING PEOPLE WITH THE ENVIRONMENT THROUGH INDIGENOUS VALUES

AND PARTICIPATORY DESIGN

BY FETU ESE 


\section{DEDICATION}

This thesis is dedicated to the Ngāti Toa Rangatira iwi and the people of

Takapūwāhia community. May the core values of Ngāti Toa Rangatira provide

the platform to a strong and united community. 


\section{PĒPEHA}

TẼNĀ KOUTOU KATOA

KO WHITIREIA TE MAUNGA

KO RAUKAWA TE MOANA

KO TAINUI TE WAKA

KO NGĀTI TOA RANGATIRA TE IWI

KO TAKAPŪWĀHIA TE MARAE

KO ESE TŌKU WHĀNAU

KO FETU TŌKU INGOA

NGĀ MIHI NUI KI A KOUTOU

\section{ETHICS APPROVAL}

Research Ethics approval was obtained from Victoria University of

Wellington Human Ethics Committee in order to conduct this thesis.

APPROVAL N0.0000027627

A 120-point thesis

submitted to the Victoria University of Wellington in partial fulfilment of

the requirements for the degree of Master of Landscape Architecture

Victoria University of Wellington

School of Architecture

2020 


\section{ABSTRACT}

\section{ACKNOWLEDGEMENTS}

Firstly, I would like to acknowledge my family for their never-ending love, support and encouragement to strive forward and achieve my goals in life.

To my Archi friends who have shared this journey with me. Thank you for the support, inspiration and mental stability through vigorous long nights and unexpected challenges. We have created life long friendships and memories I will forever cheris

To my Ngāti Toa people and community. Thank you for allowing me to tell the story of our people and inspiring me to reconnect with our culture and our values.

To my supervisors Maria and Bruno. Thank you for dedicating your time and effort to help me achieve my goals in the field of Landscape Architecture.

To the NZ Rugby Foundation. Thank you for all the support and encouragement to push on with life through all the challenges. You have allowed me to strive for great things and achieve things I once considered unachievable.

Lastly, I would like to acknowledge everyone who has had a positive impact in my life and influenced me to better not only myself but also others.

THANK YOU!
A significant problem for struggling communities in New Zealand is disconnection from the environment and a loss of cultural values. These issues cause disengagement and division between the people and the environment. Social stability gradually declines, leading to participation within one's community being discouraged. Investigations into community engagement and the enhancement of the community environment suggest there has been a failure to address the current issues affecting struggling communities. Disconnect and disregard for Indigenous values in communities prove to be a defining factor in the relationship between people and the environment. Indigenous Māori incorporated Mātauranga (knowledge), Tikanga (customs) and Māori values in their way of life which proved instrumental in their development and sense of Kotahitanga (unity) between themselves and with the environment. This allowed Māori to become one with the land and for Whanaungatanga (sense of belonging) and Kaitiakitanga (guardianship of the land) to spread through the people. However, these values have been compromised and subsequently lost due to the European influence on the land and on Măori people. There needs to be a vigorous search for answers on how to reconnect people with these values so as to build strong and united communities.

This design research looks at ways of enhancing the struggling community of Takapūwāhia, Porirua, and the local iwi, Ngāti Toa. It seeks to address problems of disconnect, disengagement and loss of values

between the environment and the people. This research aims to answer the research question 'How can we unite a community by implementing Indigenous values when designing for people?' The first step will be to undertake a literature review and evaluation of various case studies relevant to the research question Then community engagement will take place so people can come together to evaluate existing problems and to enable the voice and vision of the people to influence the final design outcome. Effective methods of community engagement will be employed through Participatory and Consultative Design which will provide ways of communicating ideas and solutions.

Design experiments will be carried out on the identified problem degraded sites within the Takapūwāhia community. These will be presented back to the community with participation with other community members in the design process, contributing to community growth and identity.

With the key objective of the research being to unite the Takapūwāhia community, this will be achieved through their voice and their vision being integral to the design outcome, which will portray a story unique to the people of Ngāti Toa and to Takapūwāhia, exploring Māori symbolism essential to Ngāti Toa and integrating Mãori values with Landscape Architecture. This will connect people to the design, this particular place and to the environment and help achieve the goal of the project of creating a sense of unity, ownership and belonging, of Kotahitanga, Whanaungatanga and Kaitiakitanga. 


\section{CONTENTS}

INTRODUCTION

Problem Statement

Research Proposal

Methodology

LITERATURE REVIEW

Introduction

Indigenous Values

Community Engagement

Participatory Design

Reconnection to Place

SITE CONTEXT

Porirua Geography

History

History of Takapūwāhia

Takapūwāhia Context

CASE STUDIES

Case Study 1

Case Study 2

Case Study 3

Case Study 4

Case Study 5

\section{DESIGN FRAMEWORK}

Design Proposal

Participatory Design

DESIGN EXPLORATION

Design Ideas

Symbolism

Green Street Design

Te Hiko Street Wetland Park

Consultative Design

DEVELOPED DESIGN

Green Street Design

Te Hiko Wetland Park

CRITICAL REFLECTION

Reflection

Conclusion

REFERENCES

References

Figure References 


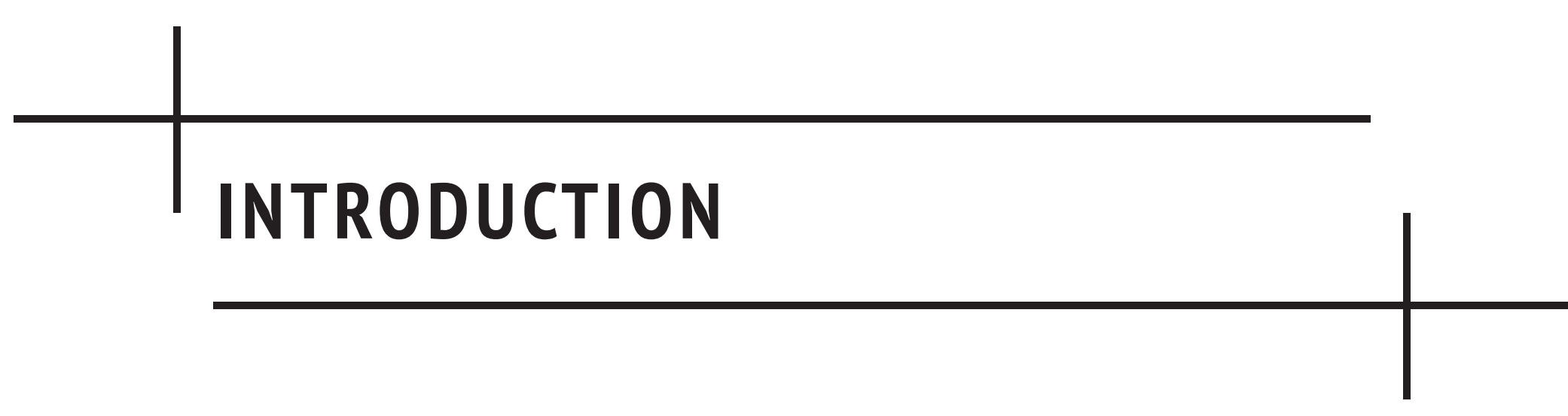




\section{Problem Statement}

From the first European migration to New Zealand (Aotearoa), up until the present day, there has been a considerable increase in Western influence exerted on the Indigenous

Mãori people and on the environment.

This influence has seen a cultural shift

from the Indigenous Māori culture to a

predominantly Western culture. This shift

has led to disconnection between Māori

people and the values their culture is built

on. Māori people displayed their cultural

values through Mātauranga Māori (Māori

Knowledge) and Tikanga Māori (Māori Way).

Values such as Whanaungatanga (sense of

belonging),Whakapapa (genealogy) and

Kaitiakitanga (guarding our natural treasures)

were compromised when Europeans asserted

their dominance on the land and the people.

This challenged the values Māori had for the

land and their people, and they were forced to

adopt and adapt to Western culture.

The manipulation and change Europeans exercised on the landscape was for economic gain and to create scenery they saw as

aesthetically pleasing. This was largely without understanding and appreciation of the existing natural environment and has led to a decline in natural ecosystems and to disconnect between the people and the land.
Development of land and infrastructure such as roads and pipes replaced natural streams, wetlands and native vegetation. These were vital aspects of the environment which accommodated native species of flora and fauna in New Zealand.

In the case of Porirua, located in the lower North Island, there is evidence of the massive impact of colonisation and this is particularly apparent in the Porirua Harbour. The harbour was once the platform on which the local iwi Ngāti Toa built their Māori values. This iwi relied on the harbour for its abundant resources which gave sustenance to their people. These resources provided the Ngāti Toa people with the tools to practice traditional methods that portrayed their cultural values and ways. These practices enabled them to live off the land and utilise the rich resources the area provided. They passed on their knowledge of Mātauranga and Tikanga Māori values

through Mōhiotanga (sharing of information) and becoming guardians of the land with the process and practice of protecting and looking after the environment (Kaitiakitanga). These traditions have since been challenged, with the Western culture heavily influencing change to the natural environment and the people. 
These changes have seen the harbour become degraded and caused interruption to the natural ecosystems that once thrived in and around the Porirua Harbour catchment. Without

the resources and practices the harbour provided, traditional Māori values began to fade.

Porirua Harbour holds great significance to the Ngāti Toa iwi because it was the focal point for their people. Ngāti Toa's great chief and leader Te Rauparaha led his people from Kawhia to Porirua. He decided it was their next place of settlement due to its abundance of plentiful resources and beautiful landscape and he

believed it was the most attractive place to settle south of Kawhia (Oliver). This beauty and these abundant resources have since been depleted and the rich history the Porirua Harbour once shared with the Ngäti Toa people

has gradually disappeared. Today, we have seen a decline in awareness of cultural landscapes and traditional Māori methods among the local people.

To reconnect people with the environment through awareness of cultural values and traditional methods, problems currently affecting the people and environment must first be addressed. This research will examine the local iwi of Porirua, Ngāti Toa. The focus will be on the problems currently troubling the Takapūwāhia community, which is the home of Ngāti Toa Pa (settlement), Takapūwāhia Marae. There will be exploration of ways to restore cultural values to the people of Takapūwāhia through participatory and consultative design and to enable awareness of the significance of their rich history. The research does not aim to fix environmental problems, but through designing culturally enhanced environments, to unite the community of Takapūwāhia.

\section{The Influence}

CULTURAL SHIFT

The Change Over Time

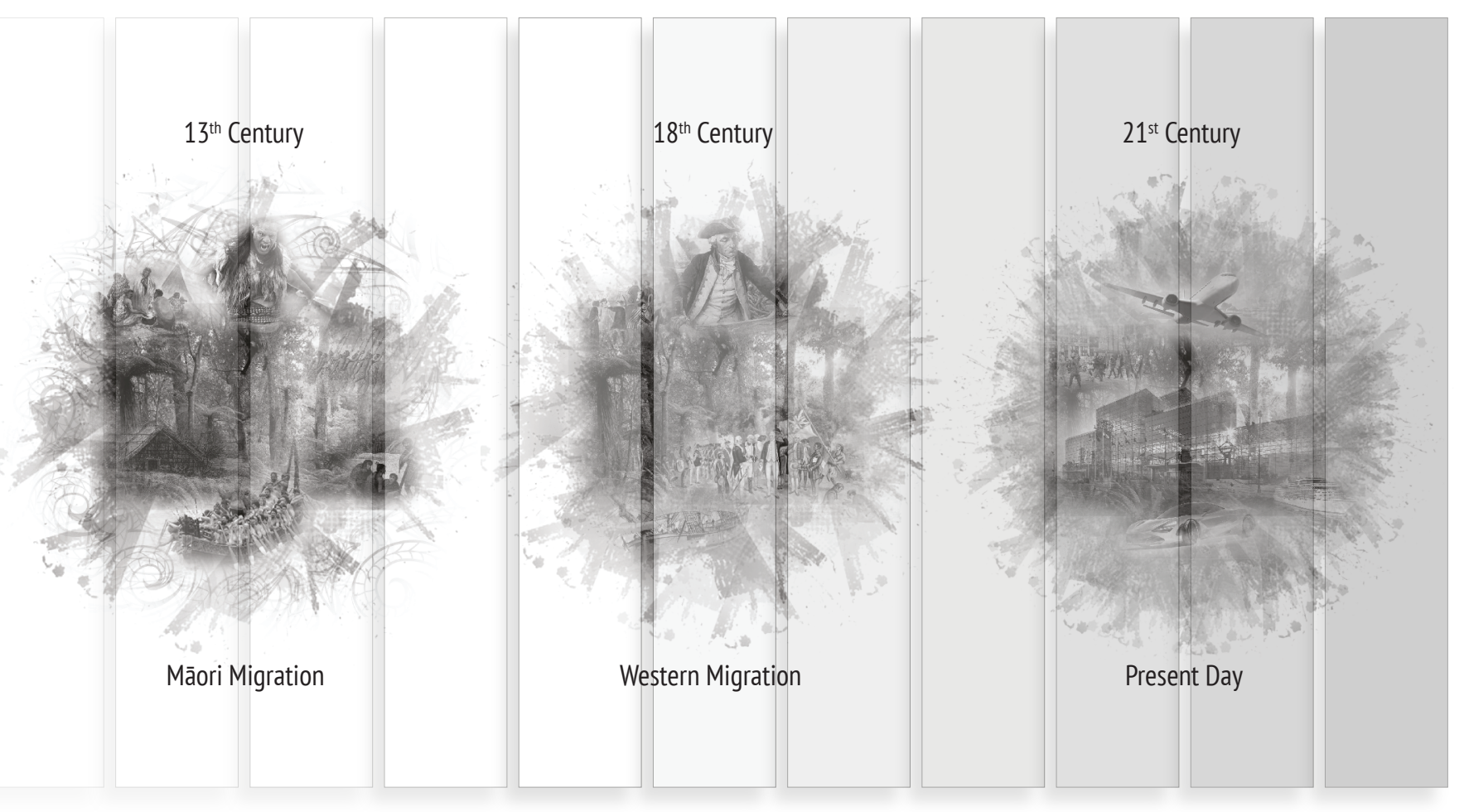

Fig.01: Cultural change over time.

The cultural shifts have impacted on society today through the migration of different cultures and different ways of understanding the environment and the people. These shifts have influenced the use of the environment and the values of the Indigenous people. 


\begin{tabular}{l|l} 
The Problem \\
\hline $\begin{array}{c}\text { The LOSS OF INDIGENOUS values } \\
\text { The Transition }\end{array}$
\end{tabular}
The Transition

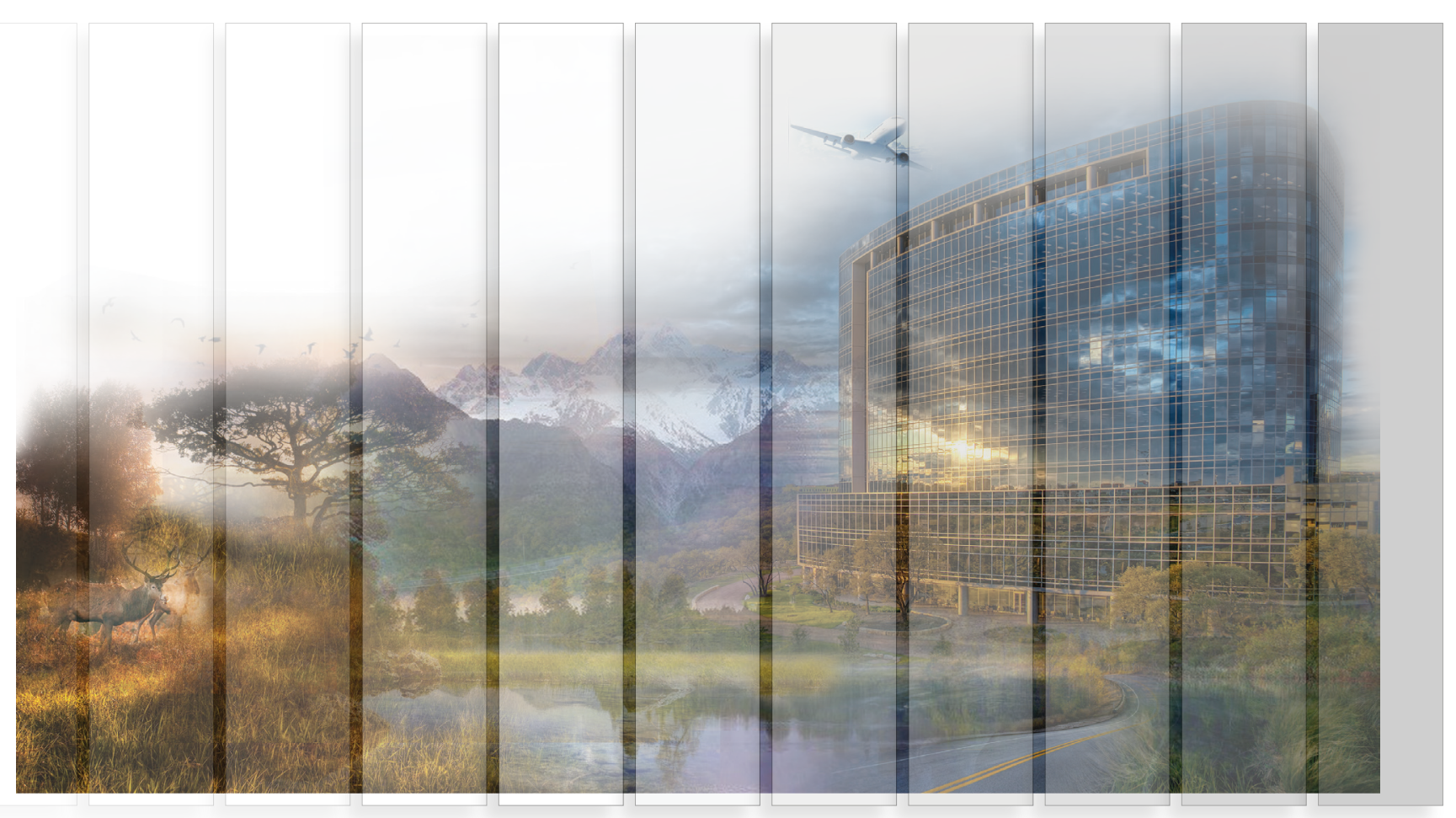

Fig. 02: The transition from natural environment to built environment

The influence of Western culture on the environment and the Indigenous people has affected traditional practices and caused a significant decline in Indigenous values being incorporated in communities. Urban development has played a major role in this problem as it has affected the environment and the Indigenous way of life.

\section{The Implications}

THE AFFECT ON COMMUNITIES The Disconnection

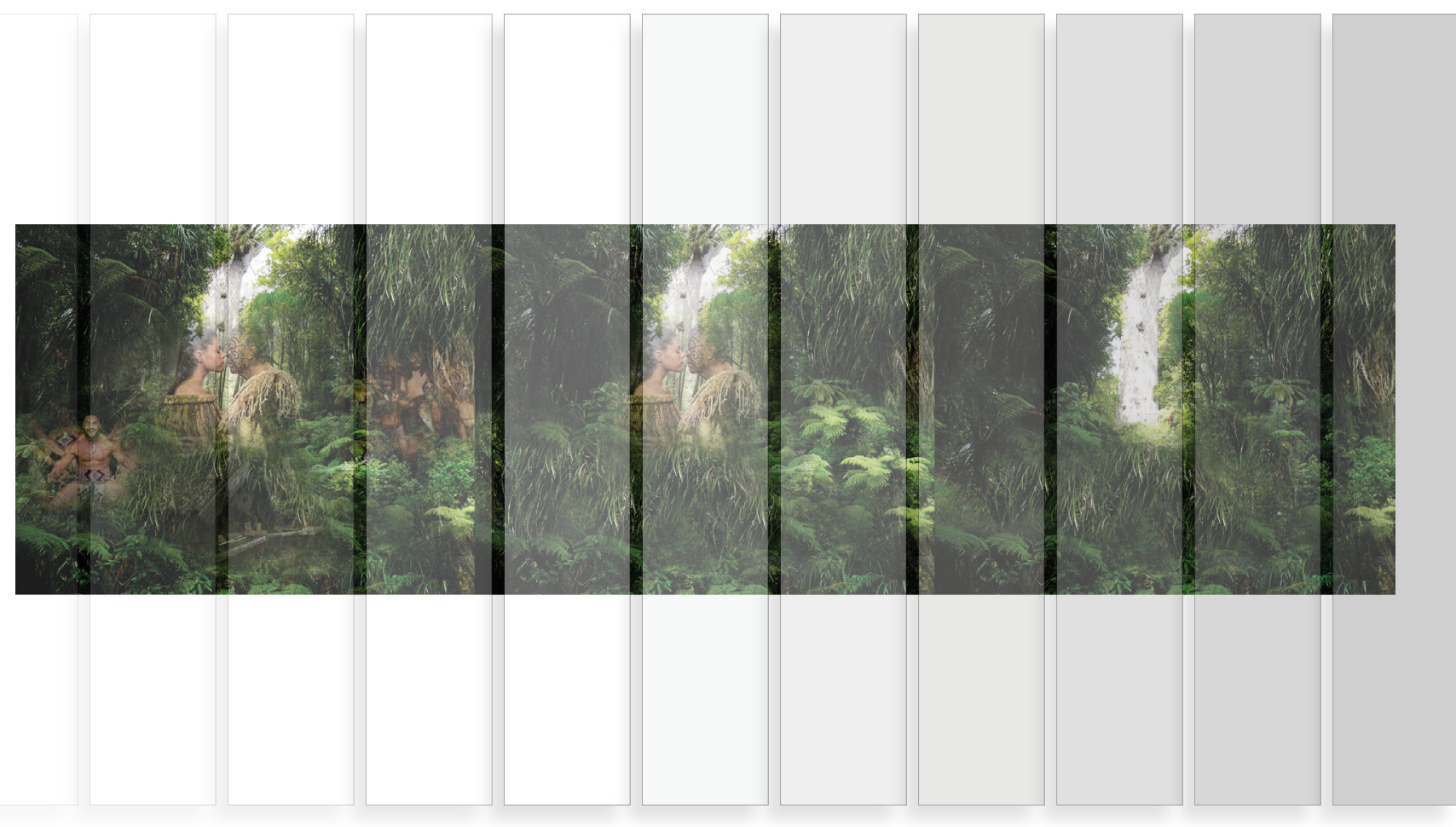

Fig. 03: The disconnection from cultural values.

The disconnection between place and people has caused a loss of values related to the environment and traditional ways of doing things. This has affected communities to the extent that there are lack of resources available and lack of knowledge regarding cultural practices that once were essential to uniting people to work together to sustain a healthy environment and foster community engagement. 


\section{THE QUESTION}

HOW CAN WE UNITE A COMMUNITY BY IMPLEMENTING INDIGENOUS

VALUES WHEN DESIGNING FOR PEOPLE?

\section{CORE MĀORI VALUES}

Mātauranga Māori-Māori Knowledge

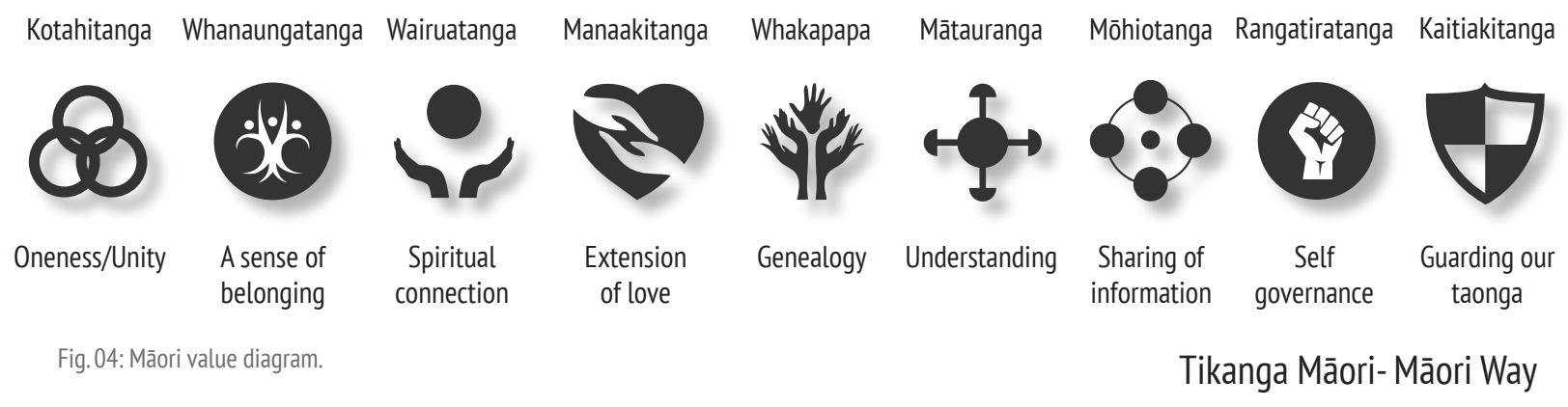




\section{Research Proposal}

RESEARCH INTENTION

The research intends to explore Indigenous values that can be incorporated into designing

for a community. This approach will attempt

to reconnect people with the environment

through Indigenous values and practices.

\section{AIMS AND OBJECTIVES}

The aim is to incorporate specific guiding tools that will be instrumental in answering the research question. These tools will contribute

to the final project as they will provide a

platform for what objectives need to be

executed in accomplishing a successful design outcome.

The guiding tools will aim to:

Reconnect

- Transfer of Māori values and ways

- Representation of land through its people

- Enable identification with the place

- Encourage awareness of traditional

knowledge

- Consideration of the Indigenous

Incorporate local experiments

- Enable bonding and bridging of the

community

- Utilise unused green spaces

- Create useful facilities for society
Create visual infrastructure

Benefit communities

Communicate through design

Educate in design

-Grow relationships with the environment

- Integrate theory with practice

Encourage learning process

- Acknowledge Māori culture

- Use a design-led research approach

-Designer to take the role of facilitator

Encourage community engagement

- Public engagement

-Commitment to the community

Help Indigenous people

- Focus on problem areas

Employ participatory design

Understand cultural environment

-Encourage community design decision

making

Find a solution to existing challenges

- Reconnect community

- Counter Mãori youth disassociation

- Increase educational outcome

Connect to Whakapapa (genealogy)

- Increase opportunities

- Incorporate Māori values

- Mitigate environmental issues

- Create connection between people, culture

and environment

\section{Methodology}

\section{RESEARCH METHOD}

The project will be guided by a design-led research approach that incorporates Kaupapa

Māori (Māori way) methodology. In a Kaupapa Māori Research paradigm, research is about "setting new directions for the priorities, policies, and practices of research for, by and with Mãori" (Smith). Understanding and representing Măori, as Mãori is an essential aspect of Kaupapa Māori Research.

The research will commence by selecting a site that has a rich cultural history, but where there is a sense of disconnection between

the cultural identity and the people of the place. A systematic literature review will

determine sources that present similar design approaches and techniques. These sources will explore processes that display the benefits

of landscape architecture and participatory design approaches when designing for

communities and seeking to portray cultural significance. These processes will also investigate different aspects of community development through the explorations of participation, education, learning and reconnection to lost Indigenous values, as well as how communities can be united and the environment enhanced.
Through the research and understanding of relevant information accumulated in the literature review, the research question will be refined. The knowledge of the research process will lead to an investigation and experimentation with a local Indigenous community. This will incorporate analysis of existing environmental and social factors that contribute to this community. The study will determine the strengths, weaknesses and design potential, which will be accompanied by various forms of design testing with the community, the environment and the cultura values of the Indigenous people.

Following extensive analysis and testing with the community, experimentations will be mplemented through design strategies and systematic outcomes discovered during the exploration of case studies. This will be taken back to the community with the intention of creating design solutions most suitable for the people and their environment. The response from the community will determine an appropriate way forward to finding a design solution for the community and with cultural values driving the project. 


\section{Introduction}

Aotearoa (New Zealand) is a country with a rich history with regards to its' Indigenous people. They shared a deep relationship with the landscape that was essential to their way of life. This dated back to the thirteenth century when the migration of Polynesian

people, who are now known as the Indigenous Māori, arrived in Aotearoa (Wilson). They found a land rich in resources with an abundance of life on land and sea and this influenced their decision to settle there. The Polynesian people brought with them tradition and values that had been passed down through generation after generation. These values and culture were incorporated into their new way of life in Aotearoa through everyday activities and practices that proved essential to their development and existence in Aotearoa.

The nineteenth-century saw the migration of European settlers which was not the first contact between Europeans and Aotearoa, as European explorers had ventured to the land as early as the seventeenth and eighteenth centuries. However, it was not until 1840 when

the Treaty of Waitangi was signed, that the Europeans began to call New Zealand home (Orange). That became the defining moment which would forever change the way of life for Indigenous Māori people in Aotearoa, who had agreed to collaborate and partner with the uropean settlers. From then, the Europeans began to implement their influence and authority on the land (Orange). It became evident with the introduction of a new built environment, and a new way of life that would result in change to the landscape. Thi change would not only impact the natura environment, but also compromise Māori beliefs. "Mãori maintain beliefs such as 'mauri' or life force and strong principles like guardianship of the land. These principles made sure that indigenous Mãori valued both the tangible, expressed through mountain, river and place of a tribe, and intangible, told and retold through myths and stories about people and place" (Whaanga-Schollum).

The influence of European culture on the Māori people was inevitable, and they began to integrate into European culture and society. Māori values such as Whanaungatanga, 'sense of belonging', Kaitiakitanga,'guardianship and protection' and Rangatiratanga,'selfgovernance' (Rangatira) among others began to vanish leading to a cultural shift that would change the outlook on life for the Indigenous Māori people (Pool, Māori Health, Colonization and Post-Colonization: Aotearoa New Zealand, from 1769).The new built environment began 


\section{Indigenous Values}

to impact on the natural environment and the abundance of resources provided by the land and waterways started to decline; concrete jungles replaced nature's ngahere 'forest', manu 'birds' and kararehe 'animals', pipes and sewage replaced natural waterways and freshwater for ika 'fish' and korare 'vegetation' to thrive. The connection between the Māori people and the natural environment would start to lose its essence of Whanaungatanga 'sense of belonging' and Kaitiakitanga 'guardianship and protection' (Rangatira). This loss would challenge Māori's reliance on the land and its resources, which were replaced by new styles of housing and infrastructure. This connection between the people and the environment would be compromised. Because "the important challenge in the modern context being the wise use of natural resources in a way which is consistent with the values passed onto us by our tupuna.... This challenge also includes the wise use of natural resources, knowledge and technology passed onto us" (Tau). This cultural shift started to have a negative impact and contribute to the decline of tribal and traditional influence on Mãori communities across Aotearoa (Robinson). Therefore, Māori communities saw the need to reconnect to conventional Māori values and Māori ways, which were essential to their development.
Disconnection between Māori people and their environment has become a critical issue to address to restore Indigenous values into communities. Core Māori values state that

land, water, and air are essential ingredients of life, to be respected, cherished, and sustained (Authority of NZ Conservation). These values diminished through the European influence on the environment and the people (Pool, Death rates and life expectancy). We face the challenge of bringing back those values int the communities not only the environment but with each othe to make a healthy and cohesive community.

This literature review explores:

- The loss of Indigenous values and how it has impacted the relationship between people, land and their communities.

The importance of community engagement and achieving a strong cohesive community.

- The incorporation of participatory design to achieve the best results in designing with and for the people of the community.

The need for restoration of the connection between people and place to achieve a reconnection to the space.
How has the loss of Indigenous values impacted communities and the relationship between the people and the landscape?

Indigenous values can define the people, the land, the culture and the identity of a place. Aotearoa is no different, as the Indigenous Mãori people who have graced the land since the thirteenth century, bring a sense of identity and culture that is unique to Aotearoa. They can attribute this uniqueness to the they share with the very land gifted to them (Ministry of Social Development). Essential to the relationship between the Māori people and the land are the Mãori values they share, such as whanaungatanga 'sense of belonging', kaitiakitanga 'guarding our taonga', kotahitanga 'unity', manaakitanga 'extension of love' and mauri 'our life force'. These values, constructed from the relationship, experience, experimentation, and traditional methods the Māori people shared with the land had become a blueprint for Māori people who passed these values down, generation after generation.

Since the first Western migration to Aotearoa, there has been dramatic shift of influence on Māori people, their values, traditional knowledge and the native landscape of Aotearoa. The impact of Western culture and the cultural shift has seen an introduction of urbanization and the exploitation of natural environments in Aotearoa. This shift has altered native ecologies and people, through the depletion of natural systems such as the landscapes and waterways. These natural systems are what the Indigenous values of Māori built their sense of identity and beliefs on (Māori Culture \& Impact of West/New

Zealand). This change has caused a disconnect between the Mãori people and the land which has led to Indigenous values being overlooked that are essential to their identity as Tangata Whenua 'people of the land', and their appreciation of Mana Whenua power of the land' and Kaitiakitanga 'guarding/protecting natural resources'. Whaanga-Schollum believes 'The key value for Māori to understand the land, is 'taonga tuku iho', to treat the land as a treasure that has been passed down from their 'whakapapa' or their ancestors. This treasure of the land gives the Māori people responsibility and obligations for guarding the territory and making sure the past, present, and future enerations continue that relationship with the land" (Whaanga-Schollum). 
According to Won Seok Jang, there are different characteristics between that of Western culture and Eastern culture, such as Māori. He considers there: "Might be that Western culture is thought to be rational and goal-oriented. It understands the world as a single ordered whole with universal principles, and where humans are superior to the animal world, living with nature. In comparison, Eastern cultures are thought to be based on aesthetics, with highly developed arts and religion. They are said to adopt an experiential approach to knowledge, with an emphasis on the unique rather than transcendental principles. With the human being at one with and in nature" (Jang).

This basis is also elaborated more through similarities in values the Māori share with other Eastern cultures, such as the Chinese. Māori convey their aspirations, ethics, and values about land through words. Chinese use naming and calligraphy in gardens and Mãori use specific words to correlate a powerful meaning. For instance, Māori would use the terminology of 'Tangata Whenua' to represent land. Tangata Whenua translates to "people of the land, which defines the land one with the people instead of referring to it as a separate entity. These words often repeated in proverbs and aphorisms, for example, 'Kerry Hulme' states "Toi te kupu, toi te mana, toi te whenua.
Language, prestige and land are the foundation of Māori culture and values" (Hulme). Another similarity to Chinese culture is that Māori would laden the naming of the place with messages, beliefs, events and stories. Unfortunately these have been compromised due to the change in land and culture. This change has not allowed these significant attributes of Mãori culture to be passed down, with the disconnection between the people and the land. The adoption of Western civilization and Western values have proven a significant influence on Mãori communities and the native environments they built the values around.

In consideration of the issues that are interfering with the connection between Māori people and Māori values, there have been multiple initiatives to address the problem. One example expressed in the research of Diane Menzies shows "several Māori tribes have put resources into developing 'iwi' tribal management plans. These plans set out their beliefs and stories, as well as particular issues and opportunities. These plans have no statutory weight, although referred to in district plans. They can provide a focus for strengthening tribal identity and a means of preserving knowledge, as well as information for those wishing to understand local relationships and values. They are not undertaken by all tribes, who may lack resources to develop such plans. This decline is because they either chose not to or have different priorities and their acceptance

limited. However, more considerable attention to such ideas by decision-makers, developers, landscape architects, and other practitioners could be a catalyst to much-improved dialogue. They are certainly a first port of call in setting out to understand another culture's values, in instances when they are prepared" (Menzies, Renata and Whaanga-Schollum).

Incorporating Mãori values back into the communities of Aotearoa is essential to bringing back cultural identity and environmental awareness for the Indigenous Māori people who grace the land. Western influence has created challenges for the Mãori people and the values they built between their people and the land. Instead of shunting aside the Western culture, the real problem is to adapt with the Western influence and embrace the culture they bring, then teach the Western people the importance of Māori values towards the people and the land. That way, each cultural influence has a place to identify with and Aotearoa as one unique culture that incorporates the Māori values suited for all eople and the environment they reside in (Harmsworth). This plan will result in the reconnection of Māori values towards the Indigenous people of Aotearoa, while teachin the Western cultures that these values are essential for their people and the land. 


\section{Community Engagement}

How important is community engagement in achieving a strong and cohesive community?

Throughout society, the key to healthy and cohesive communities is the involvement of the people of the community and the engagement they have with one another. Participation is essential to developing healthy community, a community where everyone has a voice, and through interaction with each other, they can come to collective decisions, resolve issues and find solutions to crucial problems within their community (Engagement).Engagement can thrive through the introduction of participatory design. Participatory design gives the community opportunities to voice their ideas and opinion which can be addressed and developed through interactions with and under the guidance of a skilled designer.

The challenges of getting a community to engage with each other include finding commonality among the people and understanding the people of the community. A lot of communities are like a mixed bag of lollies; they come from different cultures, different age groups, different backgrounds, and different environments. The main challenge with encouraging community engagement is understanding and finding ways to bring diverse groups in the community, together. Finding commonality will help influence interaction amongst each group and hopefully promote community engagement. According to Menzies, Renata and WhaangaSchollum "another means to increase understanding, before developing ways of bringing the two belief systems together, is to build this capacity within a profession. Practitioners may be planning and designing for an indigenous client, or designing for a community. These communities may includes a range of cultures, or there may be a need to recognize the landscapes valued by indigenous communities. These are reasons, among others, that encourage capacity building by profession" (Menzies, Renata and Whaanga-Schollum). This approach requires some familiarity with a culture and their unique customs; in meeting and building relationships; and understanding the culture's values and beliefs, places of significance, principles, and techniques of engagement.

Community engagement can be encouraged through service-learning and community design studios. These proposals have been tested and proven as an effective way of encouraging community engagement. Servicelearning is a concept that integrates a teaching and learning strategy explicitly looking at providing students with opportunities to develop community engagement skills by working with members of the community. Through this engagement, students can enhance their group, organizational and interpersonal skills. They can also gain valuable experience working with diverse members of their communities. This experience integrates meaningful community service with instruction and reflection to enrich the learning experience, teach civic responsibility, and strengthen the communities (Why Use Service Learning). Through case studies and experiments trialled with students from the University of Massachusetts and the citizen of Locust Street neighbourhood in Springfield. It concluded that "community design studios, as a pedagogical approach to teaching in the design professions, has a great deal of appeal to administrators, faculty, students and communities. It presents institutions with many opportunities that link the university to their community. Opportunities that offer new skills and for students to engage in active learning situations and promote more reflective practice in design studios. It also engenders stewardship and public service that enriches the community while advancing the individual as well as the profession" (Cameron, Green). This approach also benefits the community who get delivery of free education and subjective learning, knowledge that is beyond their expertise and community engagement to further develop their relationship with one and other.

However, community design studios can provide many challenges. "Real projects can be messy and unpredictable, drawing students into complex realms. They generally require work before and after semester setting up relationships and completin products" (Cameron, Green and Forsyth). These challenges also create liability issues due to the prospect of the service provided being flawed or prepared in a less than professional manner. Who is to blame for the lack of professional work, the students? The faculty? Which leads to an unhealthy relationship between the students, faculty and the community. Therefore preparation is crucial before engaging with any community, especially Indigenous communities. It is essential to do research and analyze the community before actually approaching them This method allows you to understand the Indigenous community who may have set values and protocols that are unique to their identity. This knowledge will then give you the right platform to know how to approach and relate to this particular community. 


\section{Participatory Design}

The key to the engagement with these communities is by creating a relationship that shows you understand them, and you are invested in the commitment you share with

them This commitment allows you to gain

their trust and the opportunity to approach

this community most professionally (The NZ Curriculum).
How can participatory design achieve the best results in designing with and for the people?

Participatory design is a design approach.

This approach attempts to actively involve all relevant participants in the design process to help ensure the result meets their needs and is operational. Participatory design studios have many positive aspects which include the increase of professional education and providing opportunities to do well. These studios have emphasis on service learning that delivers educational opportunities that may be unavailable to the people of the community. It is an approach which is focused on processes and procedures of design and is not a design style. Participants are invited to cooperate with designers, researchers and developers during an innovation process (What is Participatory Design?). Potentially, they will participate

during several stages of an innovation process. They participate during the initial exploration and problem definition both to help define the problem and to focus on ideas for solutions, and during development they help evaluate proposed solutions. Maarten Pieters and

Stefanie Jansen describe co-design as "part of a complete co-creation process, which refers to the transparent process of value creation in ongoing, productive collaboration with, and supported by all relevant parties, with end users playing a central role' and covers all stages of a development process" (Pieters and Jansen).

The process of Participatory design not only proves beneficial for those in the community, but also the designer. The ability to allow the community to identify, study and solve environmental problems are a result of a participatory and hands-on approach between the designer and the community members. For designers, skills such as group process, political organizing, and communication accumulated in addition to design skills. Although community design projects have been present in design curricula for many years, typically these community design studios have functioned as ways for landscape architecture, architecture, and planning programs to provide outreach and community service" (Cameron, Green and Forsyth).

Participatory design faces many challenges. One challenge of concern is issues of power (Bratteteig and Wagner). "Since participatory designs earliest applications, the aim has been make voices heard and provide agency through participation in the design of 


\section{Reconnection to Place}

technological artefacts, infrastructures and processes. But participation does not happen by itself, and what participation means differs from time to time, place to place, and culture to culture" (Kruger, Duarte and Weibert). Participation needs to consider present conditions and allow active construction and adaption to these current conditions. To achieve this, practitioners of participatory design must be conscious of the existing power relations between those within

the participant group. This group includes facilitators and participants as well as that of the participants and the rest of the world (Duarte, Brendel and Degbelo).
How can we restore a lost connection between people and place?

Connection between people and places can help give identity to a particular space. Identity of place is generated through familiarity and understanding. This connection is developed through various ways such as emotional and physical attachment to that space. The critical challenge is maintaining that connection between people and place.An example of connecting to a place is 'place attachment'; this is the emotional bond between a person and a place. It is influenced by the persona experiences an individual has with a place. According to Giuliani “We have all experienced some form of affective bond, either positive or negative, pleasant or unpleasant, with someplace or other - a place that can be related to our current or past experience 'childhood places', sometimes to the future 'the place we dream of living in, where we would like to go/return to', and more or less restricted in scale: the house in which we live or have lived, a particular room in the home, the area around the home, the neighbourhood, the city and the country" (Giuliani).

Reconnecting to a place is very important to identifying and understanding a familiar feeling or emotion that connected you to that particular place although that familiarity can face many challenges, challenges through various reasons would divert or hinder the relationship between a person and a place. These reasons could be through changes to the place changes that have defused all feelings and emotions that once brought connection between a person and that place, or changes in ways you interacted with the space that you are no longer able to perform. Transitions in life can cause another key aspect of disconnection. Disconnection wher a person might have moved away from a place and the connection and memories they related to that space did not move with them. These are just some aspects that influence the disconnection between a person and place and the challenges that will need to be overcome to bring back that connection (Firns and Grabasch).An excellent example of reconnecting to a place can be found in 'Cultural Landscapes.' Saxby writes "Cultural andscapes encompass the activity of human beings and nature and create in individuals a sense of belonging to a place and also recognize the interdependence of man and the environment. In many ancient cultures, both indigenous and rural, there is no separation of nature and culture - the health of the natural environment and the people are 
intimately connected. The wellbeing of these

cultures is influenced by not only the health of the environment, but also the degree in which

those cultures can be actively involved in

caring for that environment" (Saxby).

Things we can consider in achieving a

reconnection to a place is by encouraging "the

feeling we experience towards certain places

and to the communities that the places help

to define and that are themselves defined

by the places - home 'family, relations,

friends', workplace 'colleagues', church 'fellow

worshippers', neighbourhood 'neighbours', city,

country, continent - certainly has a strong

positive effect in defining our identity, in filling

our life with meaning, in enriching it with

values, goals and significance." (Giuliani) 


\section{IDENTITY, SPACE AND PLACE}

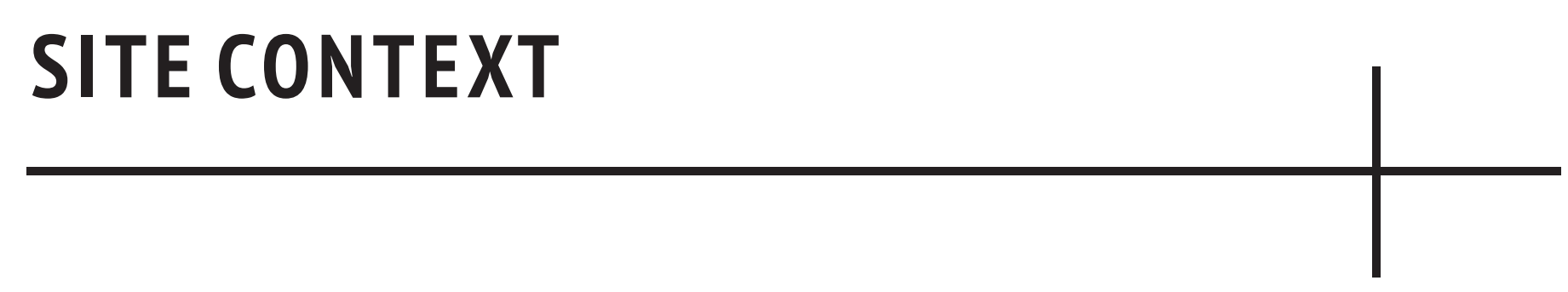

UNDERSTANDING THE CULTURAL, ENVIRONMENTAL AND COMMUNITY

FRAMEWORK

$\mid$




\section{Porirua Geography}

THE GEOGRAPHY OF PORIRUA

Porirua City, located in the lower North Island of New Zealand, is one of four cities in the Wellington Metropolitan Area alongside

Wellington City, Lower Hutt and Upper Hutt. It has a population of 56,800 people and covers an overall land area of $182.39 \mathrm{~km}^{2}$, consisting of 16 suburbs. Porirua formed around the arms of the Porirua Harbour and the coastline facing out to Cook Strait and the North-Eastern parts of the South Island. The most populated areas, such as Camborne, Karehana Bay, Mana, Onepoto, Papakowhai, Paremata, Pauatahanui, Plimmerton, Pukerua Bay, Takapūwāhia, Titahi Bay and Whitby, are situated on coastlines or have direct access to coastal parks and recreational reserves. Several suburbs, such as Aotea, Ascot Park and Ranui Heights, are without direct coastal access, but have excellent views over the harbour. The existing city centre around the north part of Elsdon was built on reclaimed land, resulting in a loss of access to the harbour (Porirua City).

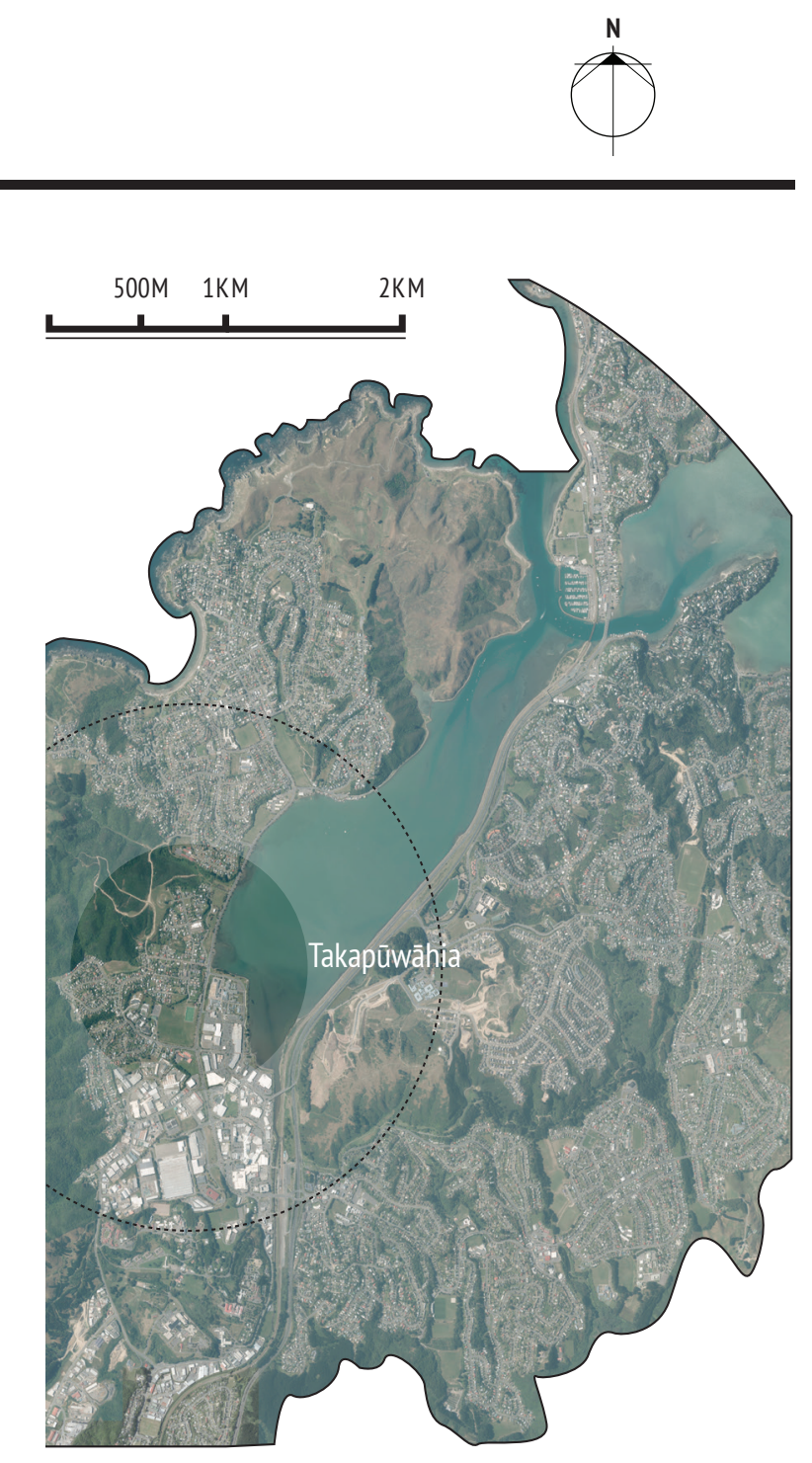

Fig. 05: Porirua site map.

\section{History}

THE DISCOVERY OF PORIRUA

Kupe, the great Polynesian navigator from Hawaiki, was the first to discover Aotearoa (New Zealand) between 900-1100AD, (NZ in History). He left his presence and influence on many corners of the land including on Porirua. Kupe was responsible for naming many great sites in Porirua, including Te Awarua-o-Porirua Harbour, Mana Island and Komanga Point

among others. He also left his mark on Poriru through the anchor stone of his canoe called Maungaroa, which rested in Ngăti Toa Domain for many decades before being taken to the National Museum (Te Papa) for safe keeping (Porirua City Heritage).

It wasn't until 1450AD that Māori settled in Porirua, which was previously known as Pari-rua 'the tide sweeping up both reaches' (Maclean).Archaeologists believe the first Māori tribes to inhabit 'Pari-rua' were Ngāti Tara and then Ngāti Ira. The tribe of Ngăti Toa settled in Porirua in the 1820s and continues to be mana whenua (guardians of the land), (Greater Wellington Council).
The Ngāti Toa iwi:

also known as Ngäti Toarangatira', trace their origins back to the Tainui canoe, captained by Hoturoa. One of Hoturoa's descendants was the chief, Tüpāhau. On a memorable occasion Tüpāhau spared the life of an enemy he had defeated in battle. After that occasion, his people became known as Toarangatira, which means the tribe of chivalrous and chiefly warriors.' Tüpāhau's grandson, a great warrior, was also named Toarangatira (Pomare).

Kupe in battle with Te Wheke

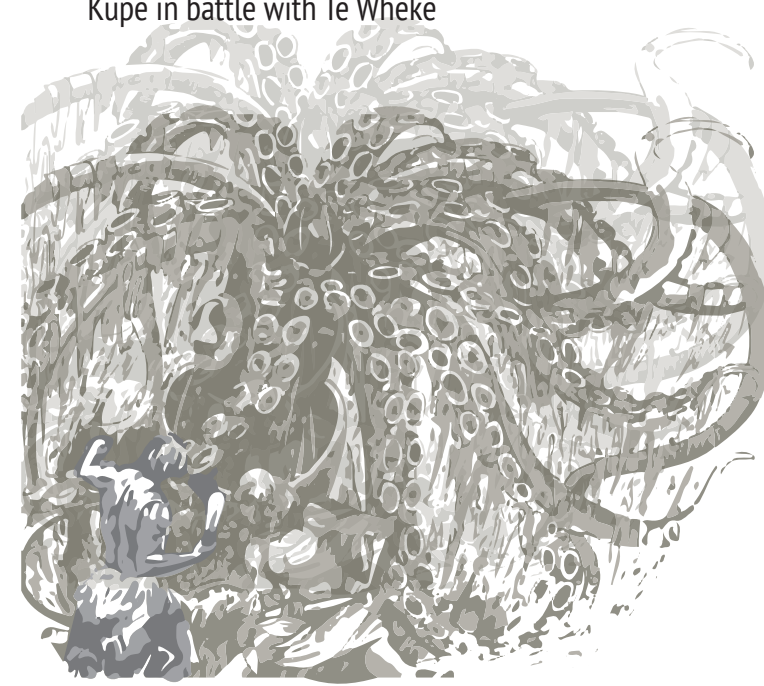

Fig. 06: Kupe and Te Wheke. 


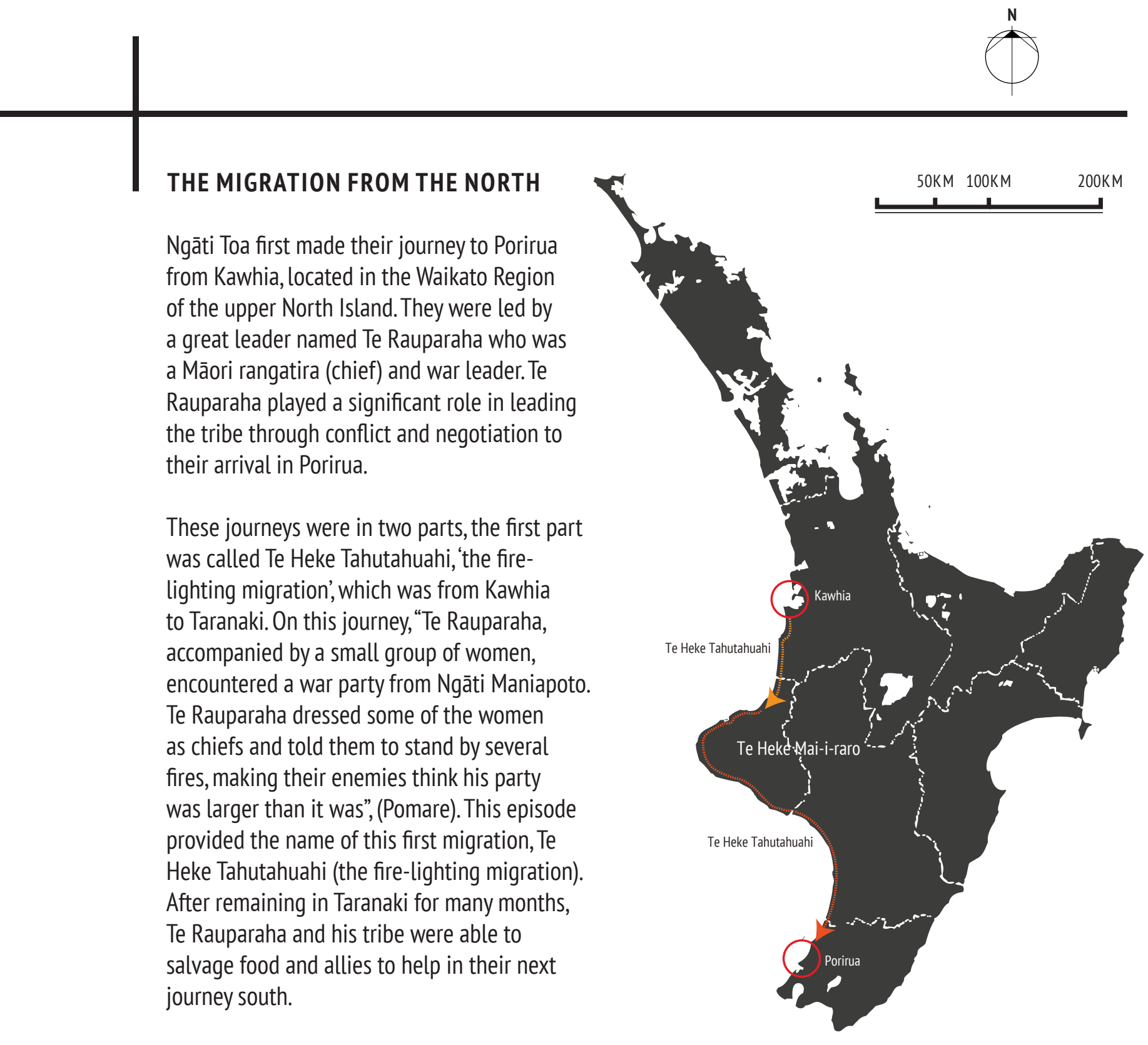

Fig. 07: Ngāti Toa journey map.
This next journey is known as Te Heke Tataramoa, 'the bramble bush migration' "This journey was arduous. The migrants had to contend with many obstacles, including hostile tribes in southern Taranaki, Whanganui, Manawatū and Horowhenua" (Pomare). The difficulties they encountered on this journey are indicated by the name Te Heke Tataramoa, 'the bramble bush migration', which signifies the forcing of one's way through the New Zealand scrub.

The whole journey was called Te Heke Mai-i-raro (the migration from the north). Many generations later, descendants of the migrating peoples named their meeting house Te Heke Mai Raro, in acknowledgement of the significance of the event in their history. The house was opened in 1997 and stood at Hongoeka marae, Plimmerton, not far from the site of Te Rauparaha's principal residence at Taupo pa (Pomare).

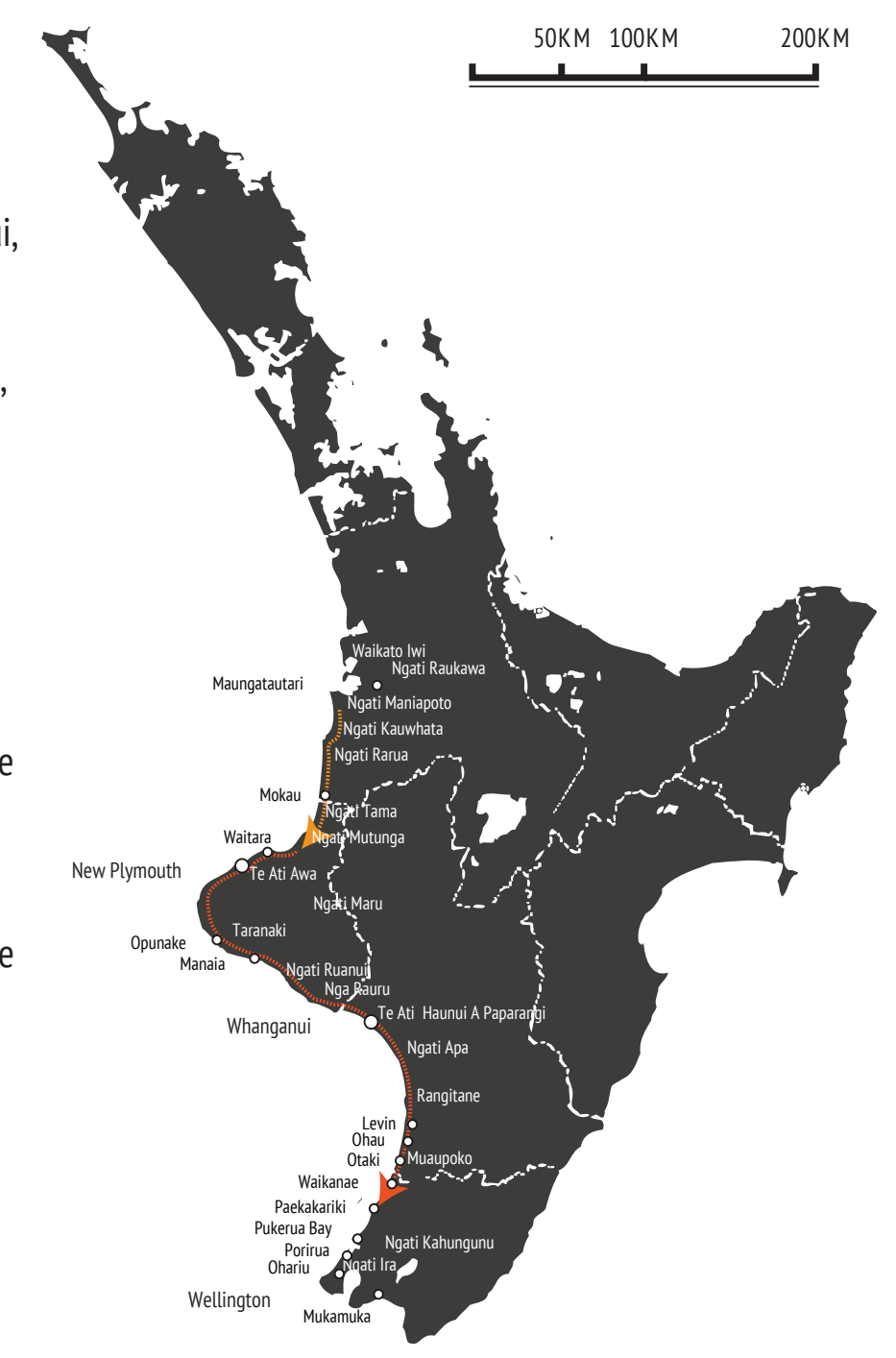

Fig. 08: Ngäti Toa iwi encounters. 
TE AWARUA-0-PORIRUA HARBOUR

Harbour Rich in Resources

After their migration from the north, Porirua became an attractive choice for Te Rauparaha and his tribe to settle, due to its abundance of plentiful resources and beautiful landscape. In fact, he considered it the most attractive place to settle south of Kawhia. The harbour was vibrant with kaimoana (seafood) and Māori people fished and gathered shellfish such as kina, paua, and kuku along the coast. Kai awa (freshwater food) such as tuna (eel) was also found in the freshwater streams feeding into the harbour and these were also a great source of food. The land was abundant with fresh vegetation such as puha and kumara, which were essential sources of food for the

Māori people. Dense patches of harakeke 'flax' covered the ground on and around the edge of the harbour, which would become a valuable resource for making baskets and weavings that were essential for food gathering and shelter. (Oliver) Porirua was a thriving food basket and became the perfect place for Te Rauparaha to settle his people.

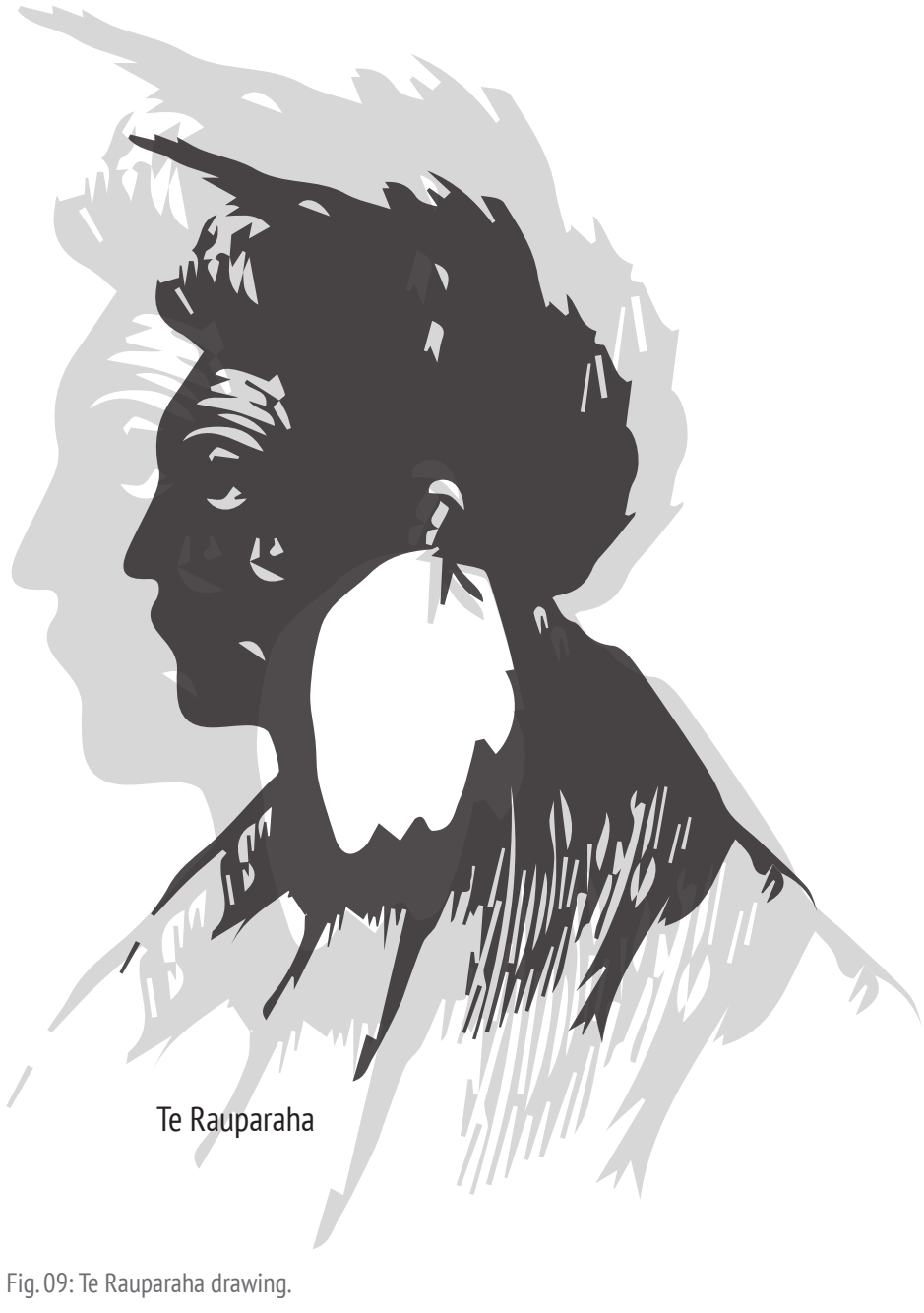

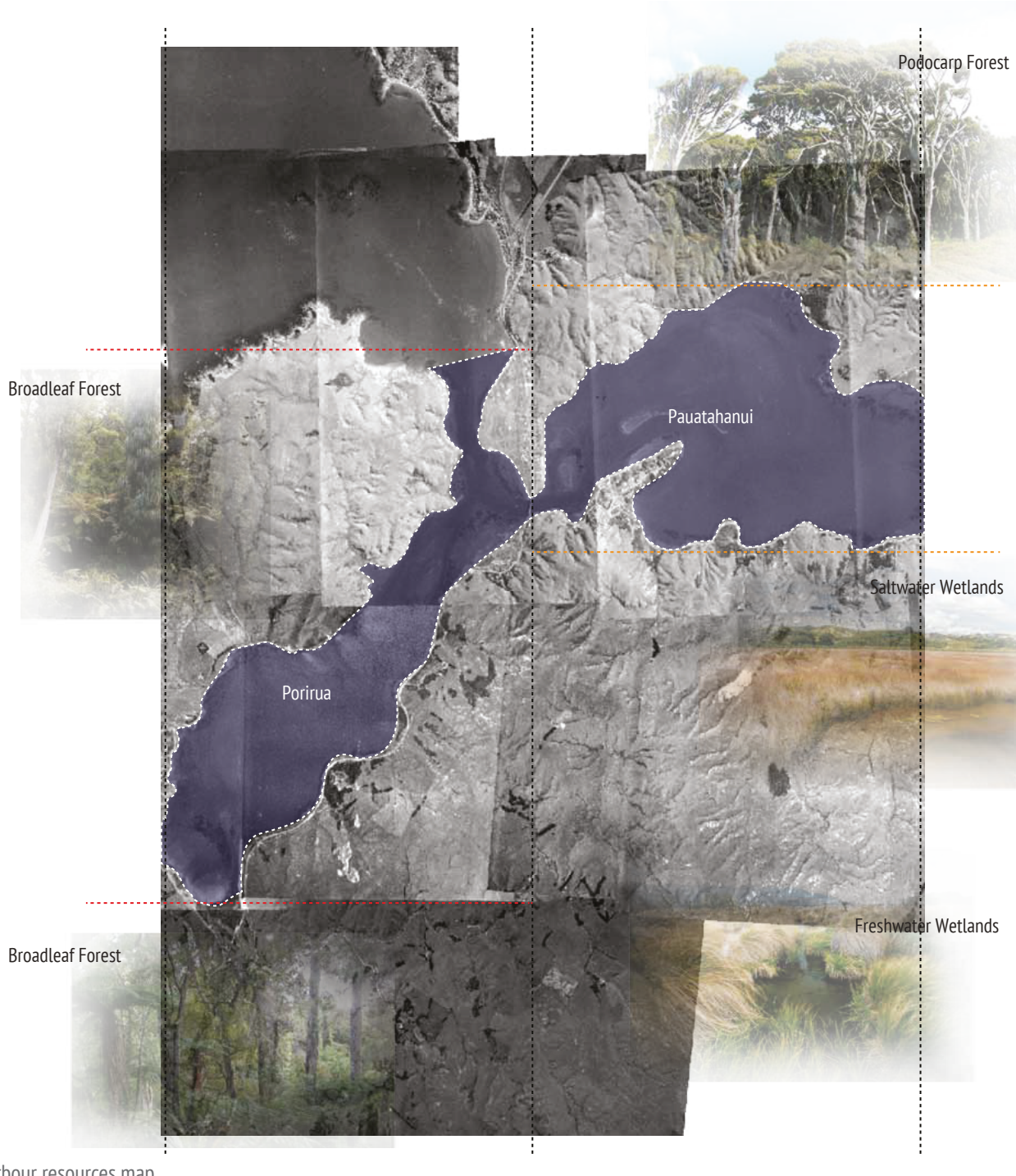

Te Rauparaha and his tribe settled in Porirua due to the abundance of plentiful resources and beautiful landscape. In fact, he considered it the most attractive place to settle south of Kawhia. 
TE AWARUA-0-PORIRUA HARBOUR

Harbour Influential in Traditional Practices

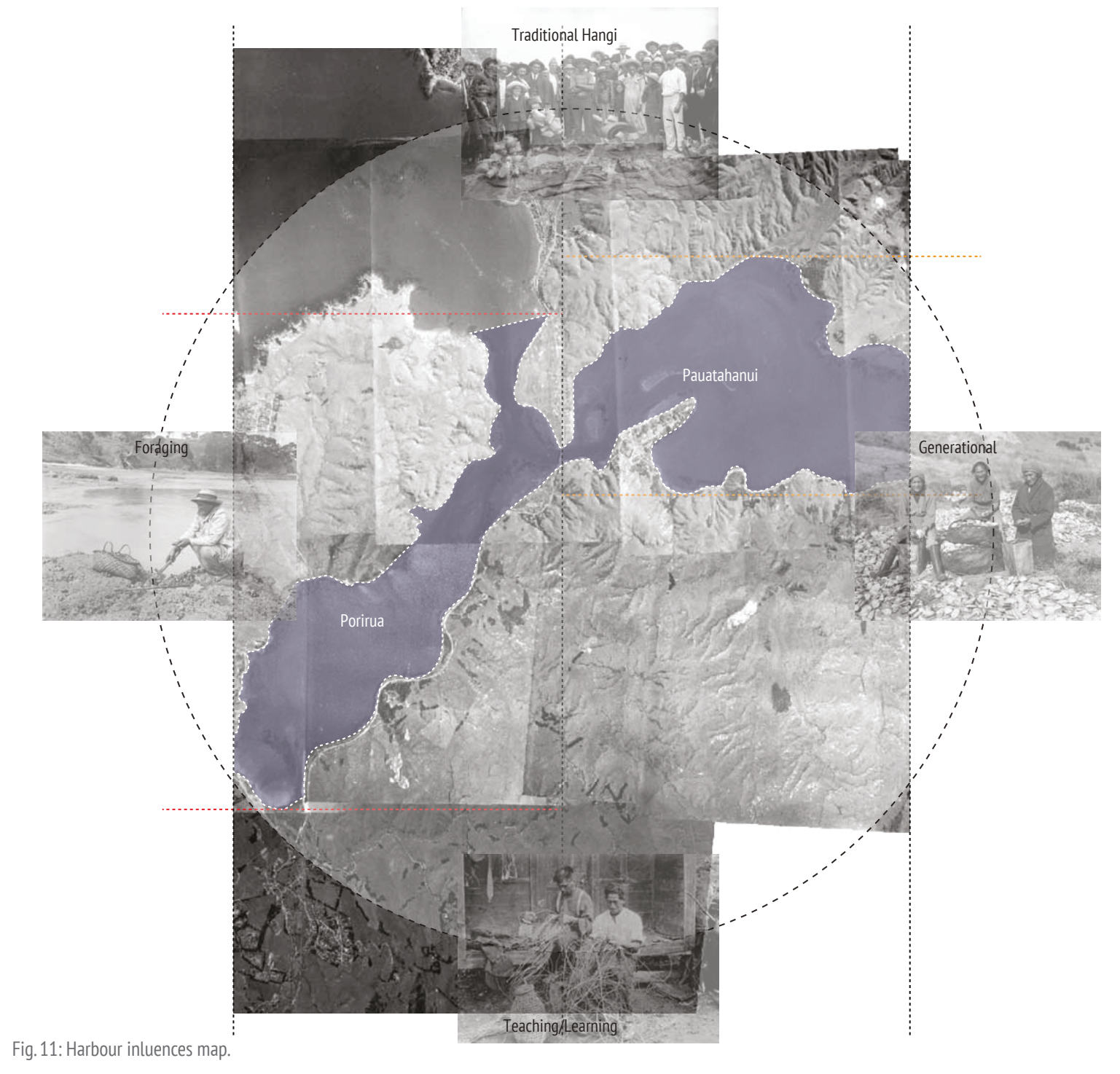

The harbour was influential in traditional practices such as:

Teaching/Learning: Elders teaching the young how to be sustainable and efficient with the resources available. Foraging: Food gathering because it was abundant and essential to life.

Generational: Traditional practices were passed down generation after generation.

Traditional Hangi: Traditional ways of cooking for big gatherings and visitors.

\section{EUROPEAN MIGRATION}

Captain Cook was the first European to discover Porirua and he went on to map the Porirua Harbour during his journey around New Zealand in 1769. It wasn't until the early 1800 s that the area became populated with European settlers, who initially sought to trade land and resources with the local Ngāti Toa iwi. The Europeans also showed a keen interest in Porirua, as they saw all the potential in the harbour and the abundant resources provided by the land. They began to use Porirua as a primary trading hub which led to conflict between the Ngāti Toa iwi and the European settlers. The Europeans began to assert their dominance on the land and also on the people. After 1840 the government undermined the political and economic power of Ngāti Toa, asserting their right to the lands, harbours and coastline of the Cook Strait region Ngāti Toa made every attempt to protect their property but by 1846 tension between Ngāti Toa and European settlers culminated in several battles. The fighting was inconclusive, but Ngāti Toa's principal chiefs were removed, with Te Rauparaha arrested and Te Rangihaeata exiled and forced to retreat to the Manawatū. The Crown then forced the sale of tribal land situated on the lower North Island and upper South Island, either side of the Cook Strait (Maclean, Wellington Places - Porirua).

After the Second World War the government was desperate for new housing. Porirua had plenty of cheap land, was already linked to Wellington by railway, and a new motorway to the area was about to be built. These factors made Porirua ideal for the government's plans and the reshaping of the landscape with

housing and infrastructure began in 1960. The village of Porirua dating back to the 1860 s was no more, and soon Porirua was on the verge of becoming a city. The Kenepuru Stream was straightened, and more than 770,000 cubic metres of rock and soil were dumped at the head of the Porirua Harbour. By 1966, the new city centre was complete and east of the motorway the suburbs of Cannons Creek and Porirua East grew out of rolling farmland with more than 2,700 state houses built (Maclean, Wellington Places - Porirua).

The new additions saw a drastic change to Porirua and to the Porirua Harbour and there was a negative effect on the precious resources they provided to the Māori people. The environment saw many changes as buildings, roads and train lines were inserted into the landscape and much of the natural ecosystems that the harbour and the land provided were left devastated. This saw the decline in kaimoana, kai awa and fresh vegetation, with for example, infill and reclamation of the harbour causing the natural breeding beds of kaimoana destroyed, freshwater streams degraded, and a dramatic decline in native flora and fauna. 
TE AWARUA-0-PORIRUA HARBOUR Harbour Decline in Resources

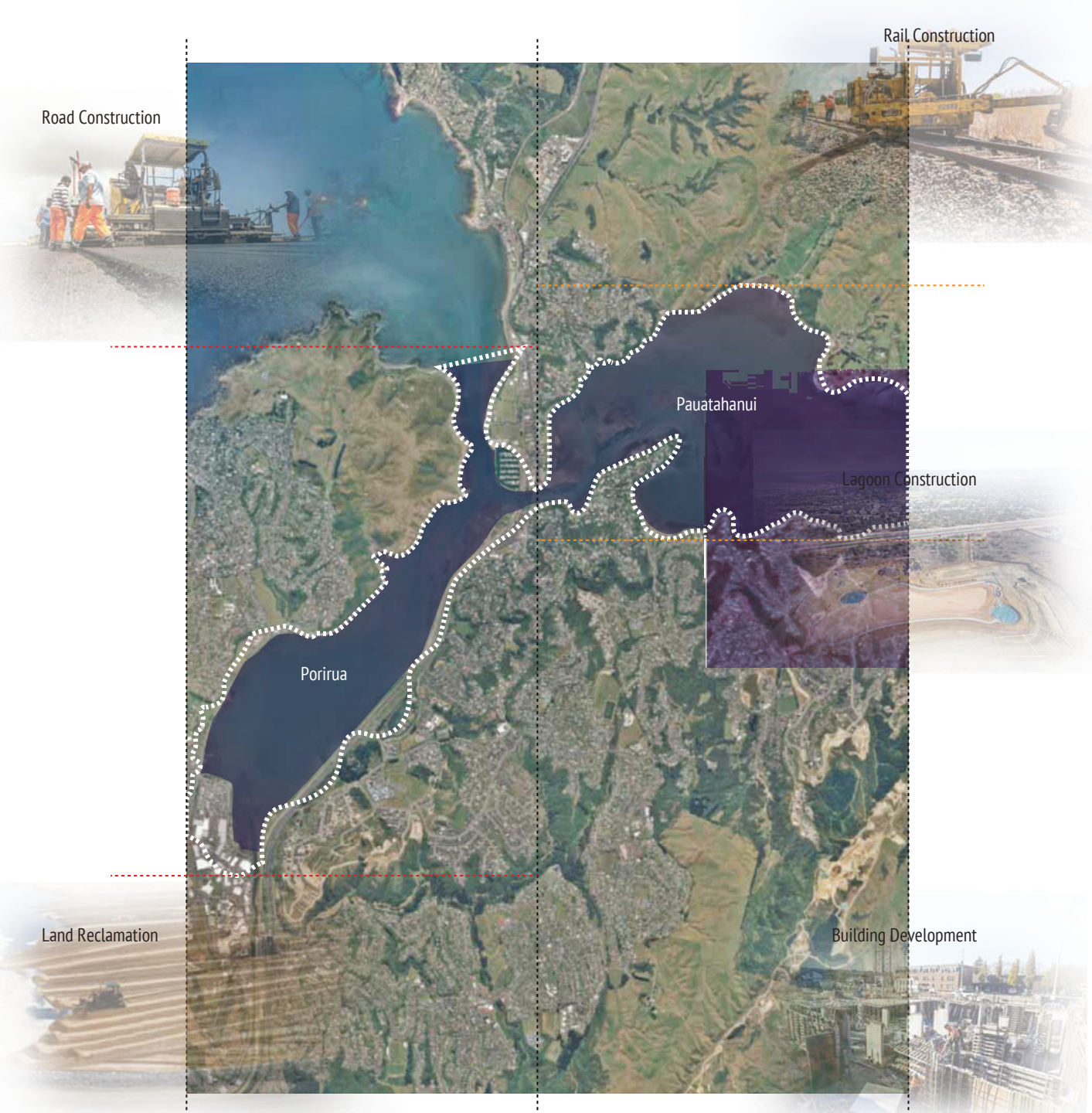

Fig. 12: Decline in resources màp.

The environment saw many changes as buildings, roads and train lines were inserted into the landscape and much of the natural eco-systems that the harbour and the land provided were left devastated.
TE AWARUA-0-PORIRUA HARBOUR

Harbour Decline in Traditional Practices

2KM

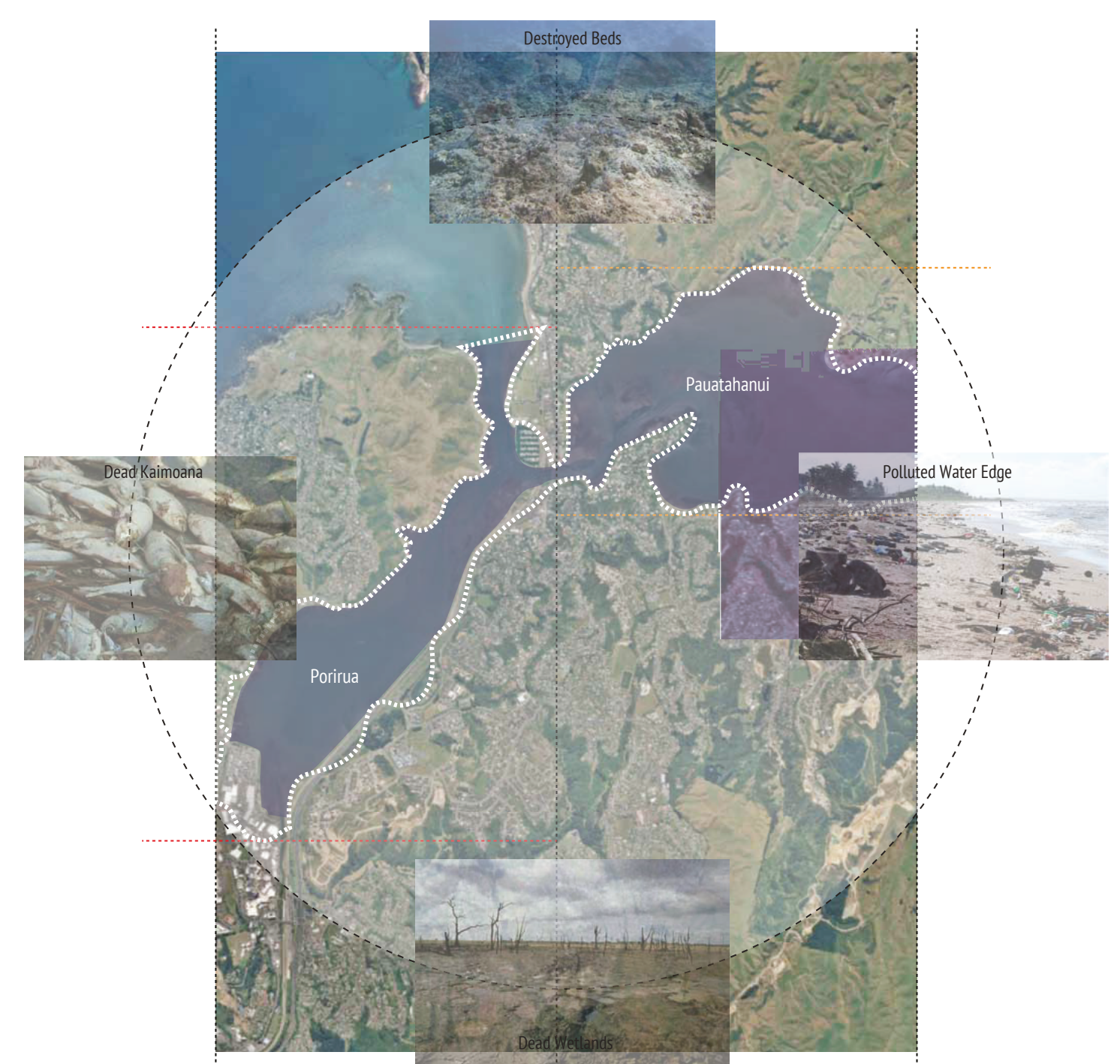

Fig. 13: Decline in traditions map.

The new additions saw a drastic change to Porirua and to the Porirua Harbour and there was a negative effect on the precious resources they provided to the Māori people and decline in traditional practices. 


\section{History of Takapūwāhia}

\section{THE BEGINNINGS OF TAKAPŪWĀHIA}

The Māori village of Takapūwāhia is located at the southern arm of Porirua Harbour on

the south-west shore. The name Takapūwāhia came from an ancient settlement in Kawhia, the ancestral home of Ngāti Toa. During the 1850s, a population of 250 Māori travelled from Taupo,(Plimmerton), to Takapūwāhia

and in 1889 Takapūwāhia became the primary settlement for the Ngāti Toa iwi. (Maclean,

Wellington Places - Porirua) Hongoeka, Taupo is believed to be one of the first places in Poriru where the Ngāti Toa people first settled in the early 1820 s. Hongoeka is home to a sub marae to Takapūwāhia Marae, known as Hongoek marae, which accommodates Ngāti Toa iwi members of Hongoeka and Takapūwāhia Ngāti Toa also had various settlements within the coastal margins and around the Porirua Harbour catchn
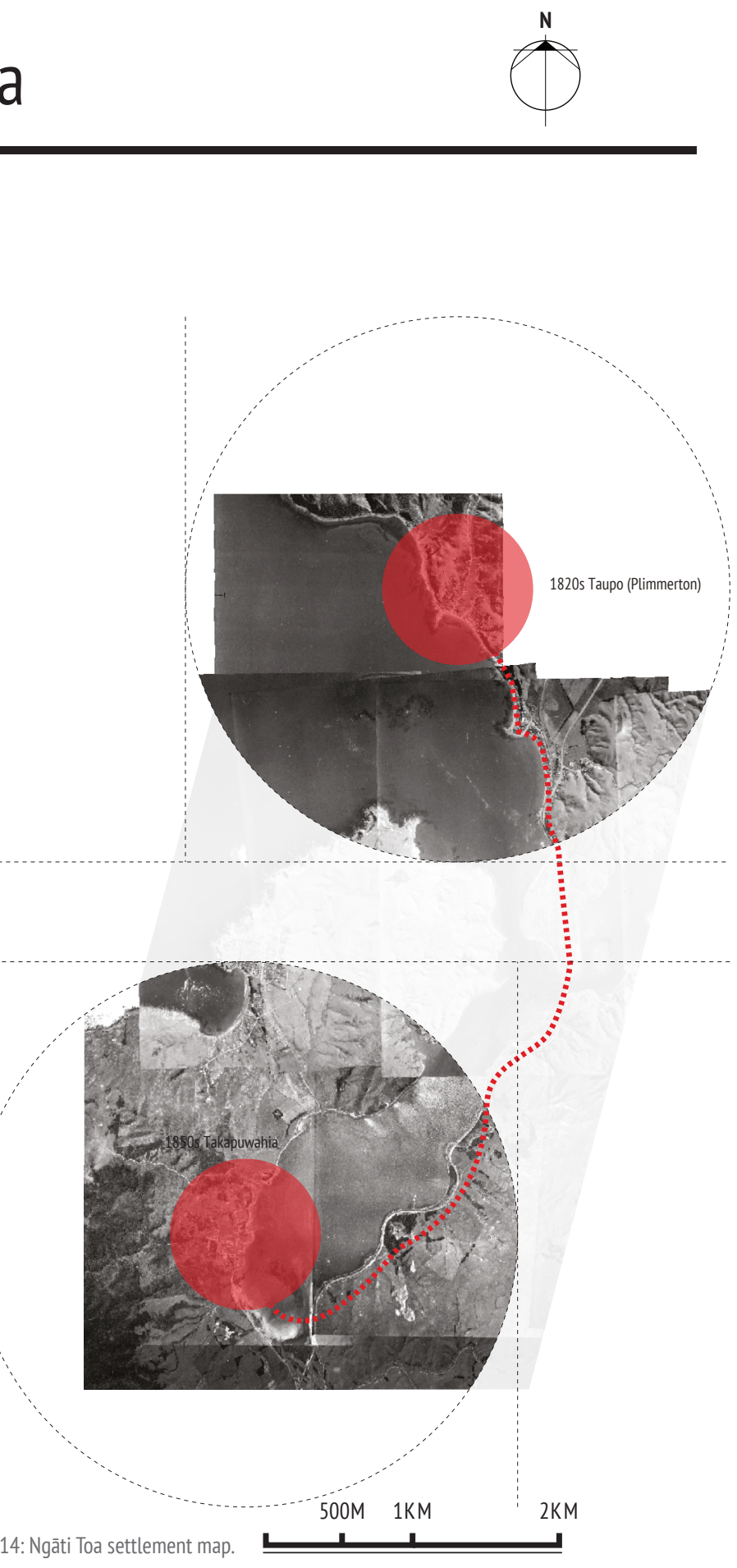

Takapūwāhia is situated mainly on flat land close to the harbour edge between this edge and the lower slopes of the Western Hills, which create a barrier between the harbour,

the settlement and the Tasman Sea. European settlers were also attracted to the area.

The increase in Europeans throughout the Porirua area encouraged the development of Takapūwāhia township and from the 1850s, the settlement that had become the primary kainga 'home' of Ngāti Toa, was fast becoming a substantial village that comprised over 50 buildings and intensive areas of cultivation with potatoes, maize, wheat and kumara (Toa Rūnanga Inc).

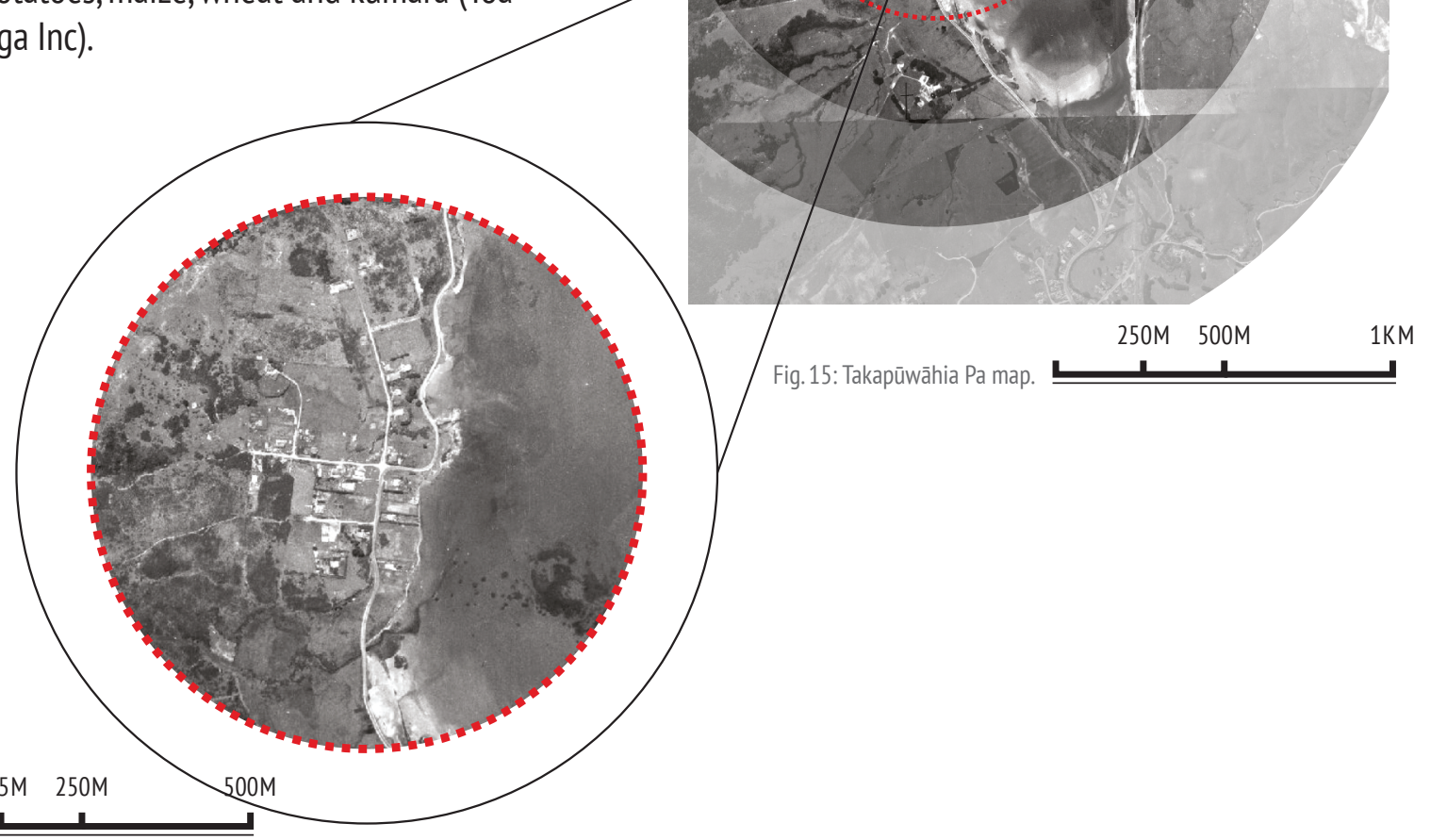


During the twentieth century the Crown began to assert heavy pressure on the Ngăti Toa iwi. This pressure created many challenges as the Crown wanted to take control of the iwi land for housing and distributing utilities such as roads, water pipes and sewage infrastructure. The development of state housing in Takapūwāhia began to take affect under the Crown during the 1940s. The Crown identified areas south-west of Takapūwāhia as suitable areas for housing development and new subdivisions. This involved some deceit, as Ngāti Toa landowners understood that these developments were for Māori housing and reserved for Ngāti Toa people. That was not the case with the Crown intending these developments for the general population (Toa Rūnanga Inc).

The Crown is understood to have accumulated land totalling 155 acres in the Takapūwāhia area. This led to Ngāti Toa whanau pursuing the return of property used for state housing by the Crown in Takapūwāhia. However, there are some positive aspects to the current situation:

Notwithstanding the many challenges of the past, the history of Ngati Ioa at Takapüwähia over adversity Nażti Toa have maintained a

continuous presence at Takapüwähia and Te

Awarua o Porirua Harbour despite numerous and

prolonged colonial policies over the 20 th century

focussed on disestablishing traditional Mãori

social and economic structures (Inc).
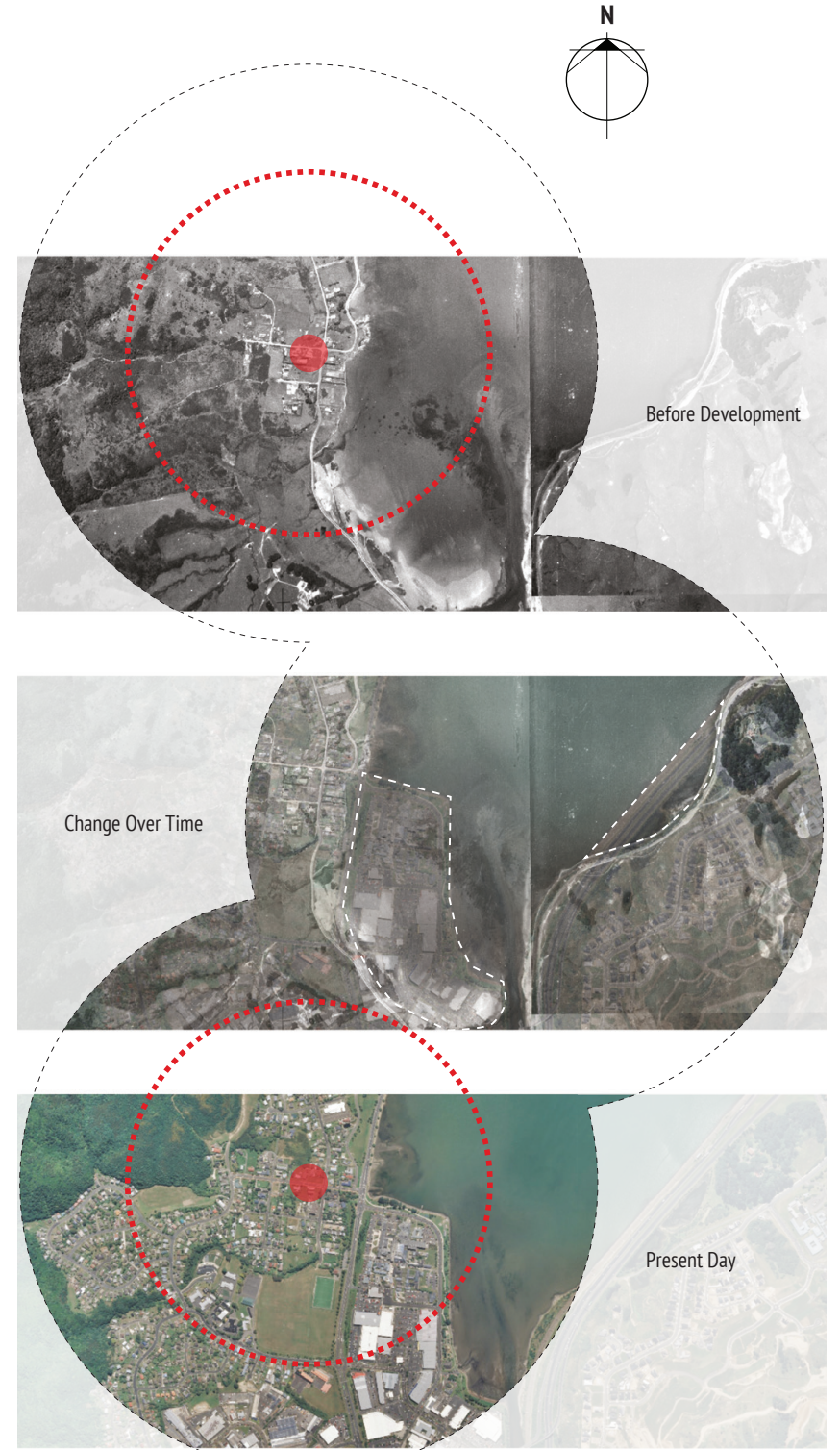

ig. 16: Takapüwähia development map. $1 \mathrm{KM}$ 1KM

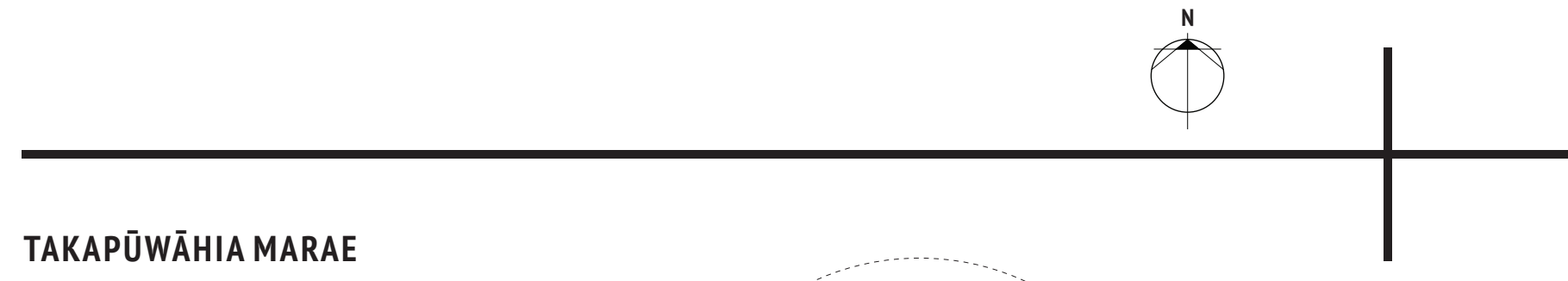

Takapūwāhia Marae is located on the corner of Te Hiko and Ngäti Toa Streets and is the centra marae for the Ngāti Toa iwi. The original

ancestral whare (house), Toa Rangatira, named

for the eponymous ancestor of the iwi, was first constructed in 1901. It wasn't until 1982 that the original whare was eventually replaced with a new carved house of the same name 'Toa Rangatira'. Takapūwāhia Marae consists of two main buildings, the wharenui (meeting house) known as Toa Rangātira and the wharekai (dining room) known as Parehounuku. Takapūwāhia Marae connects ancestrally to the waka Tainui (great ocean canoe that migrated Polynesians to New Zealand), Whitireia te maunga (the mountain) and te awa Porirua (the river or stream). In addition to the broader geographic area, the name Takapūwāhia also refers formally to the traditional marae complex. Takapūwāhia Marae is the central hub for iwi development and activity. The Rūnanga (authority) and Kaumātua council undertake meetings and conferences to address issues of importance to the iwi. The administrative offices of Te Rūnanga o Toa Rangatira Inc are situated on and around the marae complex.
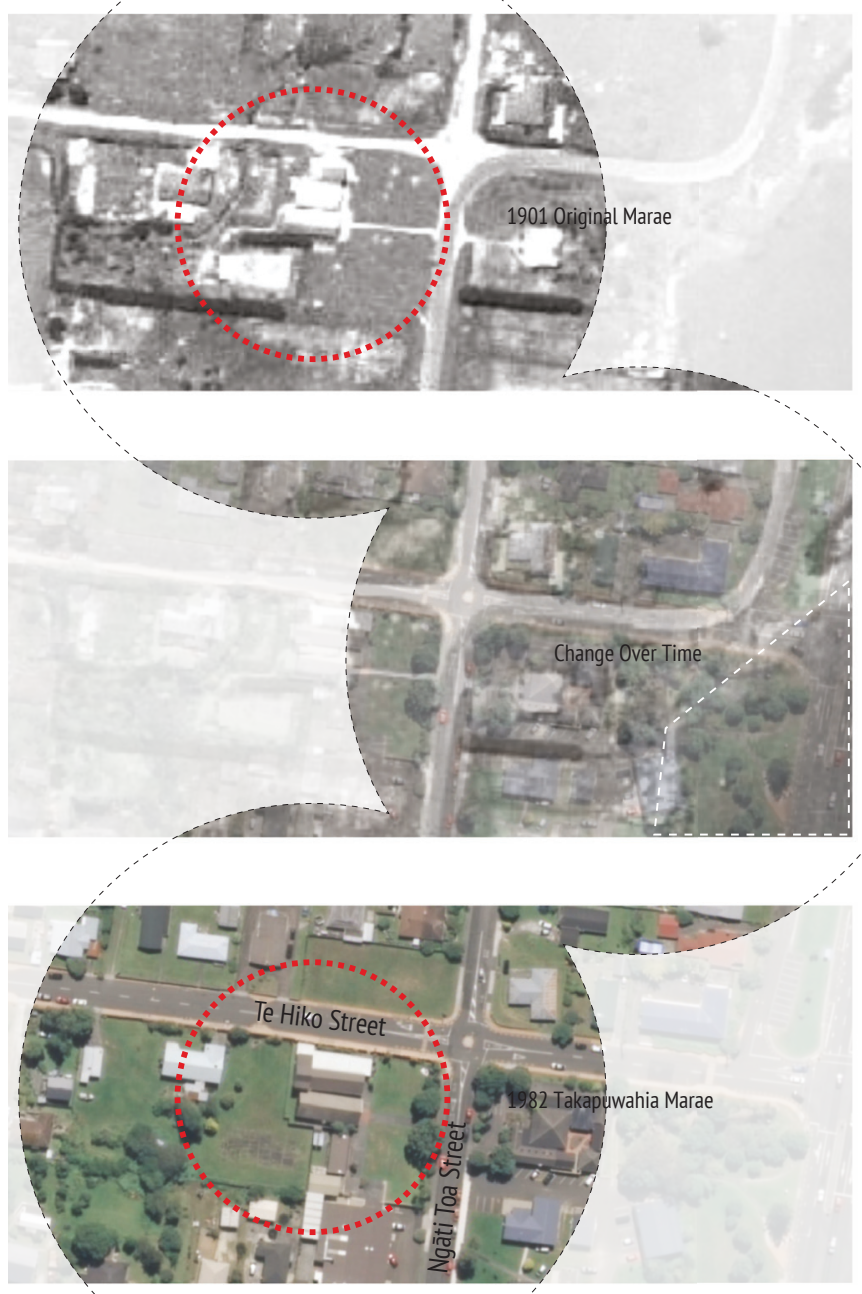

Fig. 17: Takapūwähia Marae map $25 \mathrm{M} \quad 50 \mathrm{M}$ $100 \mathrm{M}$ 
As the cultural and community hub of Takapūwāhia and the Ngāti Toa people, Takapūwāhia Marae regularly hosts public events, not only for the local community but

for the wider community as well with hundreds of community, school, professional, and

international organisations visiting every year. These events cater to people from all walks of life, ranging from school children to celebrity and sports personalities who are always

welcomed. Traditional Māori practices such as providing for guests and ensuring their comfort is of great importance amongst Māori people. These are traditions that Ngāti Toa hold in high regard and value as a fundamental practice

that represents the aroha (love) they share as people. The community at Takapūwāhia are proud to uphold the customary values of ahi kā (keeping the fire burning), manaaki tangata (cherish the place) and aroha by ensuring

that the marae continues to function in the traditional manner, and to extend the very best hospitality to their guests (Toa Rūnanga Inc). The commitment to hospitality on the marae is reliant on volunteers from the iwi. There is a tradition of whanau (family) and individuals giving back to the marae as the marae has given so much to them.
Regardless of where Ngāti Toa members reside all around the world, Takapūwāhia Marae will always be the tūrangawaewae (place of connection) for all Ngāti Toa and the place that nurtures and transmits the traditional customs and practices of Ngāti Toa. These traditions can still be found in the form of tangis (funeral) and other ceremonies that incorporate tikang (customs) and kawa (protocol). Tikanga and kawa are portrayed through significant

cultural practices such as pōwhiri (welcoming ceremony), haka (war dance) and waiata (song).

\section{SITE ANALYSIS}

ANALYSING THE EXISTING CONDITIONS IN TAKAPUWAHIA-ELSDON 


\section{Takapūwāhia Context}

DEMOGRAPHY

In the 2013 census, the population of the Takapūwāhia-Elsdon area was recorded as 2,211 people, a decrease of 57 people since the 2006 census. Takapūwāhia-Elsdon is home to $4.3 \%$ of Porirua City's overall population. Although a majority of the residents in Takapūwāhia-Elsdon identify as more than one ethnicity, the most common ethnic group is European at $49.9 \%$, followed by Māori at $49.1 \%$. The majority of Māori will classify as European as well. Takapūwāhia-Elsdon is a culturally diverse community which is also home to $29.7 \%$ Pacific Islanders and $8.3 \%$

Asian among others. There are 747 occupied dwellings and 45 unoccupied dwellings in the Takapūwāhia-Elsdon area, with the averag household of 3.2 people. The people of Takapūwāhia-Elsdon identify as a reasonably young community with the median age of 312 years, as oppose to a 35.2-year-old median age for the whole of Porirua (NZ Statistics).

\section{TOPOGRAPHY}

Takapūwāhia consists of basins, low to larg hills and steep slopes that lie between the water and the rural hill country. Some parts of the Takapūwāhia settlement occupy the steep coastal slopes and have expansive views of the harbour and sky. However, most of the residential area is on the flatter parts of the lower slopes of Colonial Knob/Rangituhi hills and in the basins. Along with the spine of hills that run north to south to the west of the suburb, Porirua Harbour is the most distinctive feature of the Takapūwāhia landscape. The suburban area is close to the coastal waters of the harbour and in addition to defining the extent of Takapūwähia, the water catchment area provides an ample open space that gives a valuable green backdrop to the suburb. The undeveloped vegetated slopes that contain

Takapūwāhia to the west are a prominent

element of the character of this suburb (Boffa Miskell Ltd).
The street pattern in Takapūwāhia relates both to topography and the period of origin development through grid divisions. The relatively flat and older areas of Takapūwāhia which have a rectilinear grid-like street pattern. Urban development has seen the growth in population and infrastructure and has come with implications for the environment and the natural systems. These negative impacts include the furthe degradation of remaining habitats, with clearance of vegetation, stormwater runoff, soil erosion and sedimentation all becoming evident in the natural environment in and round Takapūwāhia. 


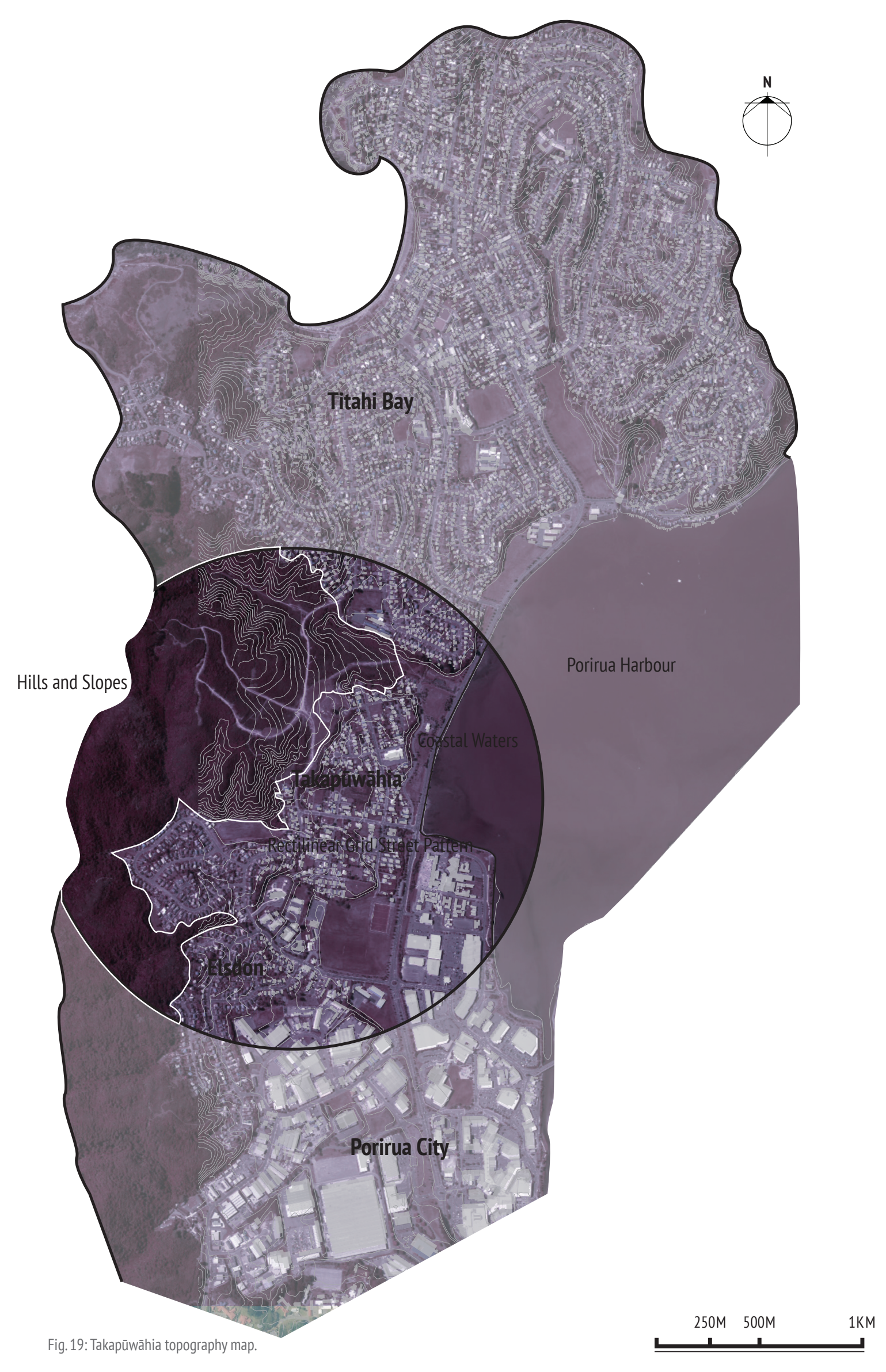

\section{VEGETATION}

Vegetation is a notable feature of Takapūwāhia,

especially in the hill backdrop and

surroundings. There is a mix of exotic plants

and native plants, although local native species

are the predominant types of vegetation

in Takapūwāhia. Relatively large areas of

young regenerating forest occur on steep

undeveloped slopes and in the steep gullies

of the Rangituhi/Colonial Knob hills which

enclose the Takapūwāhia area. The majority

of the larger spaces of native vegetation lie

within the public domain such as reserves,

and parks. Although these can still be found

in patches along the surrounding hillside of

Takapūwāhia there are large areas of mostly

pine forest.

Significant vegetation in Takapūwāhia includes

the mature pohutukawa located alongside

Titahi Bay Road, which run along the borde

of the harbour and Takapūwāhia. Takapūwāhia

is also notable for several large mature

trees, scattered in various places around the

harbours edge and hillside, many of which

are exotic species such as pine trees. Some

of these trees are significant to the area, for

example, at the urupa there is a conifer which

is a landmark for the urupa.
Vegetation has the potential to play a greater role in the natural systems related to the land and water of Takapūwāhia. The lack of significant amounts of street vegetation and wetland plants has heavily compromised the Takapūwāhia and harbour area. The lack of vegetation has made the area prone to surface flooding and overflow of water catchments which have negatively impacted the natural environment and the water quality of the streams and harbour. 


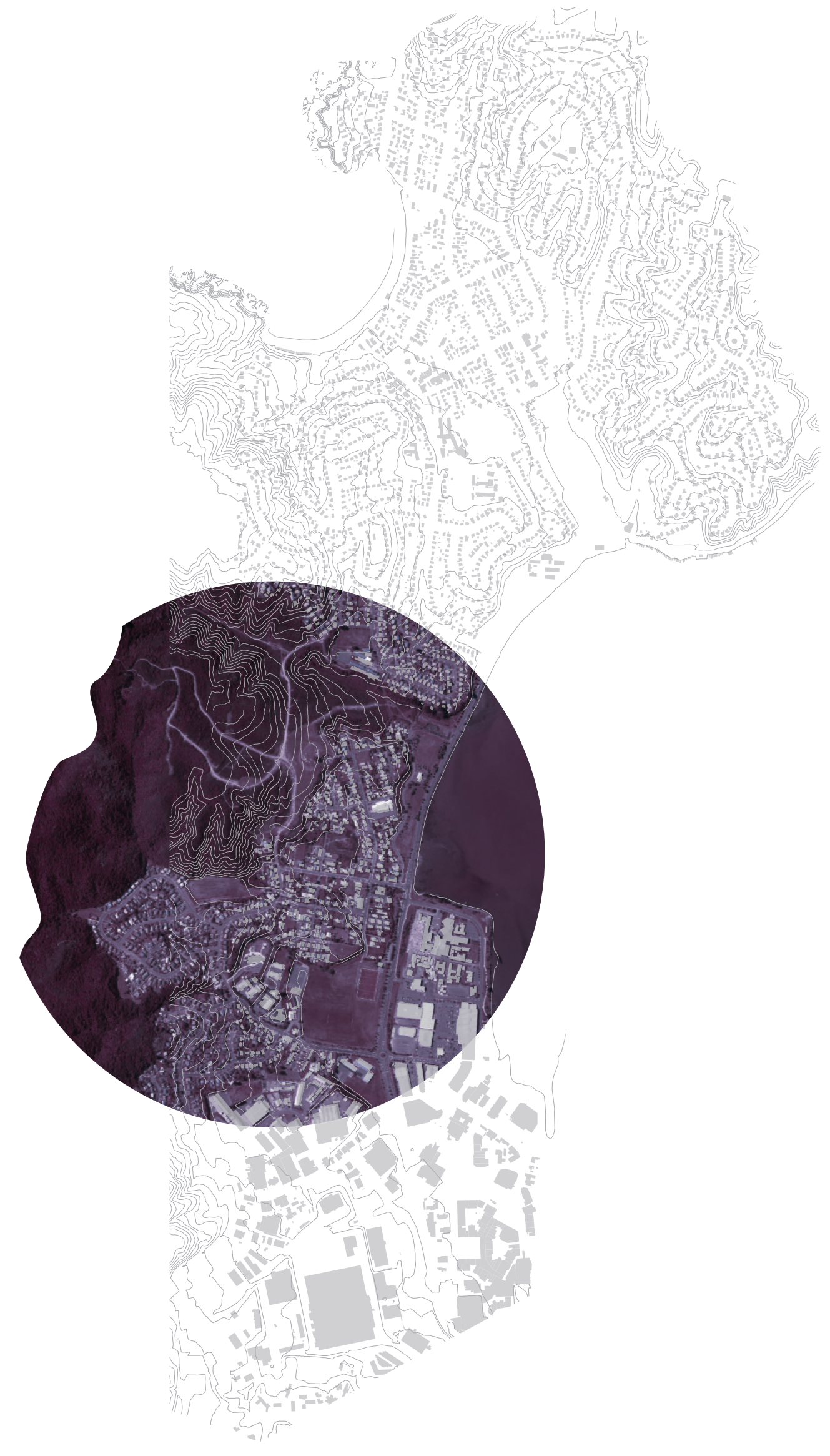


Many current community members identified that flooding is a historical and continuing issue in some streets and properties located in Takapūwāhia. This issue poses health risks

to the community and must be addressed as

the problem affects significant sites such as

the Ngāti Toa marae, kaumātua flats and also

street surfaces. The flooding has the potential

to degrade properties and streams throughout

the community (Toa Rūnanga Inc). Key areas

the northern end of Elsdon Park. These areas

coincide with Mahinawa and Takapūwāhia

Streams; therefore, the cause of flooding is

probably due to stream overflow and lack of

retention planting or wetlands.

\section{Hukatai Stream}

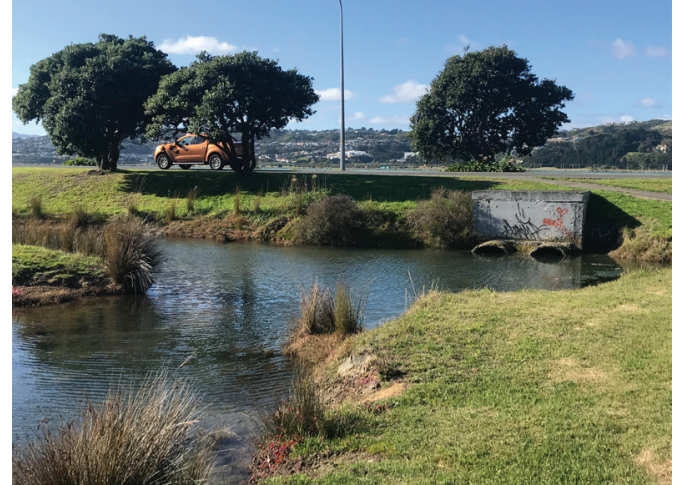

Fig. 22: Image of Hukatai Stream.

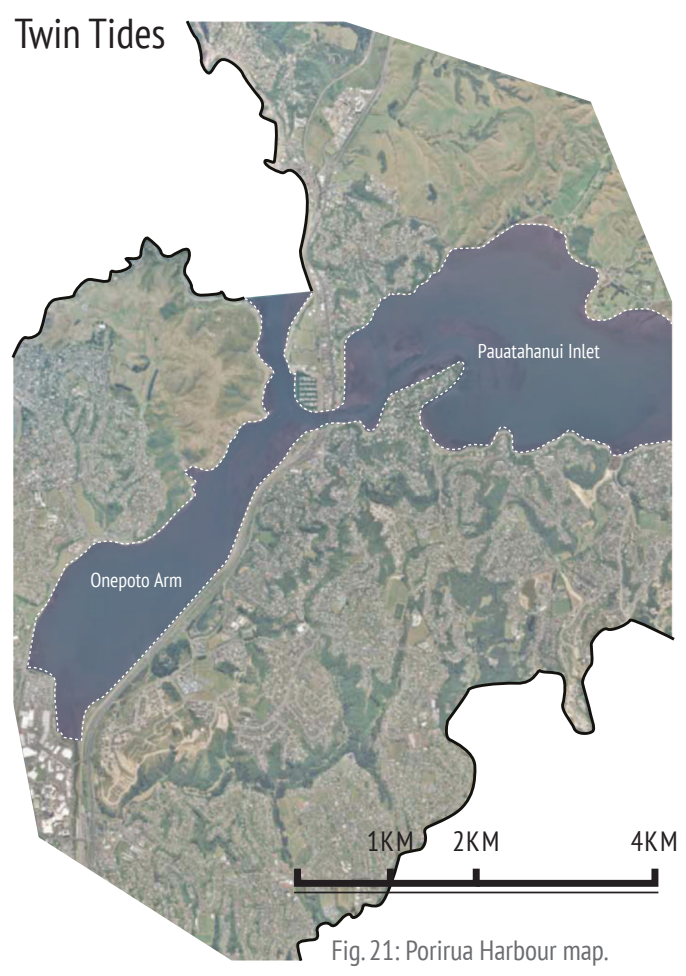

Mahinawa Stream

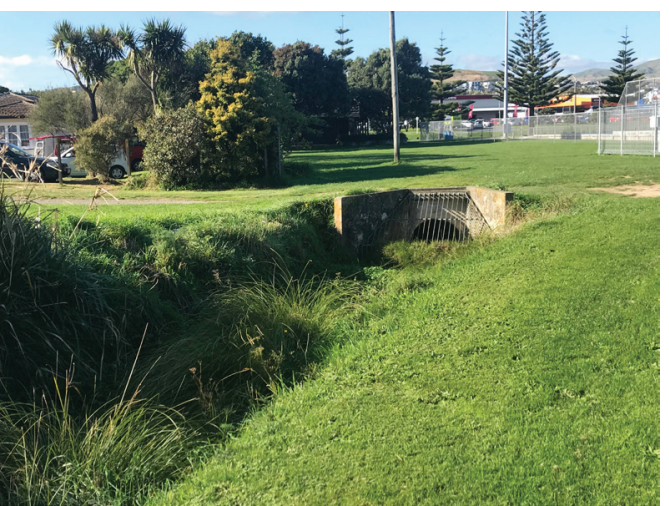

Fig. 23: Image of Mahinawa Strean

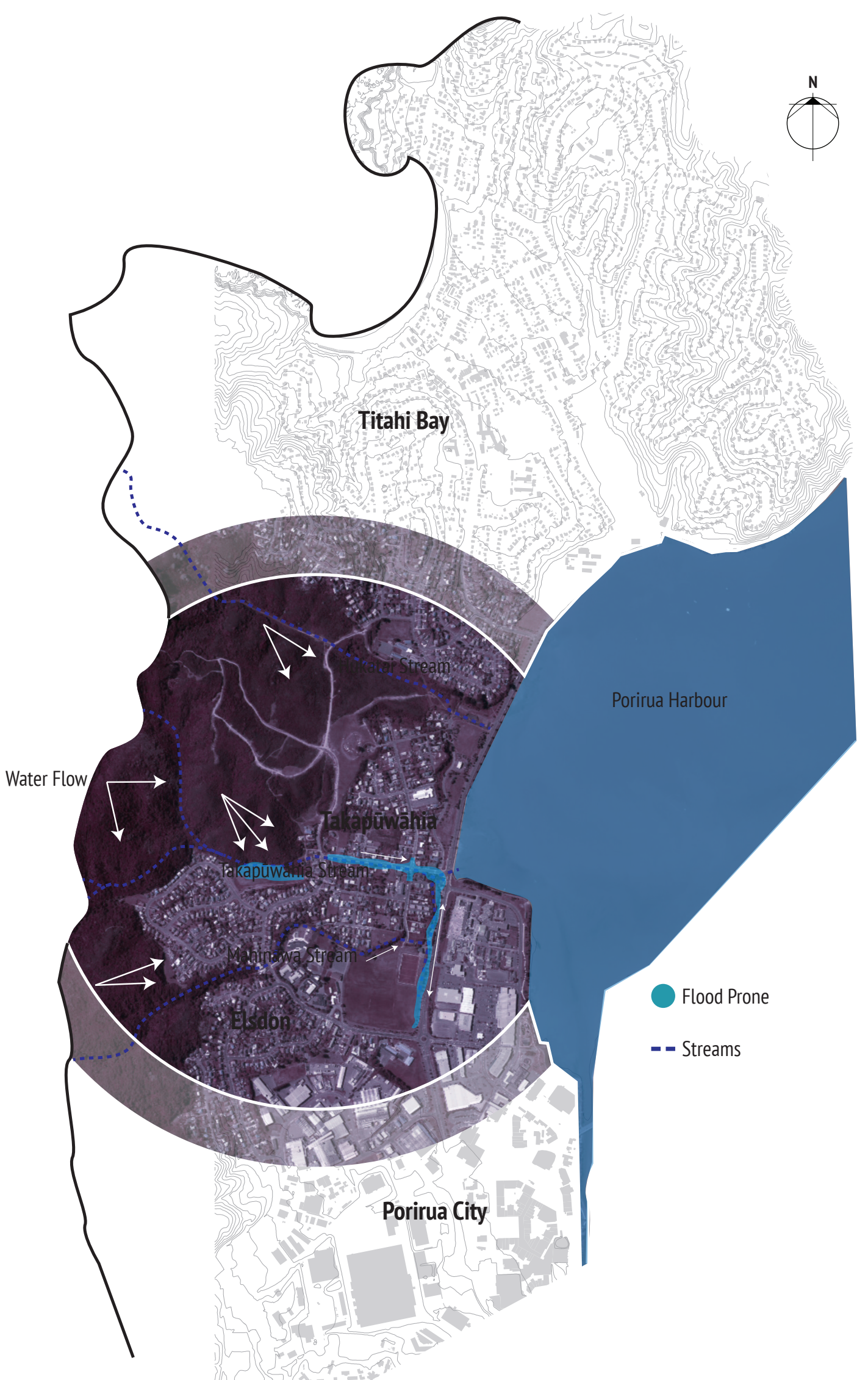

$250 \mathrm{M} 500 \mathrm{M}$ $\stackrel{250 \mathrm{M}}{\mathrm{L}}$ 


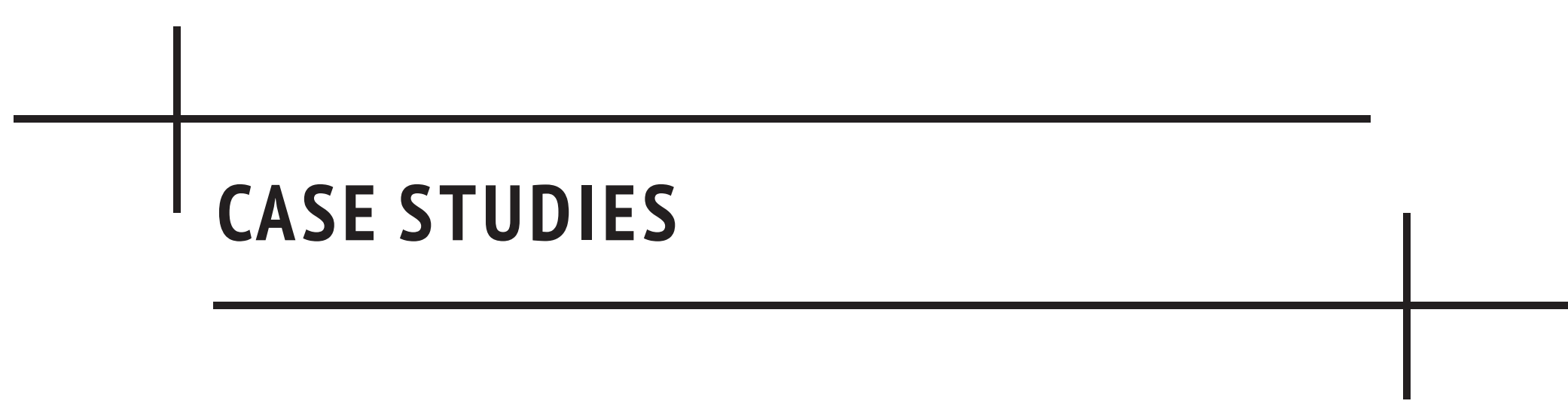




\section{Case Study 1}

\section{KOPUPAKA RESERVE}

(Maki Street, Whenuapai,Auckland 0814, New Zealand)

About:

Kopupaka Reserve provides a significant

open space for the public realm of Westgate, North-Western Tamaki Makaurau (Auckland). Through a design-led approach, Kopupaka

Reserve combines engineering, ecology and cultural values to mitigate existing stormwate problems and restore the degraded rural

Tōtara Creek catchment. The use of traditional wetlands and streams at Kopupaka Reserve, challenge various aspects and expectations surrounding the design for the new form of hybrid park. The park intends to incorporate Māori values to bring a strong sense of place and bring balance between urban growth, ecological restoration and the public space.

\section{Intention:}

Kopupaka Reserve intends to restore

and manage the projected growth within Auckland's North-West, where plans for the Westgate town centre are expected to deliver significant commercial and community

infrastructure. The Masterplan for the town centre includes streets featuring permeable paving, rain gardens and swales that integrate within a broader green infrastructure network. This allows Kopupaka Reserve to provide the backbone infrastructure for the attenuation and detention of stormwater run-off from the streets and buildings that will be developed for this significant new community centre (Auckland Council).

Design:

Four vital concepts drive Kopupaka Reserve. These concepts incorporate ecology, culture, community and engineering factors into design. The design plan consists of a skate park, a playground and a botanical weaving garden to compliment the main wetland pond. These designs also feature cycleways and connections to the town centre, industrial and residential zones to create a network through corridors and roads.

Ecological, Cultural and Social:

Mana Whenua (land authorities) gave the

name Kopupaka, which represents the meeting points of Totara and Waiteputa streams flowing downstream from the reserve. Kopupaka also incorporates Mãori ancestry within the area. The Mana Whenua landscape narrative has helped guide the design team's thinking and is expressed in interpretation signage on site. They also highlighted a traditional history of food gathering in this area, including identification of a tuna (eel) gathering site at a historical wetland.
The project has completely restored the local stream network, and created a number of stormwater and flood attenuation wetland ponds to filter and manage stormwater run-off. The creation of large areas of revegetation and riparian planting have restored native species to this area that were absent. This planting will help to manage and naturally improve water quality and significantly improve habitat across the new ecological corridor created (Auckland Council).

\section{POTENTIAL AND INFLUENTIAL}

ASPECTS

- Incorporation of Mãori values

- The use of culture and community in design

- Māori place naming

- Mãori influenced backstory

- Highlighting traditional practices

- Engagement with local iwi

- Wetland development

- Ecological awareness
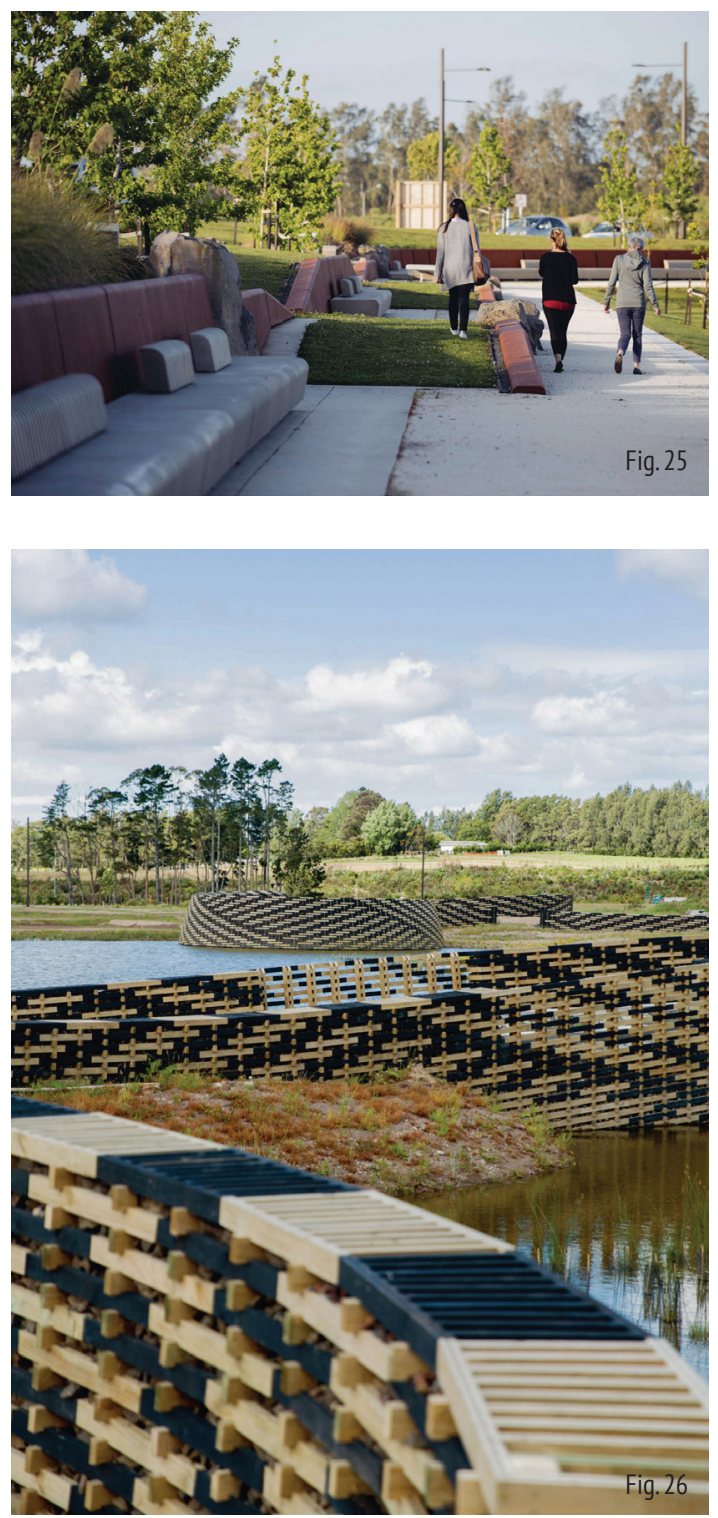

Fig. 25 - 26: Kopunaka wetland design. 


\section{Case Study 2}

SISTER KATE'S PLACE OF HEALING

(Treasure Rd, Queens Park WA 6107, Australia)

About:

This project is an example of deep listening

and the role of landscape architects in

providing a holistic 'People and Place'

approach to visioning that goes beyond

spatial design. The project demonstrates a

deep understanding of Indigenous planning,

management and cultural heritage visioning

as well as intergenerational cultural healing.

The site is significant to the stolen generation

providing a haven for those who were taken

to live in Sister Kate's Home. This home was

established in 1934 to house Aboriginal

children removed from their families and

Country across the State.

Intention:

Sister Kate's Home Kids Aboriginal Corporation

required a strategy to guide plans for their

bush block. This bush block was to represent

an important cultural place. Sister Kate's

collaborated with members of UDLA-Urban

Design and Landscape Architecture to co-

design a strategic and sustainable vision.

Design:

The vision for the bush block came to fruition

through the final spatial plan for Sister Kate's

'Place of Healing.' This plan included a public

welcome centre, an edible garden, a fauna walk, an operations building, a healing garden and an event space.

Ecological, Cultural and Social:

The spatial and organisational planning for this project provides a foundation for healing through cultural awareness, training and an all-abilities access experience. This 'Place of Healing' also pay respects to the stolen generations of indigenous aboriginal people and seeks to improve mental and social wellbeing and this intends to help counter intergenerational trauma and feelings of disempowerment. The project represents an exciting opportunity to walk and work together to reinforce indigenous cultural identity, to heal and to share their cultural strength with the broader community (AlLA).

\section{POTENTIAL AND INFLUENTIAL}

\section{ASPECTS:}

'People and Place' approach

- Understanding of Indigenous planning,

management cultural heritage

- Site significant to Indigenous people

- Representation of cultural place

Create healing through cultural awareness

- Improve mental and social wellbeing

- Work with and learn from Indigenous

community
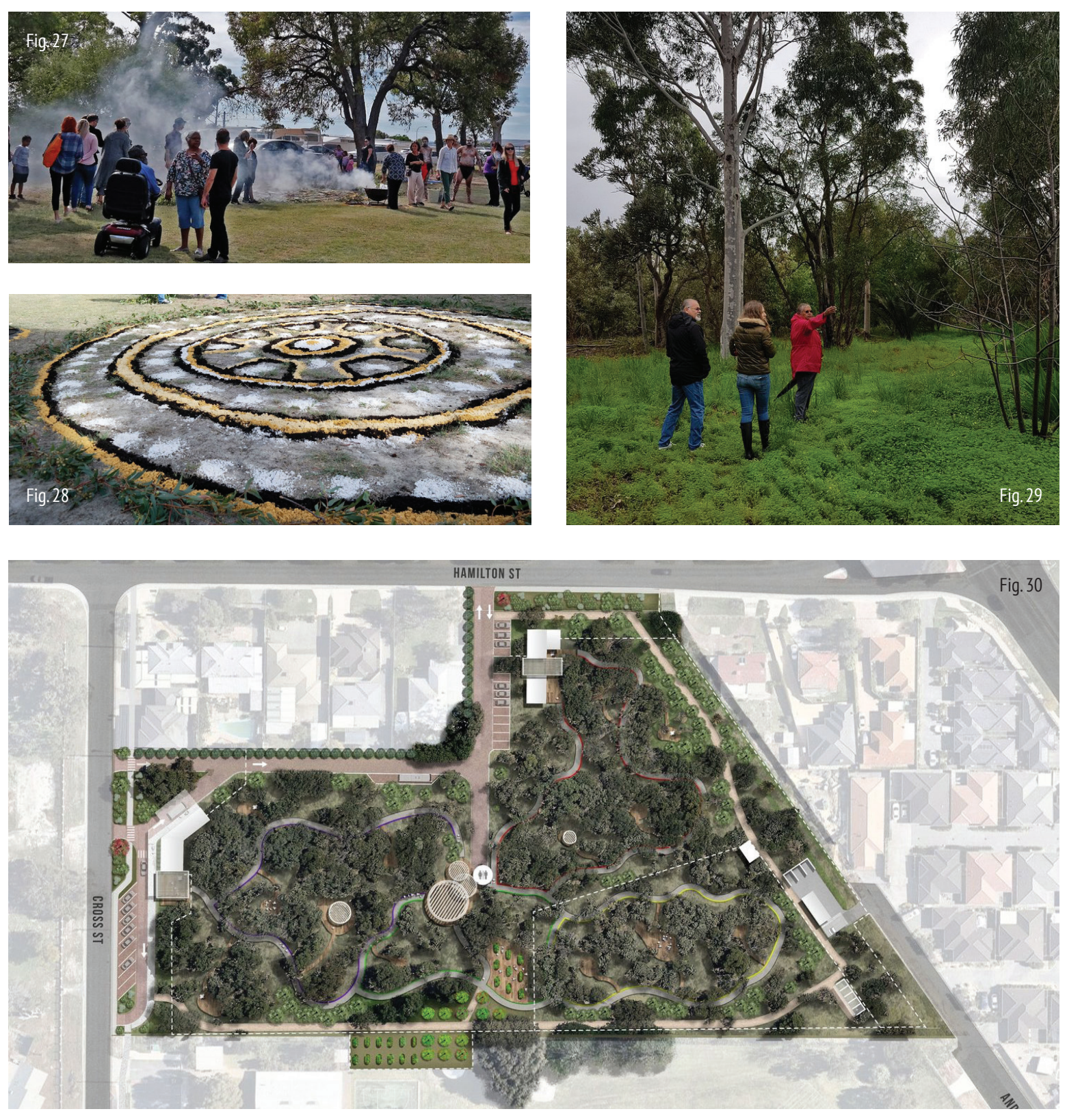

Fig. 27 - 30: Sister Kate's place of healing 
LA ROSA RESERVE STREAM

\section{DAYLIGHTING}

(La Rosa Street, Green Bay, Auckland 0604, New

Zealand

About:

La Rosa Reserve is located in Green Bay, West Auckland and looks at bringing buried pipes to the surface through forms of

stream daylighting to restore natural order in the waterways. The idea of naturalising

the streams offer many benefits to the

environment and the community. The project was initiated and managed by the Auckland Council Stormwater Unit, with Boffa Miskell as Design Managers, working closely with

EDC as engineering design consultants. HEB

Construction undertook the physical works,

and Auckland Council's Sustainable Catchment team managed community engagement (Boffa Miskell).

Intention:

La Rosa Reserve intends to incorporate natura systems to existing underground piping. The aim is to achieve restoration of natural streams with the goal of re-establishing habitats, enhancing stormwater management and encouraging community engagement.

Design:

Two tributaries of the Avondale Stream were daylighted from their culverts for a combined $200 \mathrm{~m}$ length. La Rosa showcased bioengineering techniques for stream

restoration and illustrated how a community could reconnect with their local stream (Boffa Miskell).

Ecological, Cultural and Social:

Community and Iwi were active partners, embracing the project in early engagement, and involved through community artwork, planting design and installation, pa harakeke, and orchard design and installation. The local community have taken ownership of the project, with local schools, day-care centres and special needs facilities using the reserve as an outdoor classroom, and community groups undertaking fish surveys, planting, and ongoing care of the stream (Boffa Miskell).

\section{POTENTIAL AND INFLUENTIAL}

ASPECTS:

- Restoring natural waterways

Create opportunities that benefit the environment and the community

- Encourage community engagement

- Enhance stormwater management

Reconnect people with place

Community driven design process

- Landscape architecture awareness in the community
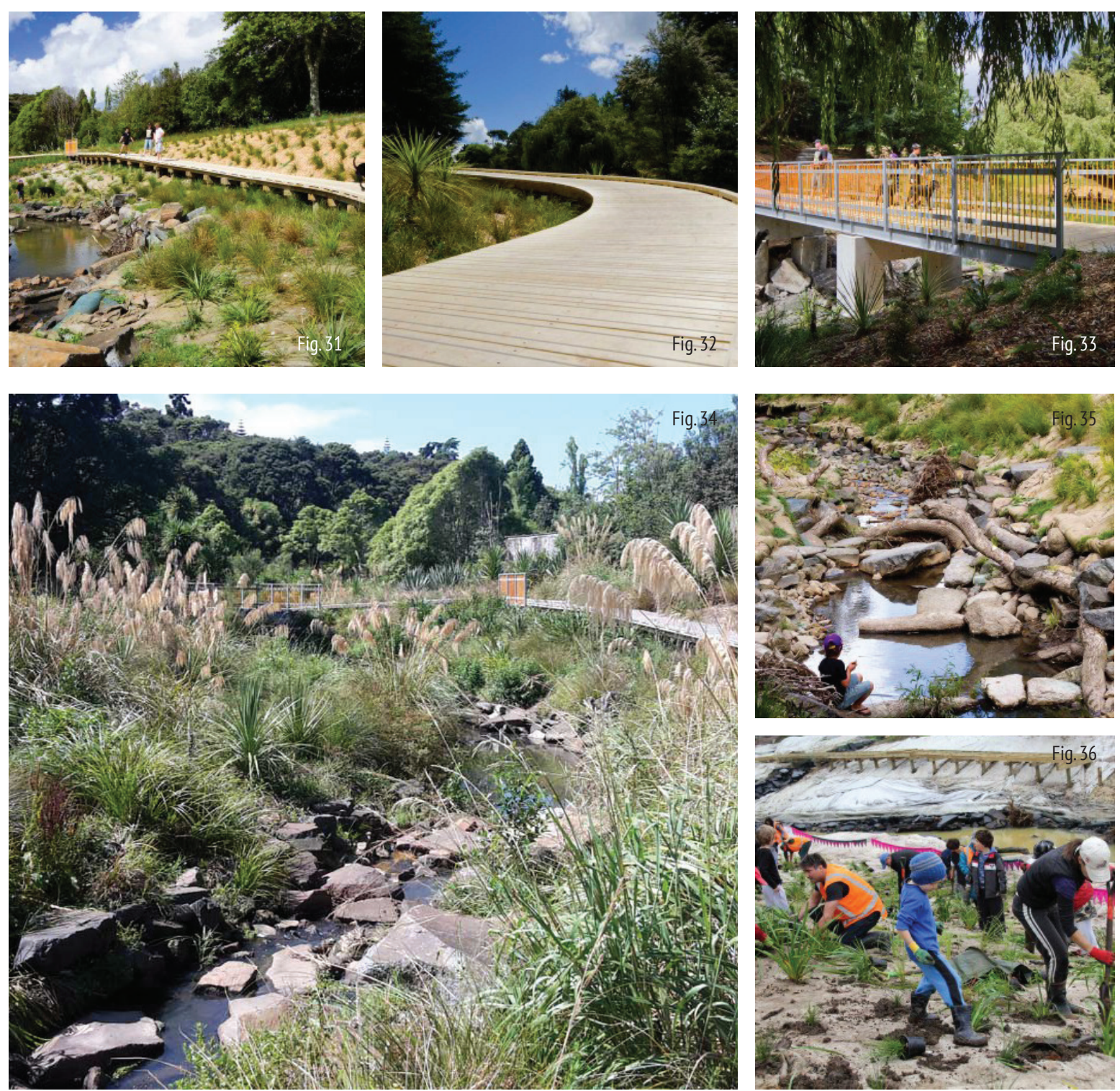

Fig. 31 - 36: La Rosa Reserve stream and pathway connections. 


\section{Case Study 4}

\section{PUHI KAI ITI/COOK LANDING}

(Inner Kaiti, Gisborne 4010, New Zealand)

About:

The first landing place of James Cook in New

Zealand in 1769 is commemorated at Puhi Kai

Iti/Cook Landing Site National Historic Reserve.

The site is believed to be within a short

distance of the actual landing site, and not far

from Te Toka a Taiau, where the first significan

meeting between Māori and Europeans took

place. The landing site is now located on

reclaimed land close to the edge of the Pacific Ocean. This is now beside Rakaiatane Road an has changed significantly since Cook's arrival.

The old shoreline is still represented through dark tiles to mark the previous location. The site was also the first landing place of the Horouta and Te Ikaroa-a-Rauru waka (canoes) which carried Māori to the district (Atawhai).

Intention:

The Gisborne District Council reached out to Boffa Miskell to develop a design scheme for the redevelopment of the significant landing site in Gisborne. The initial project scope looked at telling a story in conjunction with Ngāti Oneone, that entails storytelling and historical and cultural narratives through landscape architectural design. The project was to include the development of a new pedestrian bridge connecting to Taumata 0 Titirangi. The bridge is of a circular design and will contain cultural and historical narratives relating to the 1000 years of navigation to

New Zealand (Miskell Puhi Kai lti / Cook

anding Site Historic Reserve Redevelopment).

Design:

The Puhi Kai Iti/Cook upgrades and narrative

include:

- A sculpture acknowledging ancestor Māia and his arrival on the Te Ikaroa a Rauru waka.

Sculpture to depict hue (gourds) that Maia was skilled in cultivating.

-Nine pou to represent the men shot in the

encounter with Endeavour crew.

Strengthening of the cenotaph

Excerpts from the diaries' of Cook and his crew.

- Drawings by botanists from the Endeavour, Banks and Solander.

- Discs symbolising pennies donated in the

national fund-raising effort by local children to build the monument.

History of the development of the port.

Construction of circular walls featuring the most extensive tukutuku panels in the world take shape at Puhi Kai Iti Cook Landing Site. One hundred and twelve steel tukutuku panels, punched with 53,900 single holes have been woven with $7.3 \mathrm{~km}$ of cord by volunteers from Ngāti Oneone and DOC, Gisborne District Council and other skilled weavers from around Tairawhiti. Nick Tupara, Ngati Oneone artist and representative, developed the woven designs incorporating patterns kaokao, poutama roimata tōroa, pātiki and patterns specific to Te Poho o Rāwiri Marae. Mr Tupara said it has been a physical challenge because of the sheer size, scale and materials of the tukutuku -

steel and rope - compared to harakeke and slat board (Tairāwhiti).

Ecological, Cultural and Social:

The original guardians of Puhi Kai Iti are Ngāti Oneone. Ngāti Oneone have a strong connection to this place, but over time and through historical events, this connection has been challenged. The project aims to restore that strong connection and deliver on the aspirations of Mana Whenua.

The use of tukutuku in the design of the wall will encourage people to come, enjoy the site and understand what's happened here over a long, long period. Tukutuku was used by Mãori to bind materials for houses, and the same techniques were used in waka that navigated to Aotearoa New Zealand."In weaving you get to exchange with anothe person with a barrier between you, and together you offer materials through that barrier and create something quite beautiful at the end" says Mr Tupara. "The space aims to balance the historical narratives of the region, bind a sharing of stories, history and heritage, to bring together our shared differences" (Tairāwhiti).

\section{POTENTIAL AND INFLUENTIAL}

\section{ASPECTS:}

Commemorate historical figures and

influential journeys

-Representation of Māori through symbolism and Māori influenced design

- ntail storytelling and historical and cultura narratives through design

sculptures that acknowledge influential people

-Design nfluence by traditional Māori practices such as carving and weaving

- Incorporate iwi artists and skilled weavers

- Relate design to significant plants

-The use of tukutuku in design 

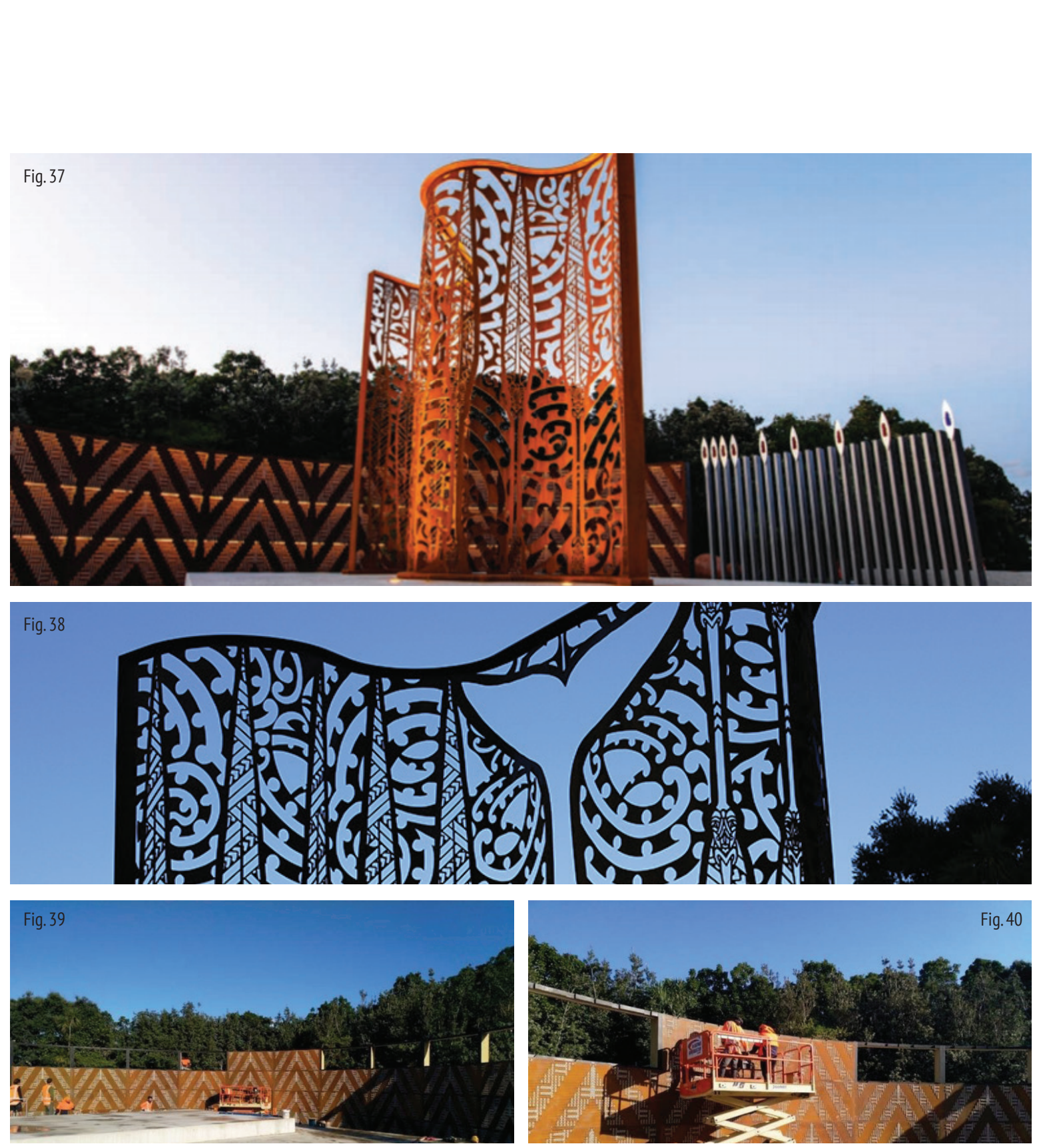

Fig. 37 -40: Puhi Ka itti cultural symbolism designs

\section{Case Study 5}

\section{FREYBERG PLACE}

(Auckland CBD,Auckland 1010, New Zealand)

About:

Freyberg Place is a small town square located in Auckland. It is named after Baron Freyberg who was a prominent soldier and the first New Zealand-raised Governor-General of New Zealand. This public space explores the overlaps between public art and architecture; it offers an open invitation for Aucklanders to inhabit, occupy and claim for themselves. Freyberg Place is one of a small group of public open spaces within Auckland's city centre. Set within a network of laneways, it is a popular lunchtime destination - a breathing spot in faster-paced surrounding streets - and now, a flexible space suitable for performances, markets and other activities. In a towering inner-city, Freyberg's due-north orientation allows for much-needed, sunny and sheltered area in the city (Isthmus).

\section{Intention:}

The upgrade of Freyberg Place intends to deliver a more vibrant, accessible and liveable city for the people of Auckland. This is achieved by elevating the space from just an inner-city space to a premium square that incorporates art, landscape and buildings to the open space (Isthmus).
Design:

The design of the new plaza is based o artist John Reynolds' narrative 'One hundred and eighty-nine steps' - a design that sees myriad and intersecting flights of steps and terraces applied to the square's banked edge. Here, the ubiquitous flights of steps often found throughout the city are amplified and magnified into 'flows' that might have cascaded down the slopes of nearby Albert Park.

At Freyberg Place, the horizontality of the step modules is balanced with active vertical elements, nīkau and light poles, uplifting notes that tie back to the expressed concrete columns of the refurbished Ellen Melville Centre. Deliberately, the hall, plaza and steps were envisioned as a connected palette of contrasting textures: the landform of stair and terraces, for example, juxtapose with the fine grain and colour of the plaza paving. Within the rhythm of elements, the stairs ebb and flow, protruding pointedly out of the landscape from some angles; nestling in from others. From above, light diffused by groves of pōhutukawa and nīkau adds to the drama by drawing intricate and dramatic shadows across the steps (Isthmus). 
Ecological, Cultural and Social:

As a result of Mana Whenua consultation during early design phases at Freyberg Place,

a bright and meaningful strategy around

stormwater management, materials and

planting was developed. The importance of the

water that once flowed through the area has

been acknowledged and expressed in the work

by Ngāti Whātua Ōrākei artist Graham Tipene.

The artwork has been water-jet cut into stone,

forming a channel for water to flow after

emerging from the ground in a cluster of jets.

These engraved patterns are representations

of the water flow through Māori symbolism

(Isthmus).

\section{POTENTIAL AND INFLUENTIAL}

ASPECTS:

- Create an open and welcoming environment

- Incorporate native vegetation

- Use of traditional Māori materials for design

features

- Understand the significance of past natural

environments and incorporate into design

- Tell a story through and with the local iwi

- Engrave patterns that represent Māori

symbolism into surfaces and designs
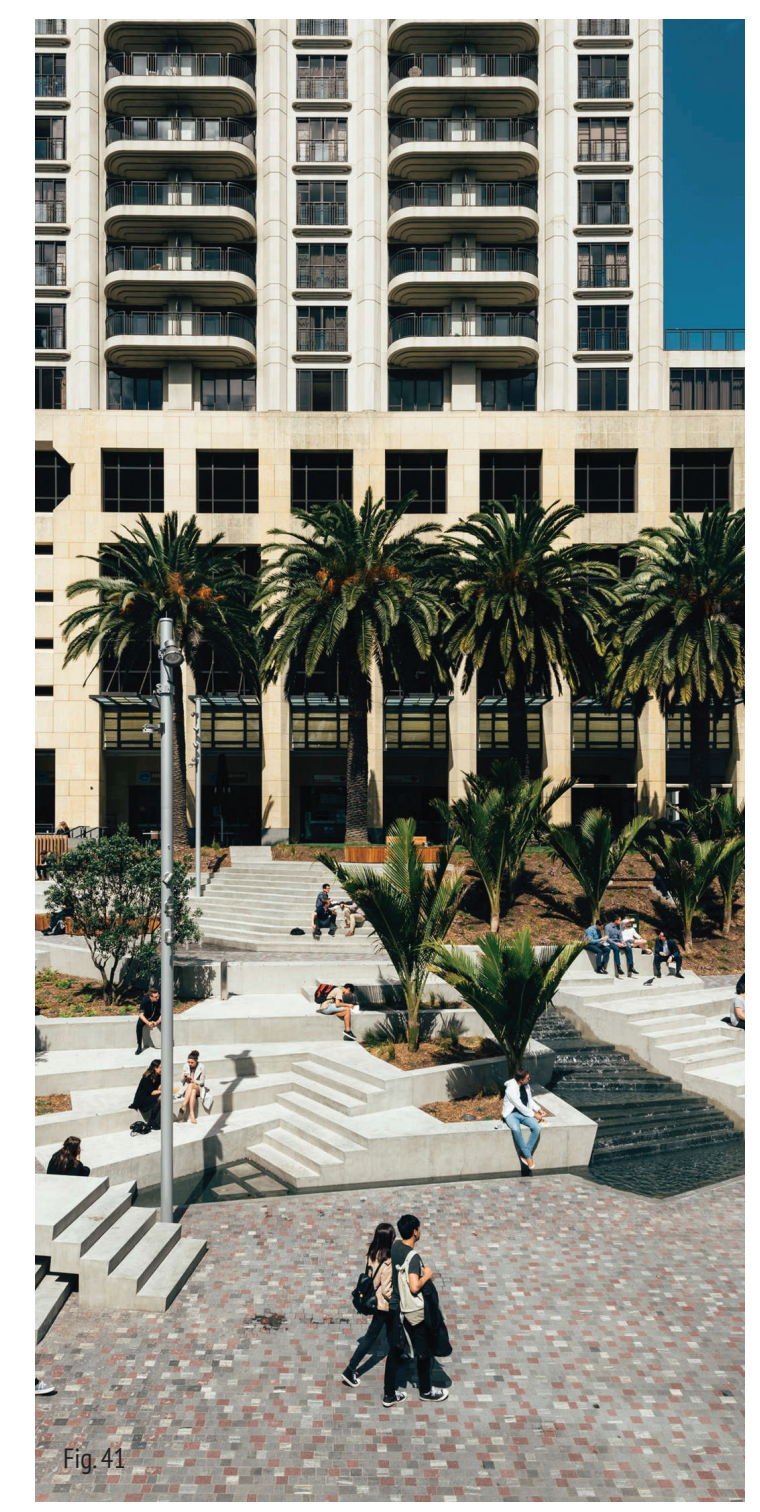
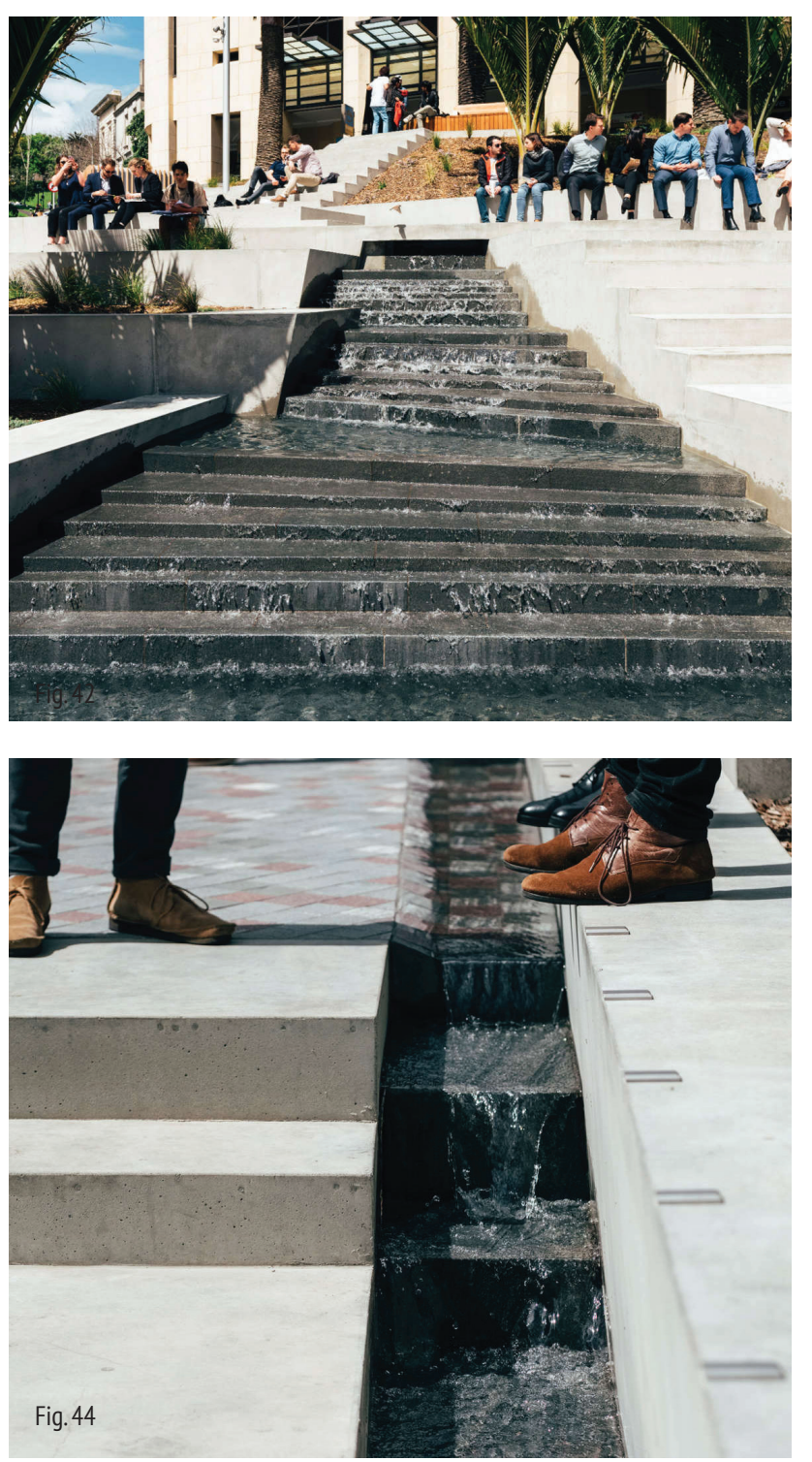

Fig.41 - 46: Freyberg Place public space, water features and cultural design
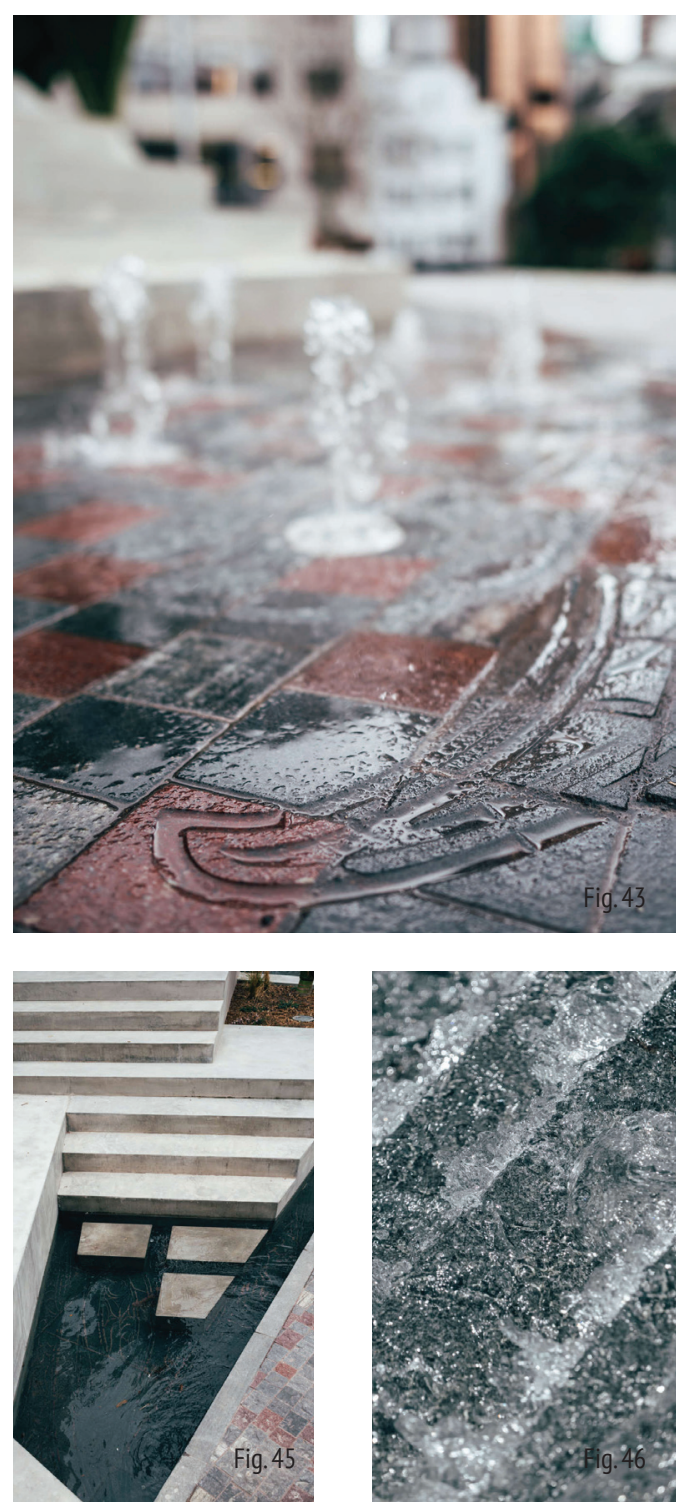


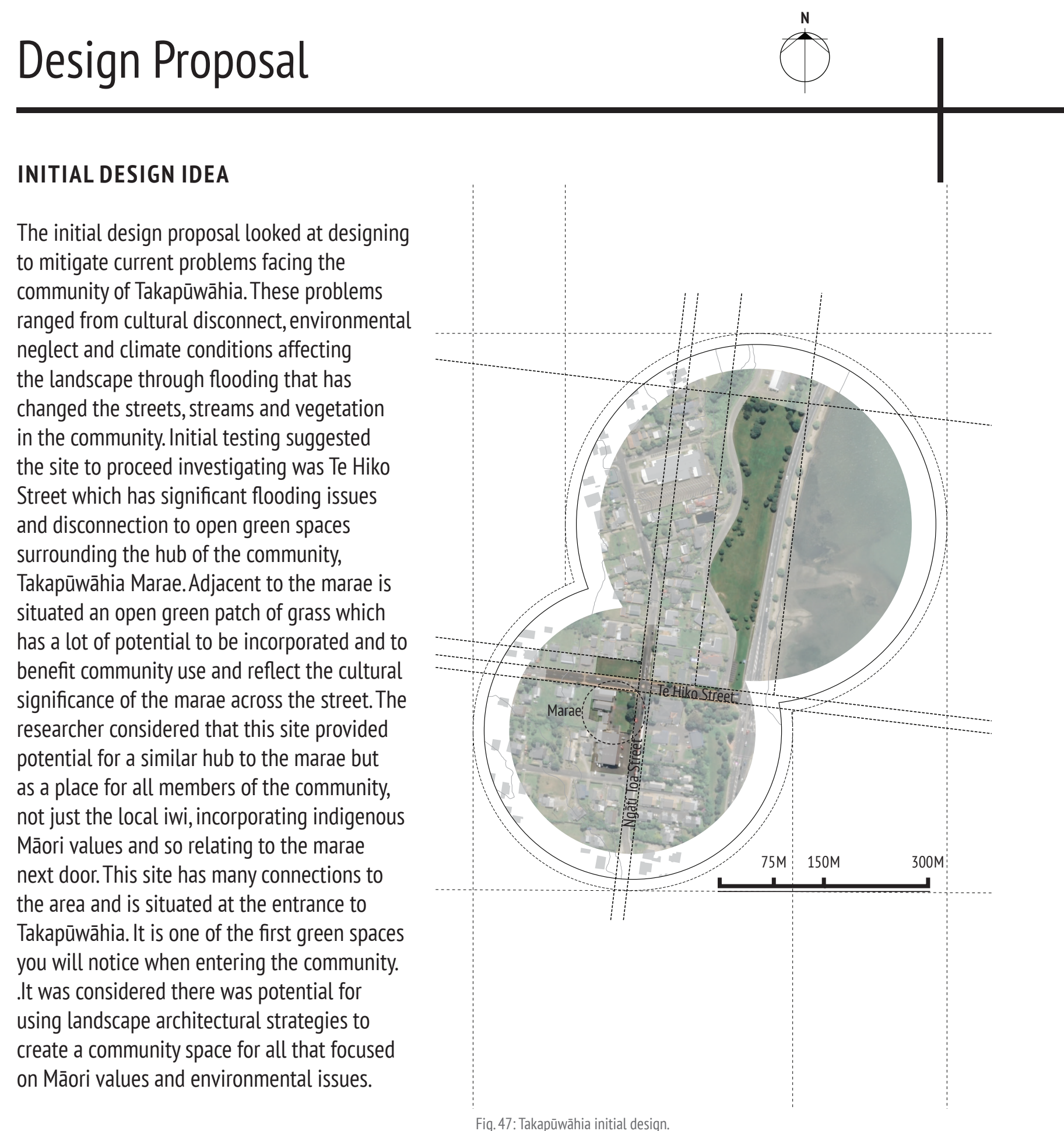

DESIGN FRAMEWORK 


\section{\begin{tabular}{l|l} 
& \\
\hline SITE ANALYSIS
\end{tabular}}

The initial designs for the open green space on Te Hiko Street, looked at adding an

outdoor hub with a cultural vibe that would have significance to the Ngāti Toa iwi while being used by all members of the diverse community. Initial design ideas looked at incorporating vegetation to address flooding issues while giving life and presence to the space. The integration of vegetation will

complement the marae style features, such as, a waharoa (gateway entrance) and an outdoor wharenui (meeting house) to relate to the similar features of the Takapūwāhia marae.

The waharoa would represent an entrance into the Takapu have a design and symbolism unique to the Ngāti Toa iwi. The incorporation of an outdoor space that represented a wharenui was

challenging because a wharenui is a sacred place for Māori people, and there is particular protocol for being welcomed on to a wharenui. Therefore, the challenge was to make this informal meeting place diverse and usable for all members of the community without the traditional protocol of the marae but still showing respect to the traditions. The aim was for this meeting place to have something of the feeling of the traditional space but be a public space for everyone to access

and connection to and to feel at home with outdoor seating, water features and gardens.

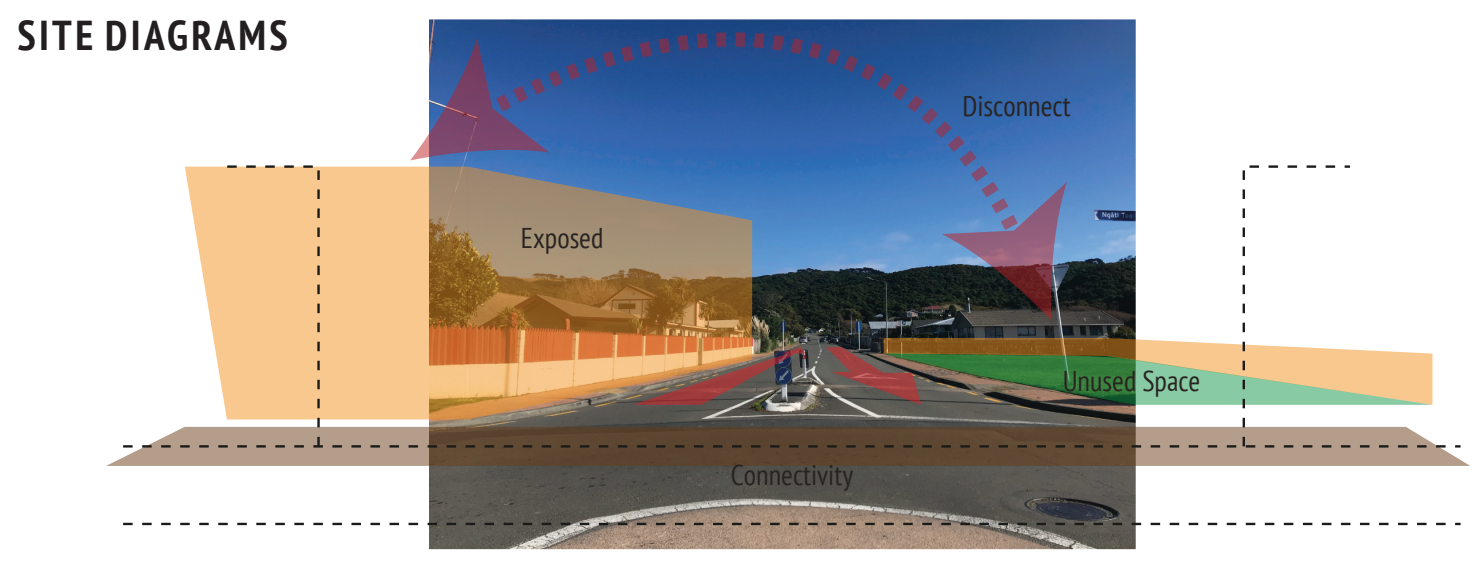

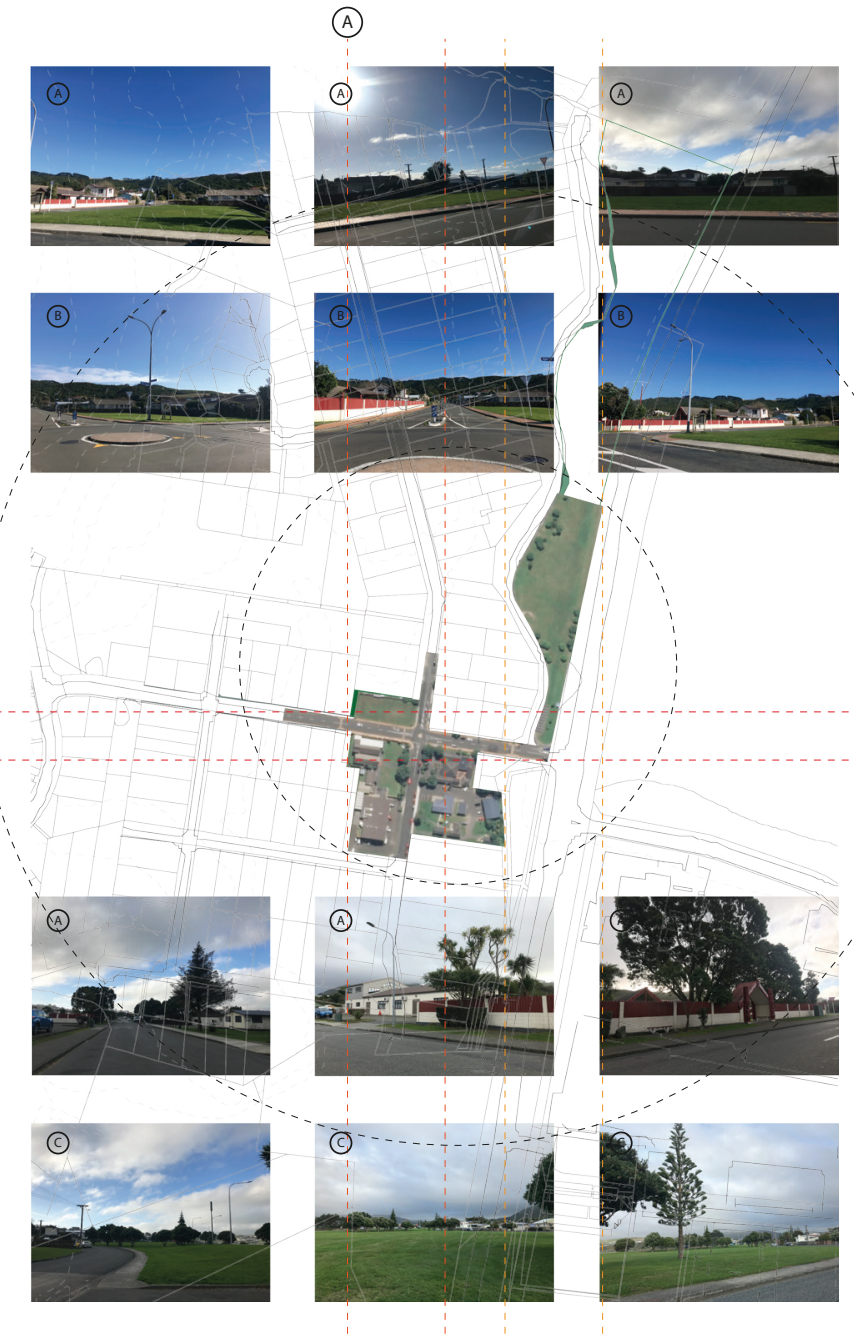

○
Fig. 48: Takapūwähia site photos diagram

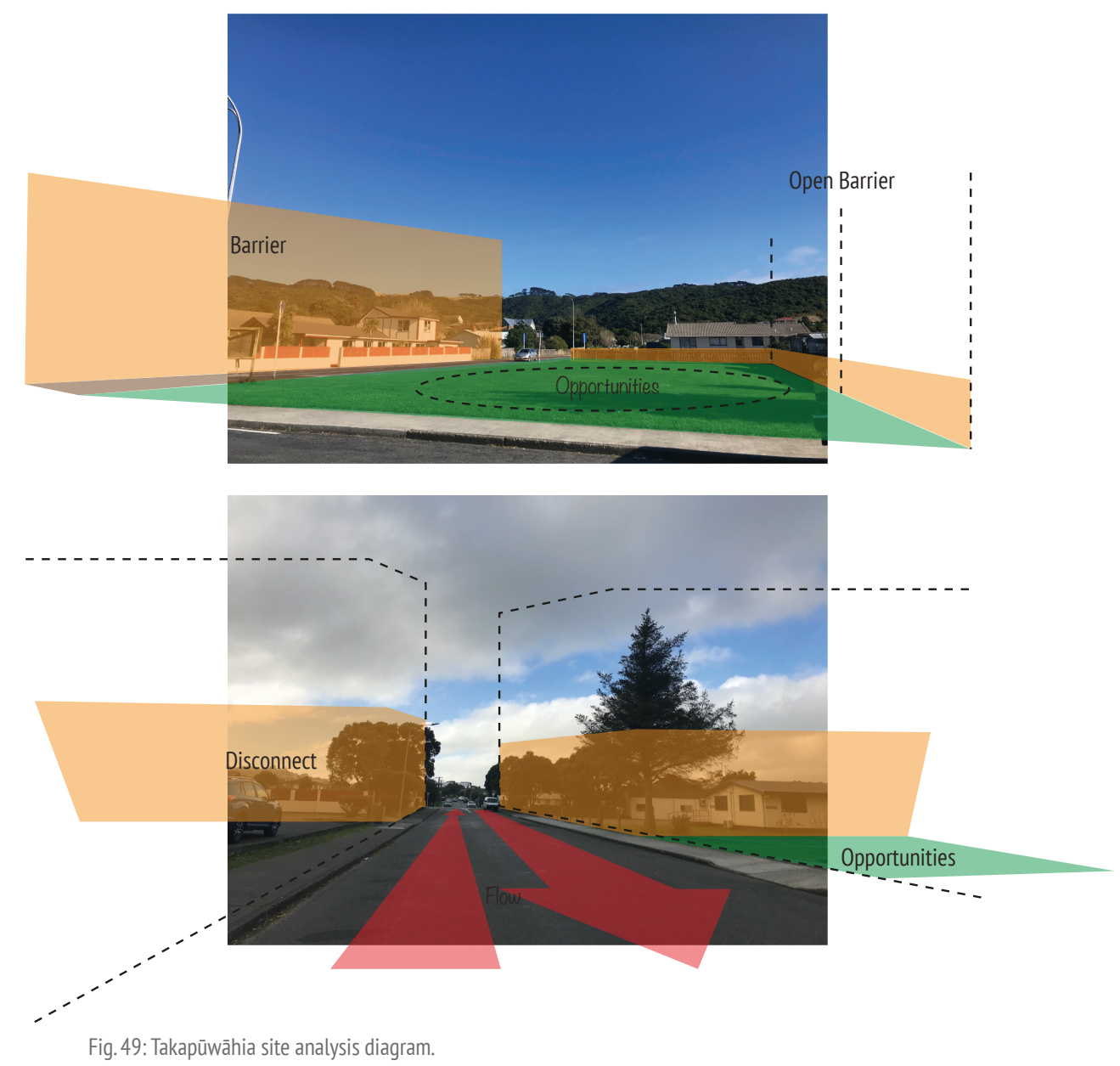




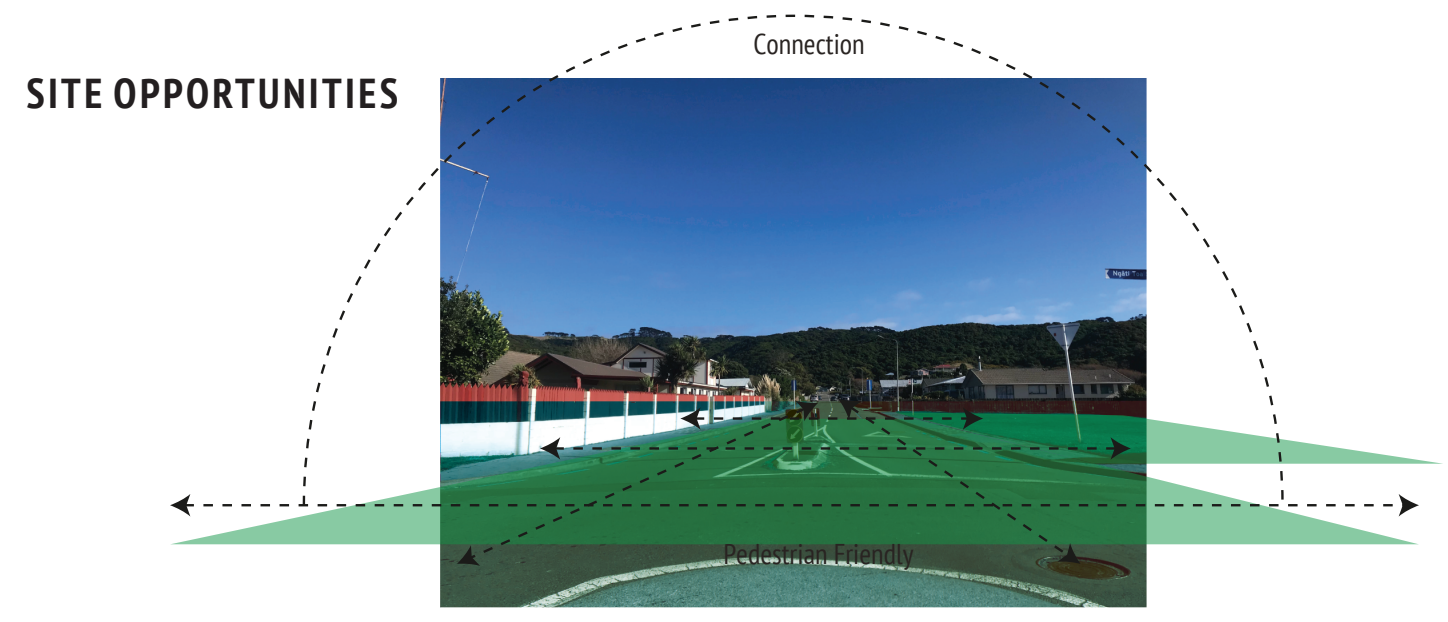

\section{STREET DESIGN}

Te Hiko and Ngāti Toa Streets are the two streets that border the selected site and the Takapūwāhia Marae The major challenge for these streets is flooding, as well as not being inviting and a lack of pedestrian friendliness. Te Hiko Street leads to the site from Titahi Bay Road. This street is the first point of entry into the community of Takapūwāhia and so it is the critical point of focus for looking at ways to welcome people into the Takapūwāhia community. This welcoming should represent the cultural values of Ngāti Toa through symbolism and address current flooding issues plaguing the community and the streets. The idea of creating a vibrant and functional street design to achieve environmental and pedestrian friendliness starts with providing a connection between the road, the selected site and the surroundings, to bring life and cultural significance of the Ngāti Toa iwi and the

street. This notion can be achieved, with the introduction of planting beds located between the footpaths and the road, that would create life on the street and allow connection

to the selected space. The links would be enhanced with native plants of importance to Māori people, such as, harakeke (Phormium cookianum) integrated into planting beds and public gardens. Plants such as oi oi (Apodasmia

similis) and toetoe (Austroderia) will be incorporated which are beneficial for water retention and filtration, which will help mitigate the flooding problems. The existing roundabout may not be coherent with the dea of having a permeable paving surface, therefore the roundabout is likely to be removed.

Creating a welcoming feel into a community consists of various aspects, ranging from cultural relevance to surface materials. The street design needs to make users feel welcome. The idea of pedestrian friendliness is an essential factor to consider. It allows the street to provide welcoming, while giving the space life by creating a connection between the people and the place. Pedestrian friendliness is achievable by enabling pedestrian control over the space. For instance, a simple but effective change to surface materials will give the sense of pedestrian hierarchy and spatial connectivity. The introduction of different surface materials will provide pedestrians with the freedom to connect to the space of the marae and the new public site. The pedestrian hierarchy will be enhanced, with the slowing of vehicle traffic due to surface changes. Taking the dominance of vehicle traffic away from the street will allow a safe passage for pedestrian users and provide a stronger connection between the marae and the site. 
SITE POTENTIALS
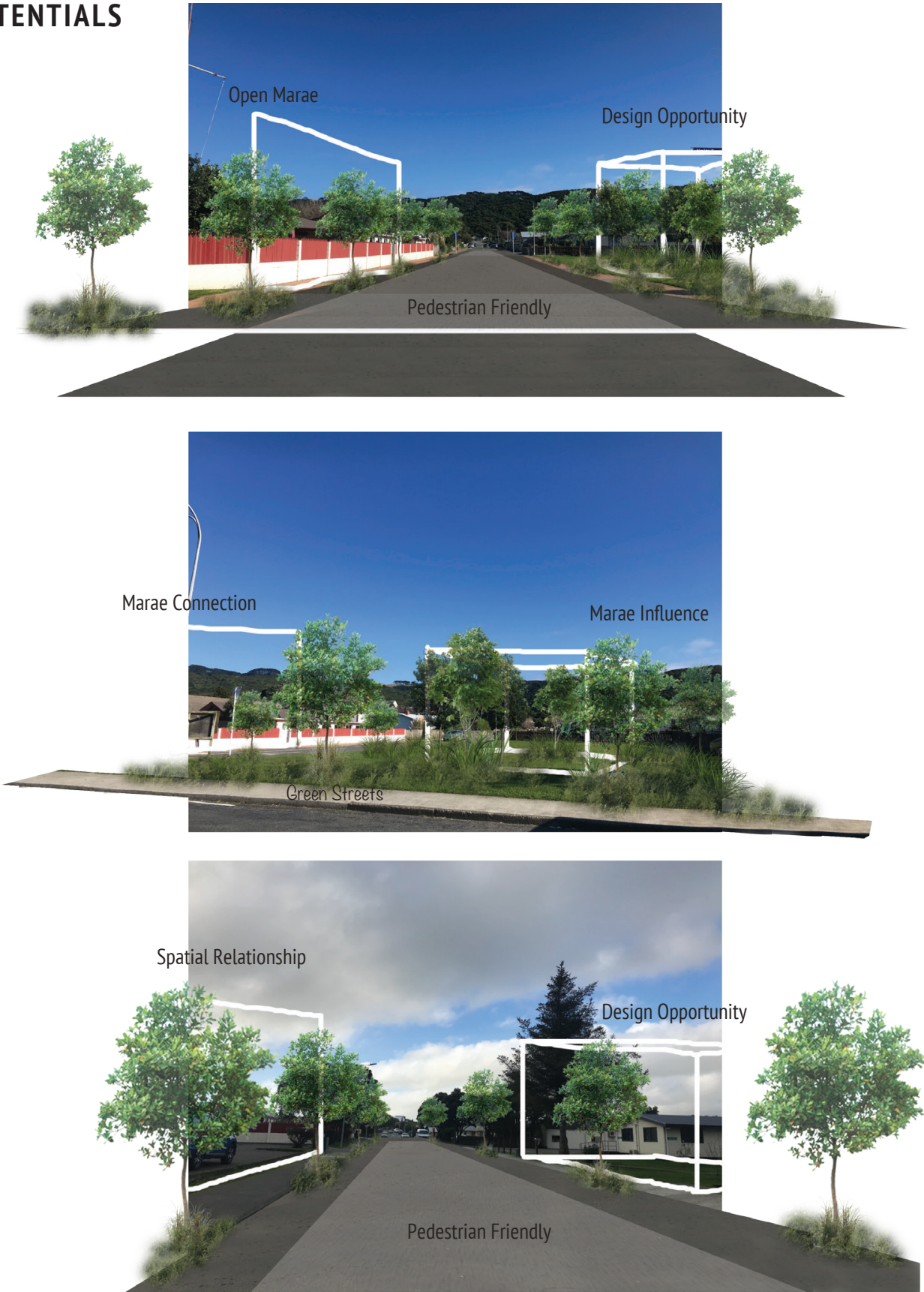

Fig. 51: Takapüwähia site potential diagram

\section{WHAT'S NEXT?}

ENGAGE WITH COMMUNITY / PARTICIPATORY DESIGN PHASE / PRESENT

ANALYSIS / ASK QUESTIONS / ACCUMULATE COMMUNITY IDEAS 


\section{Participatory Design}

PHASE ONE

The initial design phase was complete, and it was now time to test the analysis, research findings and design ideas with the community.

The initial step was followed up with the

participatory design phase. The participants were members of the Ngāti Toa iwi, in

particular, members of Rangatahi Wānanga Reo (youth group) and Te Rūnanga o Toa Rangātira

(iwi authority and administration group).

The session was located at the heart of the

community, in the Takapūwāhia Marae, which

is a place of aroha, welcoming and hospitality.

The members of the Rūnanga were facilitators

providing stationery, a projector and food

for the participants at the conclusion of the session.

The session started with an introduction

that explored findings and analysis of the

Takapūwāhia community focusing on the

existing environmental and cultural issues that

the design proposal would aim to address to

enhance environmental and cultural identity

within the community.

Following the introduction, the participants were asked to contribute their thoughts and ideas on existing conditions and issues.
Introduction

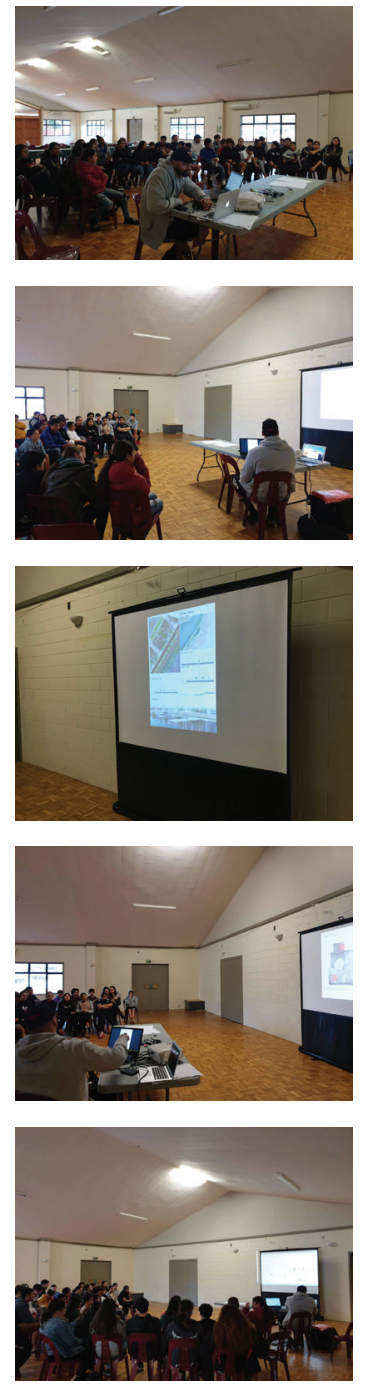

Fig. 53: Participatory Design introductio 
The participants were split into small groups and given analysis maps of the proposed site to further their knowledge of the site and draw out their thoughts and ideas. Their initial engagement with the site was shown through drawings of their views on blank pieces of paper. The use of a blank canvas allowed them to convey their thoughts through pictures and diagrams. After this thought process, the groups were asked to come together and present their collective findings, the three or four most favoured ideas for the site and the community. The participants delivered many valuable ideas and identified issues that the researcher had not yet discovered. They proposed that the current site of focus was not the most in need of assistance. The site they identified as most in need of intervention was located just 20 metres from the original site, on the corner of Te Hiko Street and Titahi Bay Road. The piped Takapūwāhia and Mahinawa Streams meet at this site. The catchment

system is not a natural system, it is degraded and vulnerable to flooding and stormwater toxins. The participants suggested this was the place that should undergo an overhaul. This meant further analysis needed to be done to understand the issues and acknowledge the potentials for this site.
The participatory design session provided many great ideas and provoked crucial changes, changes that created greater opportunities for enhancing cultural and environmental aspects. The shift in site was a minor obstacle, but very appropriate and a pivotal step in the right direction for this project. The challenges became much more evident, yet much more exciting, as the participants showed a lot of passion and concern for their community. The change in site was a smooth transition as it was in the same vicinity as the previously analyzed site, the street connections were similar and the cultural relationship with the marae remained the same. Therefore, the task was now to collate the ideas of the participants and further analyze the new site to achieve a stronger environment and community.

To conclude, the overall experience of the participatory design session was very valuable. The participants showed they valued their tight-knit community and they were excited about the changes discussed. They were now on board and expressed interest through their enthusiastic response to the session and the ideas and designs they put forward to improve their community and environment.
Design Exploration

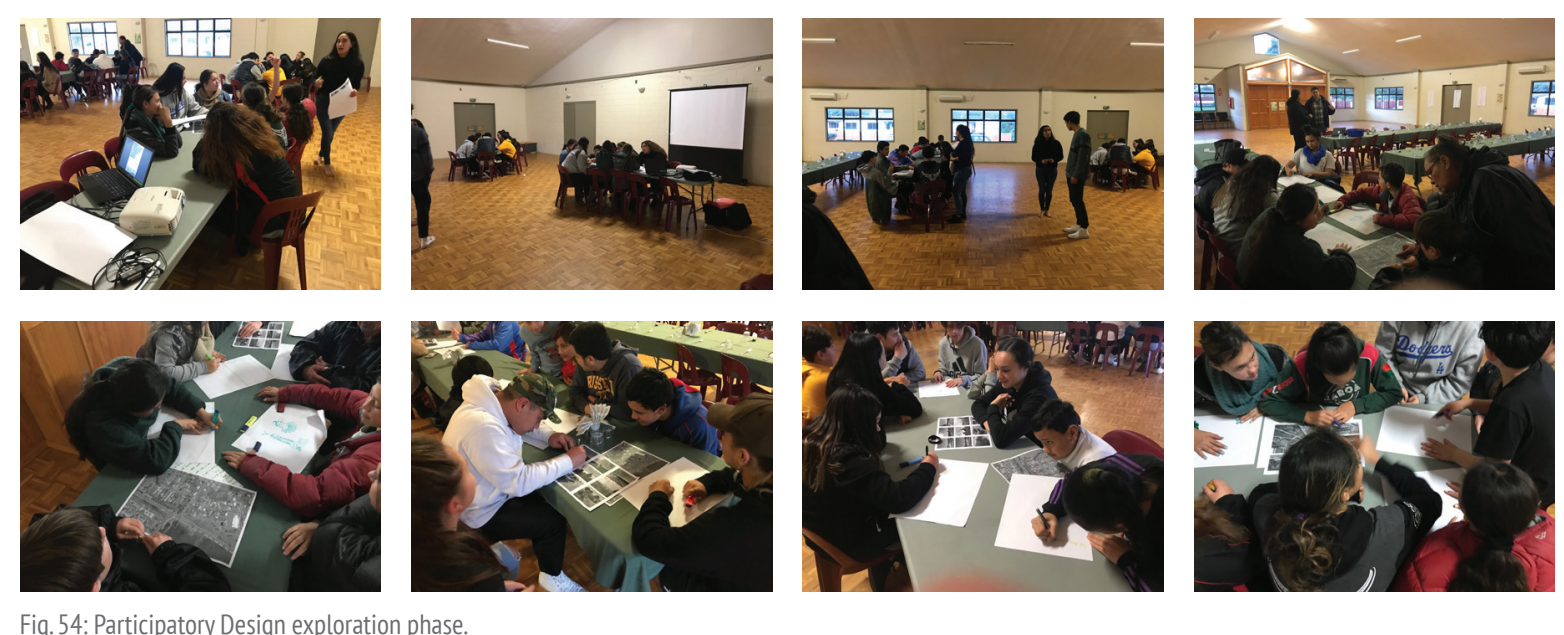

Presentation
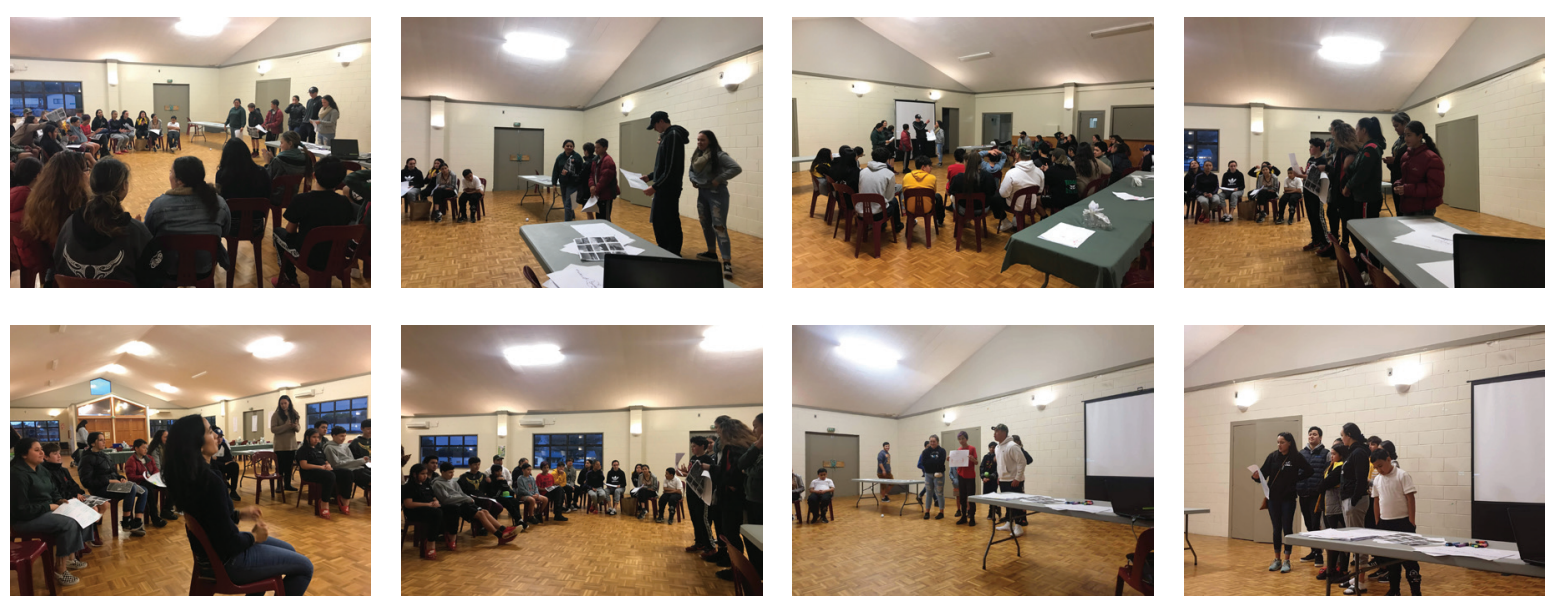


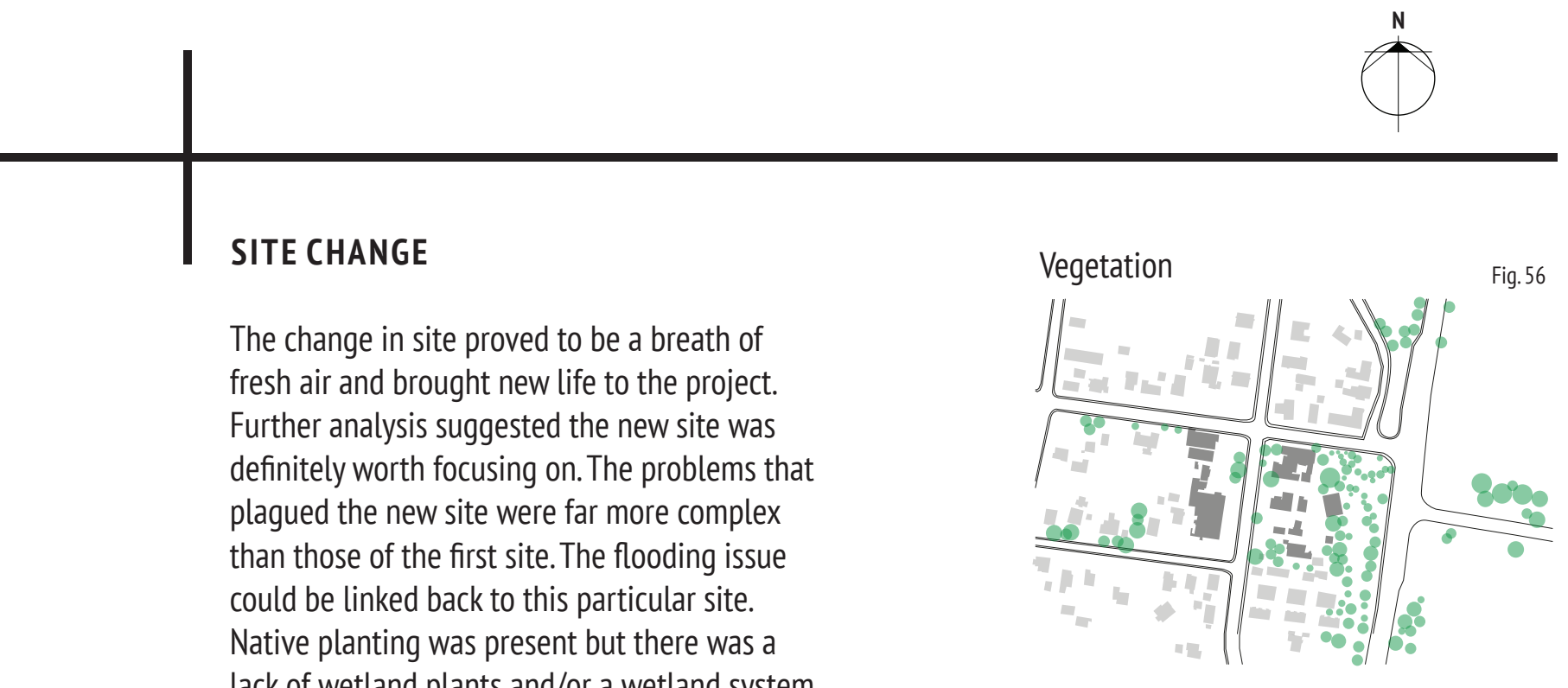

lack of wetland plants and/or a wetland system

due to the streams being piped. The lack of

vegetation didn't allow for water retention,

therefore causing excessive levels of water

that would overwhelm the pipes during heavy

rainfall. This excessive level of water would

cause an overflow in the water catchment.

Another benefit of the site change is that

it is the real gateway to Takapūwāhia and

provides the initial visual connection into the

community meaning that the potential and

beneficial outcomes of redesigning this site are

higher than that of the previously investigated

site. Although the change in location brings

with it many challenges, it has much more

potential to give back to the community

through the mitigation of the current

environmental issues and the representation

of the cultural values of Ngāti Toa at the initial

and more prominent entrance to the home of

Ngāti Toa.
Building Footprint

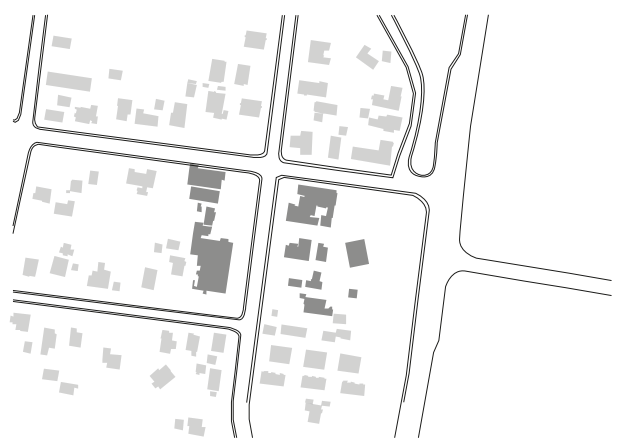

Connections

Fig. 58

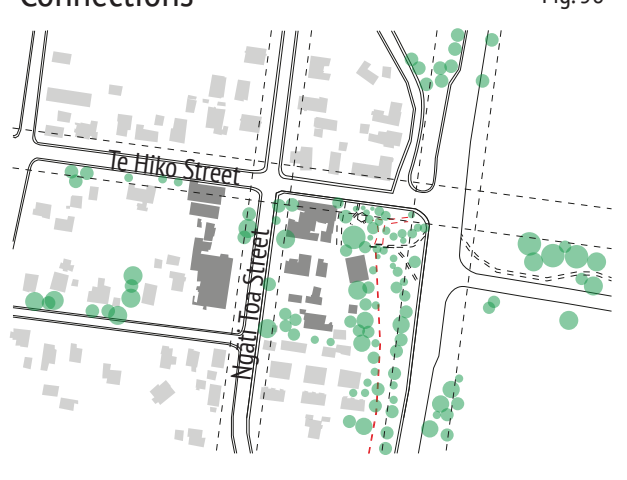

$50 \mathrm{M} \quad 100 \mathrm{M}$

Fig. 56 - 58: Site change and analysis.

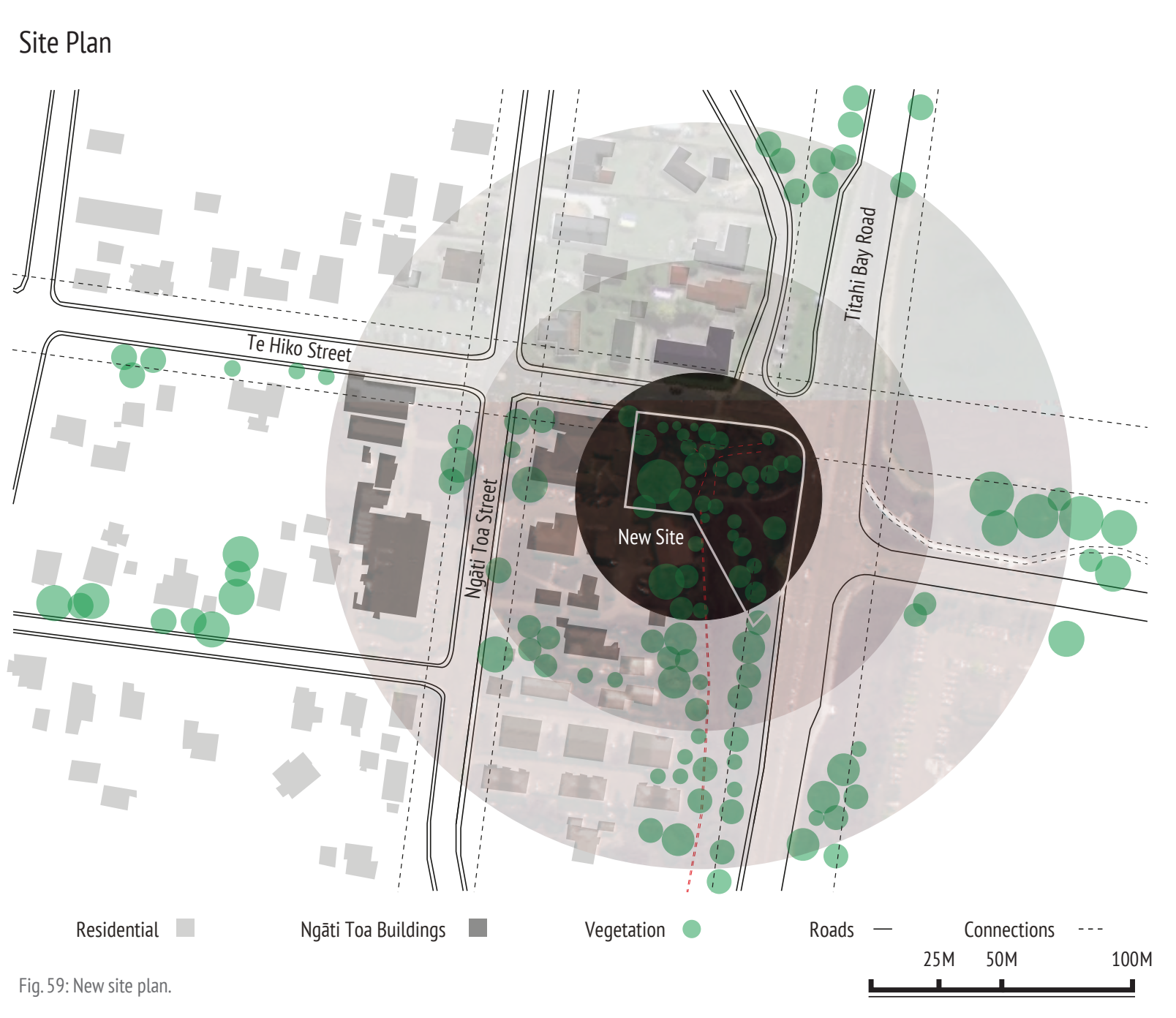




\section{NEW SITE ANALYSIS}

The site, located at the main intersection entering Takapūwāhia, is on the corner of Te Hiko Street and Titahi Bay Road It is at the entranceway to the Takapūwāhia community, but this is not represented visually and there is a lack of any sense of welcoming.Also, it is highly degraded, due to plant location, maintenance and flooding issues, which has caused it to fall into despair. Within the site the Takapūwāhia and Mahinawa Streams are briefly daylighted but are then again piped under the road and empty into the Porirua Harbour. The site is abundant with native New Zealand plants such as pōhutukawa (Metrosideros excelsa) and harakeke, but planting strategies do not help alleviate flooding due to a lack of water retention plants and unsuitable plant placement. Wetland plants not only filtrate the natural water body, but also enable water retention when flooding does occur. The vegetation also does not reference the previous vegetation of the area, which is an important cultural concern.
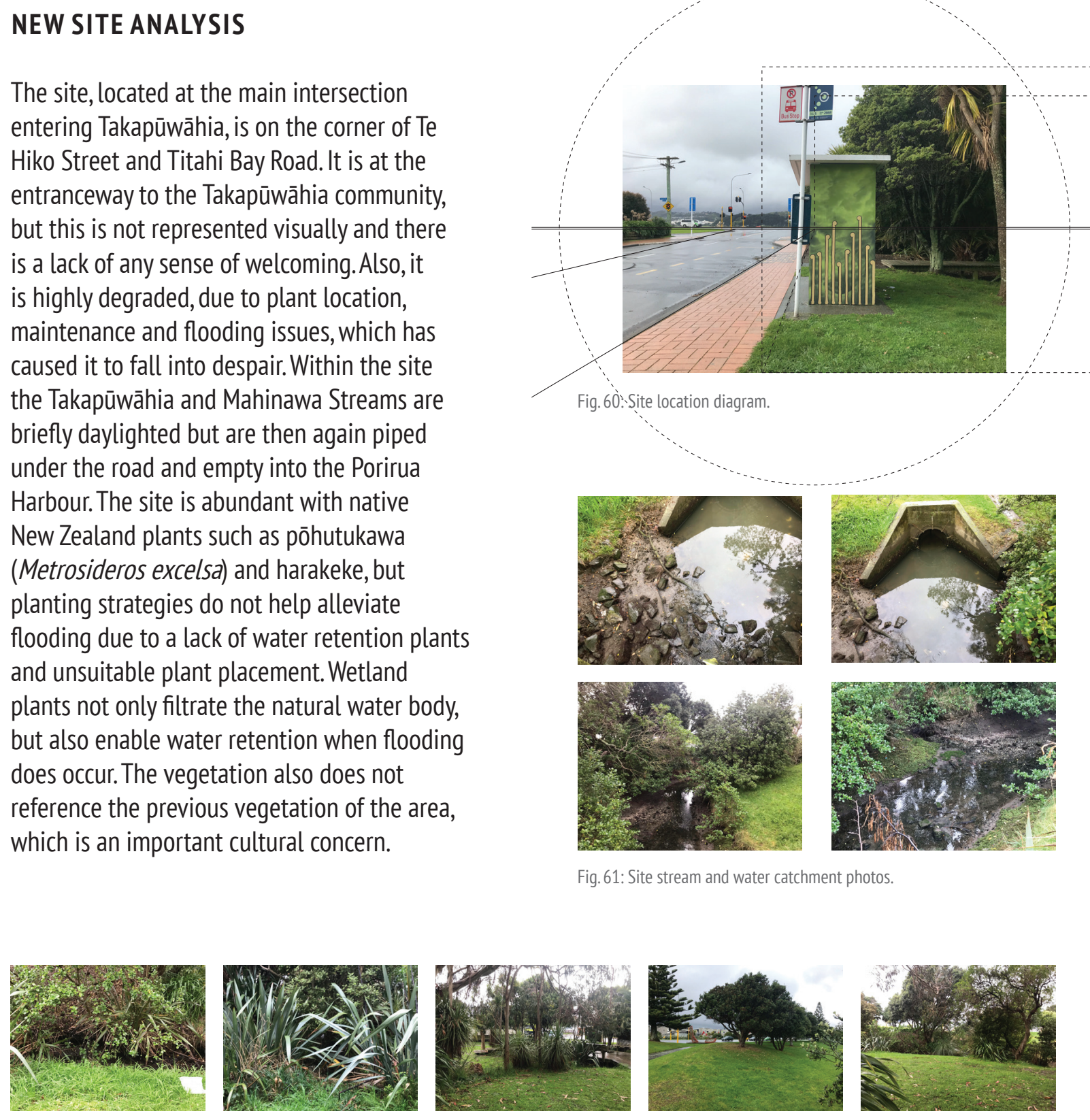

Currently the site has two main entrance points with other secondary openings. The entrance on Titahi Bay Road situates a waka pou (post) to mark the entrance to the suburb. Invitation to the site is lacking due to clutters of trees that have enclosed the space and eliminated a lot of natural lighting. Dense planting means visual connections into and viewshafts through the site are limited. There are a number of exotic plants on site which do not add to the story of the iwi. The walkways within the site consist of a wooden over-bridge with concrete and timber paths and wooden benches for seating. The seating areas are not welcoming and lack a sense of comfort due to the enclosure from canopy trees. There is a distinct lack of features and interest to encourage the user to enter, walk through or sit in the space. The whole area does not function visually, practically or culturally as an entrance to Takapūwāhia.
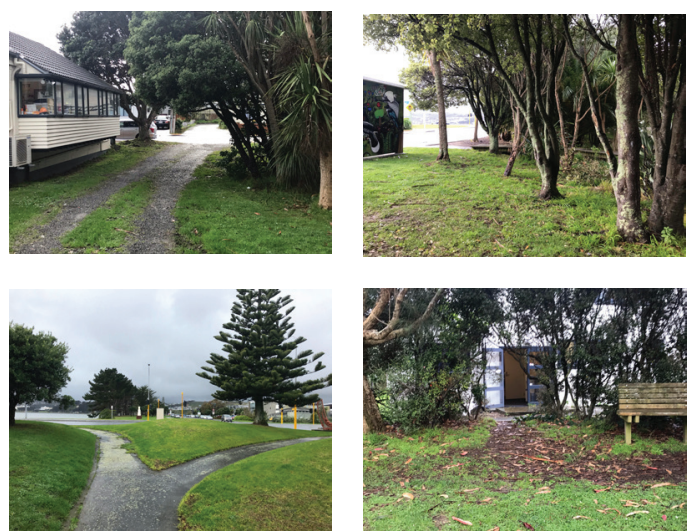

Fig. 63: Site entrances photos.
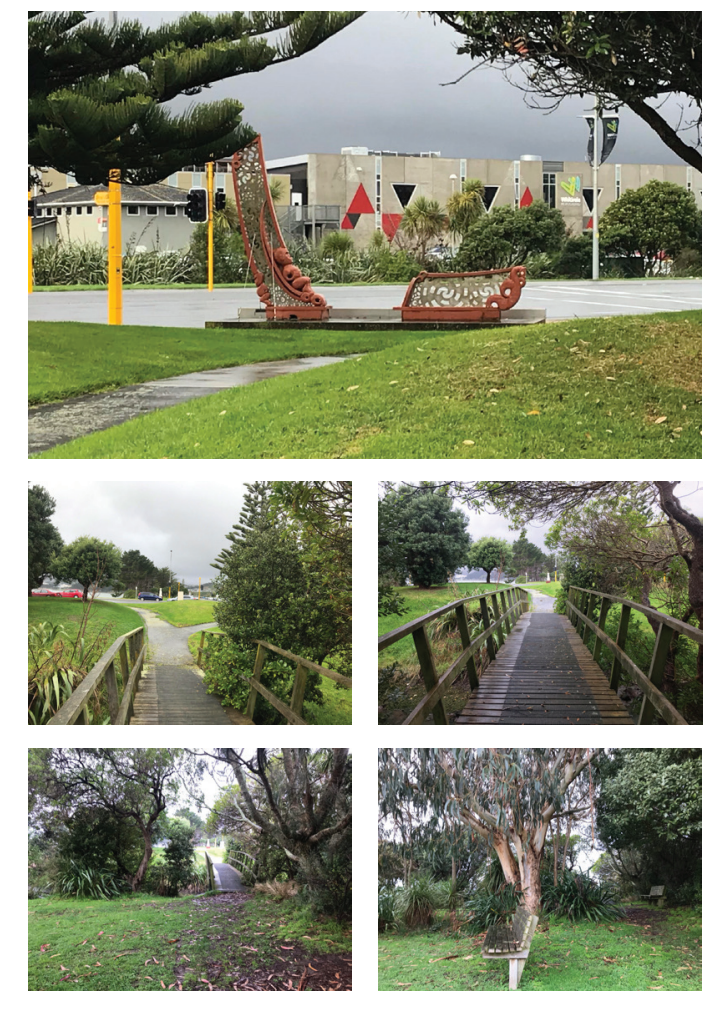

ig.64: Site features photos
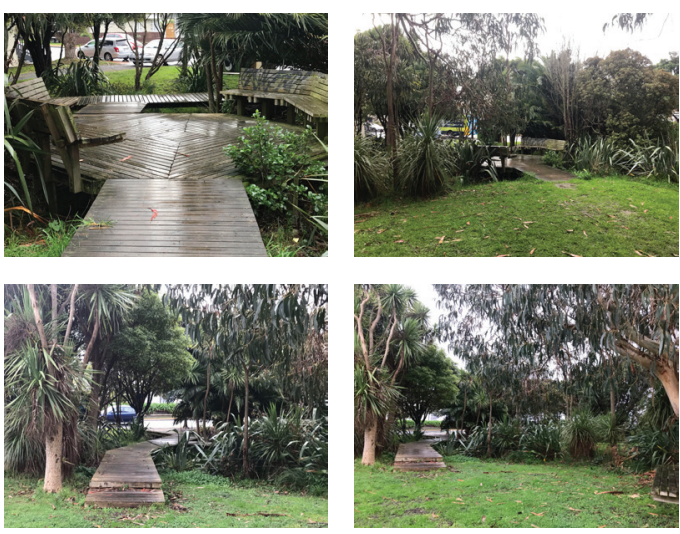


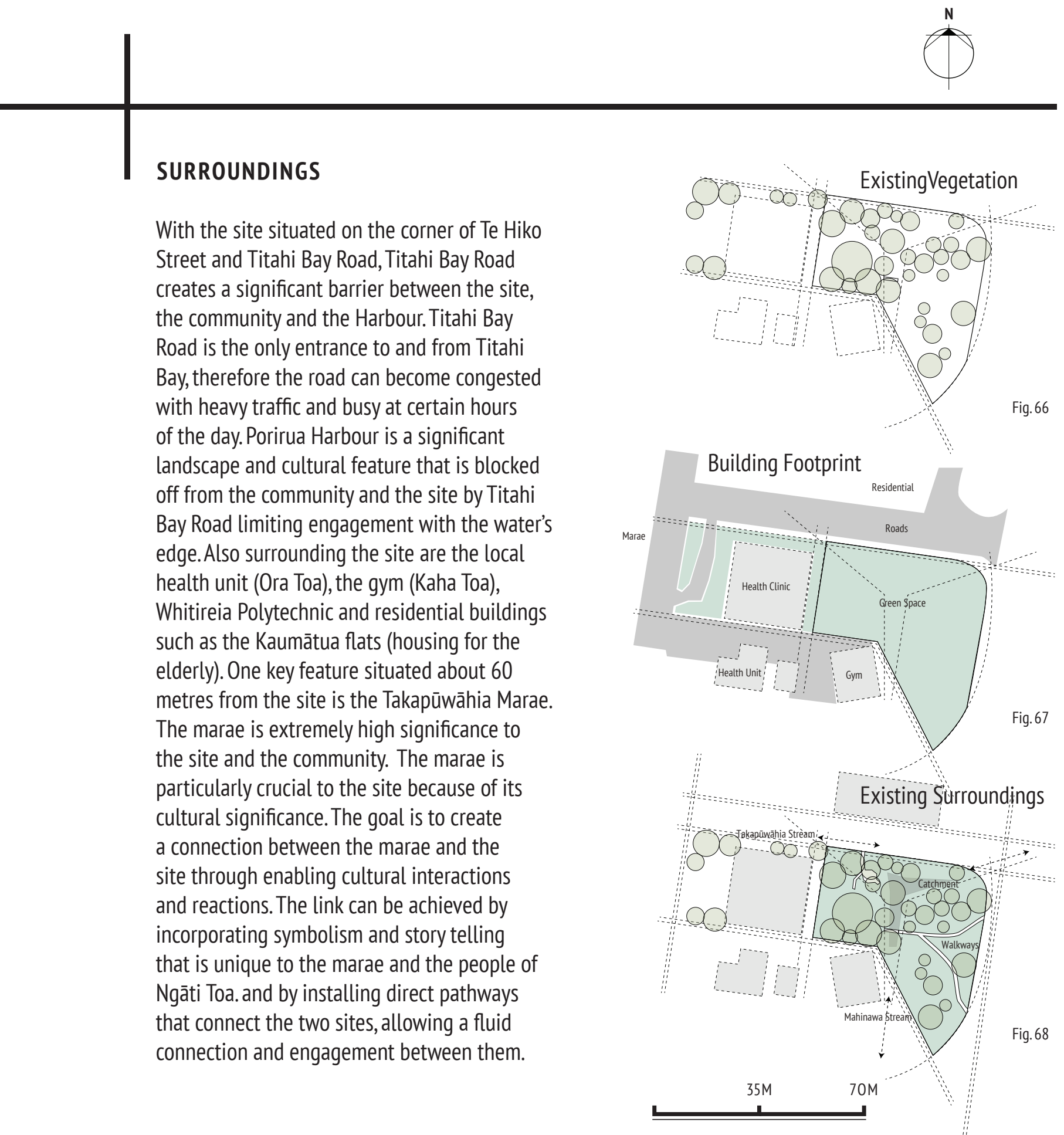

Fig.66 - 68: Site surroundings diagrams
Spatial Relationship

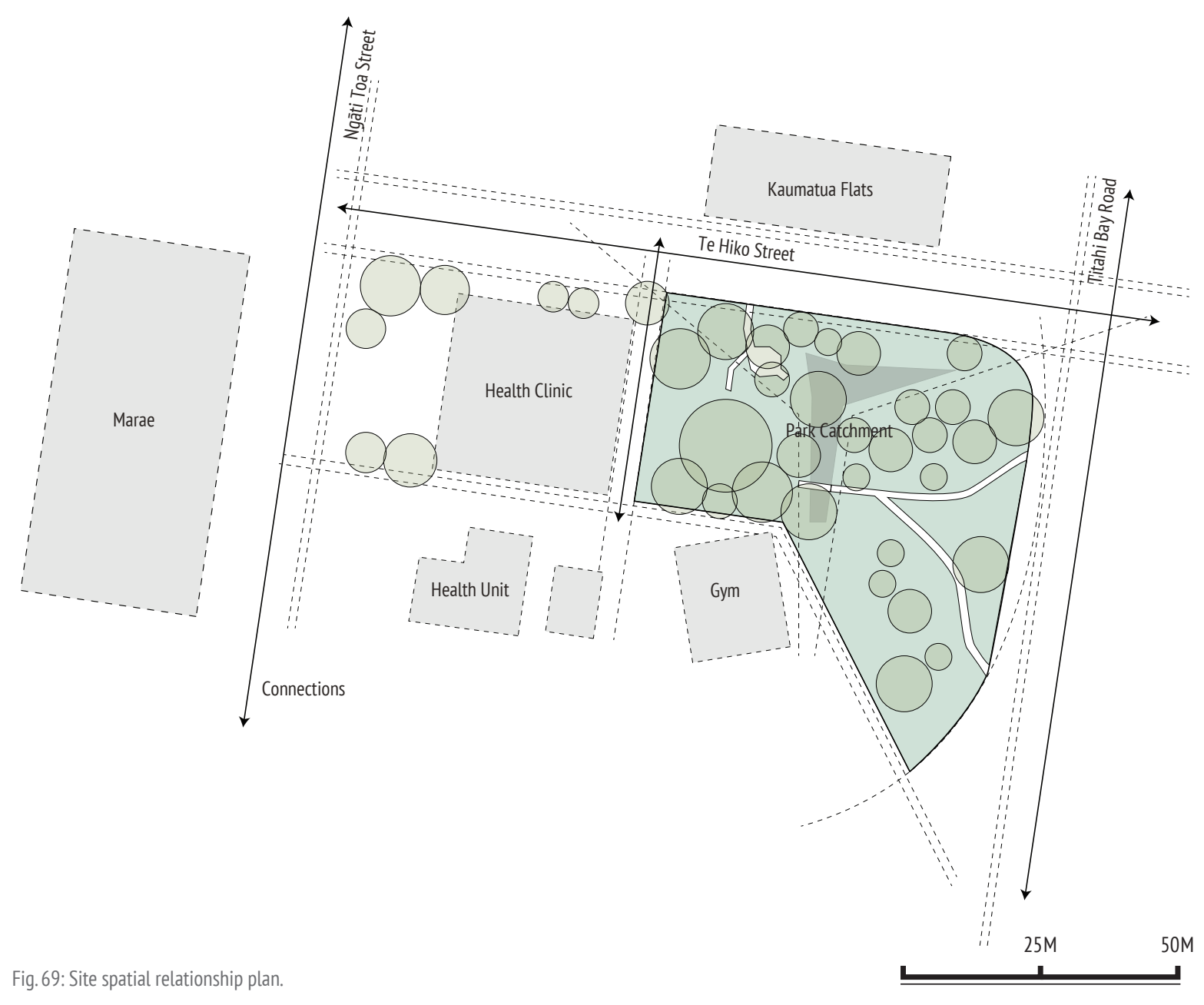


REVISED AIMS AND OBJECTIVES

Mitigate Flooding:

Many community members identified that

flooding is a historical and continuing issue

at some properties in Takapūwāhia. This

poses health risks to the community and

must be addressed. The issue affects the

Ngāti Toa kaumātua flats on Ngāti Toa Street

and has potential to degrade properties and

further degrade water catchments within the community.

Incorporate a Wetland:

Incorporating a wetland system into

the current water catchment will mean

reintroducing wetland plants which will

cleanse the water with a filtration process and

create water retention to avoid overflow.

Integrate and Make Visible Cultural Values:

Integrate significant cultural aspects such

as Ngāti Toa symbolism, stories and values

into all aspects of design so as to visually

make present the culture, cultural values and

practices of the Ngāti Toa iwi.
Implement Green Street Features:

Applying green street features to the street

such as vegetation, surface changes and road

layout will enhance a pedestrian friendliness

and allow a water retention system to help

mitigate flooding issues.

\section{Increase Connections:}

The design will create connections between

the people, the land, the culture and their

environment.

Functional Vegetation:

Vegetation will be used in planting

beds, gardens, wetlands and street trees.

Incorporating vegetation into the design will

focus on what function plants can have in a

design. These will include ecosystem functions

such as water retention and water filtration,

as well as cultural functions, such as culturally

significant plants suitable for their specified

locations.

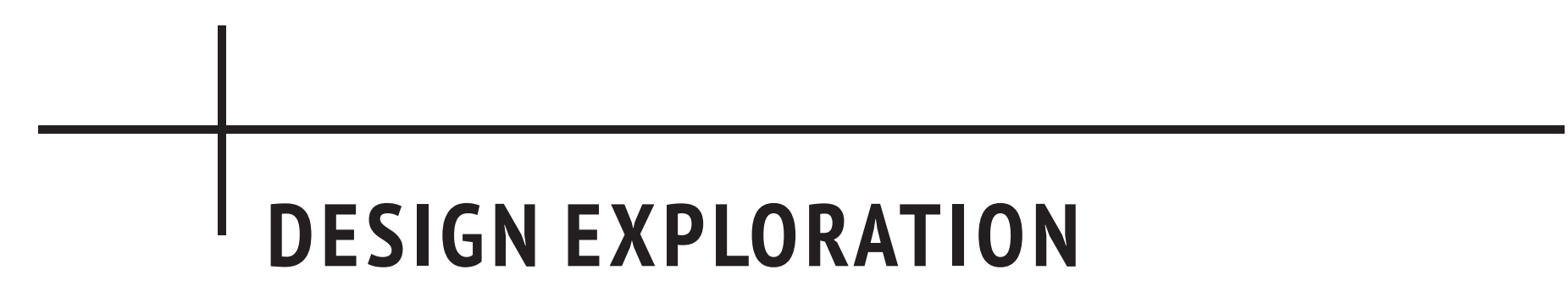

DESIGN EXPLORATION 


\section{Design Ideas}

The first Participatory Design session allowed the participants to understand the issues in their community and to explore design ideas that would respond to these issues. The key elements that needed addressing along with understanding the developing cultural shift were how to: express Ngāti Toa and their values; mitigate flooding issues; reconnect the people to the land; allow community

engagement with the environment; and unite

a disconnected community.

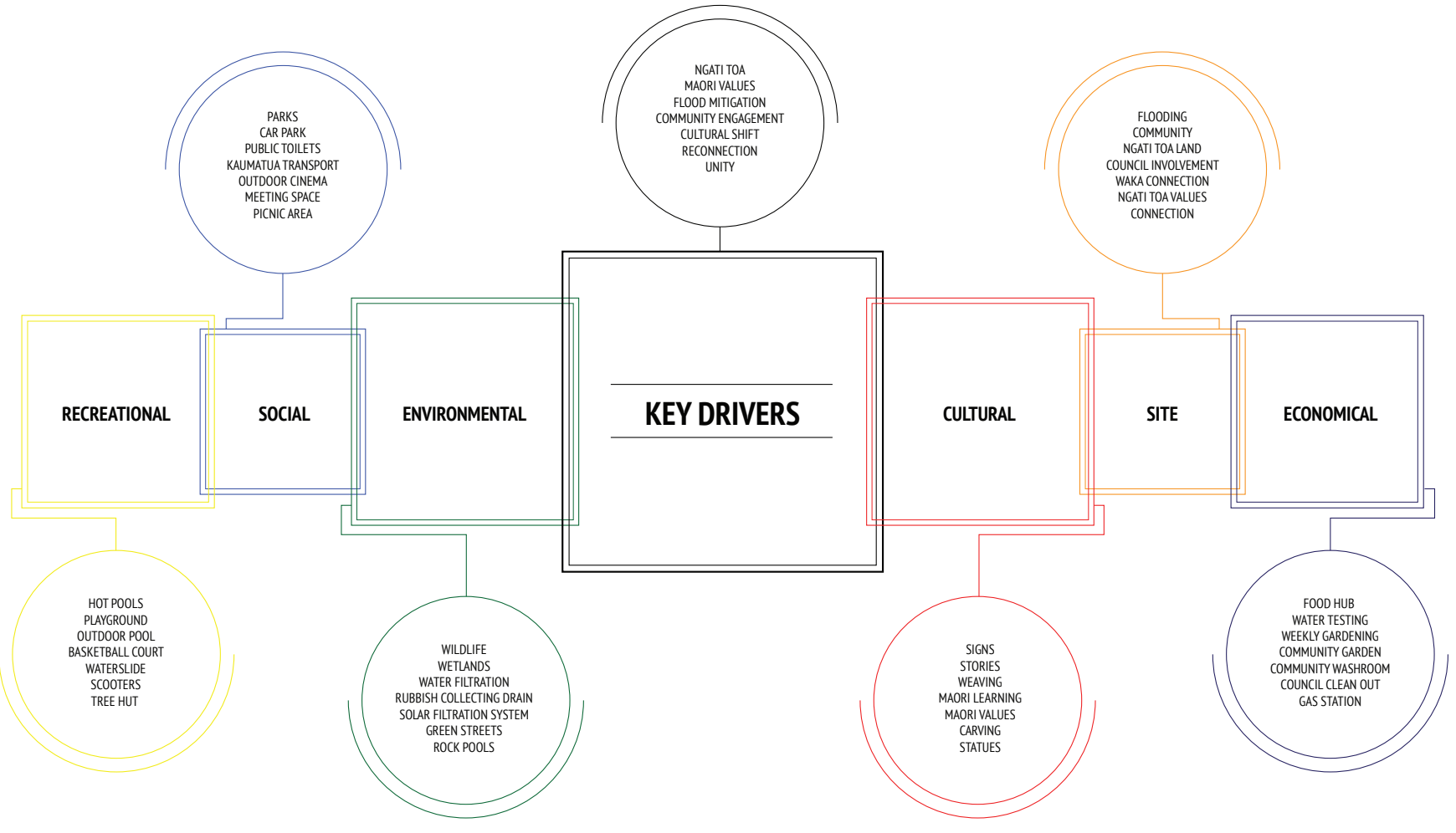

Fig. 70: Participatory Design ideas diagram.
These were then related to six categories

environmental, cultural, social, recreational, site and economical. The goal was to create design

ideas that would cater to these six categories

and respond to the issues.

The participants brainstorming session provided inspiring ideas that addressed the issues. These were collated and grouped:
By combining the participants' ideas and exploring them, the researcher developed potential solutions to the existing issues in the community:

- Applying cultural values in design through Māori symbolism.

- Creating pedestrian-friendly streets by

incorporating green street design.

- Creating a wetland park to address

environmental issues and cultural disconnect.
Integrating components such as pedestrianfriendly green streets, meeting places, cultura symbolism, Māori artwork, wetlands, natural water systems, water retention/filtration and connections/pathways into the Takapūwāhia community, will best express the $\mathrm{Ngāti} \mathrm{Toa}$ iwi values and create a story unique to their people.

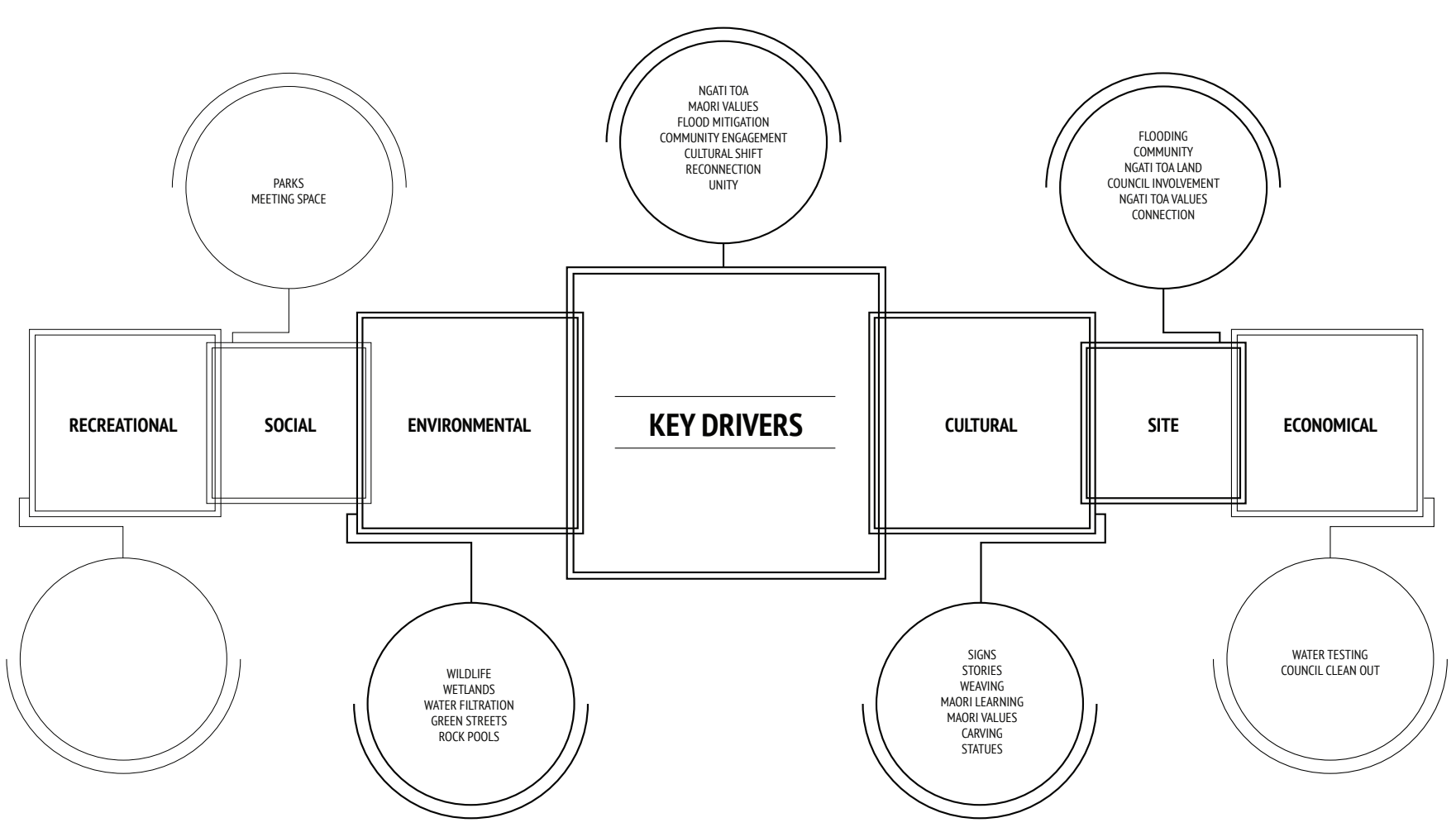

Fig.71: Researcher ideas diagram. 
Incorporating Māori symbolism into the desig is an effective way of representing the local iw and the cultural identity and values significant to them. Mãori symbolism is portrayed best through patterns. These patterns represent certain aspects or features that are of

importance to Māori. For example, a Koru is a spiral pattern that represents new life, growth, strength and peace. Māori symbols have a reason, a story and a meaning that expresses their values and represents their culture.

For this project, symbolism particularly significant to Ngāti Toa, will be represented in various design features to tell a story that is unique to Ngāti Toa.

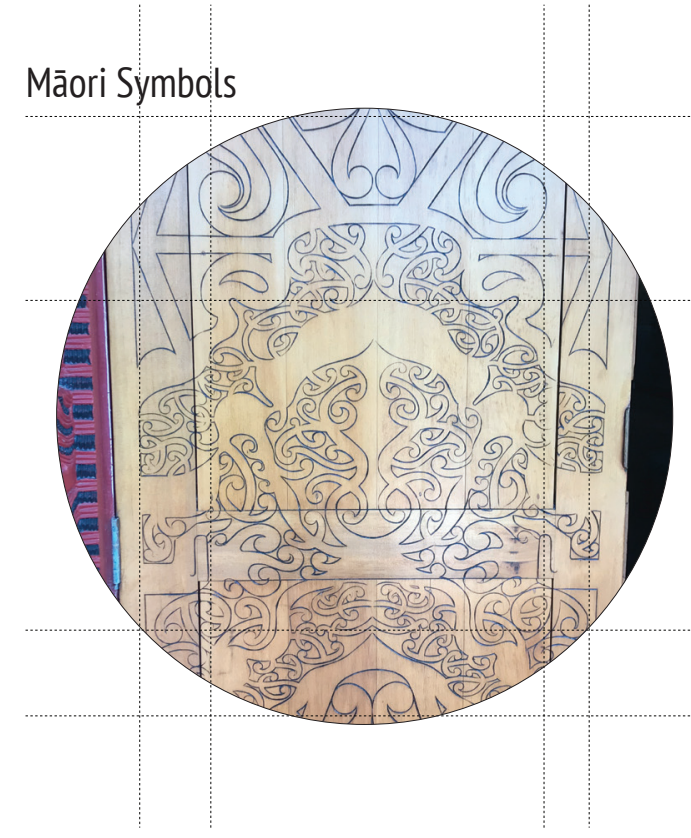

Fig.72: Mäori design symbols.
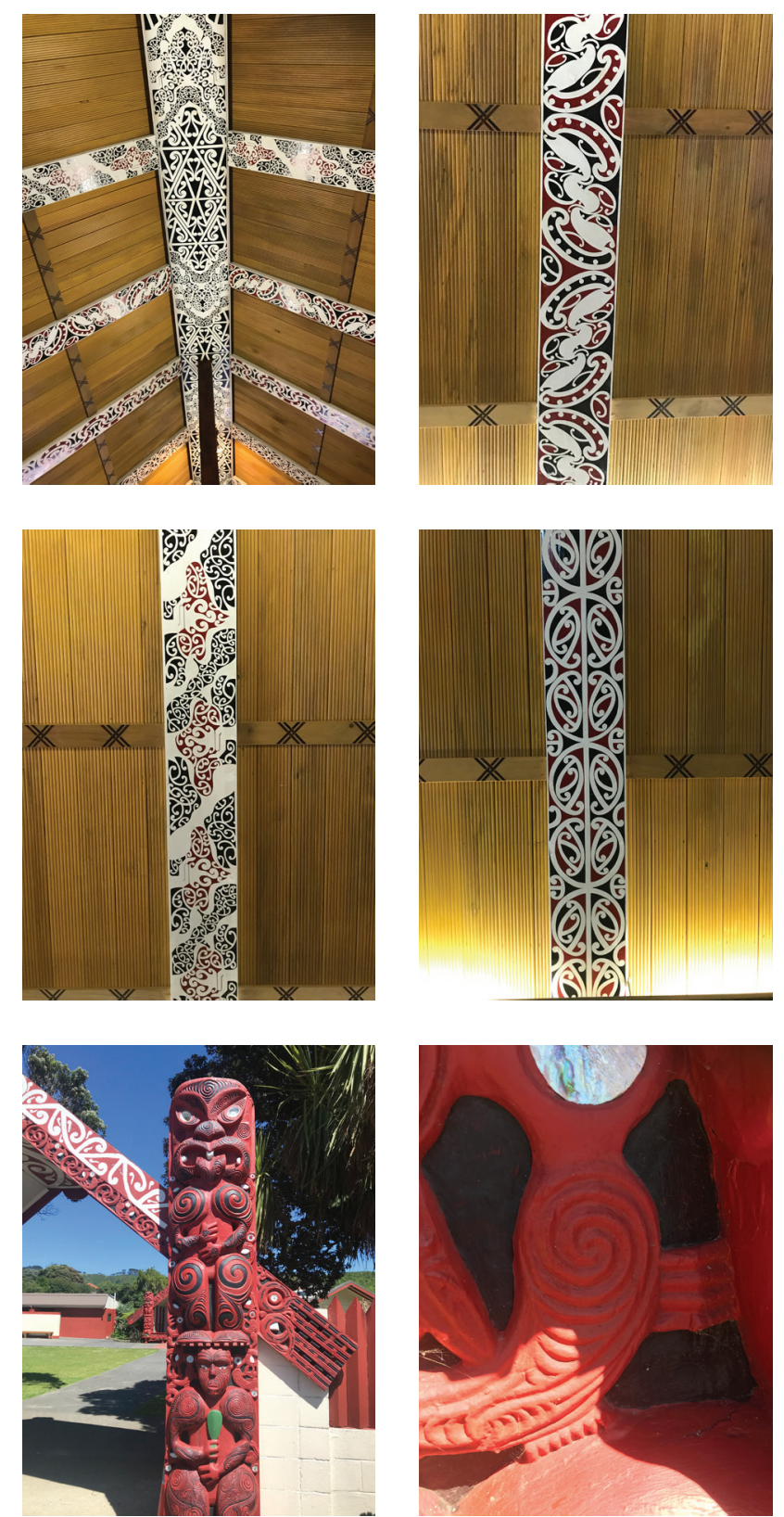

Fig.73: Takapūiuăhia Măori symbols.
THE MĀORI SYMBOL S REPRESENTED IN VARIOUS DESIGN FEATURES

The Koru (loop)

is a spiral shape that takes the form and appearance of a new unfurling silver fern

frond. This shape is an integral symbol in Māor culture, where it symbolises new life, growth, strength and peace (New Zealand Signs).

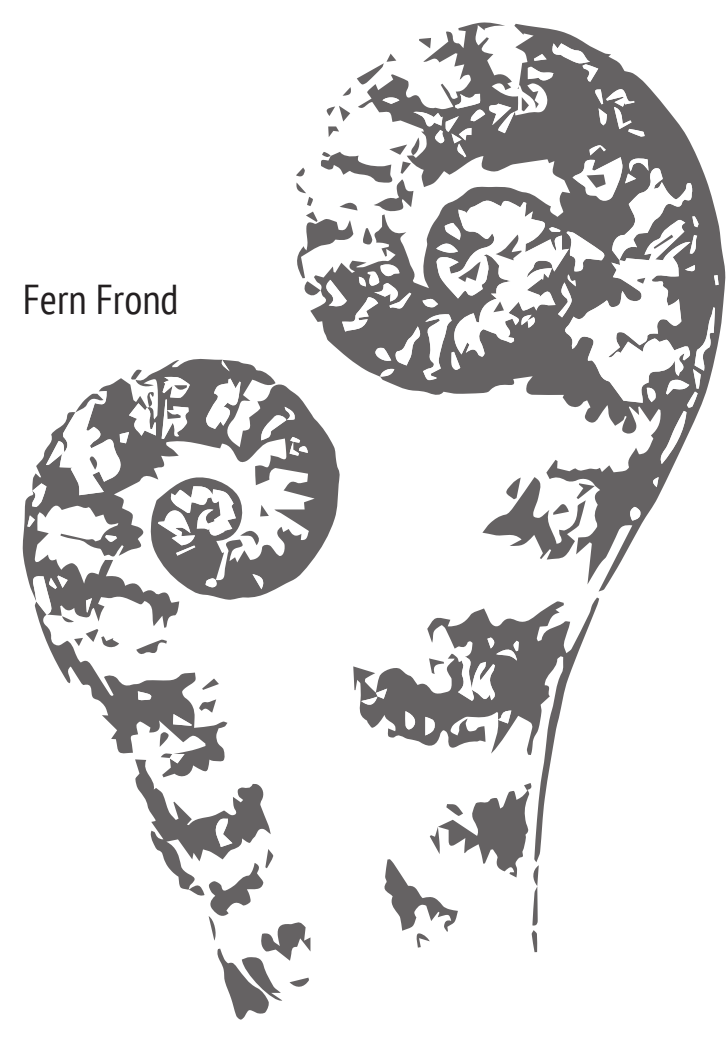

Fig. 74: Fern drawing.

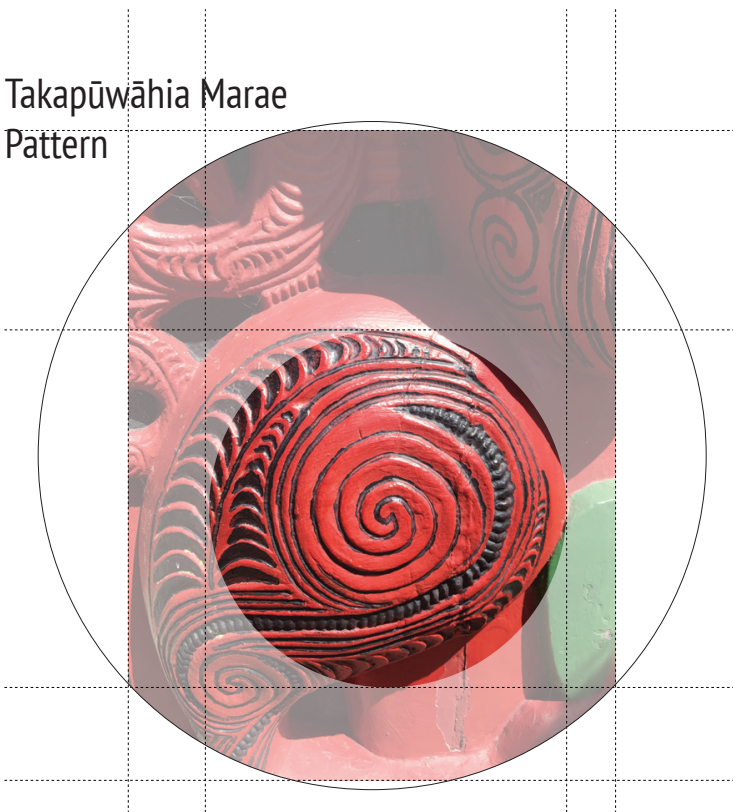

Fig. 75: Marzee pattern diagram.

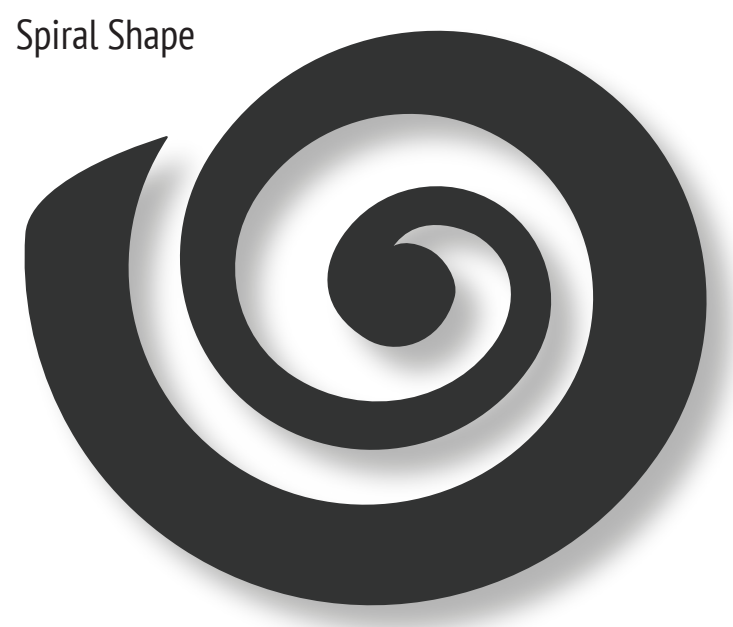

Fig.76: Spiral drawing. 
Te Wheke (octopus)

perceived as being a holistic model of health

and well-being. The octopus defines family

health in Mãori folklore. The head of the

octopus represents whānau (family) and iwi

(tribe); the eyes of the octopus represent

wairoa (well-being), and a specific dimension

of health is represented in each of the eight

tentacles (Pere).

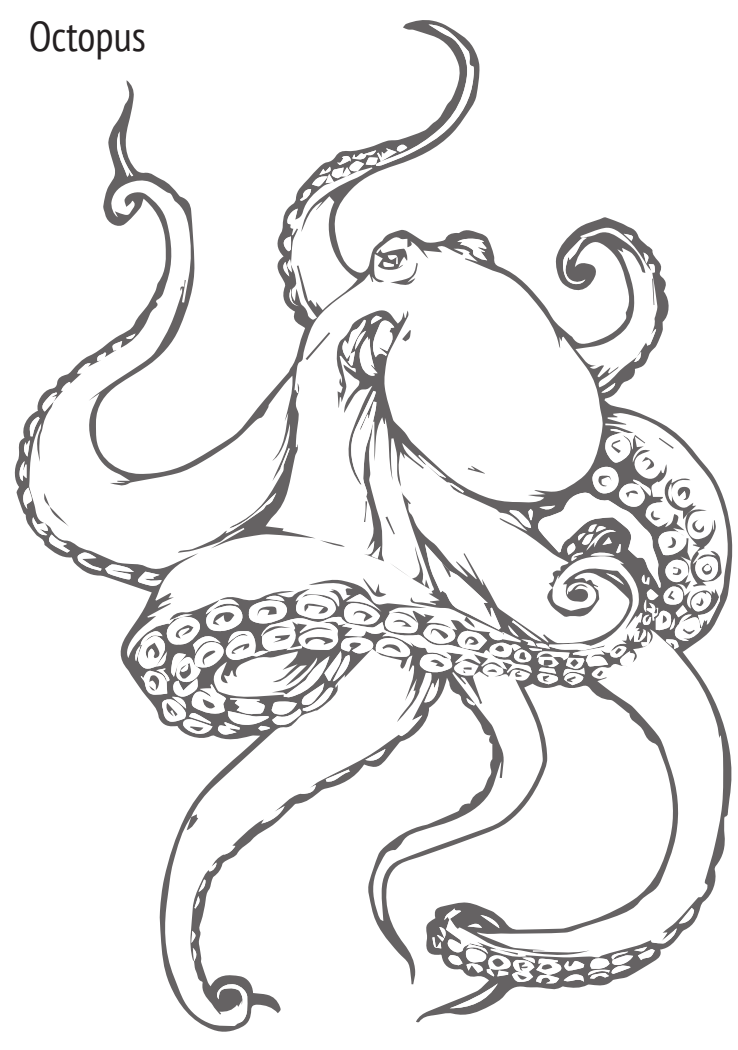

Fig. 77: Octopus drawing.
Takapūwāhia Marae

Pattern

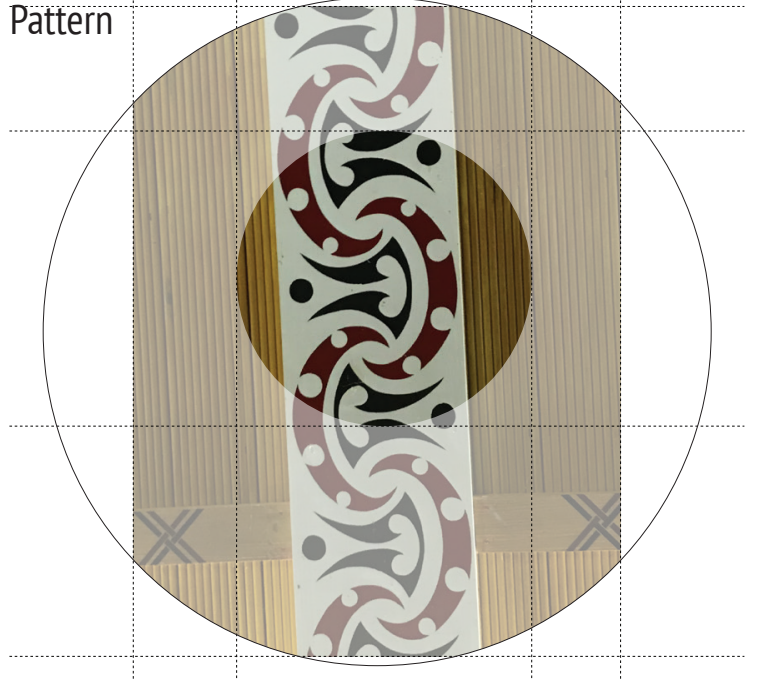

Fig. 78: Marae pattern diagram.

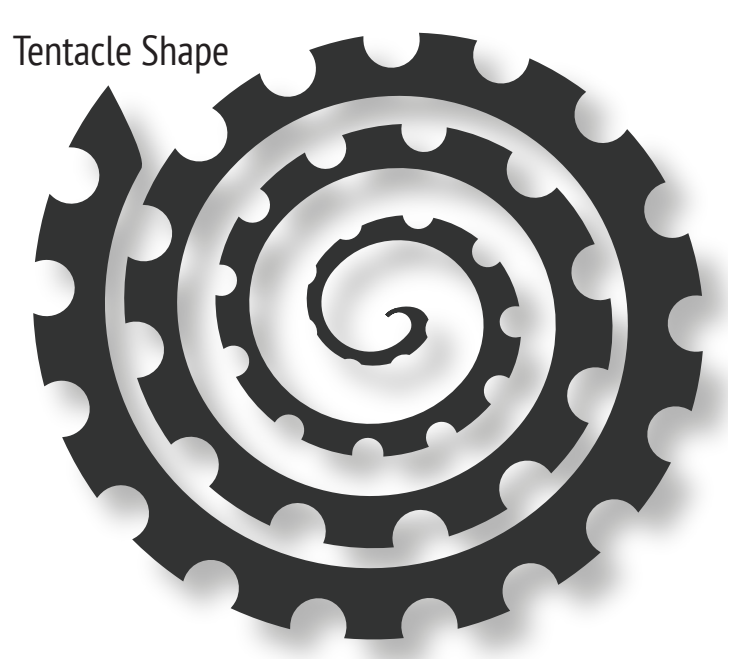

Fig.79: Tentacle pattern drawing.
The Mangopare (hammerhead shark)

represents strength, leadership, agility, tenacity, unrelenting determination, courage and wealth The dynamic motion of a Mangopare echoes the constant interconnected flow of water sea and sky. It is also a symbol of an everlasting bond of friendship that time and space cannot affect. This symbol relates to the connection between the marae and the site. It creates an everlasting bond and portrays all the great qualities of strength and unrelenting determination of the Ngāti Toa people (New Zealand Signs).

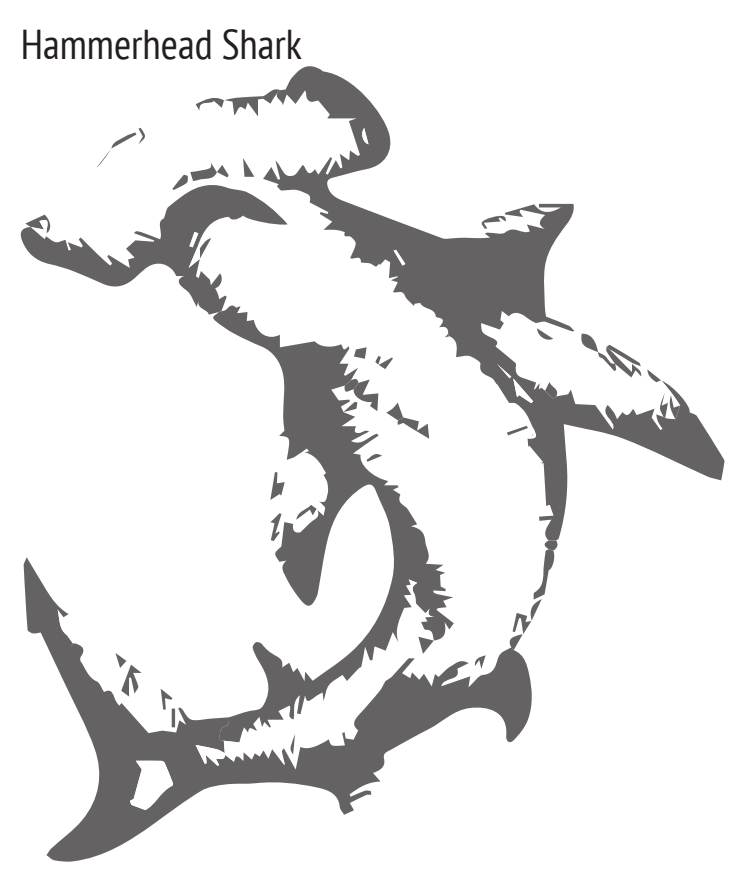

Fig. 80: Hammerhead Shark drawing.

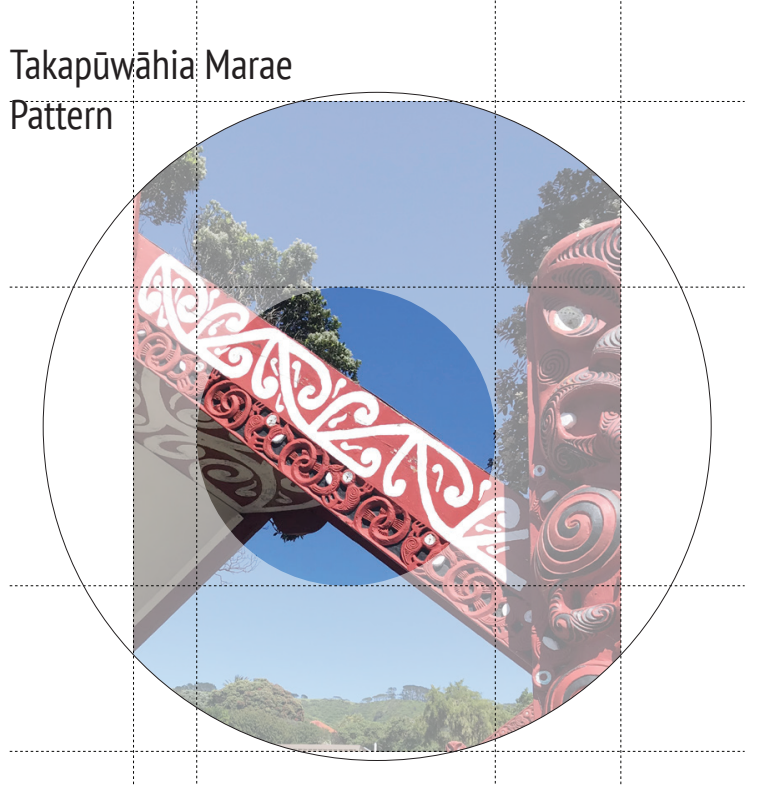

Fig. 81: Marąe pattern diagram.

Hammerhead Shape

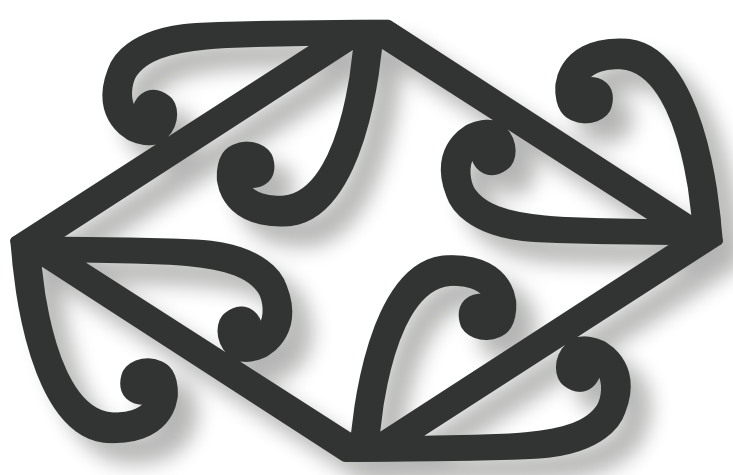

Fig.82: Hammerhead pattern drawing. 
The Tukutuku (traditional Māori art latticework panels) symbols are to be represented in various design features.

Nga Kete Matauranga: This pattern pays homage to the three baskets of knowledge which Tane received when he climbed to the highest heaven. They are:

- Kete Tuauri: basket of peace, goodness and love.

- Kete Tuatea: basket of prayers, rituals and incantations.

- Kete Aronui: basket of war, stonework, woodwork, earthwork and agriculture.

These three baskets of knowledge have an important place in Māori mythology. They represent the outpouring of divine wisdom to humanity. This was to enable man to fulfil his destiny on earth. They embraced all the aspects of demands and responses essential in man's striving to reach his full potential, physically, intellectually and spiritually. It is understood that these three baskets are commemorated in the three figures of carving in wood, stone and bone and in the three karanga of welcoming. They are also commemorated in the three words of welcome 'Haeremai, haeremai,

haeremai', the treble emphasis in the greeting 'Tena Koutou, tena koutou, tena koutou katoa' and in the words of farewell to the dead, 'Haere, haere, haere'.

This pattern is built up by a simple repetitive unit crossing each other diagonally and creating a basket weave effect with prominence given to the main feature, the three bars are representing the three baskets. As with true tukutuku design, the pattern run off all the edges and continues into infinity (Katene).
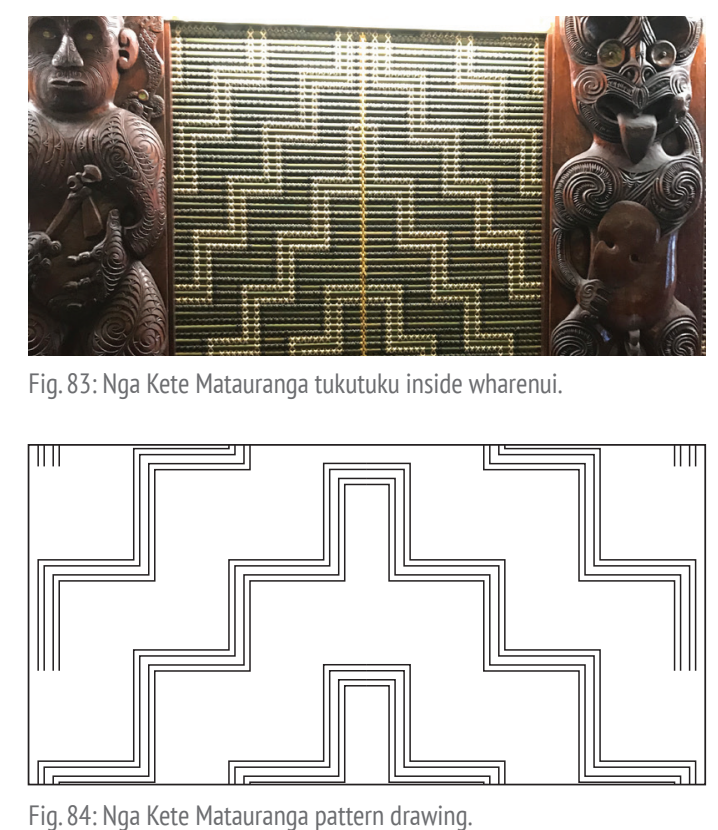

Whakatupuranga Rua Mano: The design is a simple statement of the classic poutama pattern. Within the context of Whakatupuranga Rua Mano (connecting generations), this pattern symbolises the achievement of reaching full potential in all aspects of one's personality and abilities. These are the intellectual, physical, emotional, emotional an spiritual capacities that each is endowed with

The golden rod which pierces the centre of the panel represents the standards, expectations and goals of achievement. The steps representing each 'capacity' converge at the central attainment points along the gold

rod. The pattern is never-ending and carries on into infinity suggesting the unlimited range of these capacities and the need to bring them to fruition at some point, no matter how distant. The pattern is perfectly balanced. Its structured form rises confidently with measured tread from a broad support base. Whakatupurang Rua Mano is an action programme for the twenty-first century rather than the vision of possibilities. It is an invitation to excel, to climb and to achieve (Katene).
These symbols represent Ngāti Toa as an iwi and Ngăti Toa as a people. These symbols define the cultural values that have sustained Ngāti Toa for many generations. They portray the stories and the significance to the journeys, strength, health and benefits of the iwi.

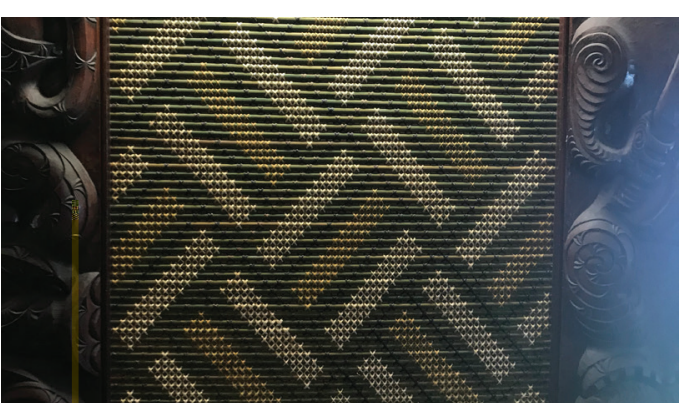

19.85: Whakatupuranga Rua Mano tukutuku inside wharenui.

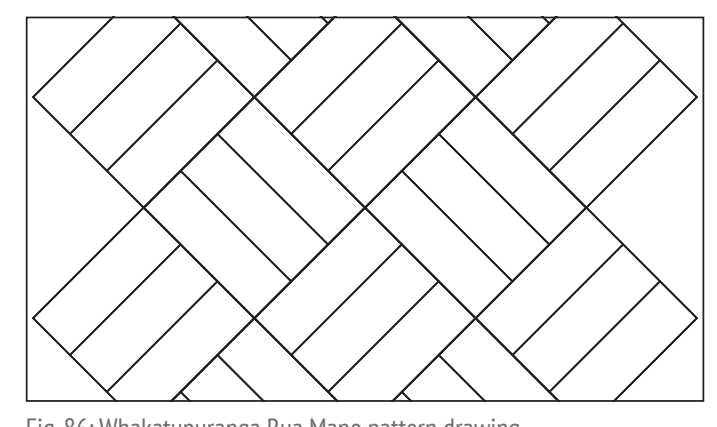

196: Whakatupuranga Rua Mano pattern drawing. 
DESIGN ITERATION - INVESTIGATING POTENTIAL

Sketch Testings

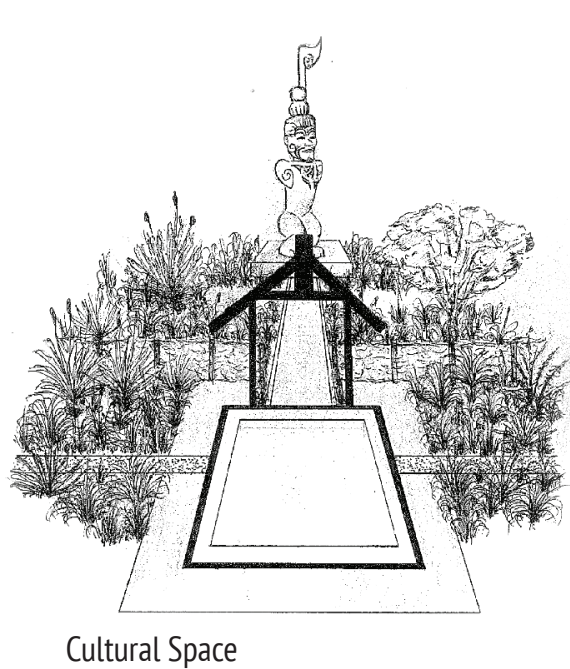

Fig. 87: Design iterations

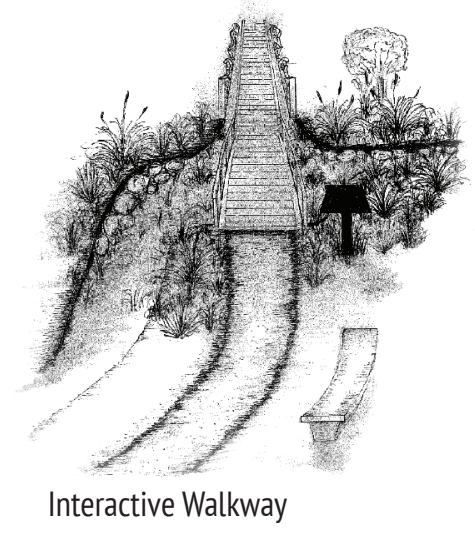

Interactive Walkway

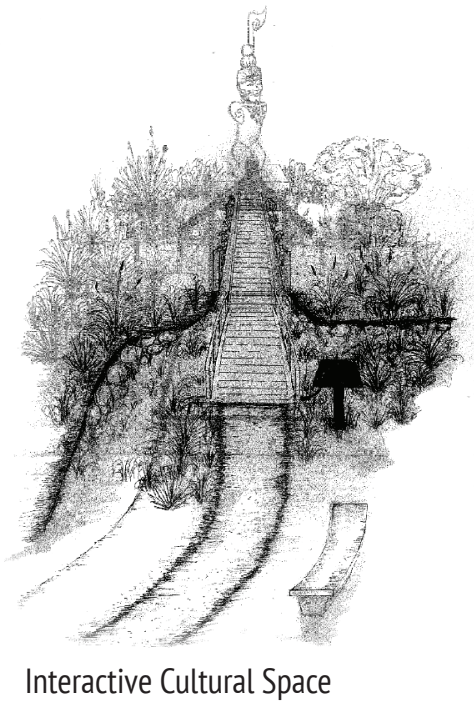

Interactive Cultural Space
Sketch Testings

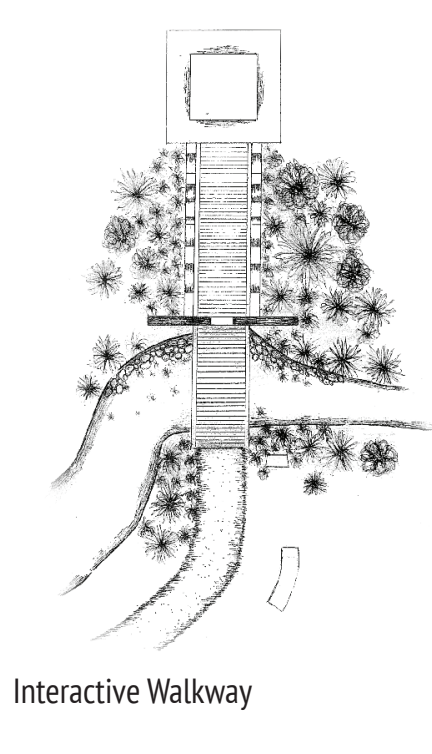

Fig. 88: Design iterations part two.

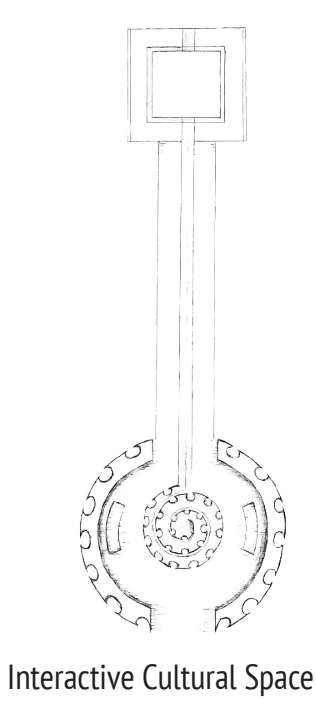

Interactive Cultural Space

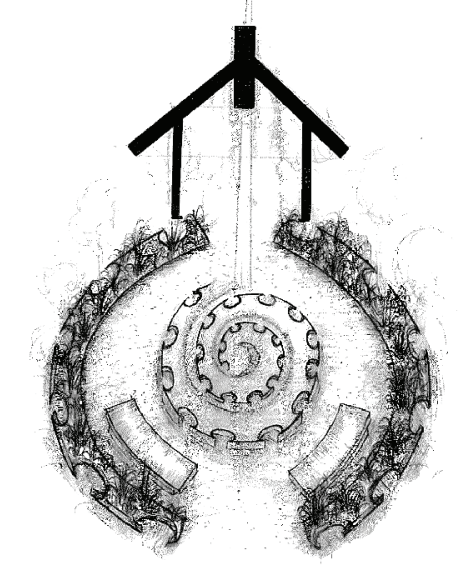

Cultural Symbolism Design Features 
Section Testings

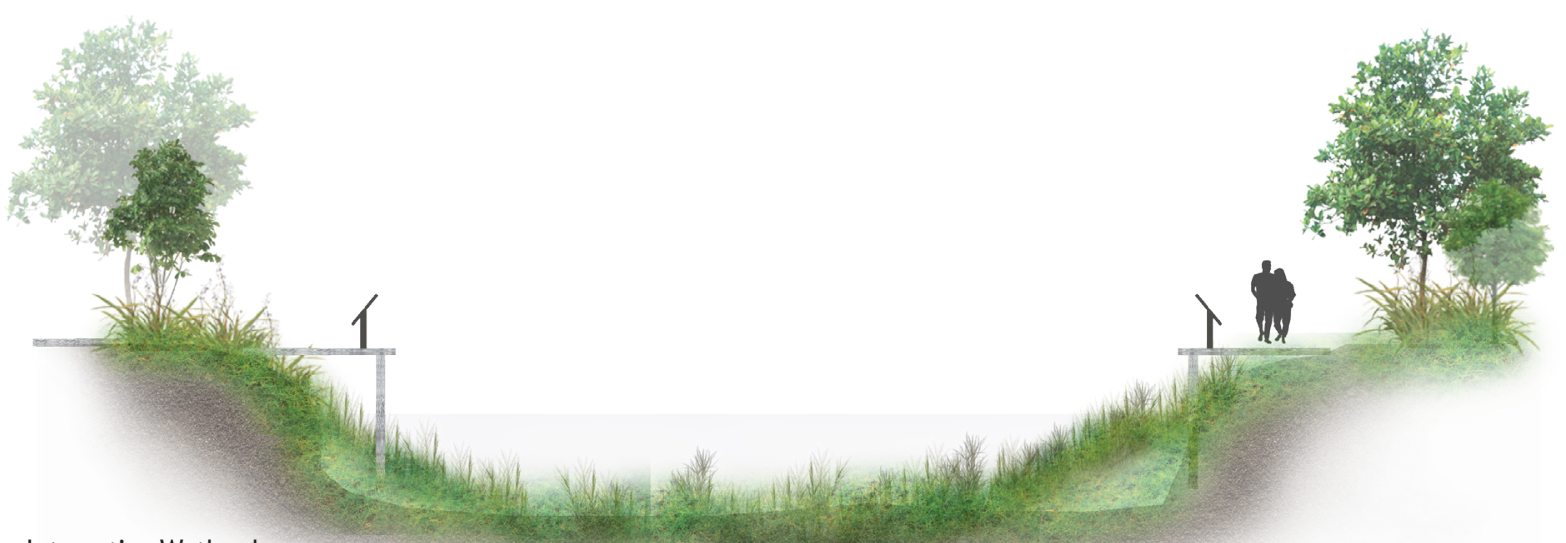

Interactive Wetland

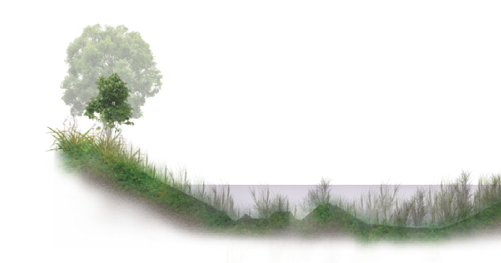

Wetland Design

Fig. 89: Section testings.
Section Testings
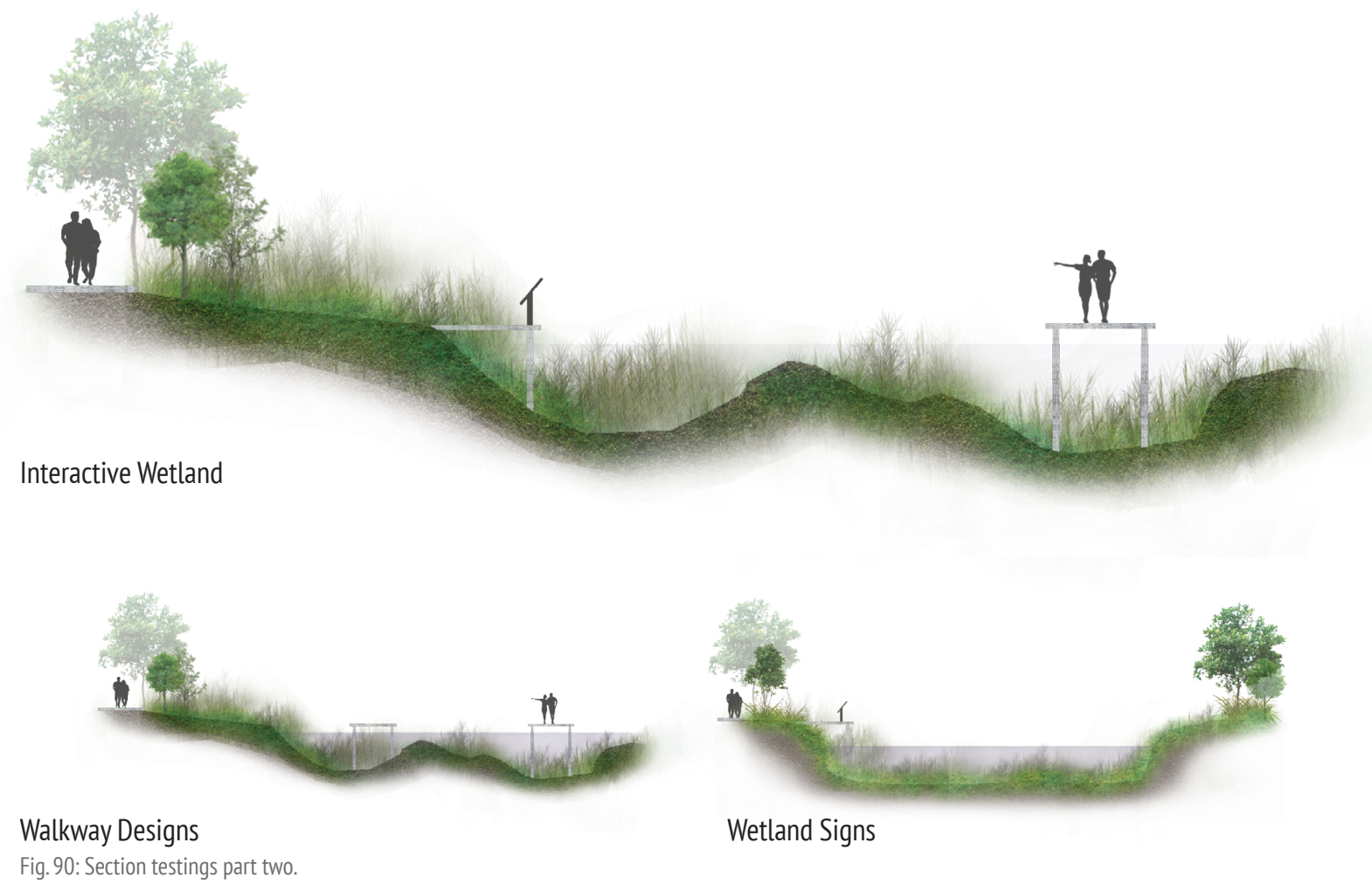
Axonometric Testings

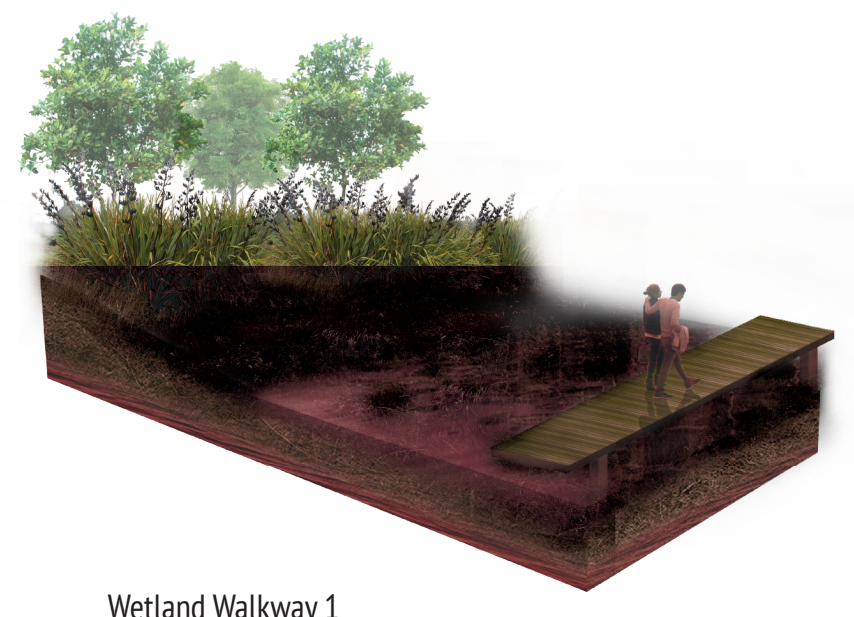

Fig. 90: Axonometric drawings

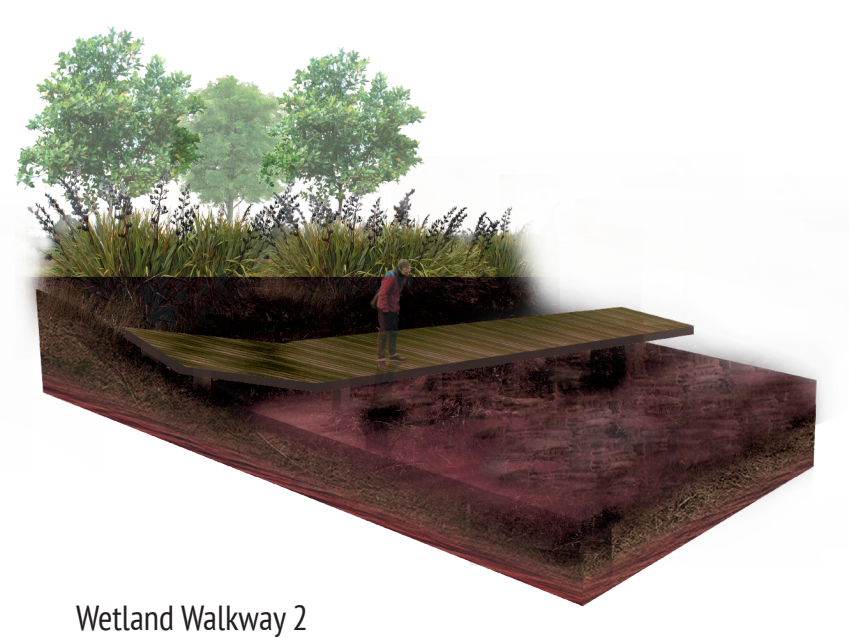

Wetland Walkway 2
Axonometric Testings

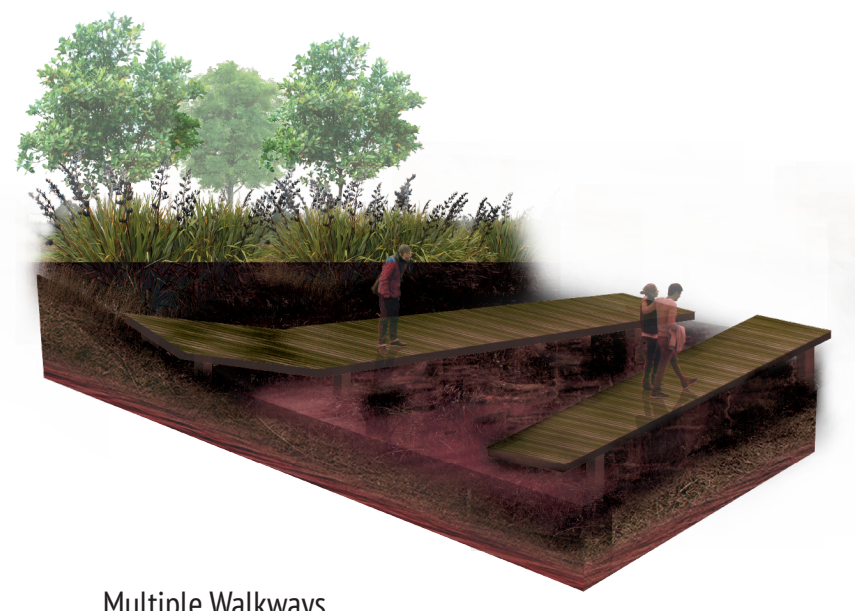

Multiple Walkways

Fig. 91:Axonometric drawings part two.

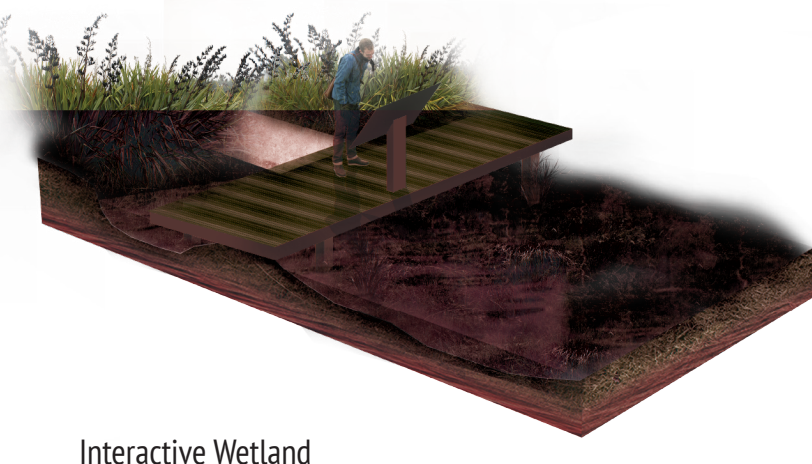

Interactive Wetland 


\section{Green Street Design}

Introducing Green Street Design to floodaffected areas within Takapūwāhia will provide a natural system approach to reduce ongoing issues affecting the area. This approach will help control stormwater flow, improve water quality, slow traffic, enhance pedestrian safety, reduce carbon footprints and beautify the neighbourhood.

The Green Street Design along Te Hiko and Ngăti Toa streets will feature permeable paving, sidewalk planters, vegetated curb extensions, and street trees.

Ngāti Toa Street
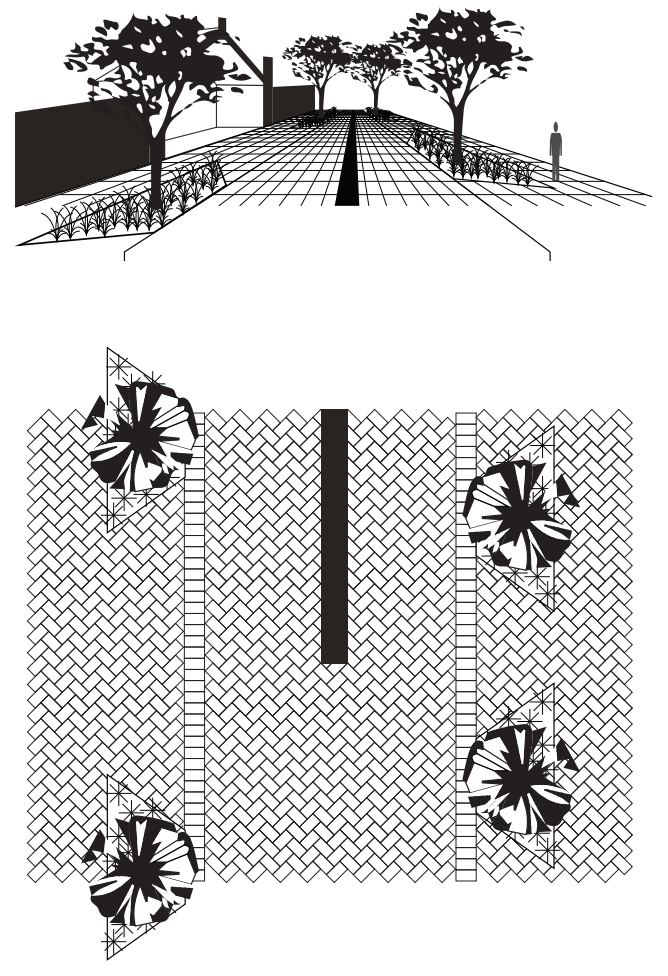

Te Hiko Street
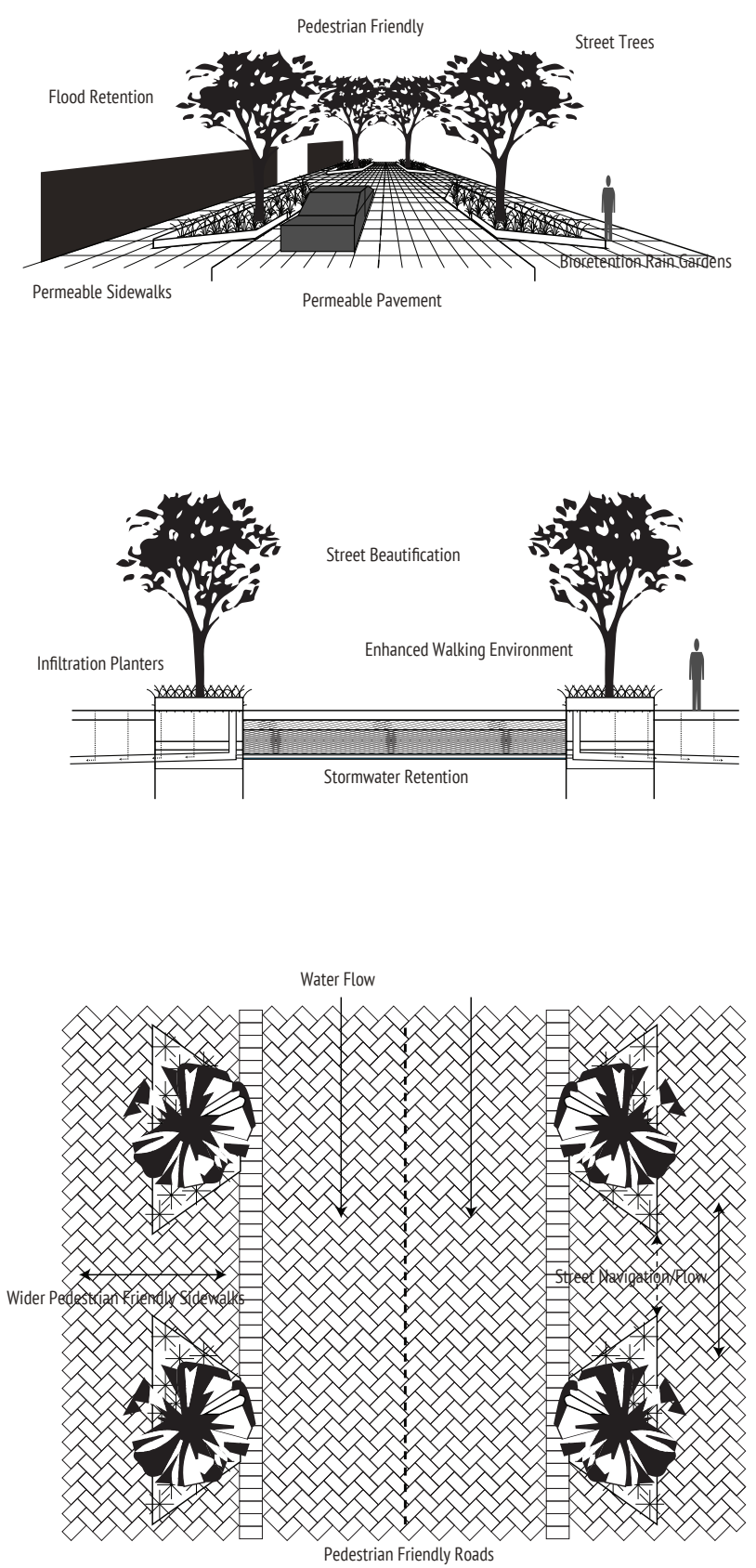

PERMEABLE PAVING

The installation of permeable paving along Te Hiko and Ngāti Toa Streets, adjacent to the marae, will not only provide a pedestrianfriendly surface but also control traffic

speeds and form a flood retention barrier. The permeable surface will slow the process of water overflow on the street through its durability, load-bearing qualities and underlying reservoir that temporarily stores water before infiltration.

The permeable paving will be complemented by the integration of water retention plants such as Oioi (Apodasmia similis) and Toetoe (Austroderia), among others. These plants will be located along the sidewalks in rain gardens to help slow surface water overflow. The rain gardens will be located in areas of the street particularly prone to flooding. The gardens will help filter runoff naturally and will be easily maintained requiring less maintenance than that of regular turf grass.

The use of permeable paving is also an effective way of slowing traffic due to its textured surface creating a bumpy feeling for vehicles. This also will improve the hierarchy of pedestrians in the street, as the vehicles become less dominant and the surface relates to that of the sidewalk.
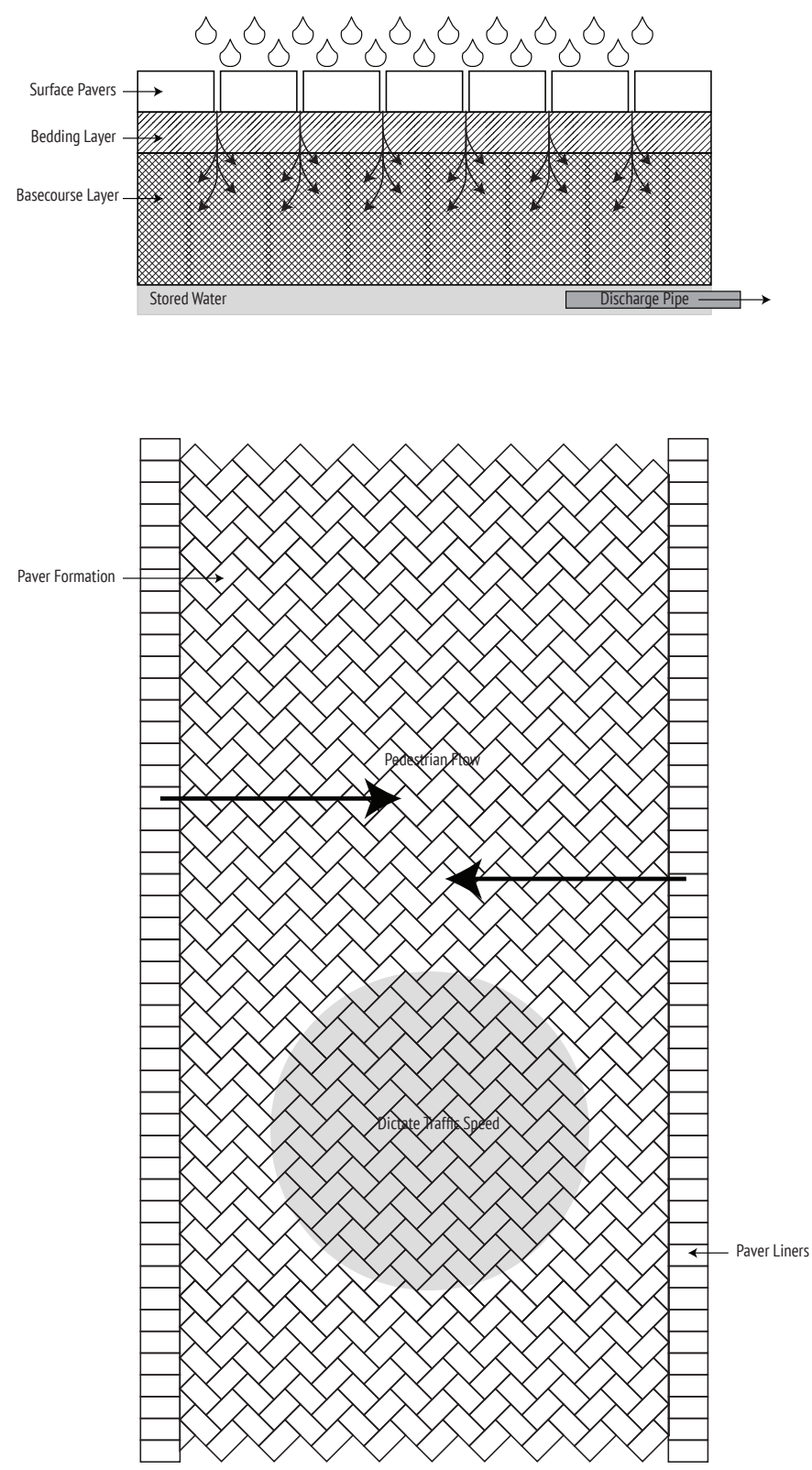

Fig. 93: Permeable paving diagrams.

Fiq.92: Green Street diagrams. 


\section{SIDEWALK PLANTERS}

Sidewalk planters are extended, narrow landscaped areas with vertical walls and flat bases, typically open to the underlying soil. They allow for more storage volume than a swale in less space which is particularly ideal for suburban streets. Water flows into the planter, absorbs into the plants and topsoil, fills to a predetermined level, and then, if necessary, overflows into a storm sewer system. Sidewalk planters can accommodate street trees (Nevue Ngan Associates).

Sidewalk planters also have benefits such as: Environmental: Sidewalk planters incorporate trees and other plantings that help reduce the carbon footprint. Native species planted in the planter provide food, water and shelter to birds and insects.

Stormwater management: Planters collect and store stormwater, reducing the amount that enters storm sewers and basements.

Aesthetics: median plantings and architectural elements contribute to the identity and beautification of the neighbourhood. This allows for an enhanced visual experience for pedestrians, drivers and passengers (Nevue Ngan Associates).
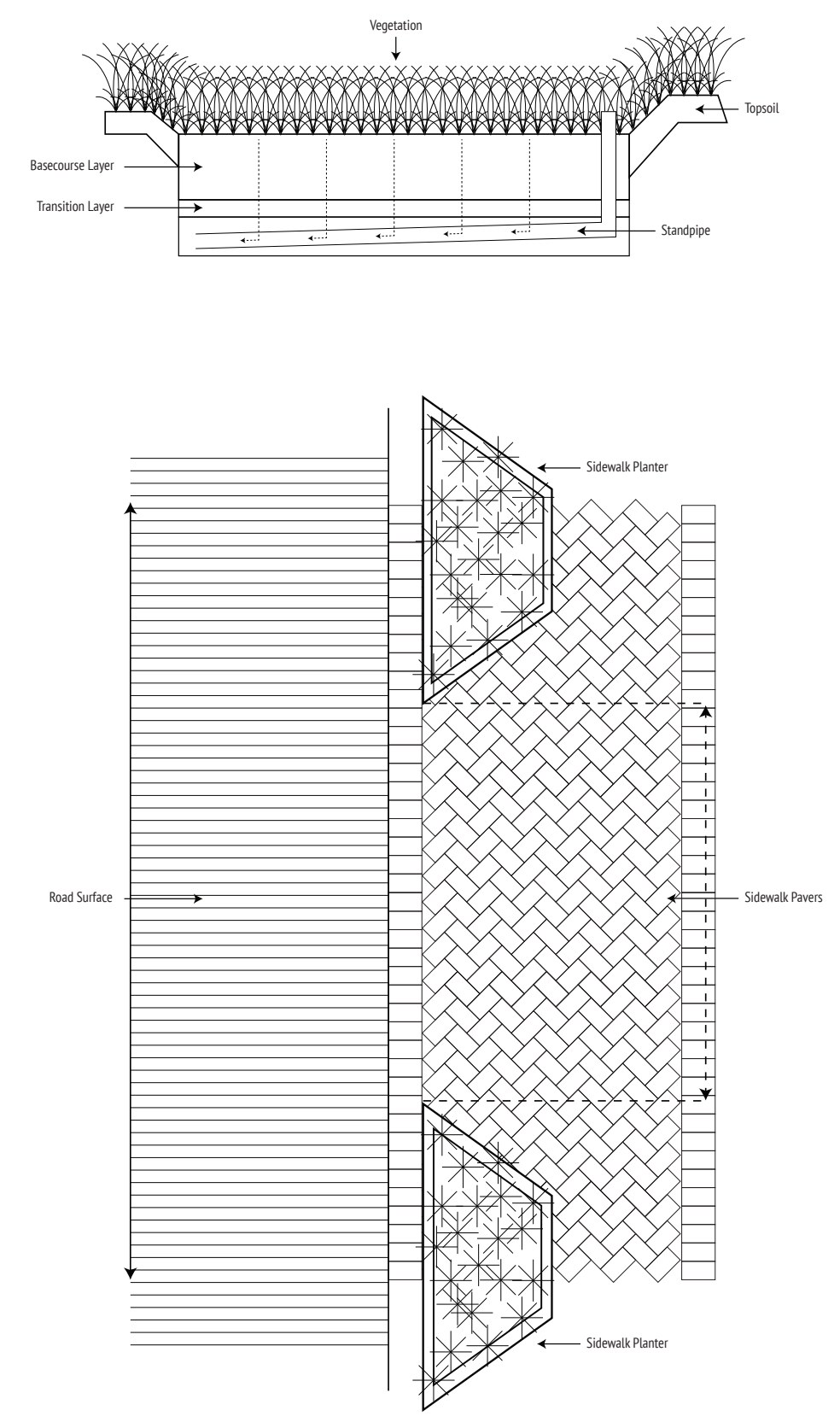

Fig. 94: Sidewalk planter diagrams.
VEGETATED CURB EXTENSIONS

Vegetated curb extensions on residential streets, are typically located near the corners of the road. These rain gardens can provide the pedestrian with a more comfortable feeling when walking alongside or crossing the street. The landscaped area can be designed to be similar to a rain garden or vegetated swale and enables infiltration and evapotranspiration for stormwater management. They can be planted with groundcover, grasses, shrubs or trees, depending on the site conditions, costs, and design context. Vegetated curb extensions can be used at a roadway intersection, midblock, or along the length or block of the roadway. They can be combined with pedestrian crosswalks to increase safety along a road (Nevue Ngan Associates).

Additionally, vegetated curb extensions provide traffic calming opportunities along with stormwater management opportunities. Vegetated curb extensions can be added to existing roadways with minimal disturbance and are very cost-effective as retrofit opportunities. They can be used in a variety of land uses and are an excellent technique to incorporate along steeply sloping roadways. They are also effective pre-treatment practices for runoff entering other Green Street

practices, such as infiltration trenches or sidewalk planters. vegertion

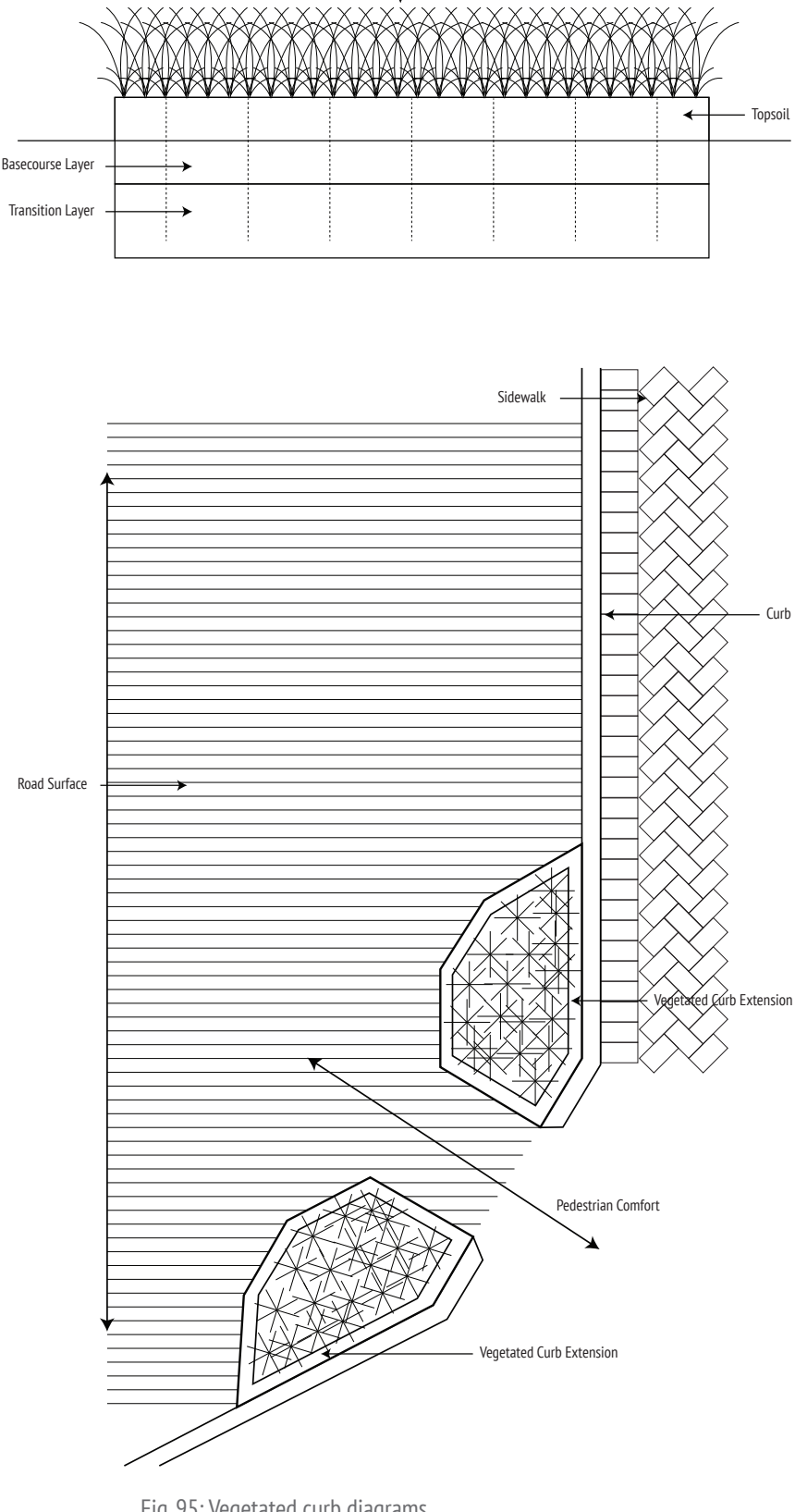




\section{Te Hiko Street Wetland Park}

\section{STREET TREES}

Incorporating street trees can help create a safer walking environment. This can be by forming and framing visual walls that provide distinct edges to sidewalks. This allows

motorists to better distinguish between the auto-oriented environment and one shared with people (Heather).

Street trees also increase security and create a more pleasant walking environment. This friendly environment increases walking, talking, pride, care of place, association and therefore actual ownership and surveillance of the area. They enable connection to nature and the human senses (Heather)

Street trees absorb the first $30 \%$ of most precipitation through their leaf system, allowing evaporation back into the

atmosphere. This moisture never hits the ground. Another percentage (up to $30 \%$ ) of precipitation is absorbed back into the ground taken in and held onto by the root structure. This is then absorbed and transpired back to the air. Some of this water also naturally percolates into the groundwater and aquifer (Heather).
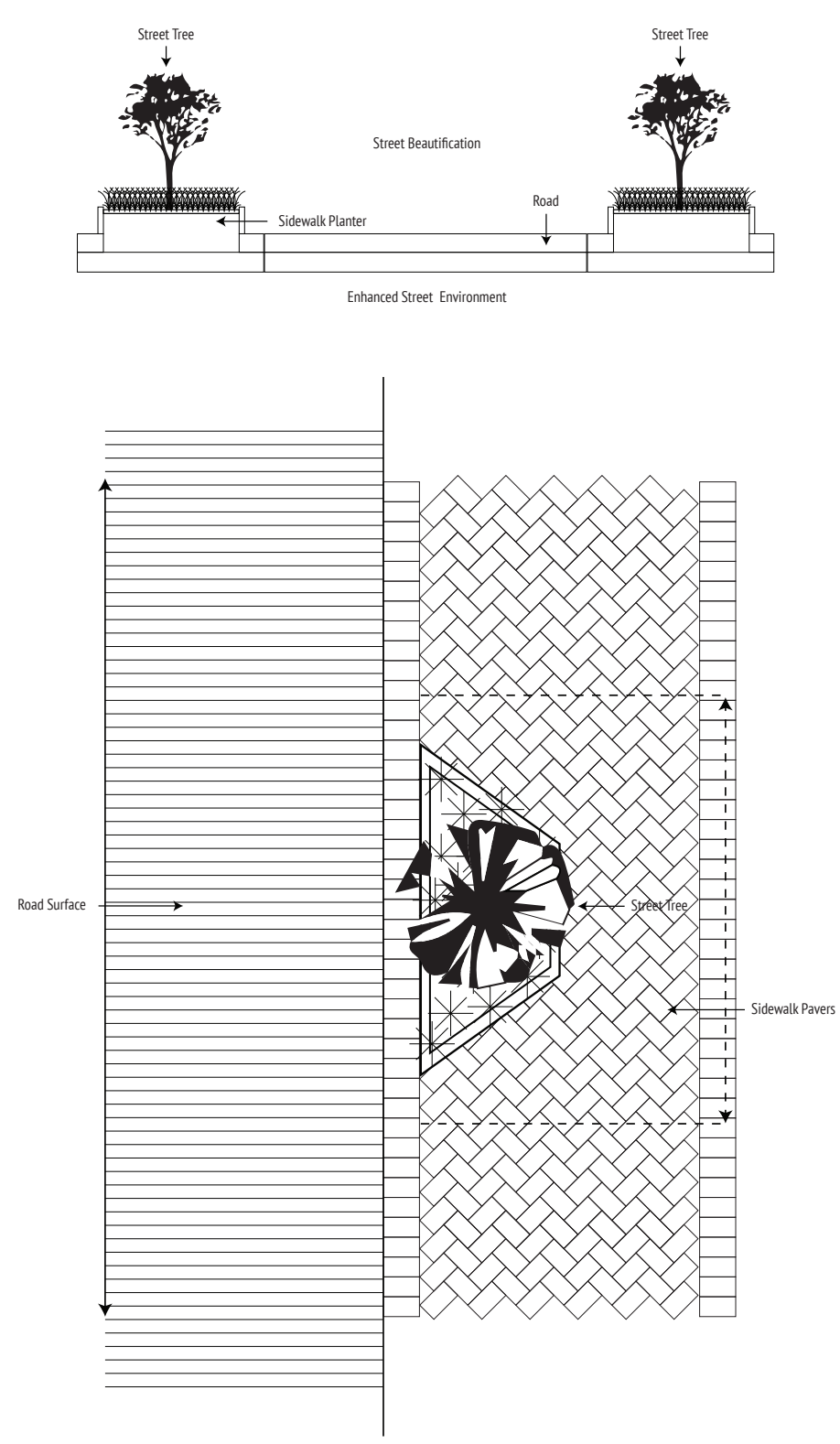

Fig. 96: Street Tree diagrams

\section{WETLAND CATCHMENT}

The current water catchment and streams located on the corner of Te Hiko Street and

Titahi Bay Road are highly degraded. This is the result of inadequate plant location, street layout, piping infrastructure and limited water retention plants situated in and around the water catchment. The existing water catchment allows overflow and unfiltered water to enter the Porirua Harbour. Incorporating wetland plants in and around the water catchments edge will enable the catchment to process unfiltered water before it enters the harbour. This will also enable retention of excessive overflow in the catchment.

Filtration and retention of water overflow can be achieved by incorporating native plants that are not only resourceful and significant to Māori culture but are relevant to the specific area and functional within the environmental system. These plants are Toetoe, Oioi, Harakeke (Phormium tenax), Hukihuki (Coprosma tenuicaulis) and Pūrei (Carex secta). These plants are also known as rongoā plants because of their medicinal value to Māori.
New planting and the utilisation of existing plants on the site is another essential and effective way of mitigating current environmental issues. This will enhance the overall aesthetics of the site provide interest the users, relate to the pathways and wate bodies and enable more interaction between the users and the environment. Relocating plants to more suitable areas that are prone to flooding and exposed to environmental issues will allow the plants to process the overflow of water and filtrate the toxins before entering the harbour catchment. This idea intends to mitigate the current flooding issues in the area while providing a natural system that will allow fauna and flora to thrive as they once had before. Although the size of the catchment will have no significant effect on the harbour, it will demonstrate the importance of restoring waterways and eventually cleaning the whole harbour catchment. This will reference the past landscape. 


\section{PATHWAY CONNECTIONS}

The existing pathways in the site lack

connectivity from one entrance to the other.

There is no sense of invitation or vibrancy

drawing users to the area. Applying directive

pathways with openings will provide a

solution to these problems. These pathways will become purposeful and create a link

between various design features within the wetland park that tell a story. This aims to

create connectivity, not only physically but also environmentally and culturally.

The pathways will consist of a variety of different surface materials. Concrete paving will create a suitable and pleasant surface

for all users, whether that be on foot or using various mobility devices. The pathways will include a new bridge to replace the existing one and significant cultural features will be incorporated to enhance the overall cultural connections.

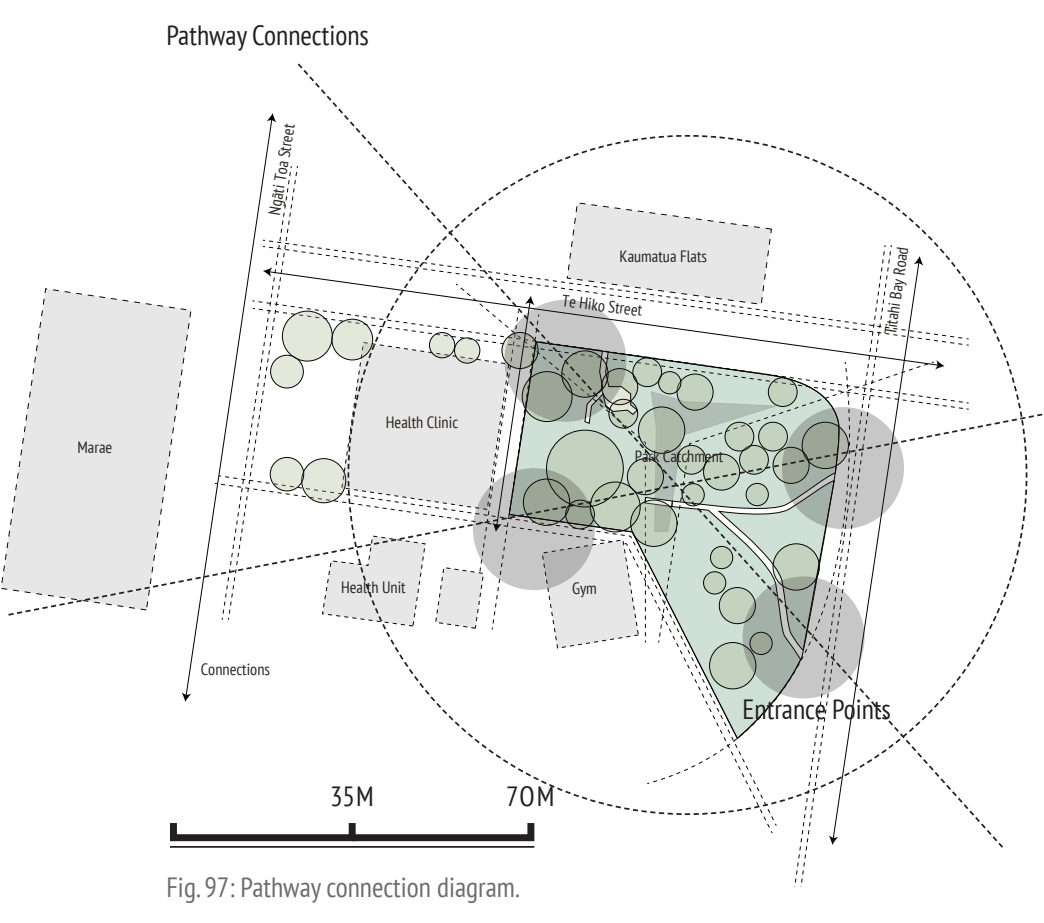

\section{DESIGN FEATURES}

The wetland park will incorporate various design features unique to Ngāti Toa that will play a part in the overall story. Each element will have a significant meaning to the iwi and will be a part of a journey that creates interaction and encourages connection between the users, their culture and the environment. These interactions will be through water features, social spaces, surface materials, statues and environmental connections.
(๑)

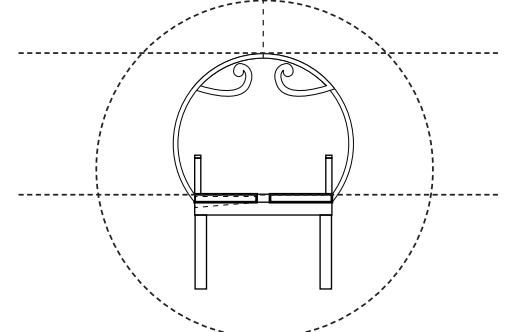

Koru Canopy Symbol

(อ)

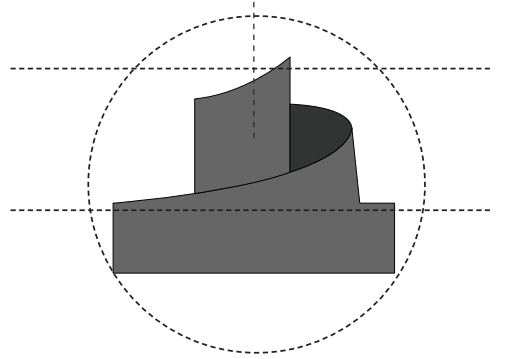

Koru Water Feature
TE WHEKE MANGOPARE KORU

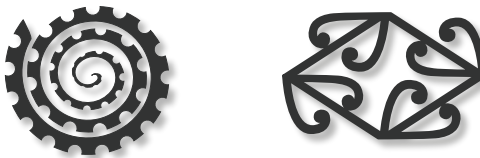

HAMMERHEAD

SHARK

Fig. 98: Măori symbol patterns
हृे

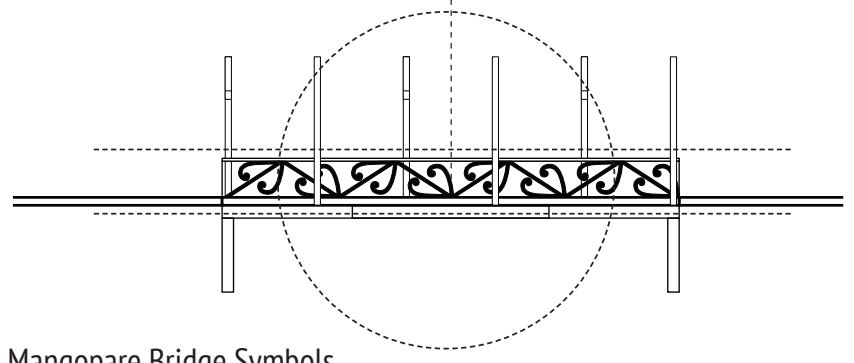

Mangopare Bridge Symbols
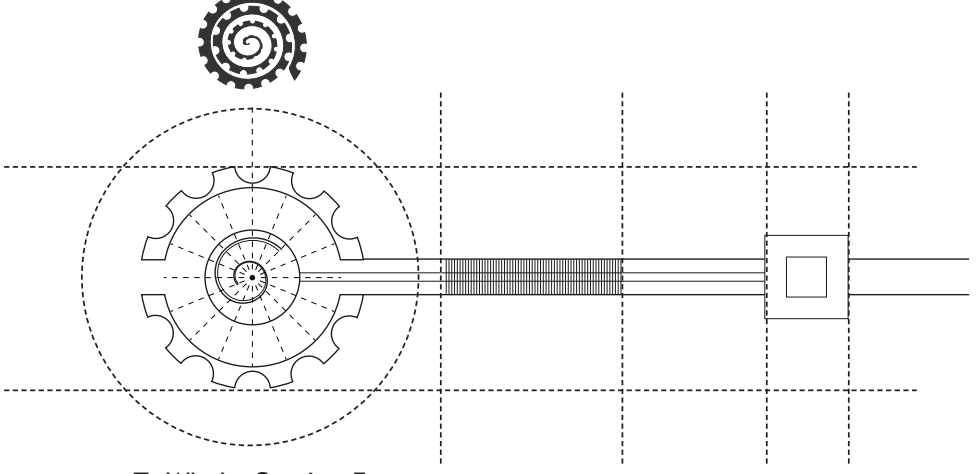

Te Wheke Seating Features
Fig.99: Mäori symbol design integrations

\section{(}

FERN SPIRAL 
DESIGN DEVELOPMENT

Spatial Relationship

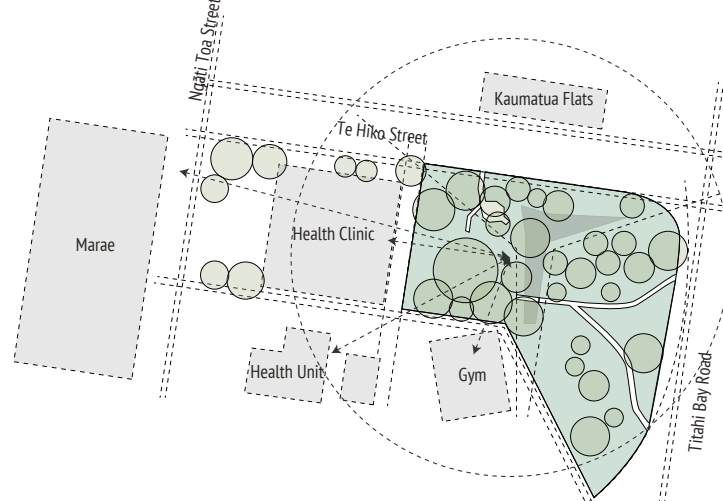

Design Implementation

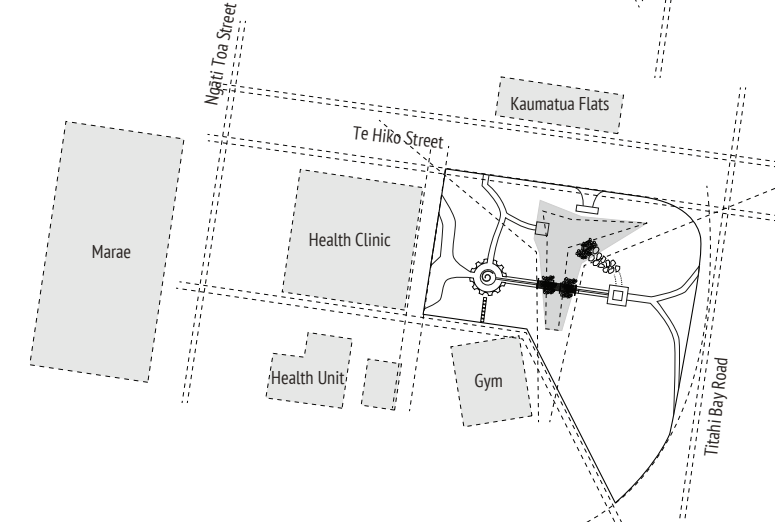

Vegetation Design

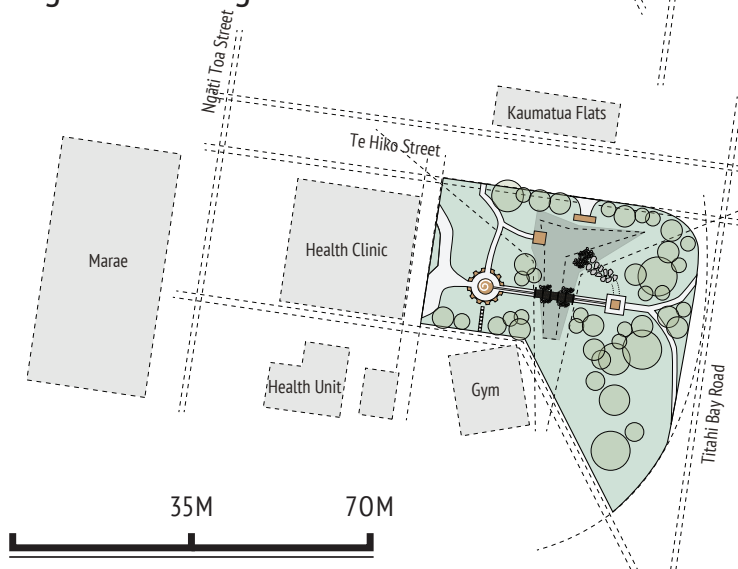

Fig. 100: Design development diagrams
DESIGN EVALUATION

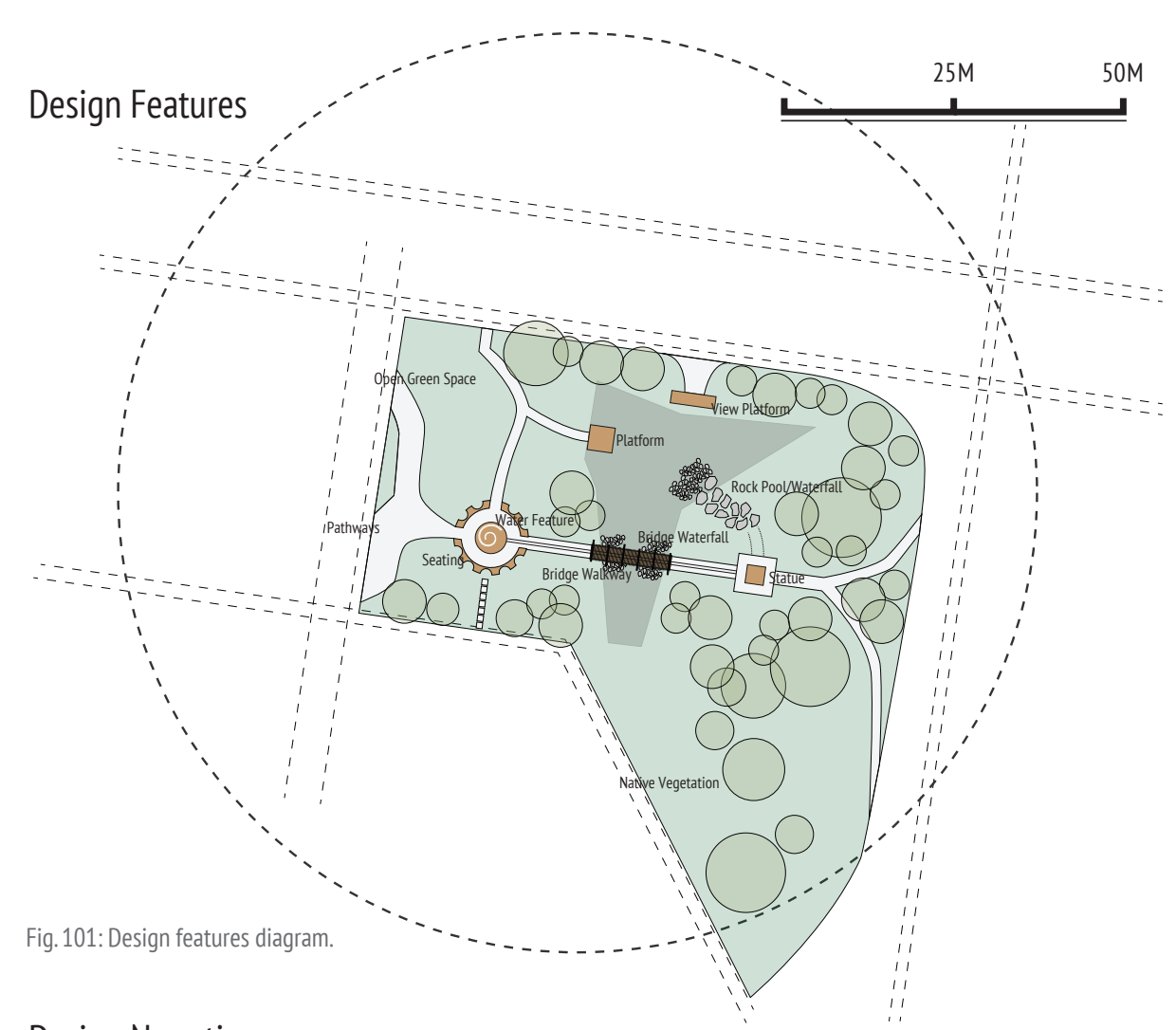

Design Narrative

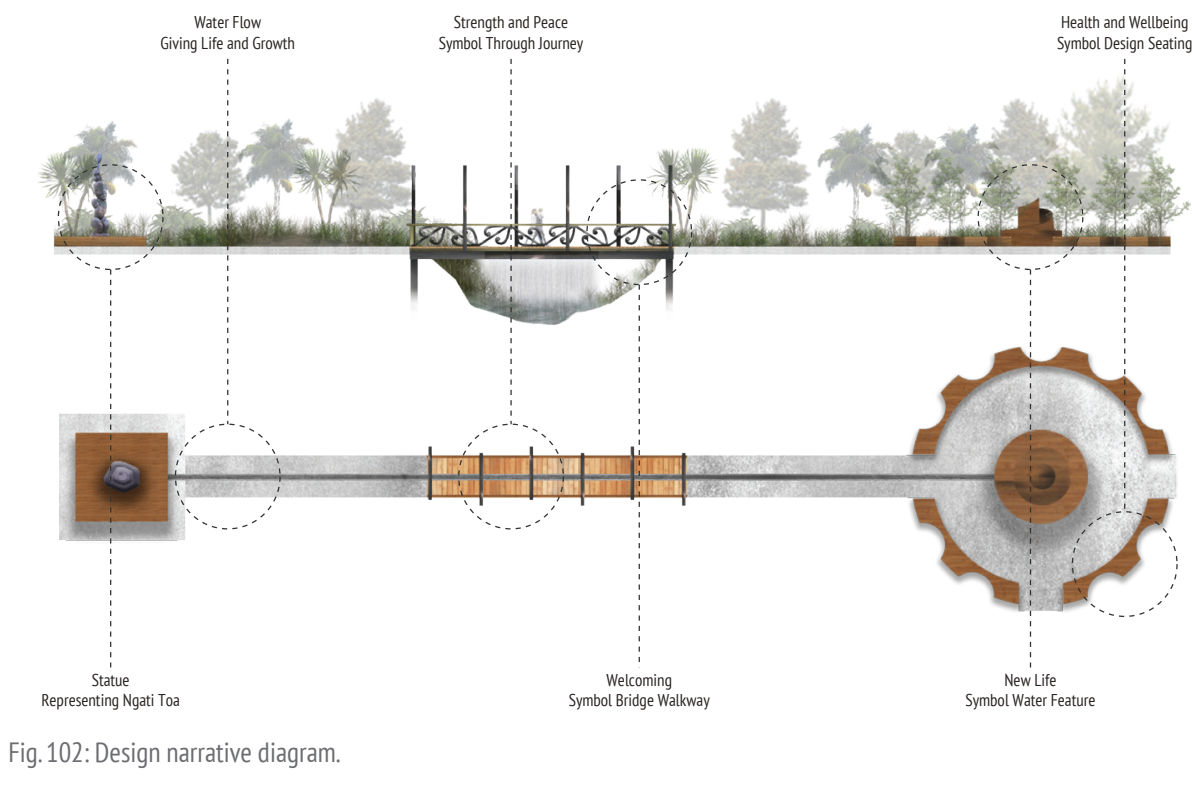


DESIGN OUTCOME

$C^{N}$

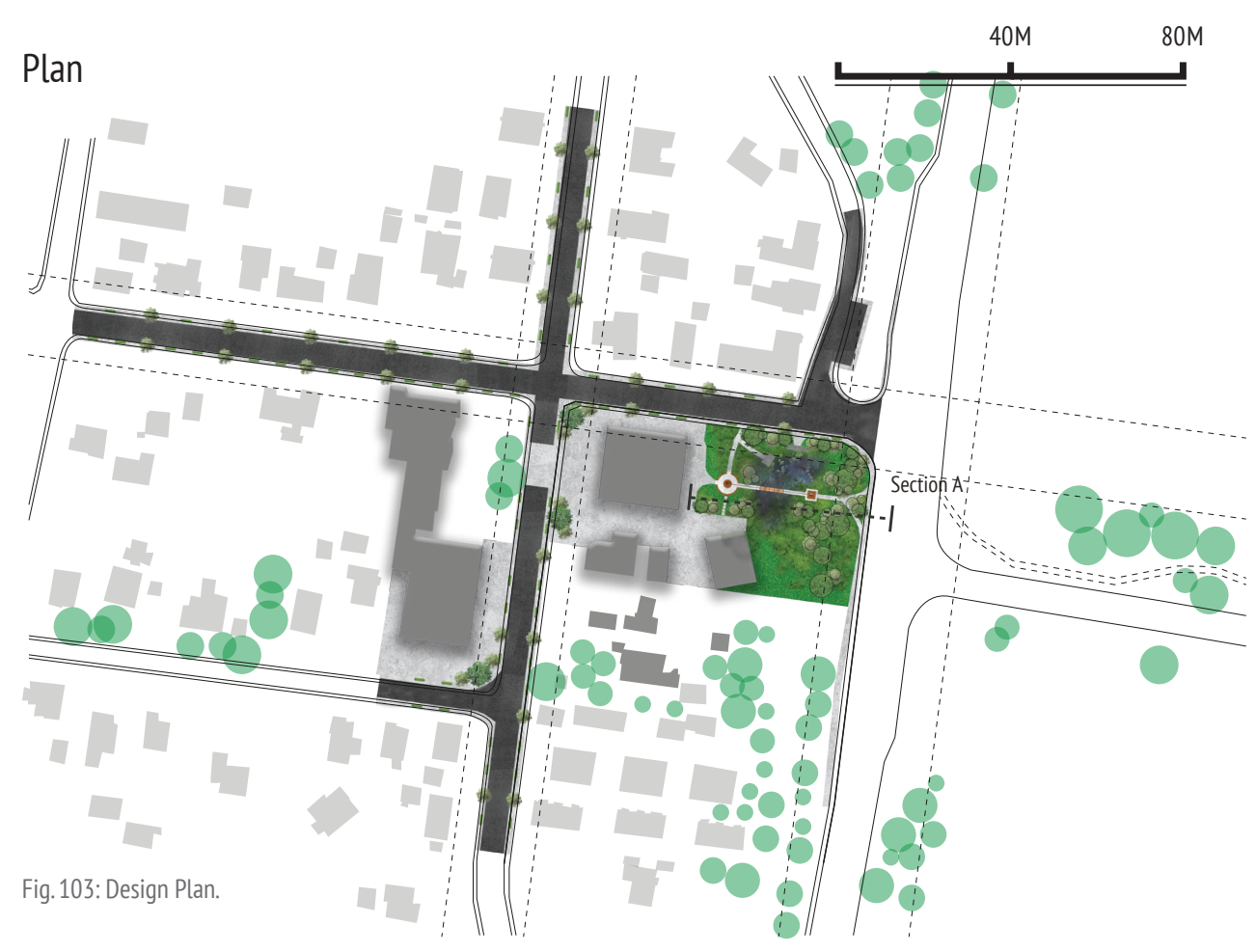

Section A
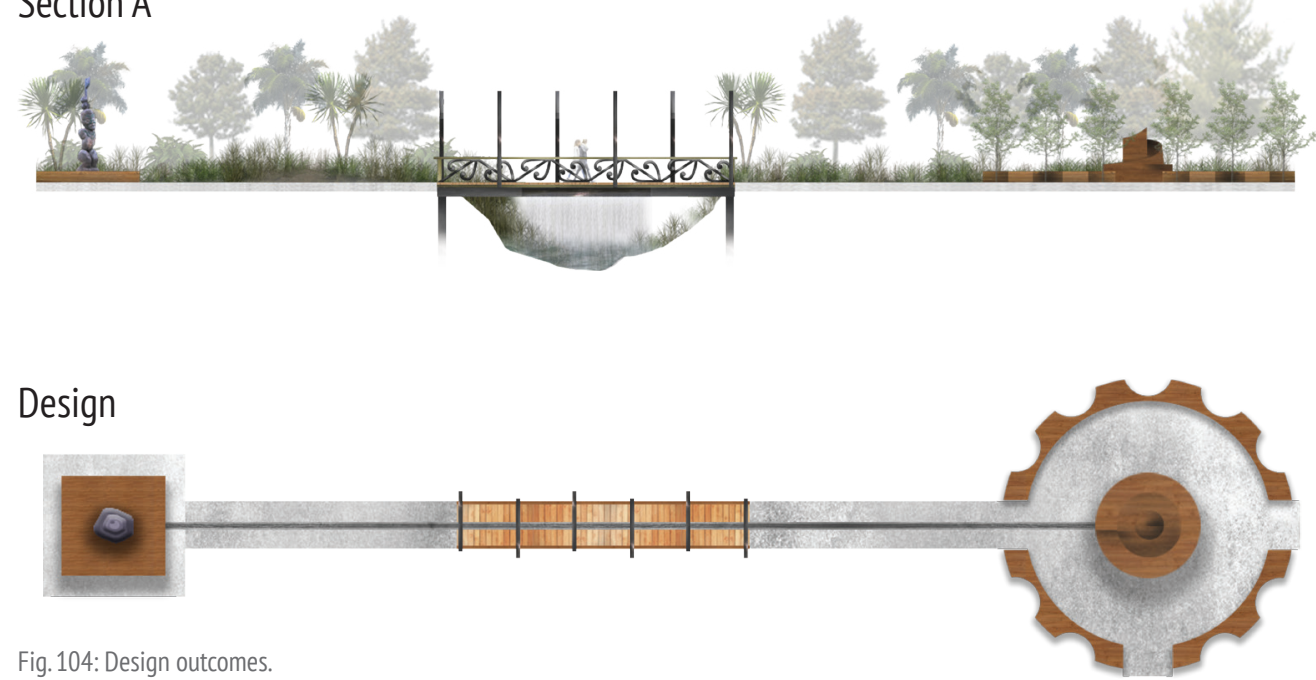

DESIGN PERSPECTIVE

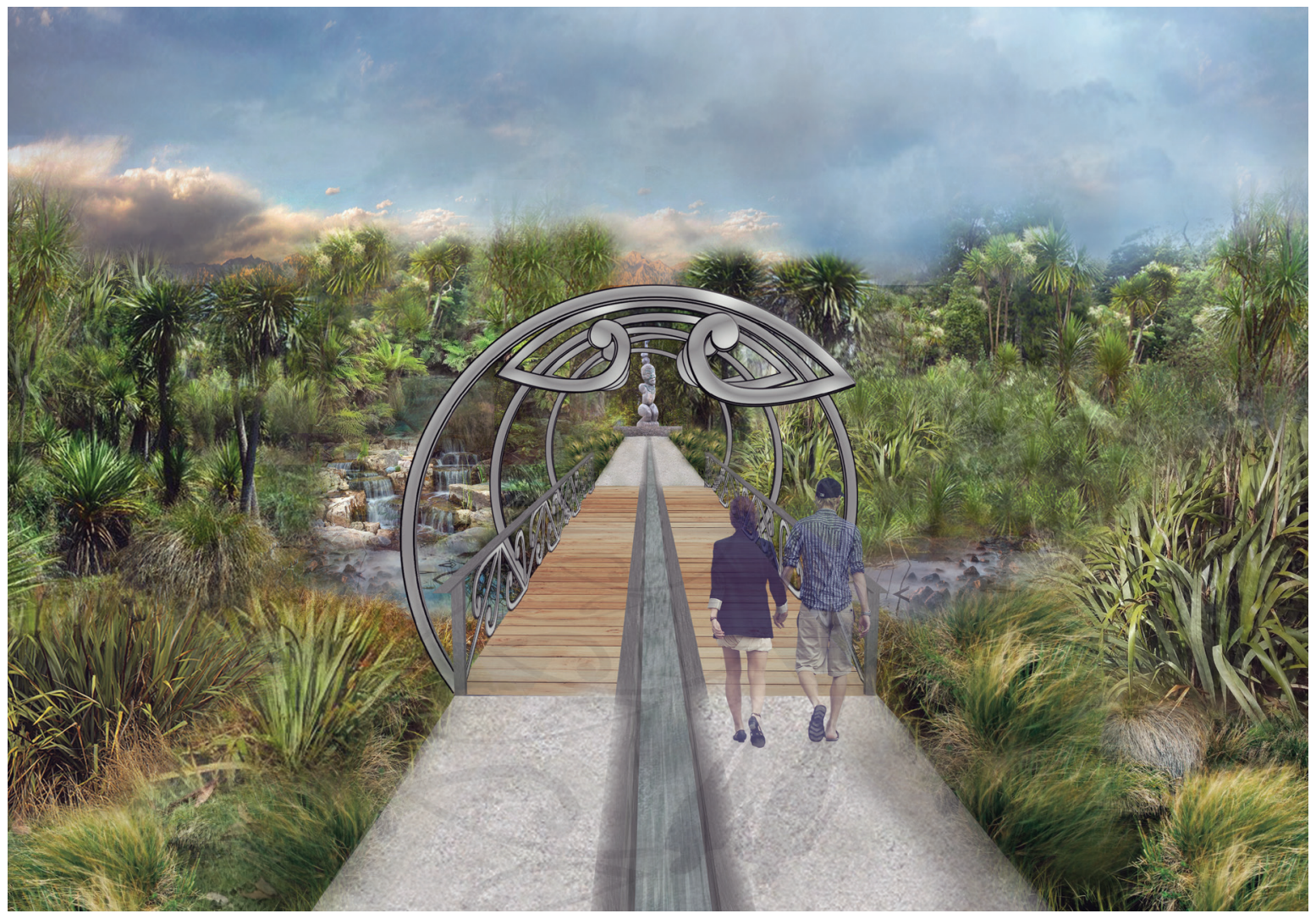

Fig. 105: Design perspective.

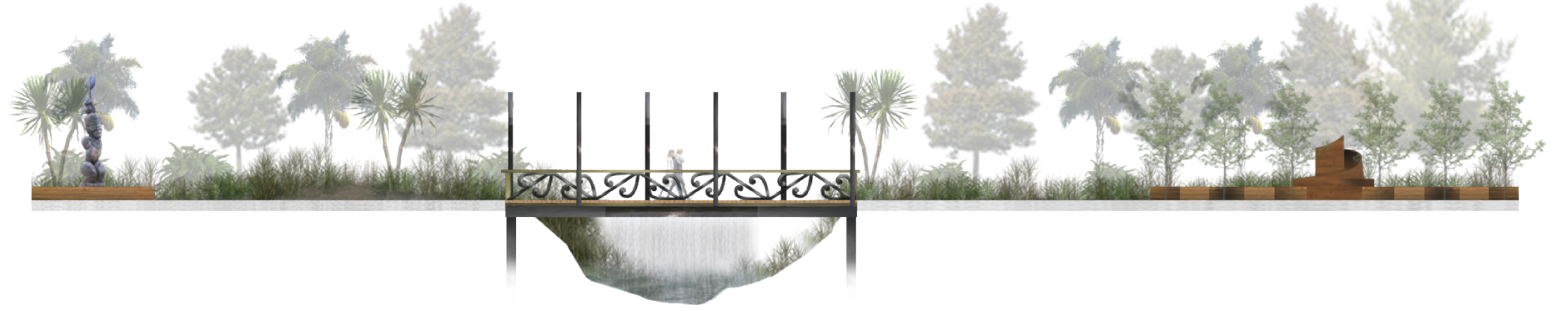

ig 106: Design section 


\section{FINAL DESIGN PHASE}

ENGAGE WITH COMMUNITY AND COUNCIL / ANSWER QUESTIONS /

DEVELOP DESIGN / REFLECT
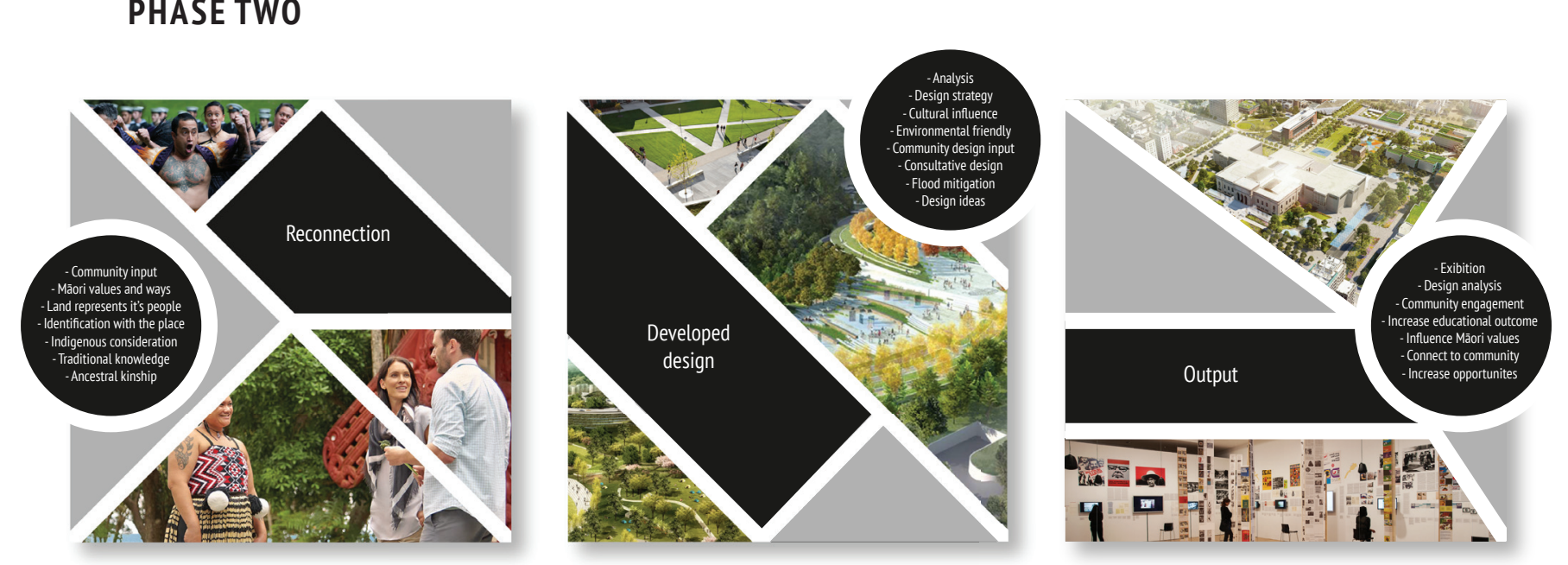

Fig. 107: Phase two diagram. 


\section{Consultative Design}

\section{PHASE TWO}

The second design session was held with the Village Planning groups from the Porirua City Council and Te Rūnanga o Toa Rangātira (iwi authority and administration group). This was a consultative design session that started with an overview of the issues currently plaguing the community as presented in the first session. One key issue concerned roading through lack of pedestrian friendliness, vehicle speeding, flooding and the lack of connectivity to the marae. The other key issue was problematic Te Hiko Street corner. The problems were previously addressed in the first design session with evidence of degradation to the water catchment, environment and overall neglect of the site.

Accompanying the overview a design proposa was presented which had been developed in response to the issues and ideas that were expressed in the previous participatory design session. These initial design proposals were backed up with research and further analysis that followed the first session.
The design proposal included an introduction of Green Street Design principles with a change in surface and an introduction of greenery to the street. The road would now be on a single level, from sidewalk to sidewalk. This will help eliminate the transition from a pedestrian-friendly surface to a vehicle dominated surface. In the proposal the street/ sidewalk space is now pedestrian-friendly and an open walkway that allows vehicle access. Permeable paving enhances pedestrian friendliness while creating retention to surface water overflow and dictating vehicle speed. The use of permeable paving also aids wate retention as it has the ability to store surface water.

The next part of the discussion looked at the Te Hiko Street corner. This corner was an issue for the iwi in need of attention. The suggestions and ideas from iwi members were similar to those that came out of the previous Participatory Design session. The initial design proposal developed in response to the first participatory session met with praise and encouragement.
There were a couple of minor suggestions made by the iwi and the community, such as, incorporating particular plants such as kotukutuku, which invite honey-eating birds such as tūi, bellbirds and silvereyes, and more rongoā plants, which are significant to the iwi. Recommendations were made about who the pou whakairo (Māori carved sculpture) should represent. They considered it needed to be someone significant to the area and the environment. It was decided that the most appropriate was Te Hiko-o-te-rangi, as Te Hiko was a great chief of Ngāti Toa and was influential in the Ngāti Toa people settling in Takapūwähia. The statue would relate with the existing scenic walk around the harbour's edge that celebrates the rich legacy of writers and playwrights from around Porirua. The Writers' Walk is a project to enhance the pathway skirting the edge of Wineera Drive and Te Awarua-o-Porirua Harbour, with sculptures celebrating the city's rich writing history. The statue located on the southern end of the harbour pays tribute to former Ngăti Toa chief Te Rangihaeata. This statue will correspond well with the new representation of Te Hiko as Te Rangihaeata was a leader alongside Te Hiko's father Te Pehi Kupe and Te Rauparaha. Te Hiko also shared a close relationship with Te Rangihaeata and was living at the pã of Te Rangihaeata on Mana Island. The pous (carved wooden posts) of Te Hiko and Te Rangihaeata stand together as the two centrepieces inside the Takapūwāhia Marae wharenui representing their importance to the Ngāti Toa iwi, standing strong and holding the structure together as they stood strong to keep their people together.

This proposal aimed to tell the story of the rich history and influential people that made Ngāti Toa, and to make the community stronger as one, as it once was under the guidance of their tippuna and leaders. Overall, the proposed wetland park and green street designs were met with great enthusiasm by community and council members. 

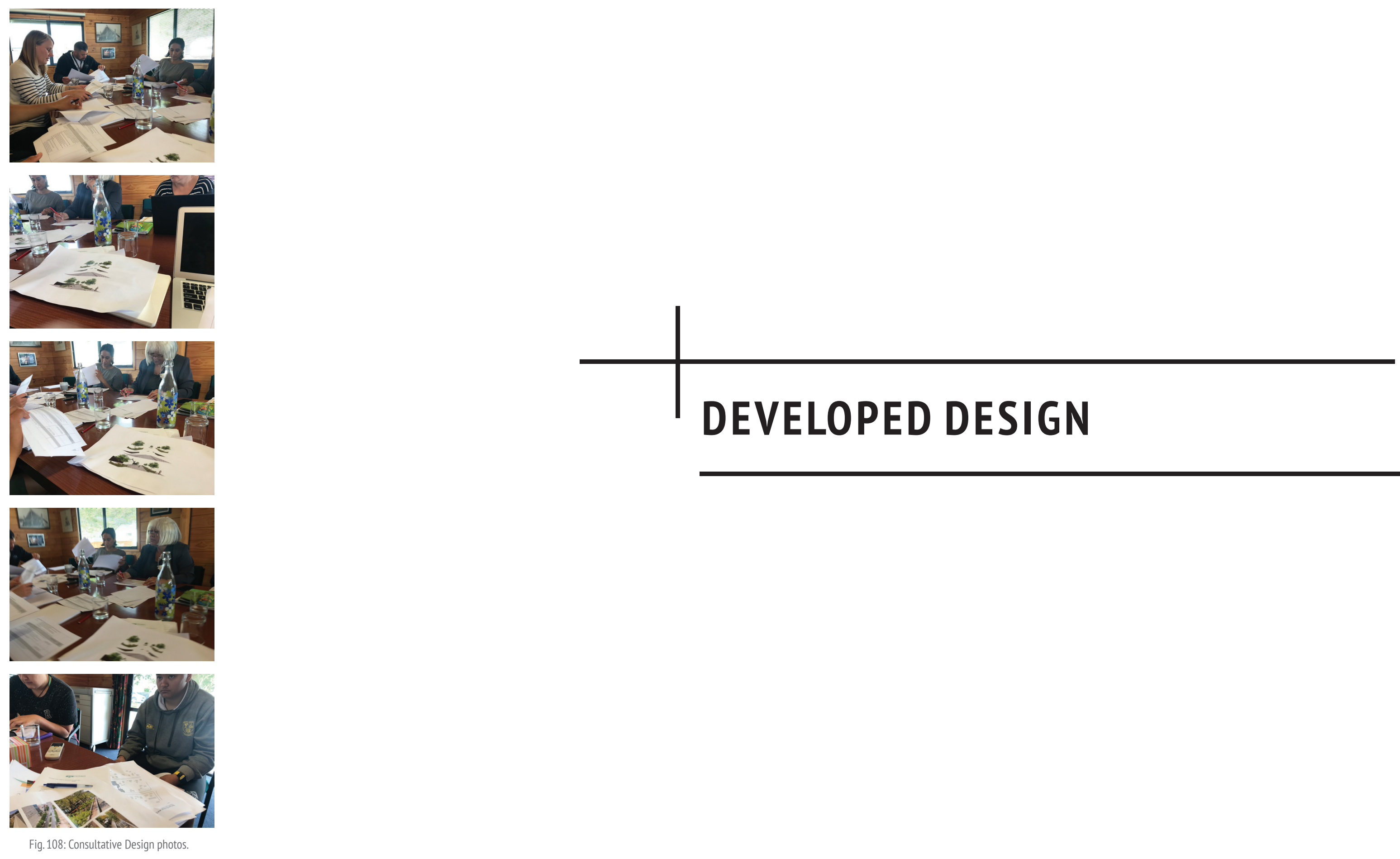

DEVELOPED DESIGN 


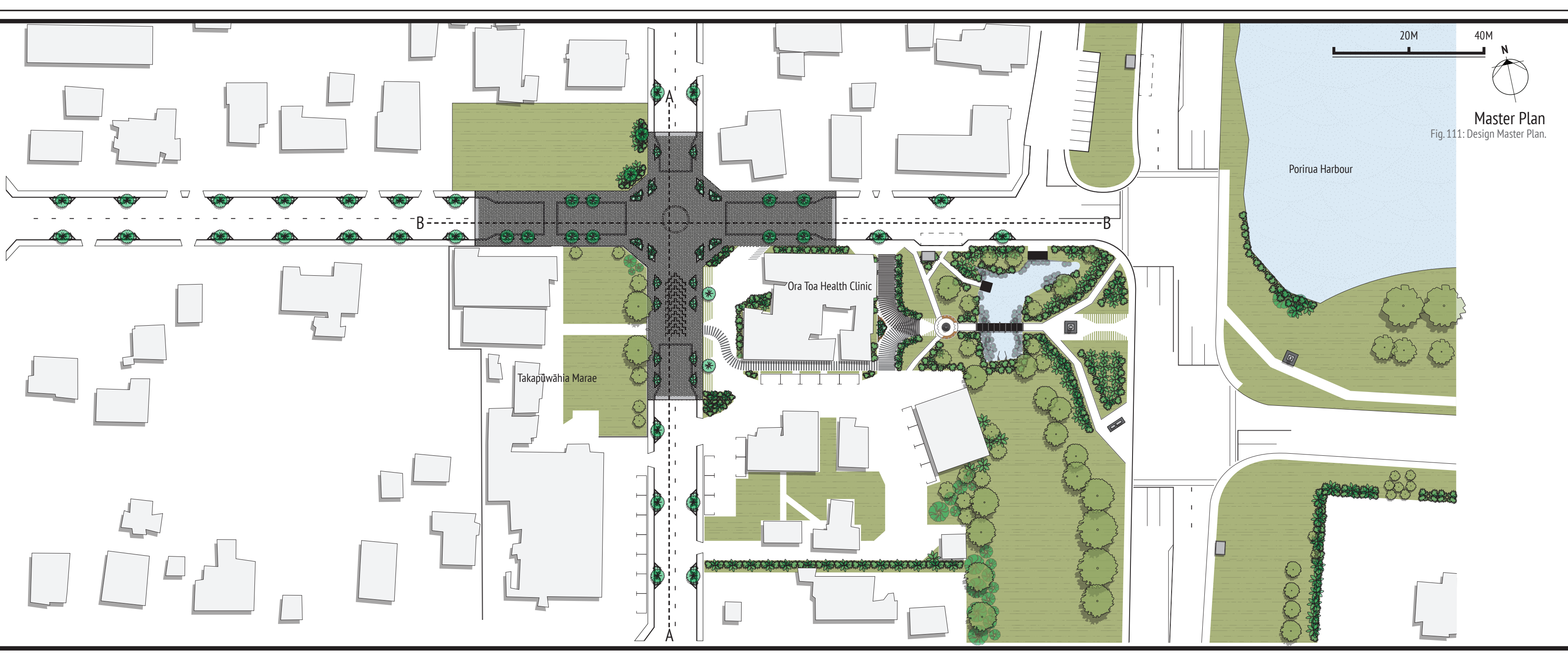

New Ngāti Toa Street Section A Fig. 112: New Noăti Toa Street.

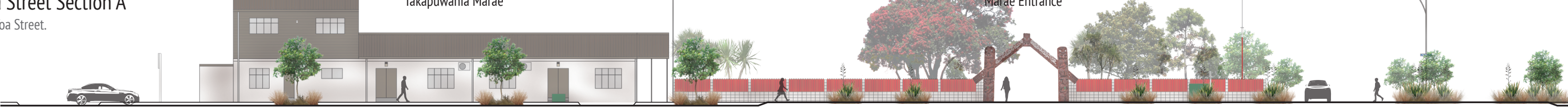

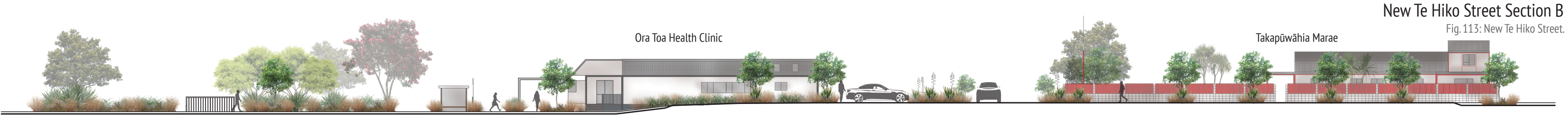




\section{Green Street Design}

PERMEABLE PAVING

Permeable Paving:

Permeable paving will be applied to sections of Te Hiko and Ngāti Toa Streets along the Takapūwāhia Marae vicinity. These concrete pavers will form a symmetrical weaving shape to elaborate the influence of tukutuku (weaving) design. Not only will this enhance the aesthetics of the street but also apply functionality towards water retention and pedestrian friendliness. The pavers will cover the surface from the one end of the footpath to the opposite pathway. The street surface will consist of concrete pavers that will be applied in unison throughout the street. The pavers will be complemented with road markings and signage that will define vehicle and pedestrian zones. The transition from the existing road to the permeable surface will elevate the

road level with the footpath. The elevation of the road surface to the level of the pathway will dictate vehicle speeds and promote a pedestrian hierarchy to the street.

The new permeable surface will consider all environmental issues and auto-oriented hierarchy and intend to mitigate these problems. The promotion of pedestrian hierarchy is especially crucial for the streets surrounding the Takapüwāhia Marae.This allows for a more fluid street and marae connection while bringing a sense of safety on the road.

The permeable surface will incorporate cultural influence into the orientation of the pavers. The pavers will represent the tukutuku pattern of Whakatupuranga Rua Mano (see fig. 85-86). This pattern symbolizes the achievement in reaching full potential in all aspects of one's personality and abilities. These abilities suggest the never-ending capacity of fulfilment and an extension of never-ending connection. This pattern is to show appreciation to the Ngāti Toa people, and their high chiefs who are known as strong and noble people and their relationship to their people will be passed down generation after generation.
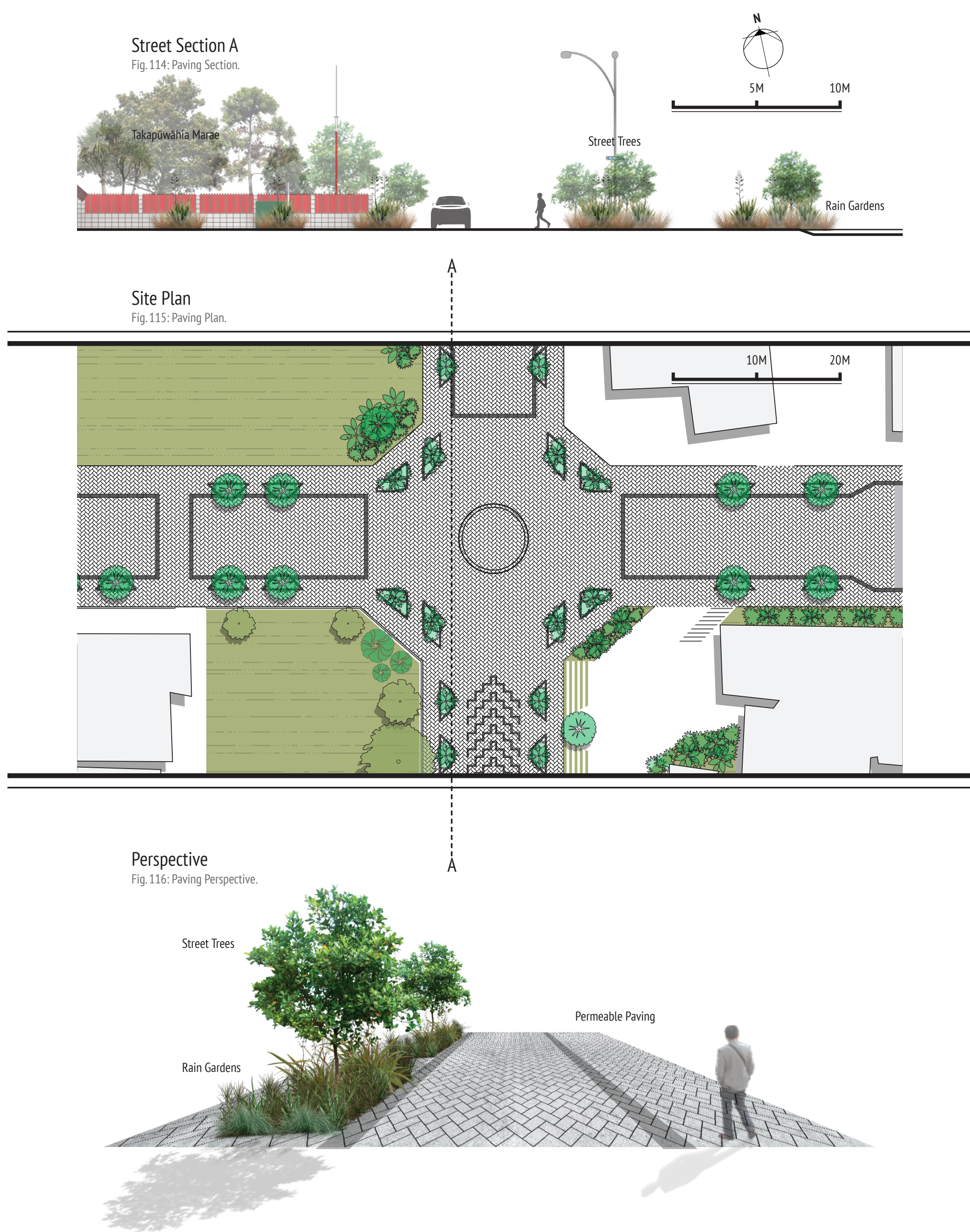


\section{RAIN GARDENS}

Sidewalk planters and vegetated curb extensions will be integrated throughout Te Hiko and Ngāti Toa Street. These rain gardens will consist of native plants such as Oioi, Toetoe and harakeke, which will provide retention to excessive water and filtration for contaminated water. The sidewalk planters will form a triangular shape to correspond with

the road surface and water flow. The planters will intend to act as a water catchments for excessive surface water. The planters will be placed throughout Ngāti Toa and Te Hiko Street to create a water retention barrier. The rain gardens will collaborate with the permeable pavers on the street to slow water flow and absorb water before it reaches excessive levels. This will relieve the stress of water overflow that will apply too much pressure on the current stormwater system. The sidewalk planters will also enhance the visual experience for all street users and dictate pedestrian movements with channels and safe thoroughfare on the street.

The vegetated curb extensions will consist of the same features as the sidewalk planters, although the consistency of the curb

extensions will vary due to the road layout

amongst the surroundings. The rain gardens

will have the same attributes as the planters but with different intentions for the street The curb extensions aim to direct traffic and create safer passages for pedestrians on the street. They will also be used as natural stormwater retention barriers to compliment the sidewalk planters. The vegetated curb extensions will be located on the corners of Te Hiko and Ngäti Toa Street and along flood-prone areas situated outside the Te Hiko Street wetland.

An excellent example of ecological benefits in landscape design is evident in 'Case Study 3 - La Rosa Reserve Stream Daylighting'. La Rosa Reserve identifies natural systems and the importance of creating opportunities that benefit the environment. This is expressed through the stormwater management plan at La Rosa that emphasizes using natural methods to replace artificial systems.
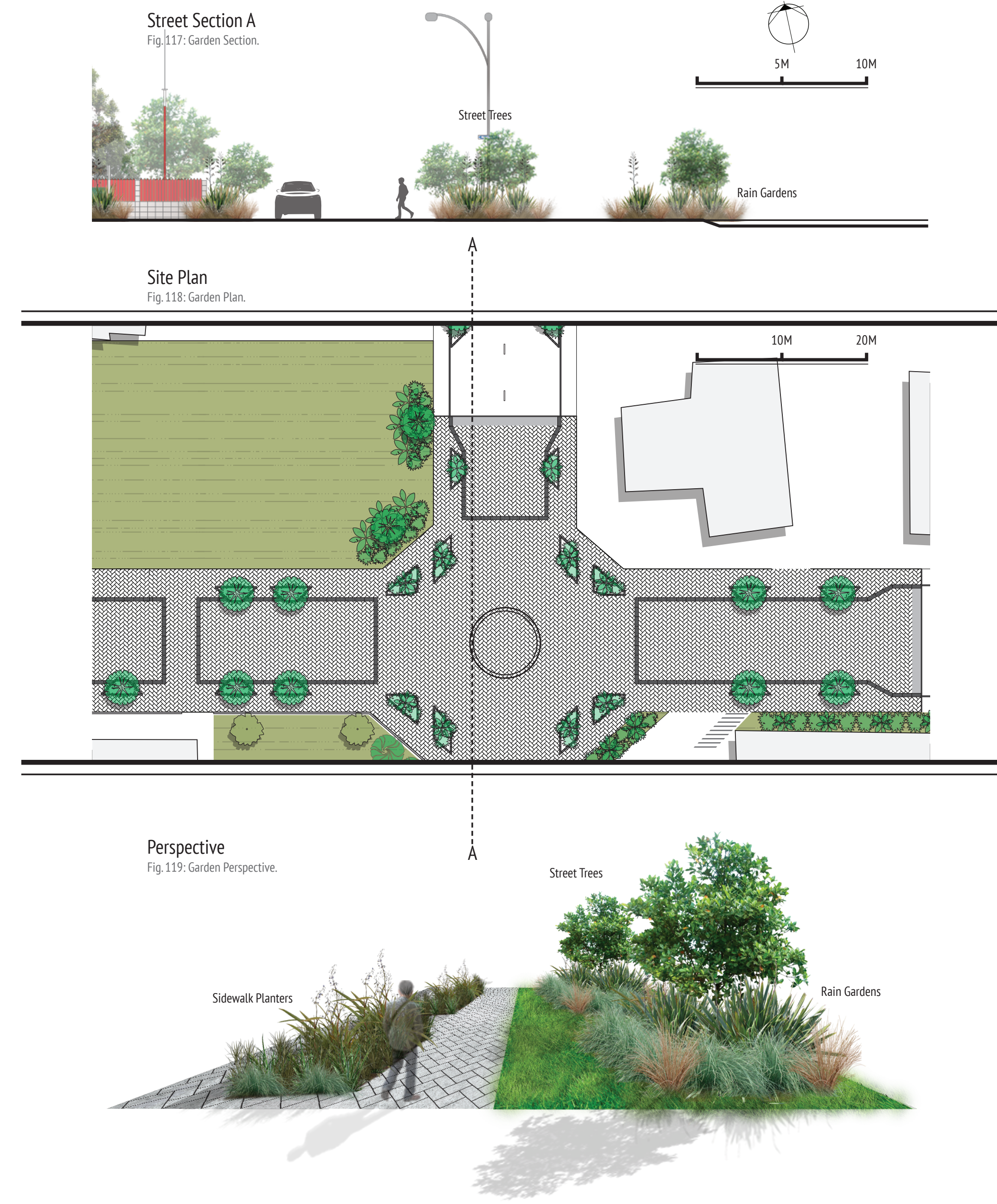


\section{STREET TREES}

Street trees give a place vibrant, visua attractiveness, environmental security and invitation. Incorporating Titoki (Alectryon excelsus) to the rain gardens will bring all these attributes to Te Hiko and Ngāti Toa Street. Titoki are an attractive canopy tree that grows anywhere between 4 - 18 metres high. These trees reveal their beauty through glossy dark-green leaves and its spreading canopy.

Māori identify titoki as rongoā (medicinal),

where they used to bruise and steam the seeds to release its rich oil. The oil from these seeds are essential to Mãori who would reap the

medicinal benefits they provide. The oil was

used for earaches, eye problems and as a lotion for a wide range of skin ailments.

Aside from its medicinal attributes, titoki require low maintenance and can thrive in the Takapūwāhia environment. These trees can be integrated into the rain gardens throughout the street without any significant implications. Titoki can help create a safer walking

environment by displaying formation and establishing visual walls that provide distinct edges to the road. This allows motorists to better distinguish between the auto-oriented environment and the pedestrian-friendly environment.
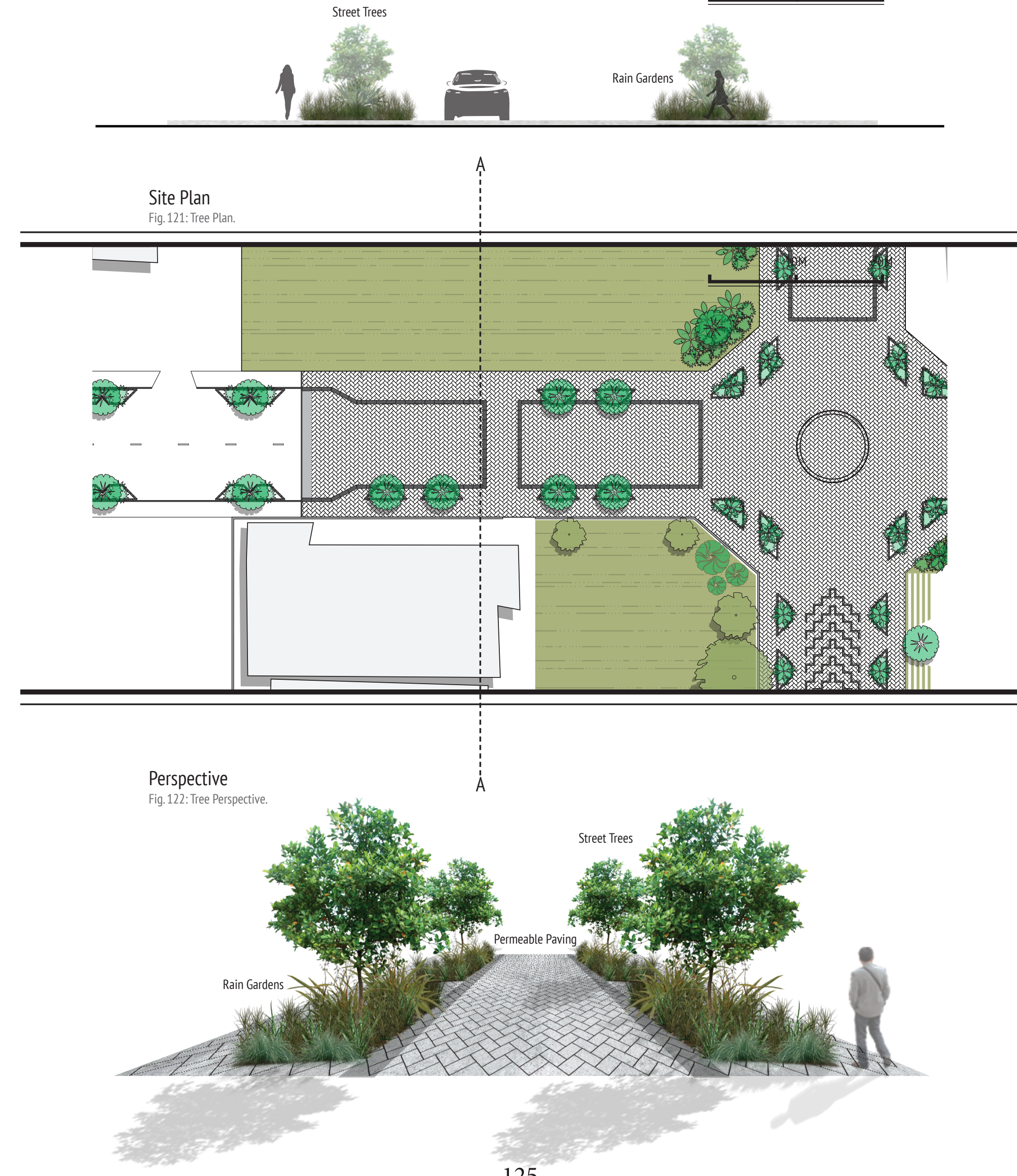


\section{STREET PATTERNS}

Located on Ngāti Toa Street, directly outsid the Takapūwāhia Marae waharoa (gateway), will be a marking on the street surface. This marking will represent the tukutuku pattern of Nga Kete Matauranga. This pattern pays homage to the three baskets of knowledge which Tane received when he climbed to

the highest heaven. The three baskets of knowledge have an important place in Māori mythology. The three baskets are also a

representation of the three words of welcome and farewell.'Haeremai, haeremai, haeremai' which commemorates the welcoming onto the marae and 'haere, haere, haere' which commemorates the farewell to the deceased. This representation of welcoming and farewell correlates well with the street and the marae. The specific area where the marking is situate is significant to Ngāti Toa people. At this point, people are welcomed on to the marae, and the deceased are farewelled from the marae. This is particularly important because the decease are then carried on foot by family from the

marae to the urupa (cemetery) from this point

The Nga Kete Matauranga pattern can honour the decease by wishing farewell on their final journey to their resting place.
The Nga Kete Matauranga pattern is built up by a simple repetitive unit that crosses over diagonally and creates a weave effect (see fig. 83-84). This pattern is represented in various forms of weaving and carving. Traditionally, weaving is done with harakeke to create essential items such as baskets. Sections of harakeke plotted along the street will complement the Māori pattern and its representation Nga Kete Matauranga along Ngāti Toa Street. The pattern will be engraved into the paving surface of the road.

An excellent example of Māori surface patterns incorporated in design is evident in 'Case

Study 5 - Freyberg Place'. This project worked with a local iwi artist to come up with a

design that represents the flow of water. This design depicted Māori symbolism, and a Māor pattern was engraved into a stone surface to compliment the actual water flow at Freyberg Place (see fig. 43).
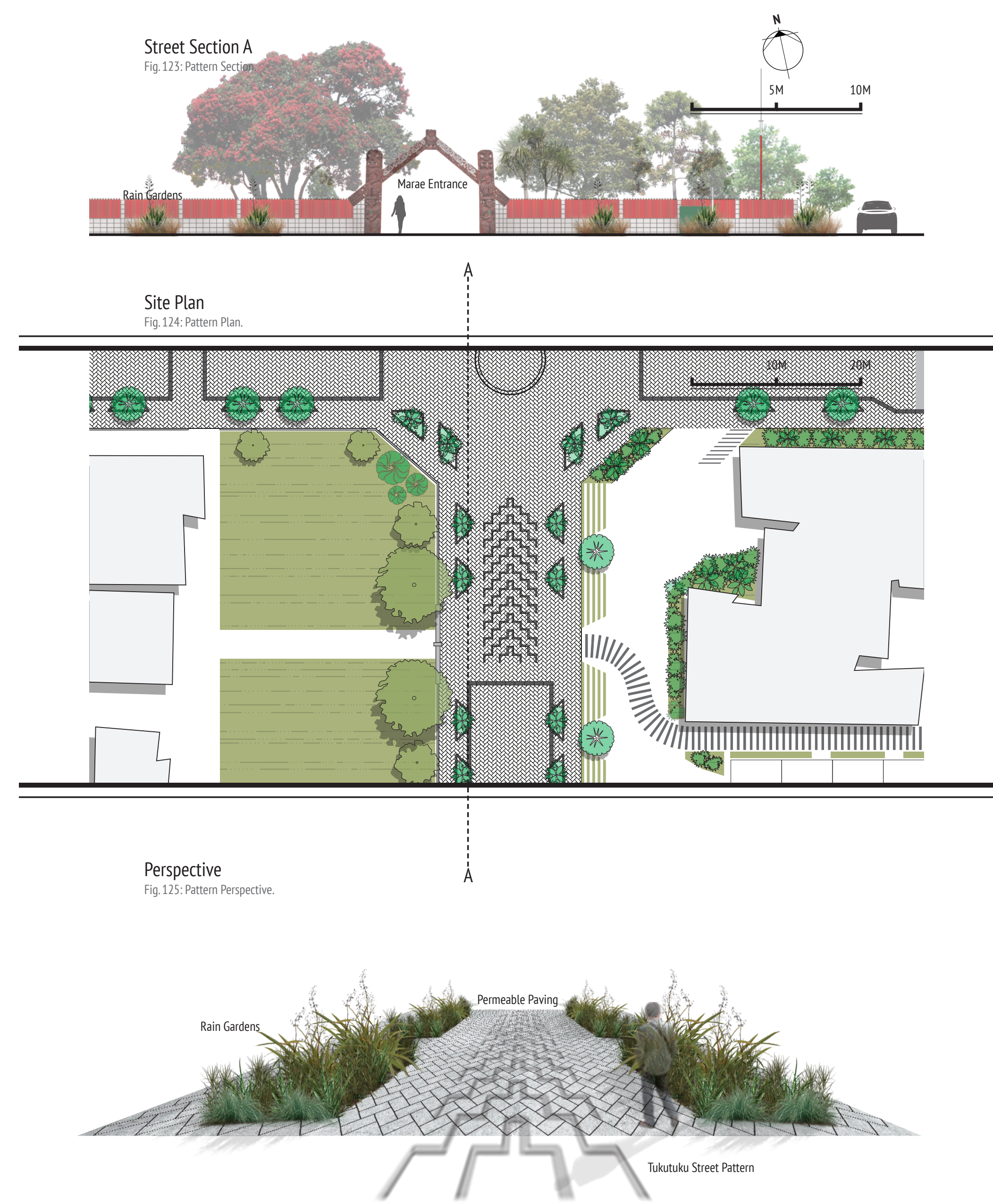


\section{Te Hiko Wetland Park}

\section{VEGETATION}

The Wetland Park will consist predominantly of rongoā (medicinal) plants. Rongoā plants are essential to the development and sustenance of Māori people. These plants allowed for

traditional practices of Māori medicine and weaving through the utilization of plants such as harakeke. The existing site is highly degraded. Therefore the relocation of existing native plants and the incorporation of new

native plants such as $\mathrm{Oi}$ oi and Toetoe in and

around the catchment will prove beneficial for the environment.

The use of wetland plants and various othe native vegetation will help mitigate issues of flooding, degradation of the site and environmental neglect. It will also encourage wildlife to thrive in the environment and the restoration of lost habitats. To check out the Wetland Park planting strategy and list (see fig. 126).

An excellent example of a successful planting strategy is evident in 'Case Study 1 - Kopupaka Reserve'. This project provides critical emphasis on environmental and cultural benefits.

This is displayed through the development of wetlands and promotion of ecological awareness to restore natural water systems and habitats.

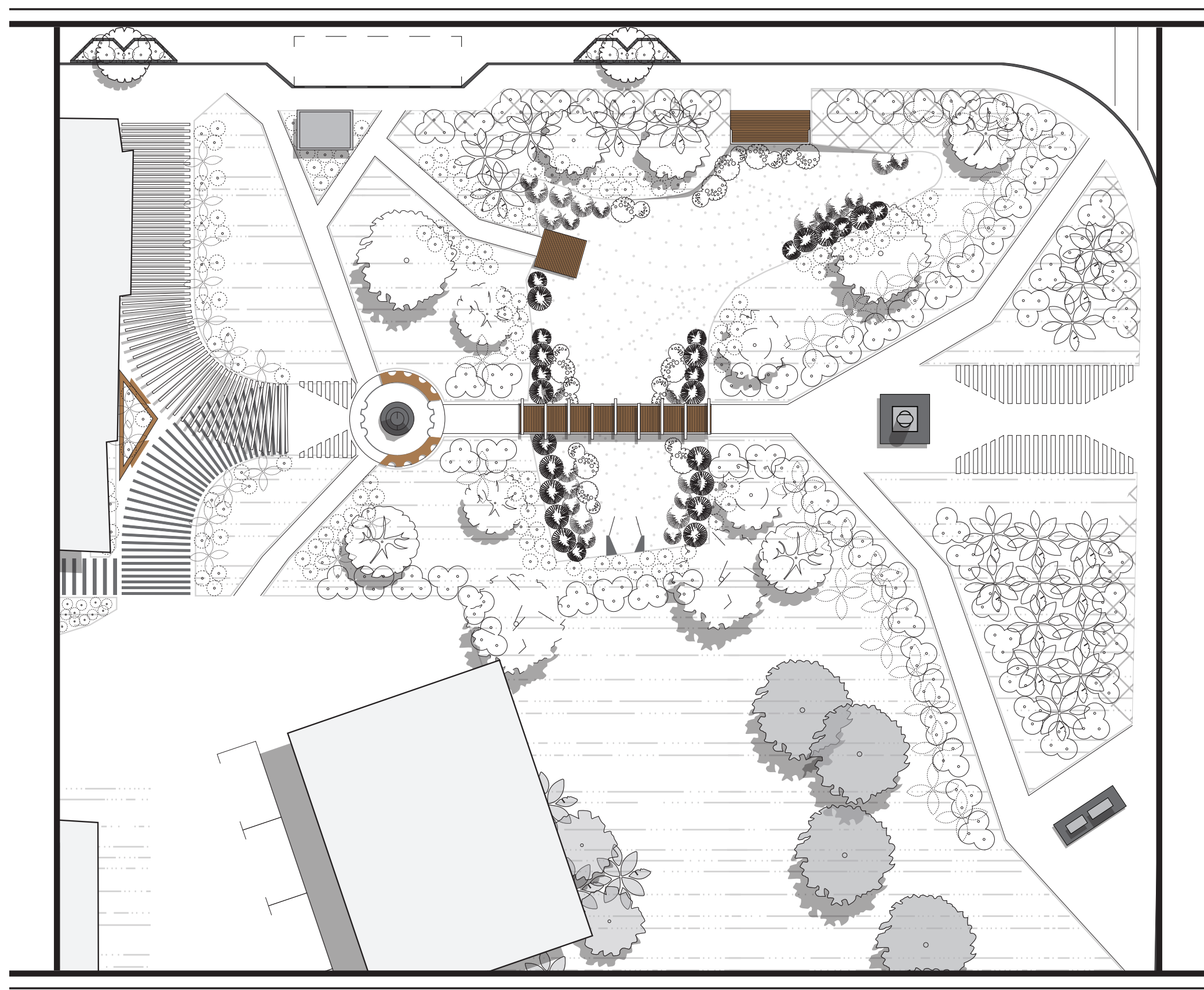

TREES

(Alectryon exelesus) Titoki (Fuchsia excorticata) Kotukutuku (Peenanantia corymbosa) Kaikomako (Sophora microphylla) Kowhai (Melicytus ramifforus) Māhoe (Weinmannia racemosa) Kämah
SHRUBSFFLAX 3. (Phormium tenax) Harakeke b (Phormium cook

\section{SURFACES} Grass
Water

RASS/SEDGE (Austroderia toetoel Toetoe (1) (Typha orientalis) Raupō U) Isolepisis roclifere) Isolep

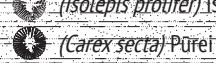

\section{GROUNDCOVER}

$\otimes($ Lobelia angulata) Panaken ExISTING
Trees
Shrubs
* Flax
Sedges 
The incorporation of a pergola at the main entry point of the Wetland Park creates

invitation, enhances the environment and

applies directive openings into the site.

The shape of the pergola provides cultural

reflection through symmetry and relation with

the surface patterns that depict the proposition

of Nga Kete Matauranga, which correlates with

'welcoming' through symmetrical patterns in

Māori symbolism.

The pergola will be made of individual timbe posts in the shape of an upside-down 'L' that

are erect from the surface. These posts will be

aligned on the main entry point of the Wetland

Park and guide the users through a channel

into the site. The pergola is just one of many

openings into the Wetland Park, therefore,

giving the user a different experience in

entering the site. The idea of having different

experiences around the site provides the

user with a sense of intrigue and encourages

exploration of the various features within site.

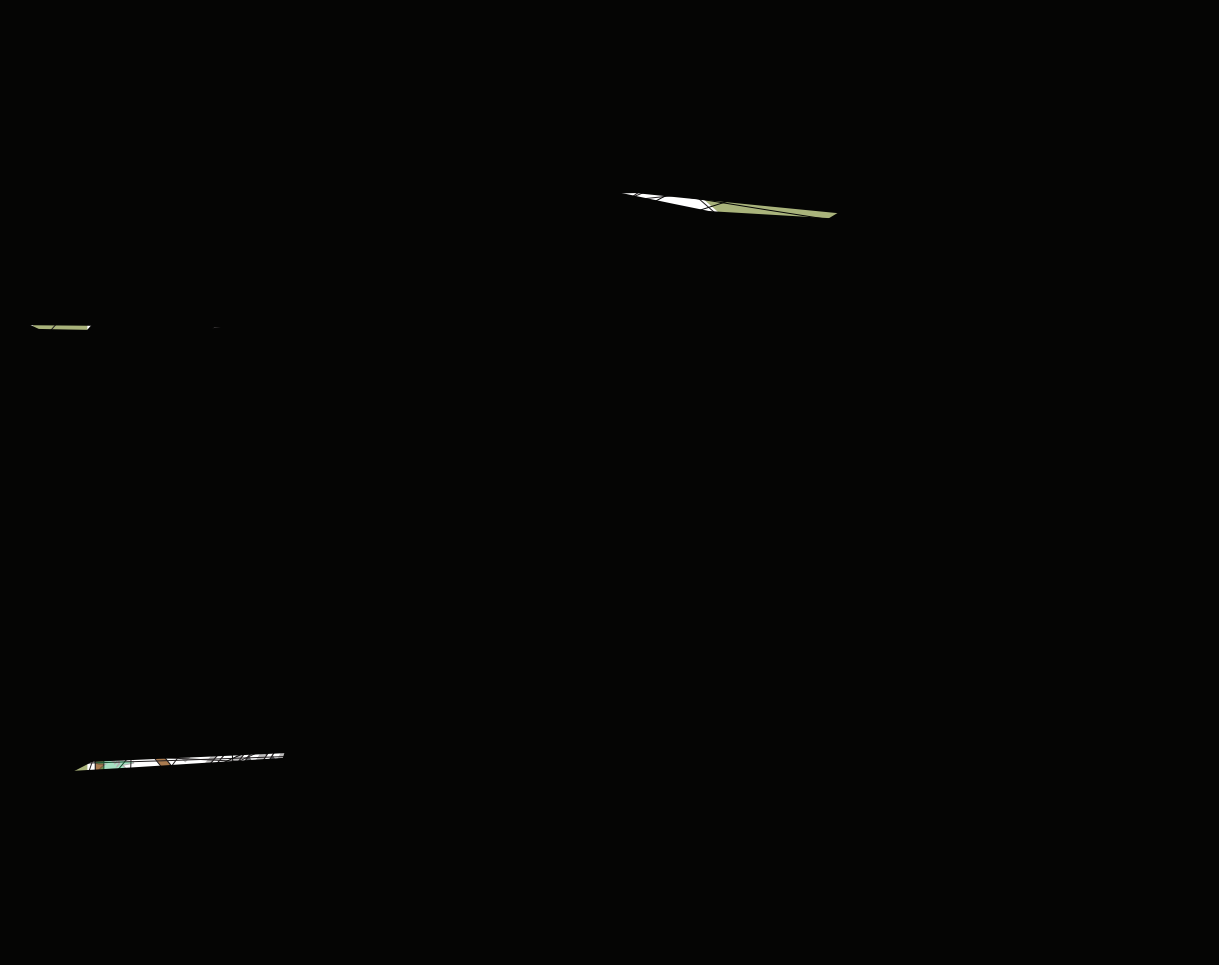




\section{MĀORI SYMBOL DESIGNS}

\section{Koru Sculpture}

Located within the pathway towards the

bridge on the eastern side of the park, lays a sculpture. This sculpture intends to be a locally

carved pou wakairo (Māori carved sculpture) that takes the formation of a koru pattern. The use of the koru pattern represents the idea of new life, growth, strength and peace in Mãori symbolism. This sculpture intends to pay tribute to the Takapūwāhia $\mathrm{Pa}$, as it provided new life and growth for the Ngāti Toa people. This sculpture will correlate with the surrounding rongoā plants that also proved vital in the growth and strength of the Ngāti Toa people. The koru will provide a piece to the overall story of the Wetland Park.

\section{Te Wheke Seating}

The symbol of Te Wheke (octopus) will be represented in the seat design surrounding the koru sculpture. The shape of the seat will symbolize the tentacles of the octopus, which portrays the meaning of health and wellbeing. The idea of representing good health is to relate with the local health unit Ora Toa located next to the park and to wish good health and prosperity to the Ngāti Toa people and the environment. This is particularly important towards the environment because it provided sustenance for the people. This will complement the koru design and the overall concept of Māori storytelling.

The seating intends to be carved wood, by a local iwi artist to portray the value of health and well-being for the people and the land through the symbolism of Te Wheke.

An excellent example of locally influenced Māori design is evident in 'Case Study 4 - Puhi Kai Iti/Cook Landing'. This project embodied Māori culture and paid tribute to historical events and the first settlers of the land. The influence of Māori culture on this project was displayed through the incorporation of large tukutuku panels, and Māori influenced sculptures laden with Māori symbolism (see fig. 37). This project proved useful in representing local iwi, portraying their story and working with them to deliver a positive design utcome.

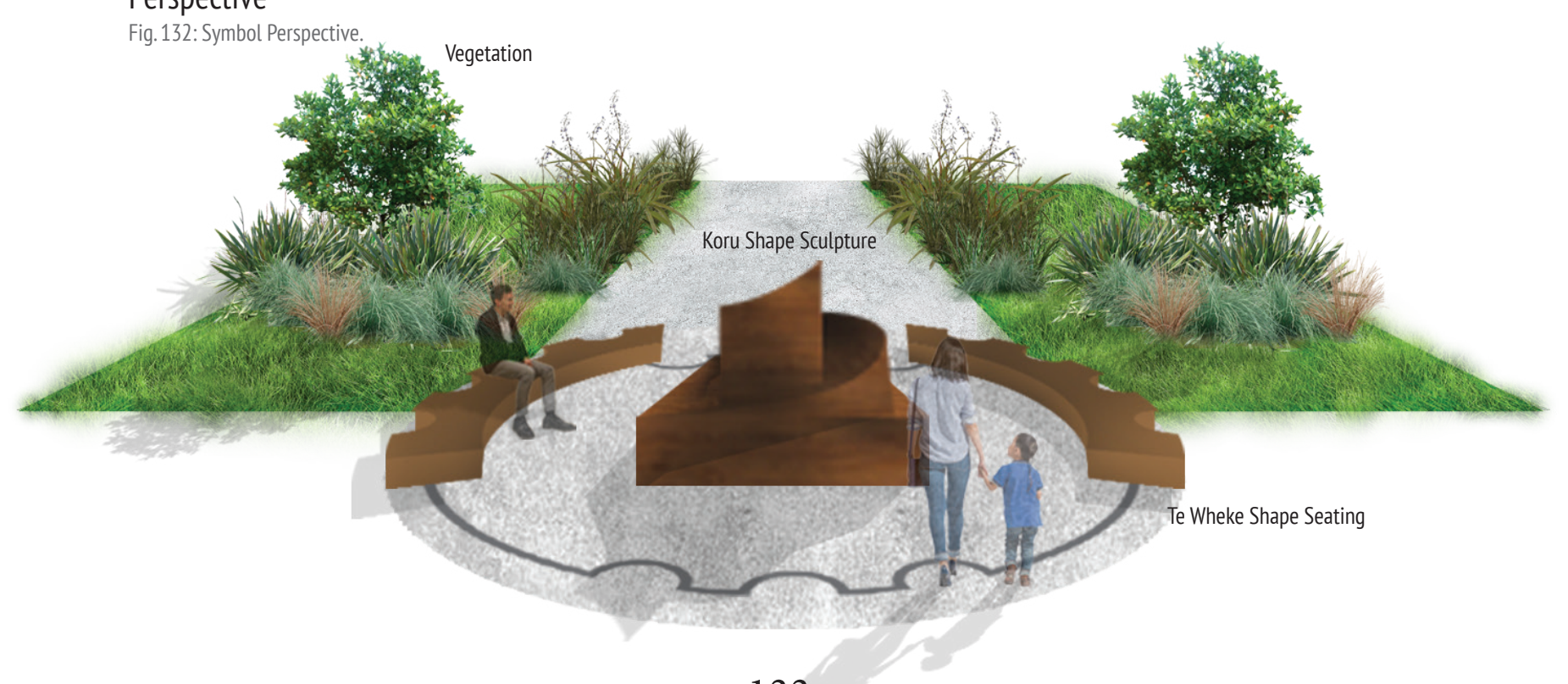

Symbol Design Plan

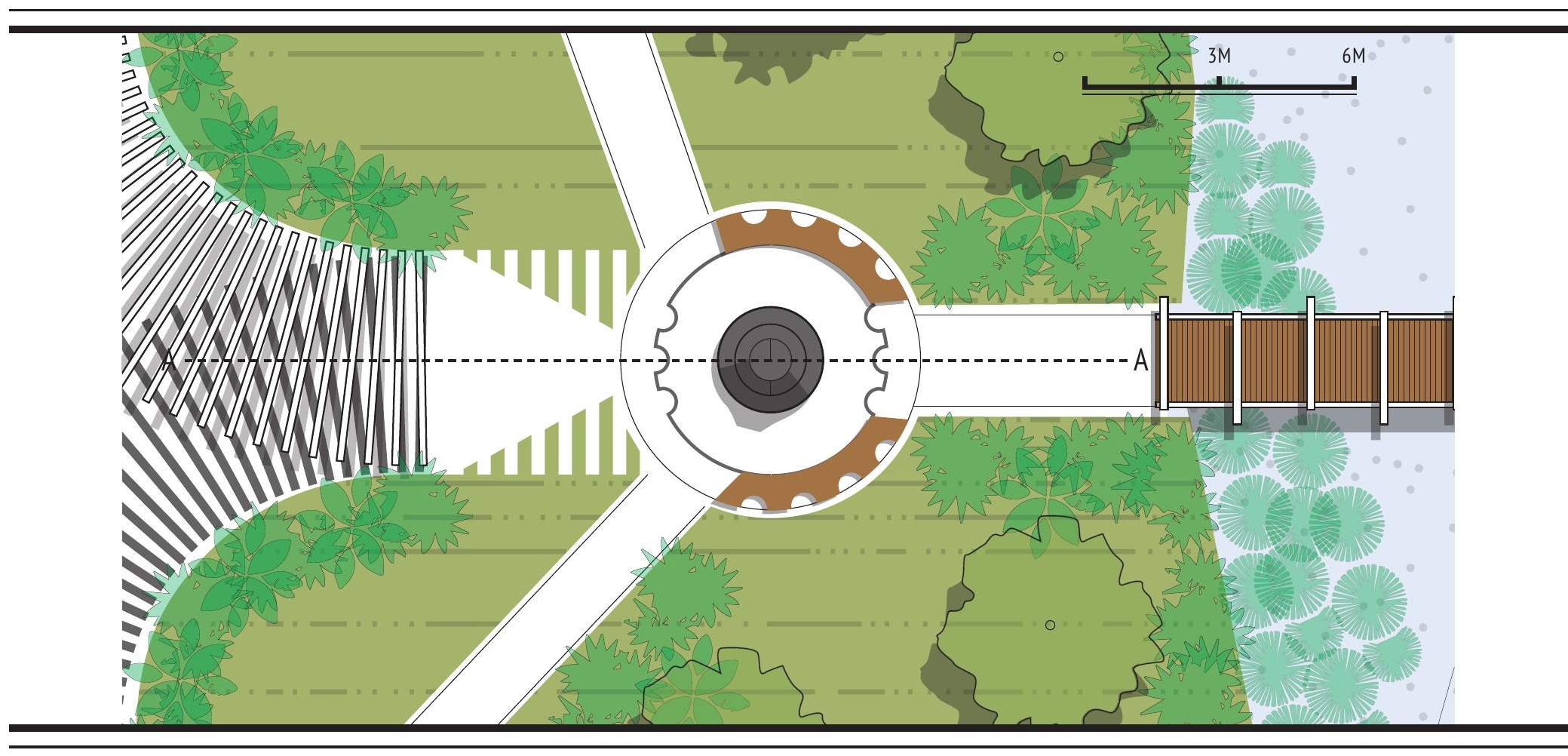




\section{BRIDGE DESIGN}

The bridge will consist of various Mangopare symbols which will be displayed throughout the design (see fig.133-135). The Mangopare represents strength, leadership and courage which will portray qualities of the Ngāti Toa chiefs and people. This symbol expresses the connection shared between the environment and the people with the intention of this

connection lasting forever.

The bridge will provide connection to and from either side of the wetland. It will

express invitation to the user and encourage

community engagement with the site. The

materials of the bridge will be made of steel

and wood. These materials will provide a safe and robust structure for the users and allow

for an aesthetically pleasing design. The bridge

will display structural shapes that depict the

symbol of the Mangopare in various ways.

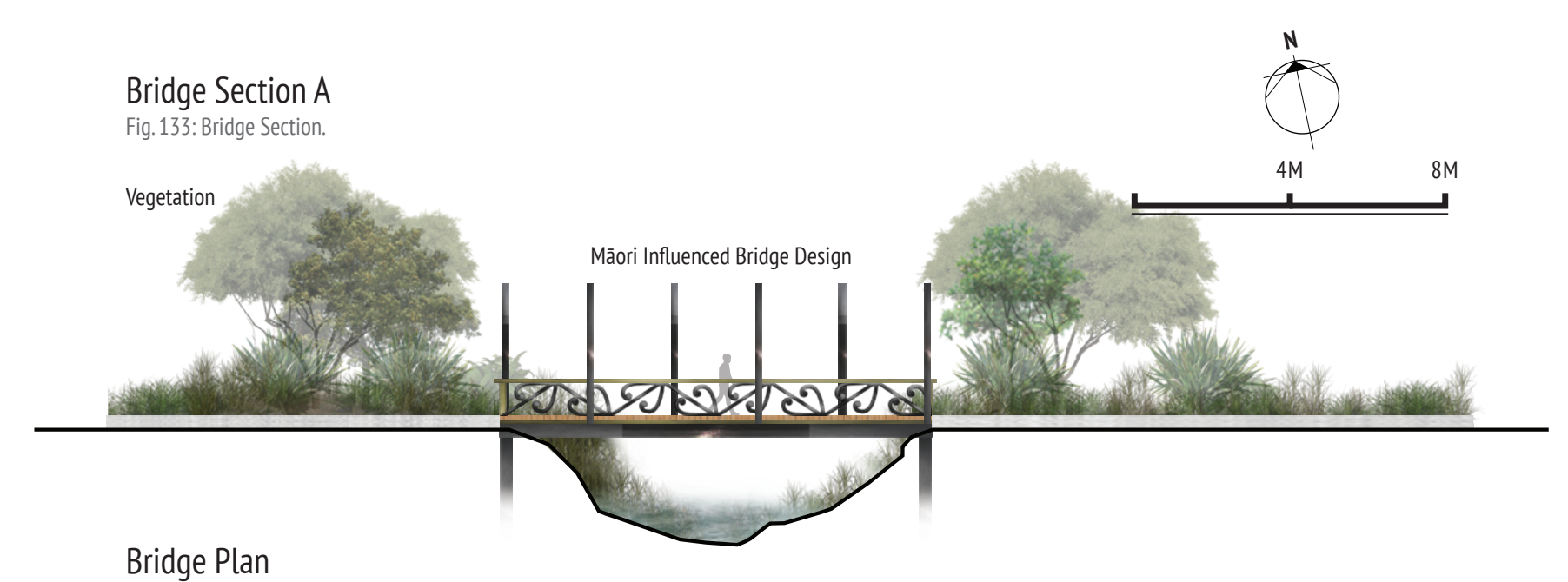

Bridge Plan

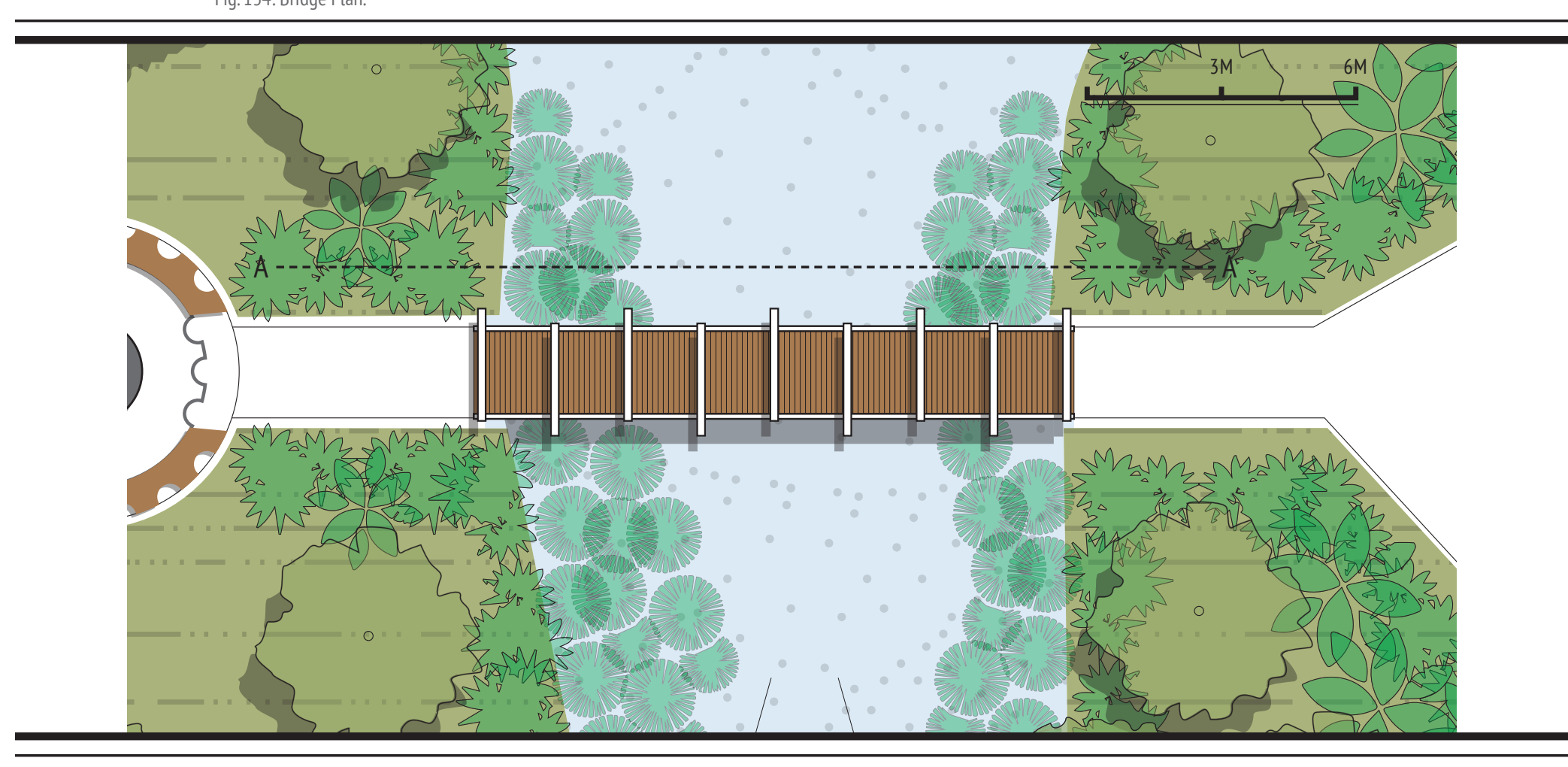

Perspective

$$
\text { Fiq.135: Bridge Perspective. }
$$

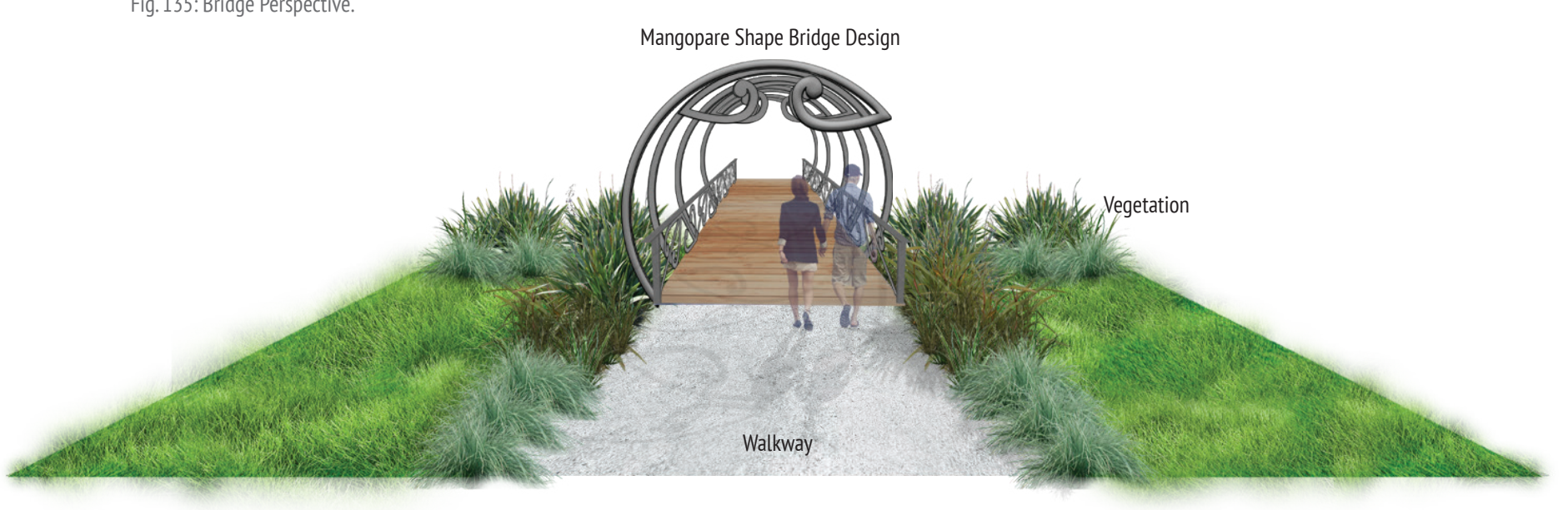




\section{PLATFORM/JETTY}

\section{Platform}

The new platform is located on the edge of the Wetland Park and will be placed adjacent to Te Hiko Street at the entrance point into

Takapūwāhia. This platform is placed there to create interest from people passing by and

also to deliver different levels of scenery to the

Wetland Park. The purpose of having a platform

that looks over the wetland is to create a sense

of intrigue and encourage engagment. This

allows the user to see the full surroundings

of the Wetland Park and gain an interest to

explore more of the place. The platform will

be level with the footpath, giving the user easy

access and opportunity for all to see the space.

This platform intends to initiate community

engagement with the place without actually

entering the site.

The platform will be made of timber slats on the surface and steel linings on the barrier to keep it structurally sound and safe for users. Creating openings to the wetland park gives a sense of invitation. The idea of welcoming is significant to Māori people as it is an

expression of aroha (love) and a sign of respect

taught by their tipuna (ancestors). The idea of welcoming someone is incorporated into Māori values such as Manaakitanga (extension of love) and Kotahitanga (oneness or unity).

\section{Jetty}

The new jetty will be placed on the edge of the wetland. This allows the user to connect with the environment through different experiences, such as being amongst the water or close enough to embrace the water and the natural surroundings.
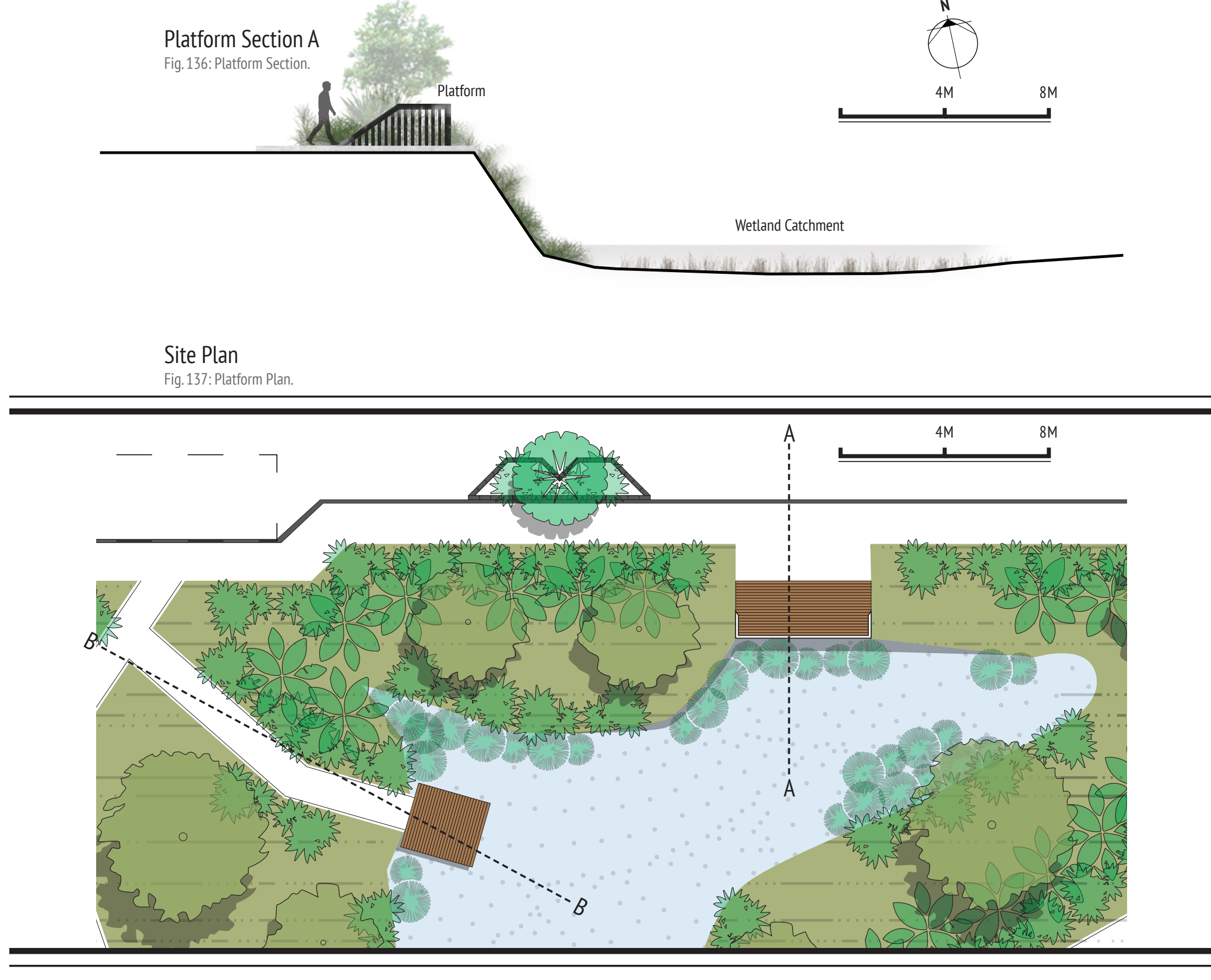

Jetty Section B Fig. 138: Jetty Section

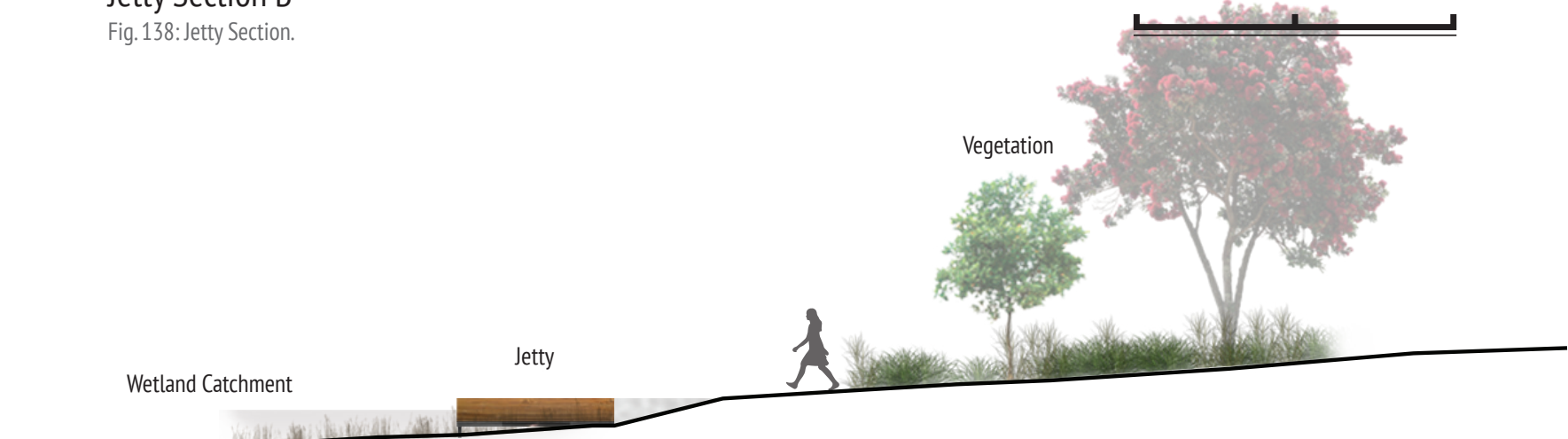


Pou Whakairo

area was influential to the Ngāti Toa people

settling in Takapūwāhia. This sculpture will

be locally carved and will correlate with the

existing sculpture located across the road that

pays tribute to another great Ngāti Toa chief, Te

Rangihaeata.

The sculpture of Te Hiko will be in vision

of Te Rangihaeata who he shared a close

relationship with. They were both influential

leaders of Ngāti Toa, and their significance is

displayed in the wharenui of the marae where

their representative pous (carved wooden

posts) are the two centrepieces. Their pous

are standing strong and holding the structure

together, as they once stood strong and held

their people together.

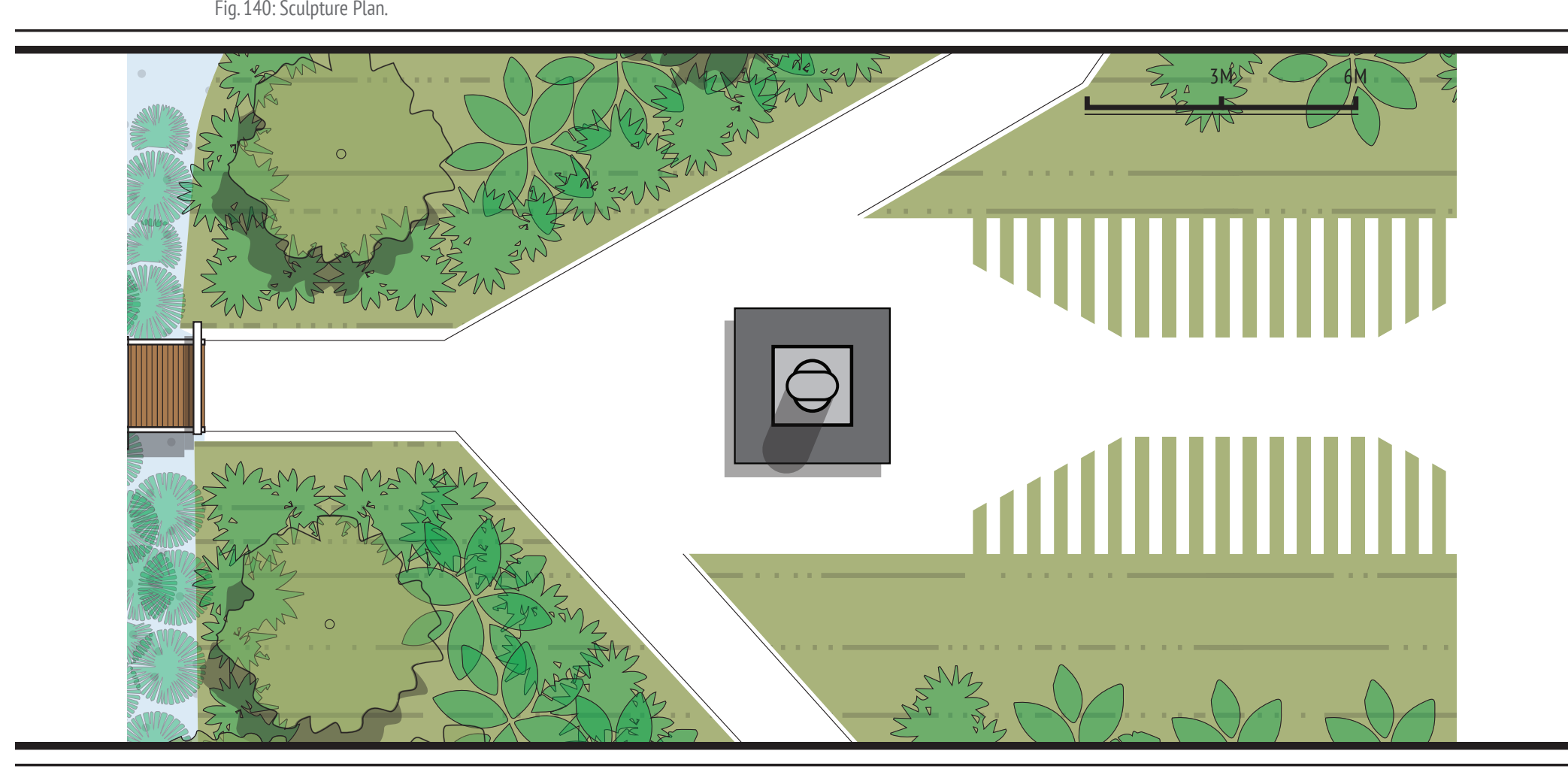

Perspective

$$
\text { Fig.141: Sculpture Perspective. }
$$

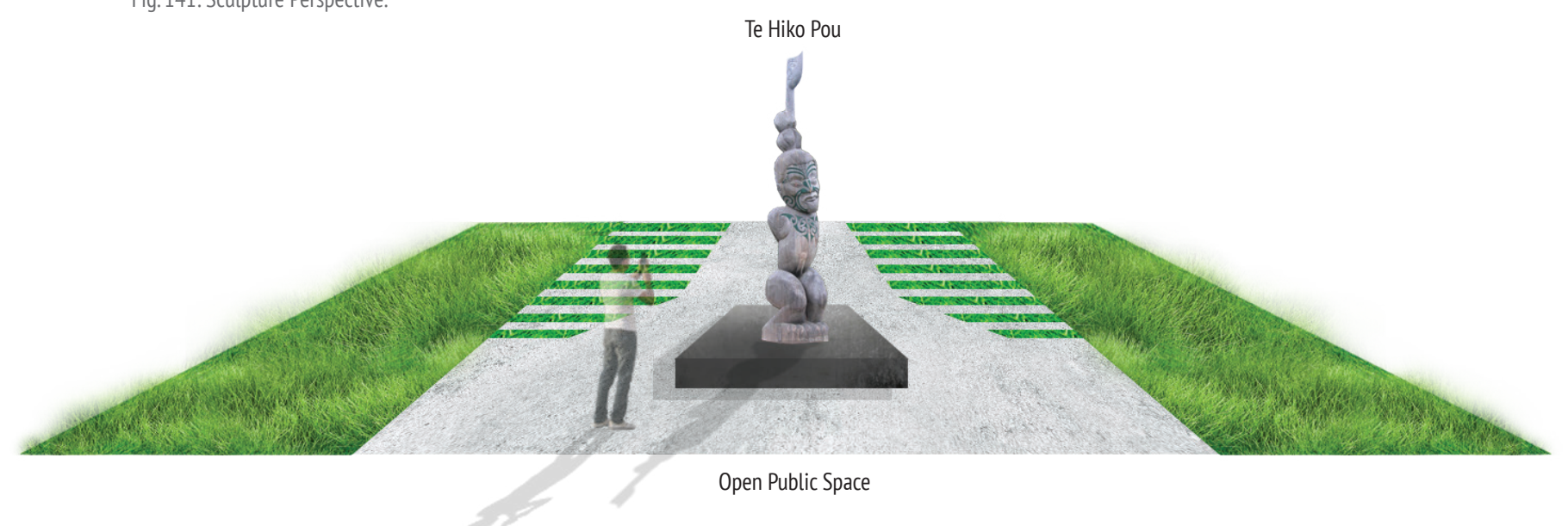




\section{CONNECTIONS/STORY}

The Wetland park intends to tell a story unique to the Ngâti Toa people. This story is portrayed through Mãori symbolism that is integrated into various design features. Every feature

located in the Wetland Park has a significant meaning and correlates with the overall story of Ngāti Toa.

The story begins with the journey of the Ngāti Toa people.

1-The journey starts with a 'welcoming'

through the pergola. The pergola intends to

create invitation which portrays the welcoming

of the Ngāti Toa people to Porirua.

2-The koru sculpture represents new life and new beginnings for the Ngäti Toa people settling in Takapūwāhia.

3-The Wheke seating surrounding the koru sculpture represents everlasting health and well-being for the Ngāti Toa people

4-The vegetation in and around the site portrays rongoā (medicinal, resourceful) which represents the abundant resources that the

\section{Porirua Harbour provided the Ngāti Toa people.}

5-The bridge design is laden with Mangopare (hammerhead shark) patterns that represents people which will last forever.

6-The final part of the journey brings you to the Pou Wakairo (Māori carved sculpture) which represents the great Ngăti Toa chief, Te Hiko. Te Hiko was influential in settlement of Ngāti Toa people at Takapūwāhia. He displayed all aspects of the journey. Such as providing for his people, caring for the well-being of his people and expressing the strength of his people through his great leadership.

Overall, this journey depiction of Māori storytelling through symbolism displays the deep understanding and values Mãori had for the land and the people.

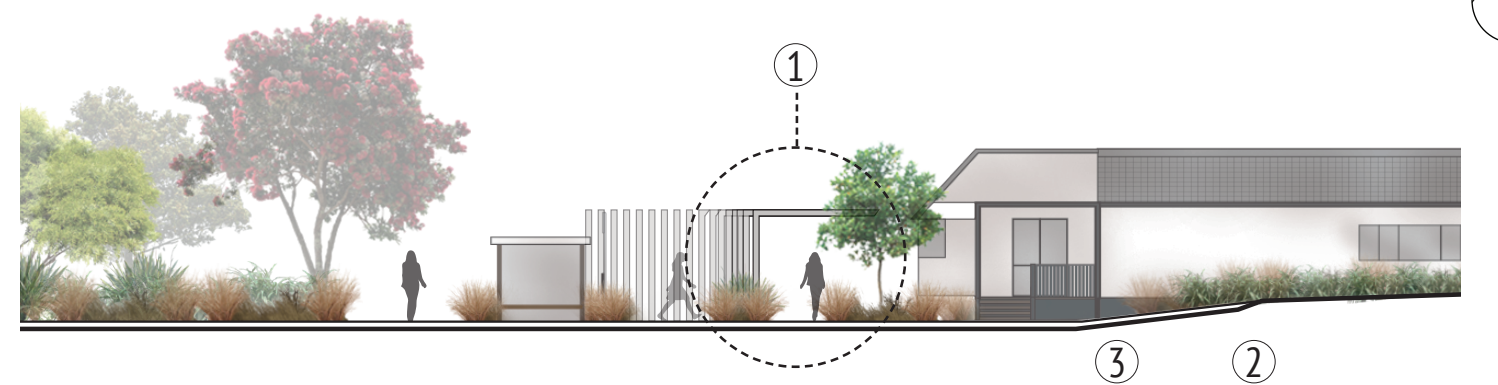

Site Plan
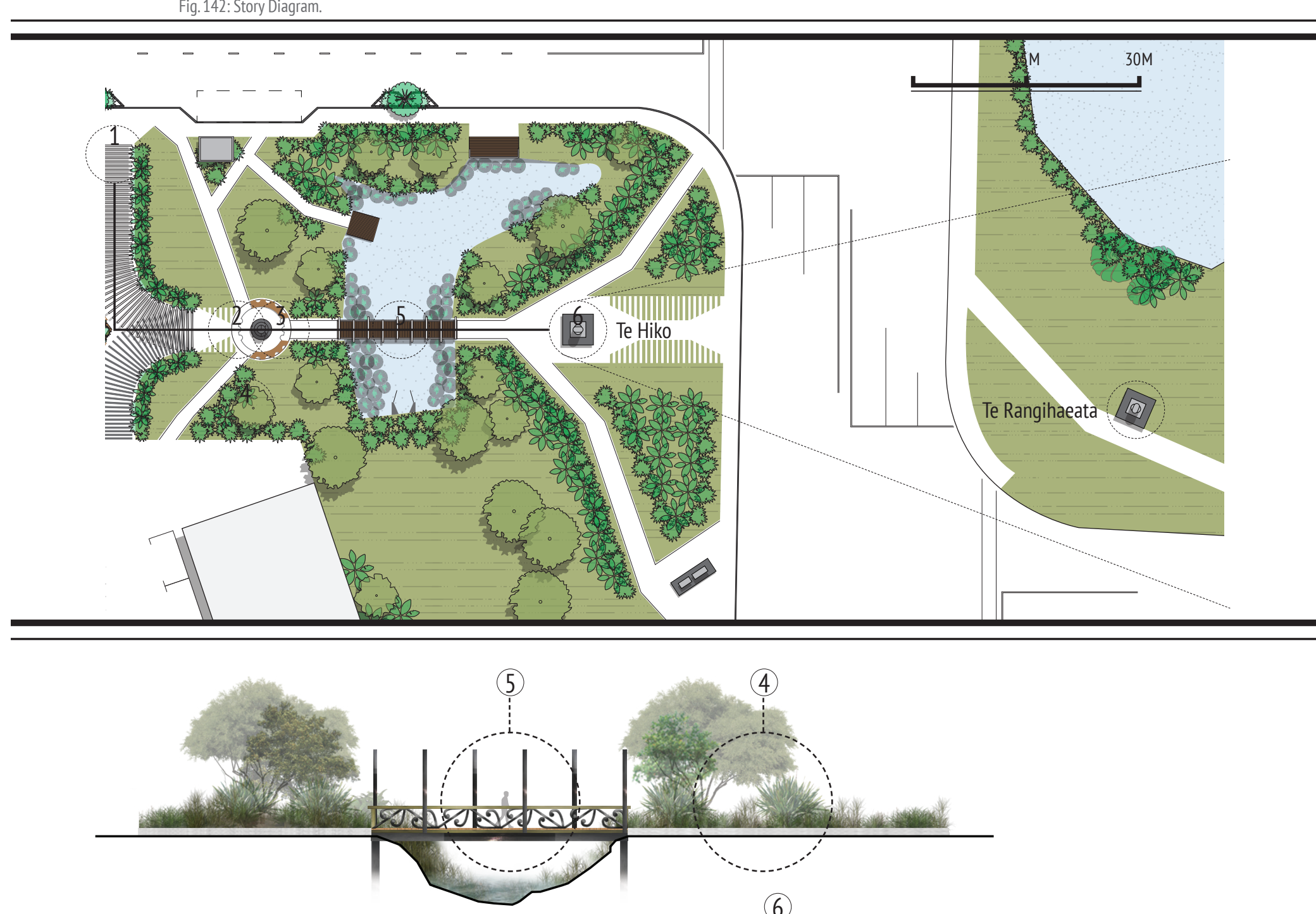

(6)

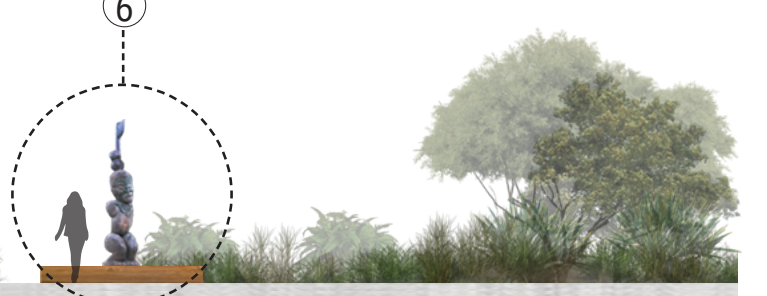


Planting Plan

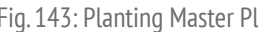

\section{an}

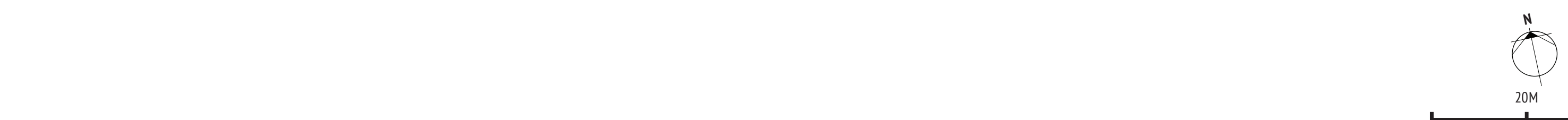

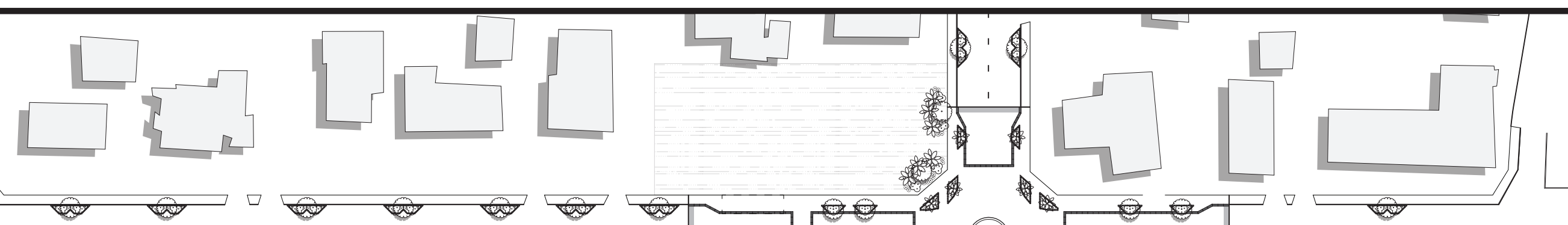

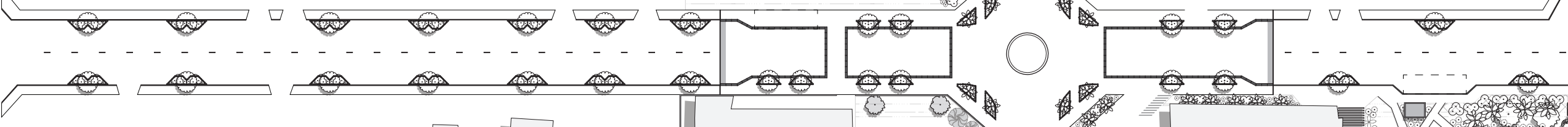
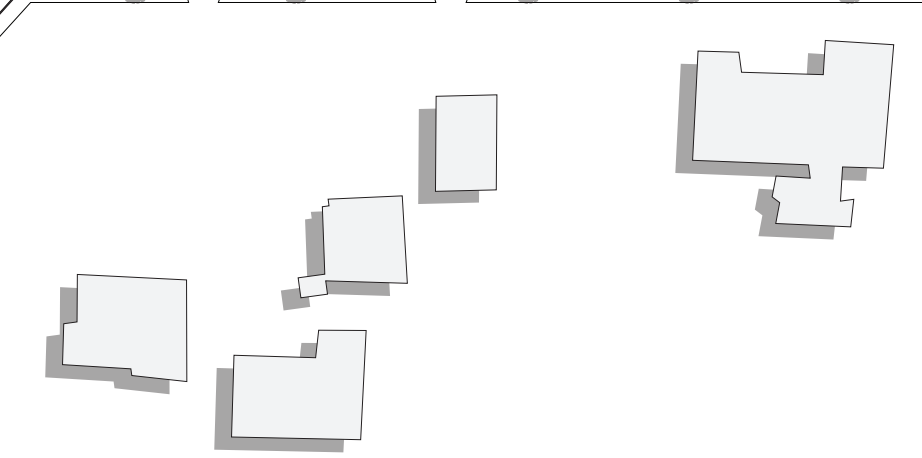

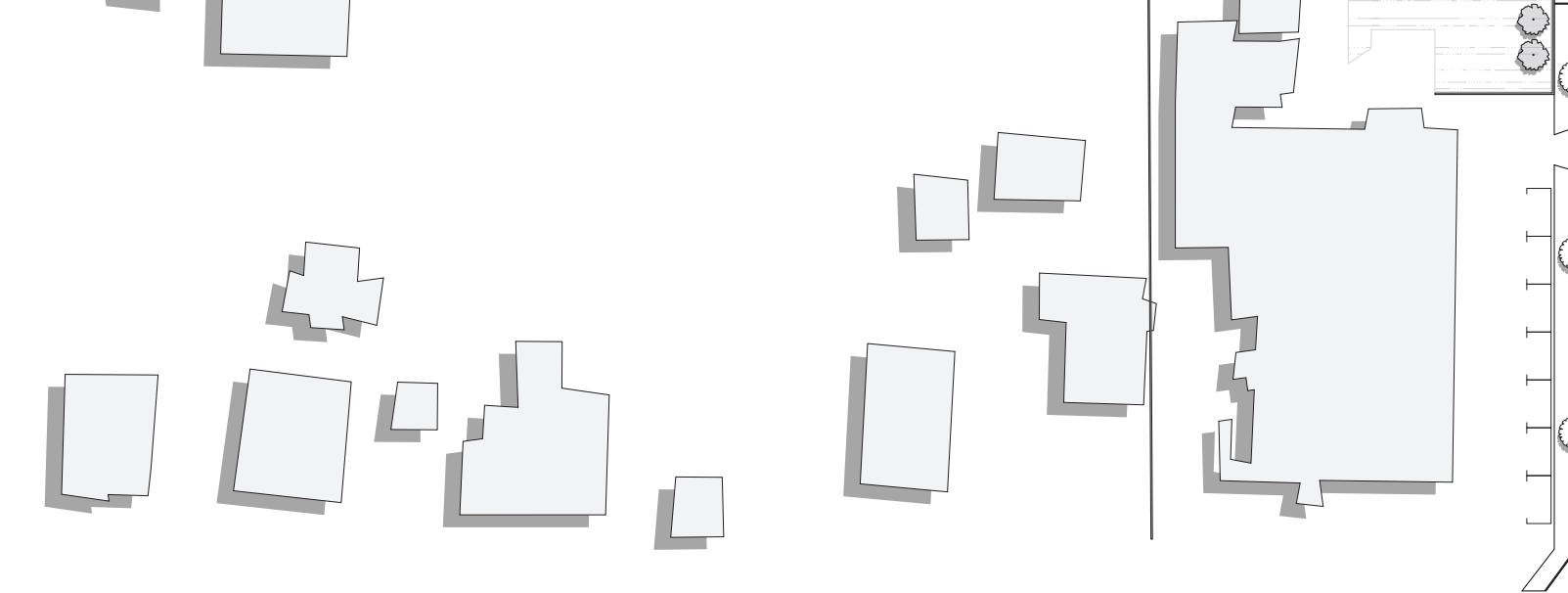

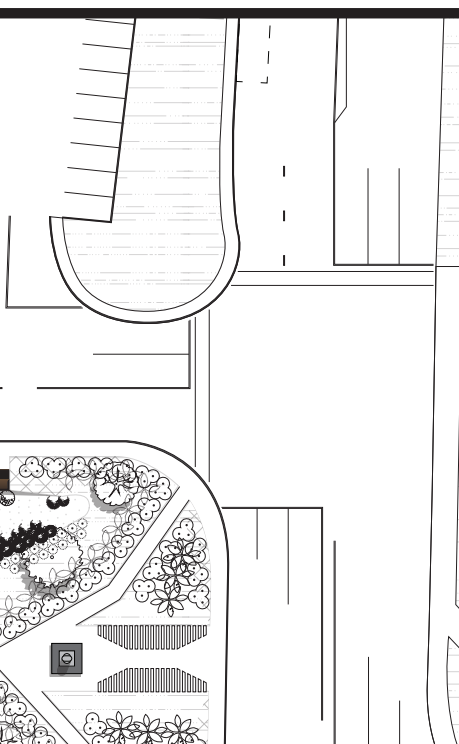

Porirua Harbour

TREES

SHRUBS/FLAX

SURFACES

D

西

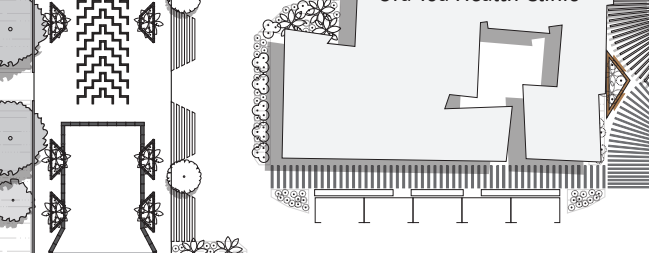

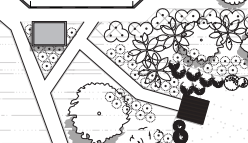

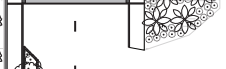

3 (Alectryon excelsus) Titoki

(Phormium tenax) Harakeke

$O$ Grass

(Fuchsia excorticata) Kōtukutuku

(Phormium cookianum) Wharariki

Water

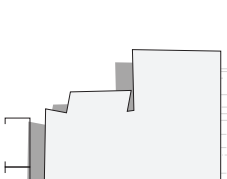

(Metrosideros excelsa) Pōhutukawa

(Pennantia corymbosa) Kaikomako

$\left.\begin{array}{lll}: & :\end{array}\right]$

(Sophora microphylla) Kowhai

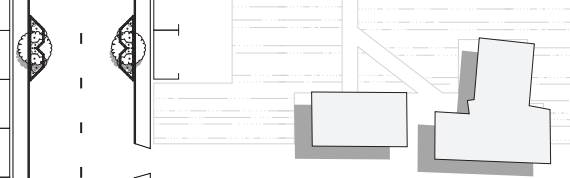

(Melicytus ramiflorus) Māhoe

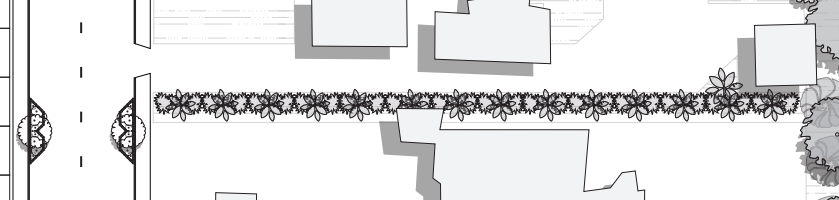

$\square$

- (Austroderia toetoe) Toetoe

(Apodasmia similis) 0i $0 \mathrm{O}$

(Lobelia angulata) Panakenake

Trees

(Typha orientalis) Raupō

(Isolepis prolifer) Isolepis

(2)

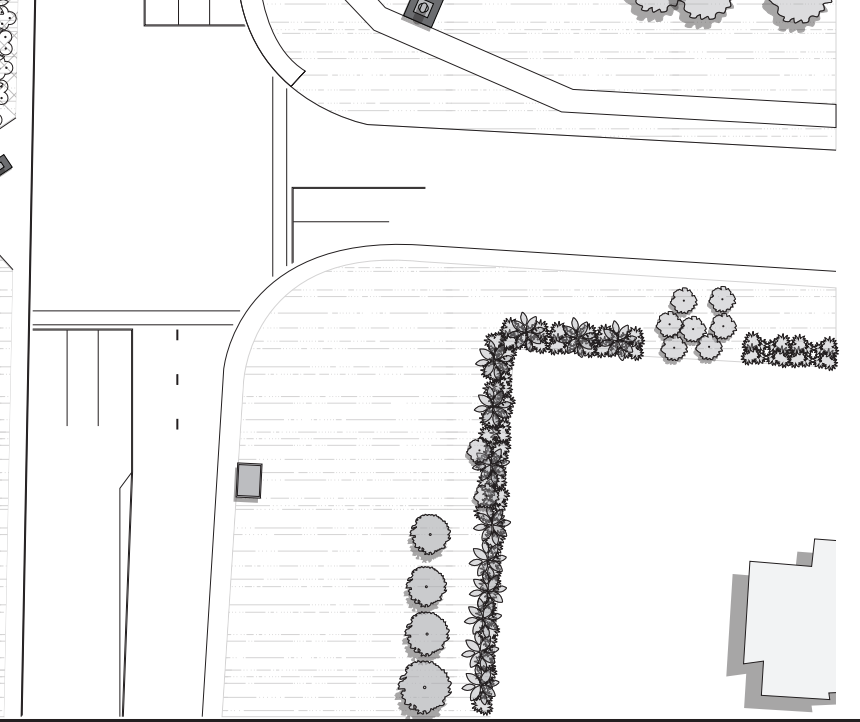

(Weinmannia racemosa) Kāmahi 


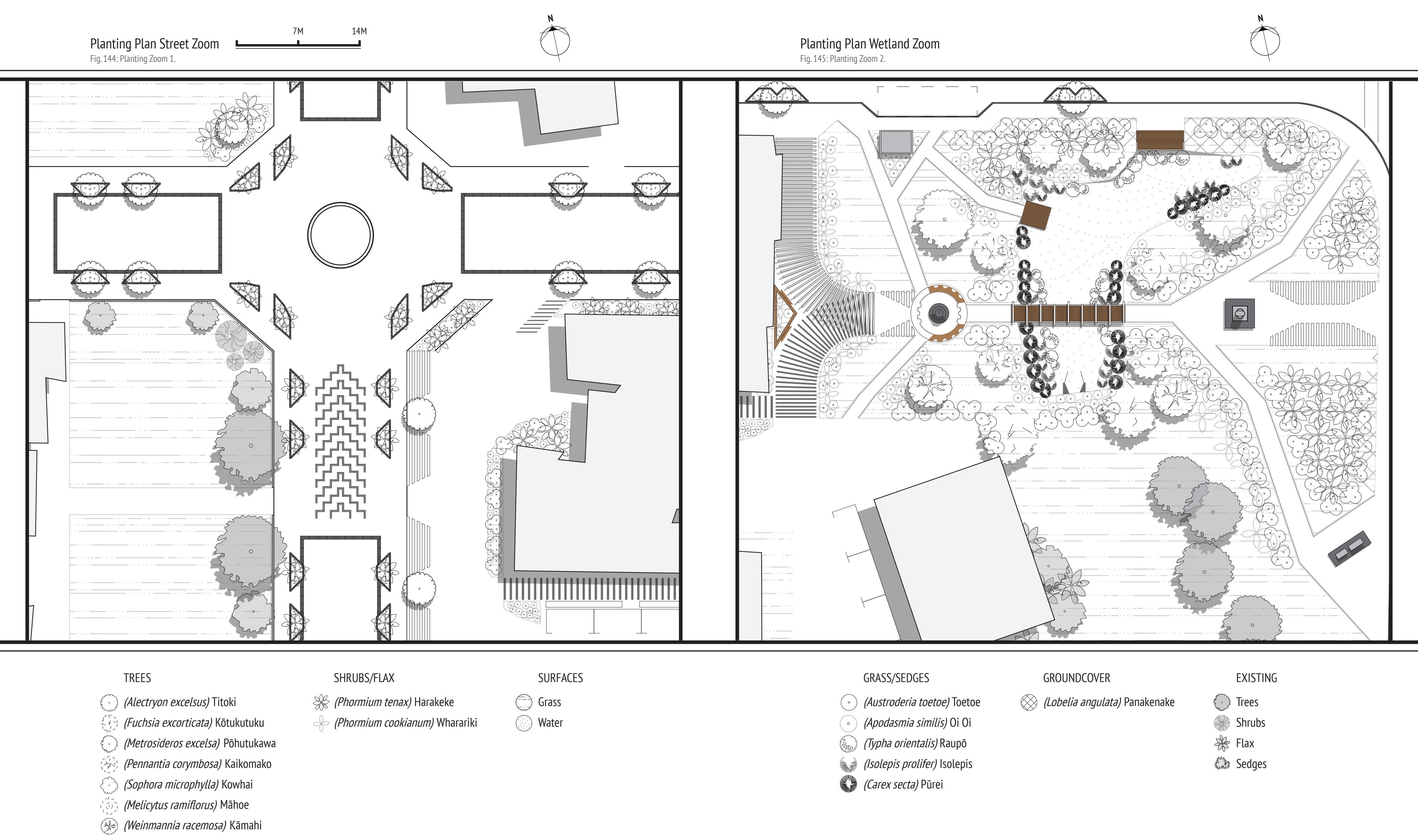




\section{Reflection}

\section{PROJECT REFLECTION}

\section{Introduction}

The intention of this design-led research

was to integrate Mãori values and landscape architecture to create connectivity between

the people and the environment and to look at how to encourage cultural and environmental awareness in communities. Exploration of the Takapūwāhia community made it apparent that there was a sense of cultural disconnect and lack of environmental awareness. This was due to the cultural shift from Māori influence on the land and people to European influence that has disconnected people from Mãori

values of appreciating and understanding the environment.

Reconnecting to Mãori Culture

The most significant part of this research was getting to understand how the values and traditions of Māori culture have in the past been applied to the environment to sustain their people. As a Māori person this project helped me to better understand $\mathrm{my}$ own culture, to reignite a lost connection and appreciation for the culture I had become estranged from and to reconnect with the Ngāti Toa iwi and Takapūwāhia community. Reconnecting with Mãori culture was not only beneficial to the project, but also beneficial to the connection I share with the community and
Community Engagement

Community engagement was a key aspect of this project. The project revolved aroun the input and output from community and Ngāti Toa iwi members, although, engaging with community and iwi members proved

challenging. These challenges were evident in attempts to organise a gathering of community members which caused minor difficulties in the project timeline. There were obstacles to setting up times to meet with the community due to unexpected events such as tangis (funerals) and other community events making it difficult to initiate community engagement. Despite the minor challenges, community engagement was eventually organised and proved to be a defining moment for the project. The community input allowed the project of designing with and for the people to really commence and develop into something unique to the community of Takapūwāhia. The community being a part of the designing, as well as the resulting design, helped to fulfil the intention of creating connection between the people and the environment.

Further case studies and research showed the benefits of community engagement in landscape design that created opportunities for communities to tell their stories through design and have a real connection with the project This connection allowed community members to work together and create

tronger relationships with each other and the environment. 


\section{Conclusion}

Portraying Māori Values Through Design

The ability to portray Māori Values and tell a story unique to Ngāti Toa through design was a challenging aspect of the project. There were difficulties in finding the right way to represent and respect Māori culture. Through community engagement, there was a suggestion for Māori symbolism to be incorporated into the project.At first, the researcher was hesitant because he had no real understanding of Māori symbolism, but after in-depth conversation with iwi members, he began to understand the significance and power Mãori symbolism has to Māori people and felt empowered to use it.

The use of Māori symbolism in design to portray Māori values became a major driving tool for the project. Researching certain symbols and what they represent enabled reconnection with Mãori culture. Through

Māori symbolism, Māori people are able to tell a story in a Māori way that is essential to their identity. Symbolism has the ability to display Māori history, traditions and values through shapes, patterns and depictions of historical creatures that are deeply meaningful to Māori people.

Through Landscape Architecture, we have the ability to portray Māori values and stories through design and our understanding of the environment. Further research and case studies of landscape projects that incorporated Māori values in design, showed evidence of cultural appreciation and community engagement. There were signs of Indigenous cultures expressing their knowledge, traditions expertise and values regarding their people

and the land in the design outcomes.

\section{Natural Systems within Infrastructure}

The challenge of landscape design is to create a design that has purpose and functionality. For example, the idea of designing for the streets of Takapūwāhia came with many considerations. There had to be consideration of environmental and community issues. These issues would range from flooding and vehicle dominant streets, to addressing the lack of connectivity between the people and the surroundings. To mitigate these issues, natural systems have to be considered in the design approach. This approach allowed analysis and understanding of the environment before designing to enhance the natural systems.

\section{PROJECT OUTCOME}

This project has been guided by Kaupapa Māori (Māori Way) methodology and how the priorities, traditions and practices of Mãori culture can influence landscape design created for, by and with Māori people.

Incorporating Kaupapa Mãori methodology has opened up opportunities for various strategies and approaches to better understand and represent Māori culture in landscape design. These opportunities have allowed community input and engagement with the project that aims to provide a space significant to the cultural heritage of Ngāti Toa, and to address current environmental issues and disconnection between the people and the land.

In order to reconnect Māori with their culture and the environment, current systems of designing need to be addressed, and change needs to be considered. This approach input cultural and environmental awareness back into struggling communities through Māor influenced design strategies and concepts. This will reflect the value and connection Māori once had with the environment and the resources the land provided Mãor with to sustain them. Once we have real understanding of the significance the environment has for the people, we will begin to appreciate the land and seek reconnection between the land and the people.
Through research and the implementation of Māori symbolism, the design has been able to display Māori values, traditions and stories. The use of symbolism is an effective way of representing Māori culture and reconnecting Māori to specific places and entities. In this design, symbols that reflect the history and traditions of Māori people and their relation to the environment. The symbols complement environmentally influenced design concepts such as Green Street design and wetland design. This system will create an environment that encourages connections between the people and the land and displays environmental and cultural appreciation.

To conclude, this thesis has developed an approach that allows landscape architecture combined with Māori culture to benefit the environment and communities. The combination of landscape architecture and Māori values can provide the blueprint for various other projects due to the intrinsic value the environment and the people have in Māori culture. This will encourage landscape architecture projects to consider and understand the surroundings in what may be a different way and to approach design with cultural and environmental awareness. Thi approach was significant in the design strategy of this project, which aimed to design with and for Māori people. 


\section{References}

AlLA. "Place of Healing." n.d. Projects: Landscape Architecture in Australia. 14 November 2019. <https://www. landscapearchitectureprojects.com/projects/2018/placeofhealing>.

Atawhai, Department of Conservation-Te Papa."Puhi Kai Iti/Cook Landing National Historic Reserve." n.d. Department of Conservation-Te Papa Atawhai. 18 November 2019.<https://www.doc.govt.nz/parks-andrecreation/places-to-go/east-coast/places/gisborne-area/cook-landing-national-reserve/>.

Auckland Council. “Kopupaka Reserve Wetland Park.” n.d. Auckland Design Manual. 14 November 2019.

Authority of New Zealand Conservation. Maori Customary use of Native Birds, Plants \& other Traditiona Materials. Interim Report and Discussion Paper. Wellington: New Zealand Conservation Authority-Te Pou Atawhai Taiao o Aotearoa, 1997.3 September 2019.

Boffa Miskell. “La Rosa Reserve Stream Daylighting.” n.d. Landezine: Landscape Architecture Platform.15 November 2019.<http://andezine.com/index.php/2016/09/la-rosa-reserve-stream-daylighting-by-boffamiskell/>.

Boffa Miskell Ltd, Graeme McIndoe Architect,Urban Designer."Porirua Suburban Character Study." June 2005.

Bratteteig, Tone and Ina Wagner."Disentangling power and decision-making in participatory design." Participatory Design Conference 2012. Roskilde: ACM New York, 2012.41-50.

Cameron, Mark, et al. "Learning through Service: The Community Design Studio." College Teaching (2001): 105-113.

Duarte,Ana, et al."Participatory Design and Participatory Research:An HCI Case Study with Young Forced Migrants." ACM Transactions on Computer-Human Interaction 25.1 (2018): 1-39.

Engagement, Tamarack Institute for Community. "Levels of community engagement." 2003. Tamarack Institute for Community Engagement. 3 September 2019. <http://www.tamarackcommunity.ca/>.

Firns, Daniel and Greg Grabasch. “Connecting People to Place." 6 March 2014. ArchitectureAU. 4 September 2019 
Giuliani, Maria Vittoria. “Theory of Attachment and Place Attachment." Bonnes, Mirilia. Psychological Theories for Environmental Issues. London: Aldershot, 2003.137-170.

Greater Wellington Council."History.” 28 November 2017. Greater Wellington Regional Council. 24 September 2019. <http://www.gw.govt.nz/history-11/>

Harmsworth, Garth. The role of Maori values in Low-impact Urban Design and Development. Discussion Paper. Palmerston North: Landscape Research NZ Ltd., n.d.

Heather."Why Street Trees?” 23 April 2015. Montavilla Tree Bud. 27 October 2019.

Hulme, Kerry. Te Whenua Te Iwi The Land and the People. Wellington, 1987.

Isthmus. “One hundred and eighty-nine steps. Freyberg Place." n.d. Isthmus. 17 November 2019.<http:// isthmus.co.nz/project/freyberg-place/>.

Jang,Won Seok."A Philosophical Evaluation of Western and Eastern Civilisations from a Whiteheadian Perspective." 2004.

Katene, Te Puoho."Toa Rangatira." Porirua, n.d.

Kruger, Max, et al. "What is participation?: emerging challenges for participatory design in globalized conditions." Interactions 26.3 (2019): 50-54

Maclean, Chris. “Wellington Places - Porirua." 9 July 2007. Te Ara - The Encyclopedia of New Zealand.24 September 2019.

Maori Culture \& Impact of West/New Zealand.n.d.11 September 2019.<https://www.arcgis.com/apps/ Cascade/index.html?appid=449c762c2b5d4d52922dee98dd7981b1>

"Māori Health, Colonization and Post-Colonization: Aotearoa New Zealand, from 1769." Journal of Northern Studies (2016): 19-43.

Menzies, Diane,Alayna Renata and Desna Whaanga-Schollum. “Connecting Eco-Systems and Belief Systems Through Regeneration and Innovation." n.d.

Ministry of Social Development. The Social Report 2016. Report. Wellington, 2016.
Nevue Ngan Associates "Stormwater Management Handbook-Implementing Green Infrastructure in Northern Kentucky Communities.” May 2009. Handbook.

New Zealand in History. “The Discovery of New Zealand" n.d. New Zealand in History. 24 September 2019. $<$ http://www.history-nz.org/discovery.html>.

\section{New Zealand Signs.n.d. 4 November 2019.}

New Zealand Statistics. “2013 Census QuickStats about a place: Elsdon-Takapuwahia.” 2013. Stats NZ.3 November 2019

Oliver, Steven. "Te Rauparaha." 1990. Te Ara - the Encyclopedia of New Zealand. 2 November 2019. <https:// teara.govt.nz/en/biographies/1t74/te-rauparaha>.

Orange, Claudia."Treaty of Waitangi." 20 June 2012. Te Ara - the Encyclopedia of New Zealand. 2 September 2019. <http://www.TeAra.govt.nz/en/treaty-of-waitangi/print>.

Pere, Rose. “Māori Health Models - Te Wheke." 18 May 2017 . Ministry of Health. 4 November 2019.

Pieters, Maarten and Stefanie Jansen. The 7 Principles of Coplete Co-creation.Amsterdam: BIS Publishers,

Pomare, Miria."Ngati Toarangatira." 8 February 2005. Te Ara - The Encyclopedia of New Zealand. 24 September 2019.

Pool, lan. “Death rates and life expectancy." 5 May 2011. Te Ara - the Encyclopedia of New Zealand. 3 September 2019. <https://teara.govt.nz/en/death-rates-and-life-expectancy/print>.

Porirua City Heritage. “Our Heritage.” n.d. Porirua City. 24 September 2019.<https://poriruacity.govt.nz/ discover-porirua/about-porirua/our-heritage/>

Porirua City.n.d. 2 November 2019.<https://profile.idnz.co.nz/porirua/about>.

Porirua Trust. "Harbour History - Porirua Harbour and Catchment History." 25 September 2019. Porirua Harbour and Catchment Community Trust. <http://www.poriruaharbourtrust.org.nz/harbour-history-2/>.

“Puhi Kai Iti / Cook Landing Site Historic Reserve Redevelopment." 2017. Boffa Miskell.16 November 2019. 


\section{Figure References}

Rangatira, Te Rūnanga 0 Toa. Te Rūnanga O Toa Rangatira. n.d. 2 September 2019.

Rangatira, Te Runanga o Toa. Takapuwahia - He Rautaki a-hapori / Takapuwahia Communtiy Strategy 2014 The Village Planning Program. Porirua, 2014.

Robinson, John. When Two Cultures Meet: The New Zealand Experience. Tross Publishing, 2012.

Saxby, Sue. "Cultural Landscapes: Enhancing the Cultural aspects of Environmental Education." n.d.

Smith, Linda Tuhiwai. Decolonizing Methodologies-Research and Indigenous Peoples. Dunedin: University of Otago Press, 1999.

Tairāwhiti, Gisbourne District Council-Te Kaunihera o Te."Puhi Kai Iti Cook Landing Site transforming with tukutuku." 20 August 2019. Gisbourne District Council-Te Kaunihera o Te Tairāwhitti. 18 November 2019.

Tau. “Tau." (1990): 4-19.

The New Zealand Curriculum. Ministry of Education/Te Tahuhu o te Matauranga. 31 July 2015.11 September 2019. <https://nzcurriculum.tki.org.nz/Principles/Community-engagement>.

Toa Rūnanga Inc. "Takapūwāhia - He Rautaki ā-hāpori ." Takapūwāhia Community Strategy 2014.2014.

Whaanga-Schollum, Desna. "Tangata Whenua; Whakaki nui a rua, Sites of Significance." Artwork Series (2013).

What is Participatory Design?n.d. 2 September 2019.<http://participateindesign.org/approach/what>.

Why Use Service Learning.n.d. 3 September 2019. 〈https://serc.carleton.edu/introgeo/service/why.html>.

Wilson, John. “History." 8 February 2005. Te Ara - the Encyclopedia of New Zealand. 2 September 2019.

<https://teara.govt.nz/en/history/print>.

\section{ALL FIGURES NOT ATTRIBUTED ARE AUTHOR'S OWN.}

Figure 25 - 26. Kopupaka wetland design - Source: "Gather and weave. Kopupaka Park." n.d. Isthmus. Image. 5 November 2019. <http://isthmus.co.nz/project/kopupaka-park/>.

Figure 27 - 30. Sister Kate's place of healing - Source:"CASE STUDY: SISTER KATE'S PLACE OF HEALING/CO DESIGNING A VISION FOR CULTURAL GROWTH.” n.d. UDLA. 10 November 2019. <https://www.udla.com.au/ sister-kates-place-of-healing>.

Figure 31 - 36. La Rosa Reserve stream and pathway connections - Source:"La Rosa Stream DaylightingAuckland's first dedicated stream daylighting project" n.d. Boffa Miskell. 8 November 2019. <https://www. boffamiskell.co.nz/project.php?v=la-rosa-stream-daylighting>.

Figure 37 - 38. Puhi Kai Iti cultural symbolism design - Source: "Stories of arrival unveiled in Gisborne." n.d. Boffa Miskell. 4 November 2019. <https://www.boffamiskell.co.nz/news-and-insights/article.php?v=storiesof-arrival-unveiled-in-gisborne>.

Figure 39 - 40. Puhi Kai Iti cultural symbolism design - Source:"Puhi Kai Iti Cook Landing Site transforming with tukutuku." n.d. Gisborne District Council. 4 November 2019. <https://www.gdc.govt.nz/puhi-kai-iti-cooklanding-site-transforming-with-tukutuku/>.

Figure 41 - 46. Freyberg Place public space, water features and cultural design - Source: "One hundred and eighty-nine steps. Freyberg Place." n.d. Isthmus. 6 November 2019. <http://isthmus.co.nz/project/freybergplace $>$. 
